
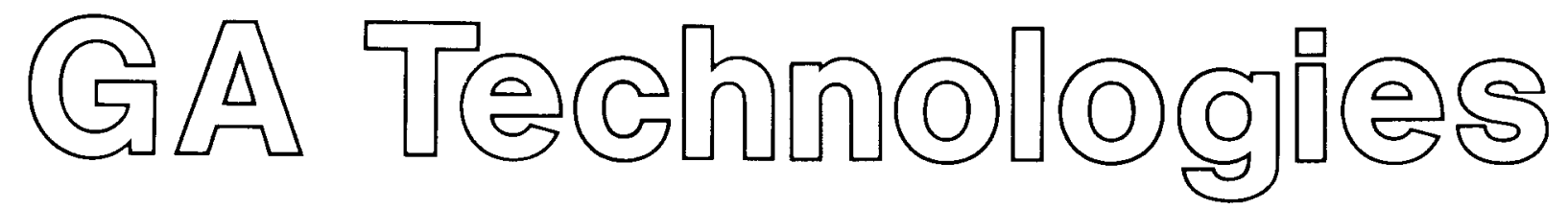

$$
\text { GA-A--18320-Vol.1 }
$$

DE86 010108

\title{
COMMERCIAL RADIOACTIVE WASTE MANAGEMENT SYSTEM FEASIBILITY WITH THE UNIVERSAL CANISTER CONCEPT
}

\author{
VOLUME I
}

by

R. P. MORISSETTE, P. E. SCHNERINGER, R. K. LANE, R. L. MOORE, and K. A. YOUNG

\author{
Prepared under \\ Contract DE-AC01-84RW00035 \\ for the Office of Civilian Radioactive Management \\ Department of Energy
}

This document is

PUBLICLY RELEASABLE GA PROJECT 3254

Lanyy \& githome DATE PUBLISHED: JANUARY 1986

Date: $11 / 22 / 2605$ 


\section{DISCLAIMER}

This report was prepared as an account of work sponsored by an agency of the United States Government. Neither the United States Government nor any agency Thereof, nor any of their employees, makes any warranty, express or implied, or assumes any legal liability or responsibility for the accuracy, completeness, or usefulness of any information, apparatus, product, or process disclosed, or represents that its use would not infringe privately owned rights. Reference herein to any specific commercial product, process, or service by trade name, trademark, manufacturer, or otherwise does not necessarily constitute or imply its endorsement, recommendation, or favoring by the United States Government or any agency thereof. The views and opinions of authors expressed herein do not necessarily state or reflect those of the United States Government or any agency thereof. 


\section{DISCLAIMER}

Portions of this document may be illegible in electronic image products. Images are produced from the best available original document. 


\begin{abstract}
A Program Research and Development Announcement (PRDA) was initiated by DOE to solicit from industry new and novel ideas for improvements in the nuclear waste management system. GA Technologies Inc. was contracted to study a system utilizing a universal canister which could be loaded at the reactor and used throughout the waste management system.
\end{abstract}

The proposed canister was developed with the objective of meeting the mission requirements with maximum flexibility and at minimum cost. Canister criteria were selected from a thorough analysis of the spent fuel inventory, and canister concepts were evaluated along with the shipping and storage casks to determine the maximum payload. Engineering analyses were performed on various cask/canister combinations. One important criterion was the interchangeability of the canisters between truck and rail cask systems.

A canister was selected which could hold three PWR intact fuel elements or up to eight consolidated PWR fuel elements. One canister could be shipped in an overweight truck cask or six in a rail cask. Economic analysis showed a cost savings of the reference system under consideration at that time.

\title{
DISCLAIMER
}

This report was prepared as an account of work sponsored by an agency of the United States Government. Neither the United States Government nor any agency thereof, nor any of their employees, makes any warranty, express or implied, or assumes any legal liability or responsibility for the accuracy, completeness, or usefulness of any information, apparatus, product, or process disclosed, or represents that its use would not infringe privately owned rights. Reference herein to any specific commercial product, process, or service by trade name, trademark, manufacturer, or otherwise does not necessarily constitute or imply its endorsement, recommendation, or favoring by the United States Government or any agency thereof. The views and opinions of authors expressed herein do not necessarily state or reflect those of the United States Government or any agency thereof. 
CONTENTS

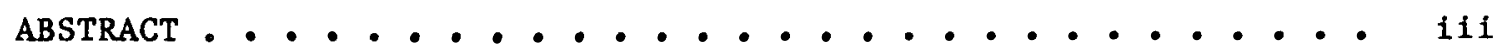

EXECUTIVE SUMMARY ..................... E-1

1. Inventory Analysis ............... E-2

2. Universal Canister System ............. E-11

3. System Economics ................ E-19

4. System Feasibility ............. E-29

5. Recommendations for Systems Analysis and Concept

Development ................ E-32

6. References .............. E-35

1. INTRODUCTION . . . . . . . . . . . . . . . . 1-1

References ........................

2. THE TIME-PHASED CHARACTERISTICS OF THE NUCLEAR WASTE

INVENTORY ..................... 2-1

2.1. Waste Acceptance Schedule Versus Burnup and Age . . . 2-4

2.1.1. Impacts Due to Age . . . . . . . . . 2-4

2.1.2. Burnup/Age Impacts . . . . . . . . . 2-8

2.2. Impact of Burnup and Age on Design Basis ....... . 2-21

2.3. Sensitivity of Burnup and Age on Design Basis . . . 2-29

2.3.1. Overall Systems Capability as Impacted by

Burnup Extensions .......... . 2-29

2.3.2. Impact on Integrated MRS Design Basis .... 2-33

2.4. Suggested Approaches to Waste Acceptance . . . . . 2-41

3. CRWM SYSTEM DEFINITION AND REQUIREMENTS . . . . . . . . 3-1

3.1. System Definition ................ 3-1

3.2. Waste Receiving and Shipping Rates........ 3-4

3.3. Waste Storage Requirements . . . . . . . . . 3-4

3.4. References .................. 3-7

4. SYSTEM FUNCTIONAL REQUIREMENTS AND DESIGN CRITERIA . . . . . . 4-1

4.1. Functional Requirements of the Universal Canister . . 4-1

4.1.1. General Requirements ........... 4-1

4.1.2. Specific Requirements .......... 4-2 
4.2. Design Criteria for the Universal Canister ...... 4-3

4.2.1. Spent Fuel Inventory ............ 4-3

4.2.2. Nuclear Criticality Safety ......... 4-6

4.2.3. Radiological Protection ......... 4-6

4.2.4. Temperature Limits........... 4-7

5. THE UNIVERSAL CANISTER SYSTEM .............. 5-1

5.1. System Description ............... 5-1

5.1.1. General .............. 5-1

5.1.2. Spent Fuel Canisters . . . . . . . . . 5-2

5.1.3. Transportation Casks .......... 5-10

5.1.4. At-Reactor Storage Cask . . . . . . . 5-21

5.1.5. Auxiliary Equipment ........ 5-23

5.2. Universal Canister Selection ....... . . 5-24

5.2.1. Universal Canister Size . . . . . . . 5-25

5.2.2. Universal Canister Shape . . . . . . 5-26

5.2.3. Universal Canister Materials ....... . 5-27

5.3. Description of Operations . . . . . . . . 5-28

5.3.1. Universal Canister Loading . . . . . . . 5-28

5.3.2. Universal Canister Transport . . . . . . 5-29

5.3.3. Universal Canister Storage . . . . . . 5-29

5.3.4. Universal Canister Burial ........ 5-30

5.4. Engineering Analysis Results ........... 5-30

5.4.1. Thermal Analysis .......... 5-30

5.4.2. Criticality Analysis .......... 5-33

5.4.3. Shielding Analysis.......... 5-34

5.4.4. Structural analysis ......... . 5-38

5.5. Cost Estimates ... . . . . . . . . . 5-40

5.5.1. General Cost Assumptions ........ 5-41

5.5.2. Cost Estimates ........... 5-41

5.6. References ............. 5- . . . . . . .

6. SYSTEM ECONOMICS .................. 6-

6.1. WADCOM-MF Input Assumptions ............ 6-1

6.1.1. Dry At-Reactor Storage (DRS) ........ 6-1

6.1.2. Transportation .......... 6- $6-4$ 
6.1.3. Fuel Consolidation ........... 6-4

6.1.4. Integrated MRS .............. 6-4

6.1.5. Repositories ............. 6-5

6.2. Results of Economic Analysis ... . . . . . . 6-5

6.2.1. Comparison of PRDA Reference System to GA

Reference System............ 6-5

6.2.2. Comparing the GA Reference System with the GA Integrated MRS System ......... 6-8

6.2.3. Comparison of the PRDA Reference System with the GA Alternate System .... . . . 6-10

6.3. Discounted Cash Flows .............. 6-10

6.4. References .................. 6- 6- . . . 1

7. SYSTEM FEASIBILITY . . . . . . . . . . . . $7-1$

7.1. Technical Feasibility .............. 7-1

7.1.1. Flexibility in Storage and Transportation . . 7-1

7.1.2. Flexiblity of Universal Canister for Waste
Packaging ................ 7-6

7.1.3. Concept Maturity ............ . 7-17

7.2. Licensing Feasibility ............... $7-21$

7.2.1. Transport from the Reactor ........ 7-21

7.2.2. Storage at an MRS Facility......... 7-22

7.2.3. Transport from the MRS Facility ....... 7-22

7.2.4. Burial at the Repository .......... 7-22

7.3. Environmental Feasiblity ............. 7-23

7.3.1. Resource Commitments .......... . 7-23

7.3.2. Nonradiological Effluents ........ 7-24

7.3.3. Radiological Effects .......... 7-24

7.3.4. Ecological Effects ........... . 7-24

7.4. Socioeconomic Feasiblity ............ 7-25

7.5. Reference ................. 7-25

8. EVALUATION OF THE SELF-SHIELdEd WASTE PACKAGE . . . . . . 8-1

8.1. Bases for the USSWP Evaluation . . . . . . . . 8-2

8.2. Technical Review of USSWP ............ . 8-2

8.2.1. Shielding Analysis Results......... 8-3

8.2.2. Thermal Analysis Review .. . . . . . 8-6

8.2.3. Inventory Handling Capability ....... 8-8 
8.3. Licensing of USSWP .............. 8-10

8.3.1. Storage and Transportation ........ 8-10

8.3.2. Disposal ................8-11

8.4. USSWP Cost Estimate ................ 8-11

8.4.1. Cost of Unmodified USSWP . . . . . . . 8-12

8.4.2. Adjustment for Neutron Shielding . . . . . 8-15

8.5. Total System Costs ............. 8-17

8.5.1. Cost Element Comparison ......... 8-17

8.5.2. MRS Cost Estimate ........... 8-20

8.6. REFERENCES ................... . . 8- . . . . . . .

APPENDIX A: INVENTORY ANALYSIS METHODOLOGY AND DETAIL RESULTS • A A-1

APPENDIX B: RADIOACTIVE WASTE PACKAGING AND HANDLING SYSTEM

FUNCTIONAL REQUIREMENTS AND DESIGN CRITERIA . . . . B-1

APPENDIX C: DESIGN ANALYSES ................

APPENDIX D: ECONOMIC ANALYSIS ................ D-1

\section{FIGURES}

1. Reference fuel burnup distributions: 1985 versus 2020 . E-4

2. Age distribution of spent fuel transfers for discharges through 2020 ................ E-5

3. Heat load distribution for reference fuel burnup . . . . E-7

4. Heat load distribution for extended fuel burnup . . . E-9

5. Universal canister waste package configurations for multimedia repository application . . . . . . . . E-10

6. Neutron source for fuel discharged in 2010 ....... E-12

7. Principal canister design ............ E-14

8. Arrangement of six principal design canisters in a rall shipping cask, a storage cask, or a storage module . . . E-16

9. Transportation cask requirements for the reference CRWM system with tuff/granite repositories . . . . . . . E-24

10. Comparisonn of transportation cask requirements between the reference CRWM system with tuff/granite repositories and the integrated MRS system ........... E-26

11. Ra1l cask requirements for the integrated MRS system with tuff/granite repositories . . . . . . . . . E-27 
FIGURES (Continued)

12. Deployment schedule for integrated MRS concrete storage casks . . . . . . . . . . . . . . . . E-28

13. Deployment schedule for at-reactor storage casks . . . E-30

2.1-1. Age of fuel into repository . . . . . . . . . . 2-7

2.1-2. Heat load into repository for backup MRS case with 8-year repository delay . . . . . . . . . . . . 2-9

2.1-3. Burnup level for fuel discharged up to indicated years . 2-15

2.1-4. Burnup level for fuel discharged in year 1985 . . . . 2-16

2.1-5. Burnup level for fuel discharged in year 1990 . . . . 2-17

2.1-6. Burnup level for fuel discharged in year 2010 . . . . 2-18

2.1-7. Neutron source distribution for reference fuel burnup . 2-19

2.1-8. Heat load distribution for reference fuel burnup . . . . 2-20

2.2-1. Fuel burnup distributions: 1985 versus 2020 . . . . 2-23

2.2-2. Age distributon of spent fuel transfers for discharges

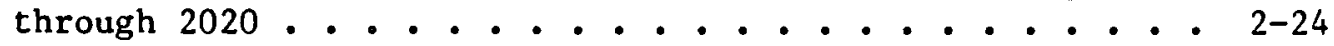

2.2-3. Enrichment of fuel discharged up to 2020 . . . . . 2-25

2.2-4. Gamma source distribution for reference fuel burnup . . 2-26

2.3-1. PWR burnup uncertainties predicted for discharges through 2020 . . . . . . . . . . . . . . 2-31

2.3-2. Mean heat load versus year of emplacement . . . . . 2-32

2.3-3. Heat load distribution for extended fuel burnup . . . . 2-34

2.3-4. Neutron source for fuel discharged in 2010 . . . . . 2-36

2.3-5. Heat load for fuel discharged in 2010; reference versus extended burnup ............... 2-37

2.4-1. Gamma source versus burnup/age ratio . . . . . . . 2-43

3.1-1. Reference CRWM system . . . . . . . . . . . . 3-2

3.1-2. Integrated MRS system ............... 3-3

5.1-1. Principal canister design . . . . . . . . . . 5-3

5.1-2. Principal canister for GA packaging and handling

5.1-3. Alternate canister design (rail canister) with 19 PWR
spent fuel assemblies . . . . . . . . . . . . .

5.1-4. Plan view of alternate canister design with 19 PWR spent fuel assemblies ......... . . . . . 5-9

5.1-5. Principal canister design in truck shipping cask.... . 5-13 
FIGURES (Continued)

5.1-6. Alternate canister design in rail shipping cask . . . 5-15

5.1-7. Arrangement of six principal design canisters in a rail shipping cask, a storage cask, or a storage module . . . 5-16

5.1-8. Rail cask's inside diameter increased to hold seven 19-1n.-i.d. canisters . . . . . . . . . . 5-20

5.1-9. Typical at-reactor storage cask . . . . . . . . 5-22

5.4-1. Multiplication factor $\left(\mathrm{K}_{\text {eff }}\right)$ versus enrichment . . . . 5-35

5.4-2. Cross section of rail shipping cask . . . . . . . . 5-37

7.1-1. Universal canister waste package configurations for multimedia repository application .......... . 7-11

7.1-2. Salt repository waste package configuration . . . . . 7-12

7.1-3. Basalt repository waste package configurations . . . . 7-13

7.1-4. Tuff or granite repository waste package configuration . 7-14

8.2-1. Heat load distribution for reference fuel burnup . . . . 8-7

8.2-2. Neutron source distribution for reference fuel burnup . . 8-9

8.4-1. Single-parameter sensitivity for cask unit cost versus system cost for USSWP system . . . . . . . . 8-16

8.5-1. Sensitivity of USSWP unit cost . . . . . . . . . 8-19

8.5-2. MRS operating cost comparisons ............ 8-21

8.5-3. MRS capital cost comparisons . . . . . . . . . 8-24

TABLES

1. Radioactive waste management systems costs (million 1985 dollars) .................... E-21

2. Radioactive waste management systems costs (mil1ion 1985 dollars undiscounted) . . . . . . . . . . . E E-22

2.1-1. Reference case waste acceptance schedule . . . . . . 2-5

2.1-2. Alternate case waste acceptance schedule . . . . . . 2-6

2.1-3. Spent fuel burnups and ages at emplacement reference case - MTUS ............... 2- 2-10

2.3-1. Rail cask nominal payload capability comparison . . . 2-39

2.3-2. Transport cask fuel handling capability comparison for typical annual transfers from MRS to repository after about 2015 ...................... 2- 240 
TABLES (Continued)

3.2-1. At-reactor dry storage inventory for reference case

(MTU) .................... 3-5

3.2-2. At-reactor dry storage inventory for the integrated MRS system (MTU) .............. 3-6

4.2-1. Comparisonn of spent fuel nuclear characteristics: GA design criteria versus nominal criteria ...... . 4-5

5.1-1. Truck shipping cask ............. 5-14

5.1-2. Rail shipping cask ............. 5-18

5.1-3. Cask/cantster weight summary ............ 5-19

5.4-1. Maximum predicted cladding temperatures for canistered spent fuel in a rail transportation cask ...... 5-31

5.5-1. Principal canister design cost summary . . . . . . 5-42

5.5-2. Alternate canister design (ra11) cost summary . . . . . 5-44

5.5-3. Transport and storage cask cost summary .... . . . 5-45

5.5-4. Transport and storage casks: design and certification costs............... 5- . . . . . . . . 46

6.1-1. Major differences: GA cases versus PRDA reference case ................. . . 6-2

6.2-1. Radiaoctive waste management system costs . . . . . 6-6

6.2-2. Cost savings from GA systems . . . . . . . . 6 6-7

6.2-3. PRDA reference system basalt X granite ........ 6-11

6.2-4. PRDA reference system salt X granite . . . . . . 6-12

6.2-5. PRDA reference system tuff X granite ........ . 6-13

6.2-6. GA reference system basalt X granite ........ 6-14

6.2-7. GA reference system salt X granite . . . . . . . 6-15

6.2-8. GA reference system tuff $X$ granite . . . . . . . 6-16

6.2-9. GA integrated MRS basalt X granite ......... . 6-17

6.2-10. GA integrated MRS salt X granite .......... 6-18

6.2-11. GA integrated MRS tuff X granite ......... 6-19

6.3-1. Radioactive waste management systems costs . . . . 6-20

6.3-2. PRDA reference cases discounted cost analysis basalt X
granite repositories . . . . . . . . . . . 6-22

6.3-3. PRDA reference cases discounted cost analysis salt X
granite repositories . . . . . . . . . . 6-23 
TABLES (Continued)

6.3-4. PRDA reference cases discounted cost analysis tuff $X$ granite repositories ............ . 6-24

6.3-5. GA reference cases discounted cost analsis basalt $X$ granite repositories ............ 6- 6-25

6.3-6. GA reference cases discounted cost analysis salt $\mathrm{X}$ granite repositories . . . . . . . . 6- 6- 26

6.3-7. GA reference cases discounted cost analysis tuff $X$ granite repositories . . . . . . . . . . 6-27

6.3-8. GA integrated MRS case discounted cost analysis basalt $\mathrm{X}$ granite repositories . . . . . . . . . 6-28

6.3-9. GA integrated MRS case discounted cost analysis salt $X$ granite repositories . . . . . . . . . . 6-29

6.3-10. GA integrated MRS case discounted cost analysis tuff $X$ granite repositories . . . . . . . . . 6 6-30

7.1-1. Waste package compatibility - fixed design basis . . - 7-8

7.1-2. Repository package designs ........... . 7-10

7.1-3. Package heat load illustration - tuff/granite . . . . 7-16

8.2-1. Universal self-shielded waste package dose calculation results................ 8-4

8.4-1. Westinghouse cost estimate for USSWP for introduction at the MRS .................... 8-13

8.4-2. Universal self-shielded waste package cask cost summary - SSP-9 design ........... . 8-14

8.5-1. PRDA alternate case total system cost comparisons . . . 8-18 8.5-2. MRS capital cost ................ 8-23 
The Department of Energy (DOE's) Draft Mission Plan for the Civilian Radioactive Waste Management Program issued in April 1984 addresses the concern that the Commercial Radioactive Waste Management (CRWM) system could potentially evolve into a multi-element system resulting in a number of separate packaging and handling operations. Because of this concern, a Program Research and Development Announcement (PRDA) was initiated to solicit from industry new and novel ideas for improvements in the CRWM system. As a result of the PRDA, GA Technologies Inc. (GA) was contracted to study a system utilizing a universal canister which could be loaded with spent fuel in the reactor storage pools prior to at-reactor dry storage or shipment to interim storage, monitored retrievable storage, or the repository.

The objective of this study was to develop a system which would allow DOE to meet the mission requirements of the Nuclear Waste Policy Act with maximum flexibility and minimum cost. The proposed concept would provide for handing, shipping, and storling of spent fuel such that packaging and handling would be minimized while standardization of interfaces and equipment would be maximized. Because of uncertainties in the implementation of the CRWM system, the proposed concept should provide the flexibility necessary to accommodate future changes in the system while reducing the risks involved in handling high-level radioactive waste.

The proposed universal canister concept was developed with these objectives in mind. First, the canister criteria were selected after extensive analysis of current and future spent fuel inventories to ensure that the proposed system could handle up to $95 \%$ of this inventory within the design capacity of both the canister and associated shipping 
and storage equipment. Heat load and radiation source terms required for design were determined based on expected age and burnup of the spent fuel. The age was based on DOE's draft mission plan waste acceptance schedule, (Ref. 1)。 The canister criteria determined in this study, however, would be different if major changes were necessary in the DOE waste acceptance schedule.

Second, canister concepts were evaluated along with the shipping and storage casks to determine the maximum payload within regulatory and operational limits. Engineering analyses were performed on various canister/cask combinations to determine fuel temperatures and shielding requirements. To maximize the flexibility of the system, exchangeability of canisters between truck and rail cask was one of the criteria used in the development of the canister.

The following provides a summary of the GA PRDA program study and presents the major findings and conclusions which resulted from the study.

\section{INVENTORY ANALYSIS}

An important subtask on the PRDA Systems Studies has been to carry out an analysis of the time-phased statistical distribution of those spent fuel inventory characteristics which could limit the size of transport and storage casks, or disposal packages. The inventory characteristics of burnup and decay age define the heat load and the gamma and neutron shielding source terms. The inventory analysis also included criticality calculations based on a number of assumed unburned fissile enrichments for several different basket arrays and fuel assembly pitches.

The primary goal of this task was to define the time-phased inventory distribution, as a function of heat load, neutron and gamma source strength, and fissile enrichment in order to define a maximum payload, 
or inventory handling capability, of a universal canister system design capable of handling essentially all of the total inventory of lightwater reactor (LWR) fuel discharged through the year 2020. A goal of $\geq 95 \%$ was selected to ensure that the universal canister would operate with the equipment and facilities developed for the CRWM system during their design lifetime. Since neutron source strength is strongly related to burnup whereas heat load and gamma source strength are dependent on the spent fuel age, criteria were selected which would encompass $95 \%$ of the high-burnup fuel as well as the low-age fuel.

Setting the canister size at 176 in. provided sufficient length to encompass over $95 \%$ of the fuel. Only a small percentage of the fuel exceeds this length.

The inventory analysis has been based on the use of simple equations to fit a set of actual calculated data, based on ORIGEN computer runs, of neutron and gamma source strength and heat load as a combined function of the burnup and decay age. These fits, which are accurate to within about $10 \%$ for decay ages of 2 to about 20 years, were coupled to the MTU burnup and age distributions estimated from reactor discharge data and DOE acceptance schedule(s) (Refs. 1 and 2).

The important conclusions and recommended strategies that have resulted from these inventory analyses are as follows:

1. A design basis equivalent to that proposed for the universal canister system will be required for whatever system components are ultimately chosen to transport, store, and dispose of the LWR spent fuel if a high inventory handling capability is to be achieved. A capability for handling, as consolidated fuel, the equivalent of fuel burned to 40,000 MWd/MTU and decayed no more than 7 years is required in order to achieve a $>95 \%$ inventory handling capability based on the fuel flows specified by Ref. 1. Figures 1 and 2 show the burnup and age 


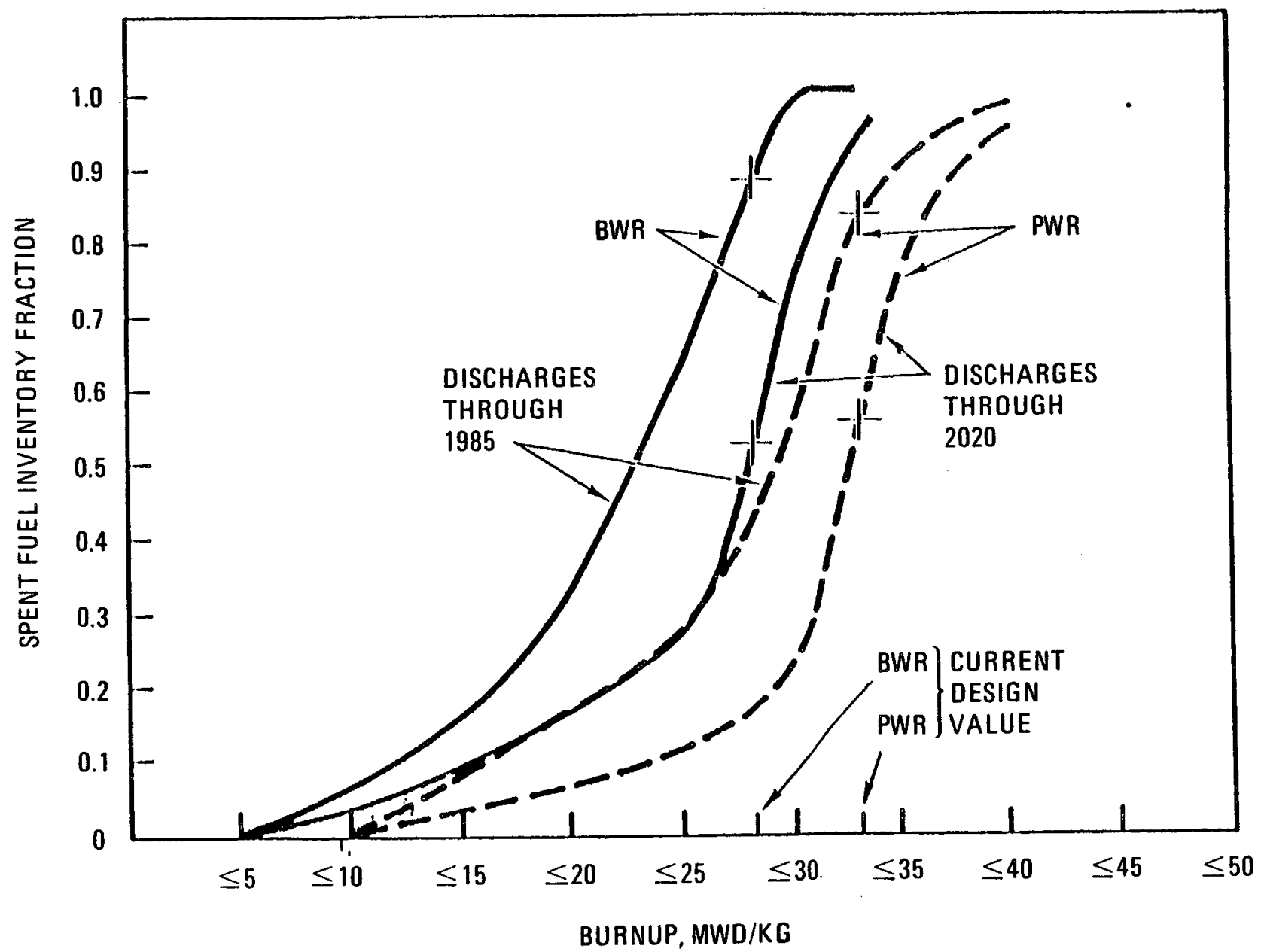

Fig. 1. Reference fuel burnup distributions: 1985 versus 2020 


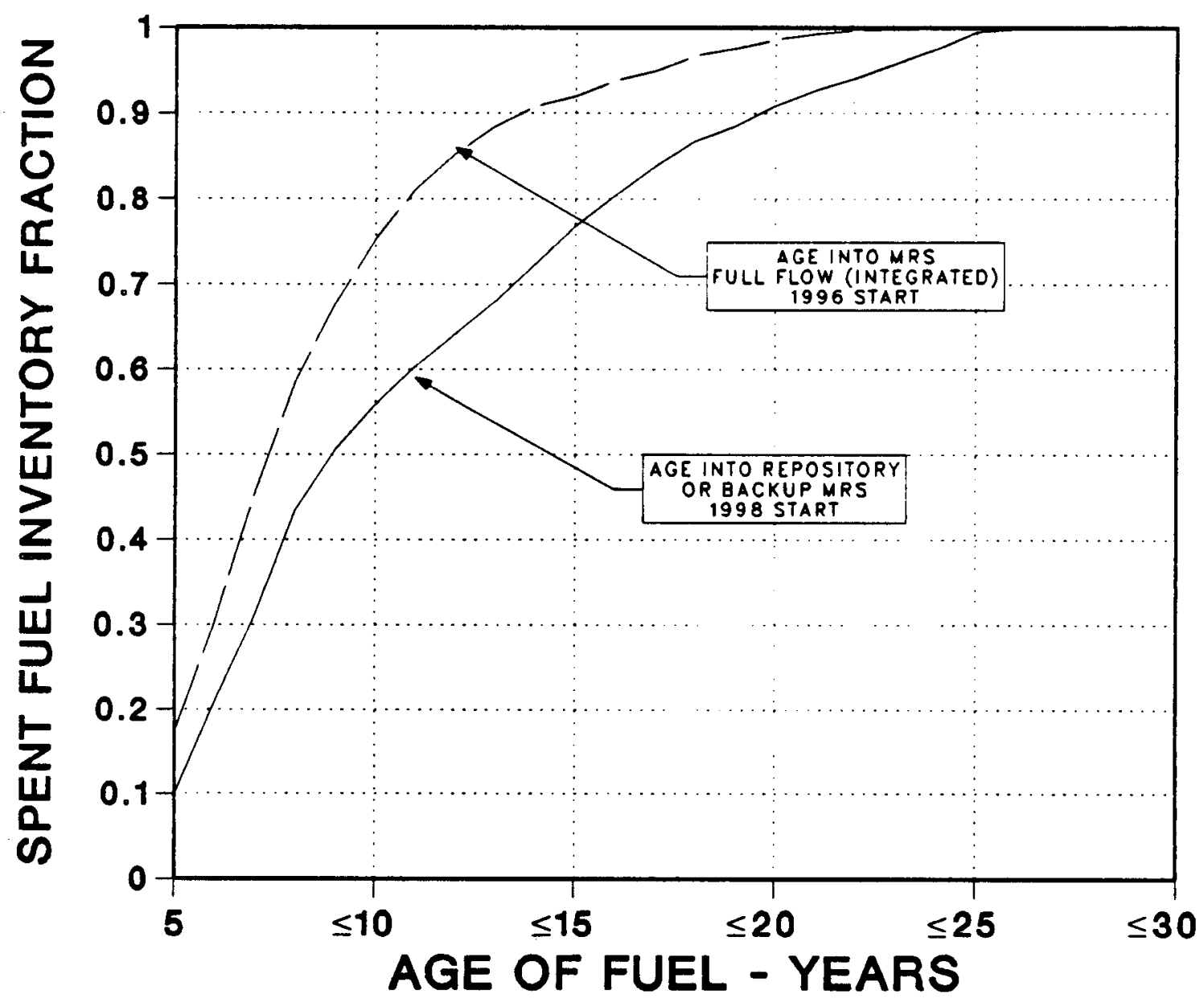

Fig. 2. Age distribution of spent fuel transfers for discharges through 2020 
distribution which formed the basis for this conclusion. Both of these figures are based on the PRDA reference acceptance schedule. In Fig. 2 it can be seen that, for the integrated MRS with a 1996 start date, approximately 75\% of the fuel leaving the reactor would be between 5 and 10 years old and $18 \%$ of the fuel would be at the minimum age limit of 5 years. An enrichment criticality limit for unburned fuel of $<3.75 \%$ U-235 was also specified from these studies.

2. For the reference PRDA inventory burnup assumptions, it appears that the reference design basis corresponding to 33,000 MWd/MTU and 10 year aging would only allow a $65 \%$ inventory handling capability for the first one-half of the total inventory. This is the fuel discharged through 2005 which would be 9 years or older at time of transfer or acceptance. The overall system inventory capability for all fuel transferred for discharges through 2020 would only be about $50 \%$. The capability, however, would be increased if the acceptance rate were slowed due to repository delays or if the acceptance spent fuel age were increased above the current 5-year requirement. It is also possible to develop more than one generation of storage and transport casks with each generation designed to handle an inventory time span. The first generation could then be designed to the current design basis. The time phased handling capability with the current reference design basis is illustrated in Fig. 3 for reference burnup assumptions .

3. Should extended burnup occur, as in certain EIA projections, the current reference design basis would be too low to handle the estimated heat load and shielding source terms and the projected handling capability would be further reduced. With an assumed $43 \%$ increase over the current 1985 burnup rates, the reference design basis would be limited to only a $35 \%$ 


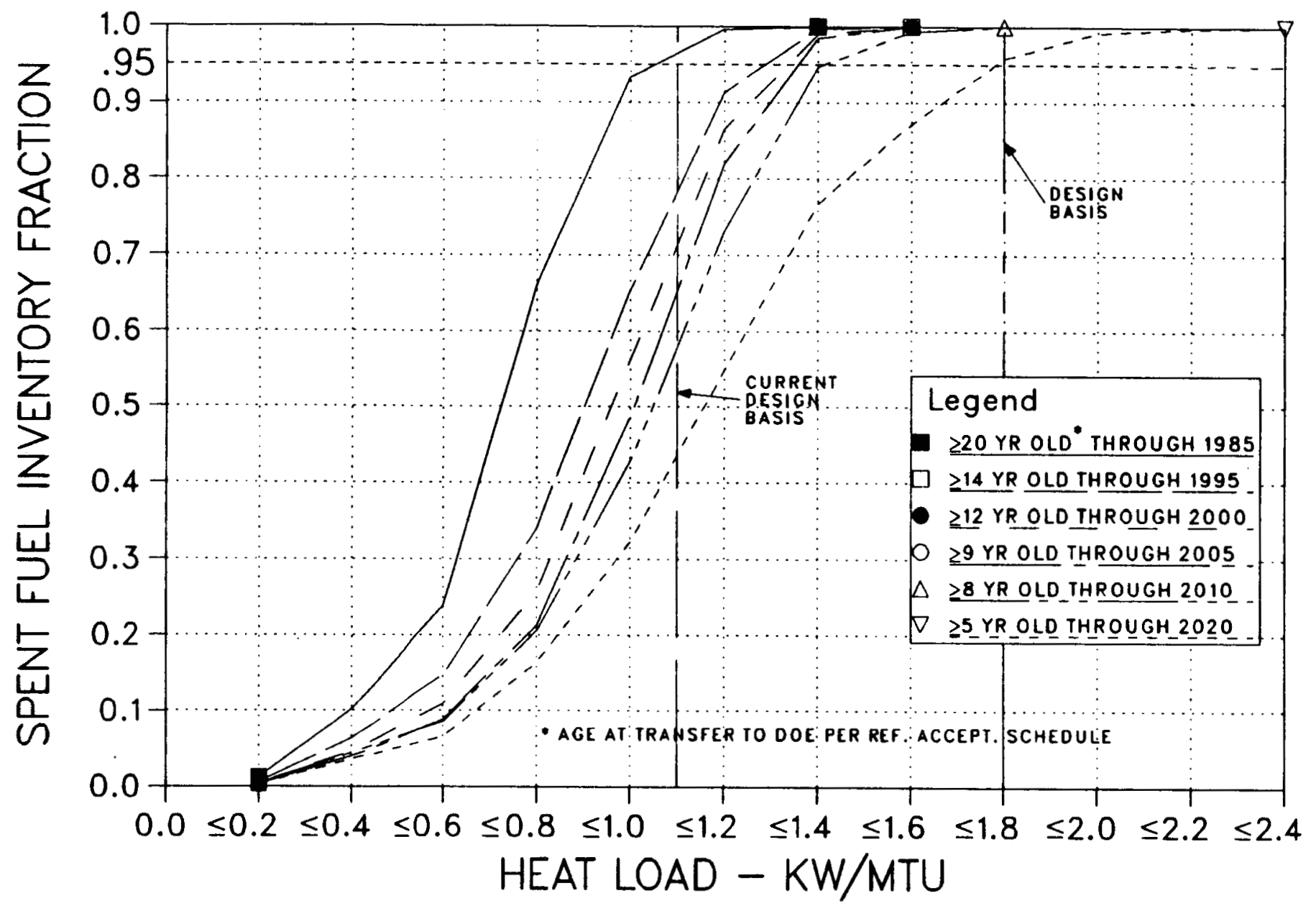

Fig. 3. Heat load distribution for reference fuel burnup 
handling capability for discharges through 2005 and to an overall inventory capability of only 20 to $25 \%$ for all discharges through 2020 as shown in Fig. 4.

4. Another useful finding from these studies shows that the gamma source strength and heat loads for differing fuel exposures and aging are nearly a constant for a given ratio of burnupto-age. For example, $30 \mathrm{MWd} / \mathrm{kg}$ burnup at 5 years aging yields essentially the same heat load and gamma source as 24 MWd/MTU 4-year or $42 \mathrm{MWd} / \mathrm{MTU}$ 7-year combinations, i.e., the burnup/age ratio is 6 in each case. Although the neutron source strength does not follow this simple rule of thumb, this relationship suggest that there is a better acceptance strategy than the "oldest fuel first"; for example, combinations of low burnup/ low age and high burnup/high age could be transferred simultaneously to more nearly levelize the heat load distribution over time into the mointored retrievable storage (MRS) or repository, if that was considered important in repository operations.

5. Another significant strategy option, which takes advantage of the fuel management capabilities inherent in the integrated MRS is to consider loading combinations of consolidated and unconsolidated assemblies in the same waste package as a method for standardizing the waste package size and heat load per package over the time horizon of repository operations. The configuration and capacity of the proposed universal canister, which would allow multiple actual or equivalent (consolidated) assembly loading from $\leq 3$ to 8 per package, was shown to allow nearly constant, yet media specific, package heat loads at or near the current waste package reference values over the total time-phase of repository operations. Figure 5 shows the different possible package configurations which could be assembled at the integrated MRS. 
C

4)

C

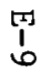

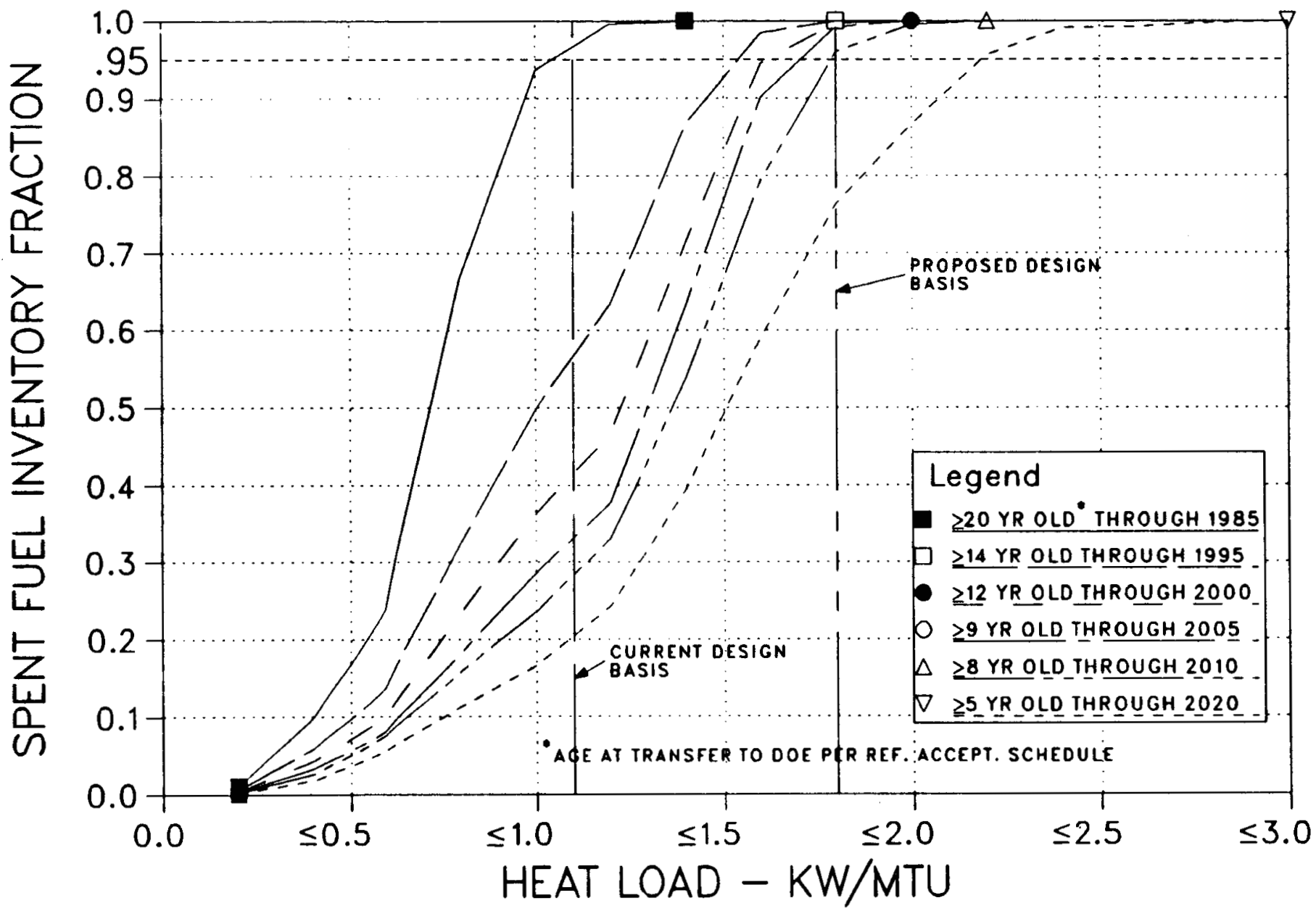

Fig. 4. Heat load distribution for extended fuel burnup 


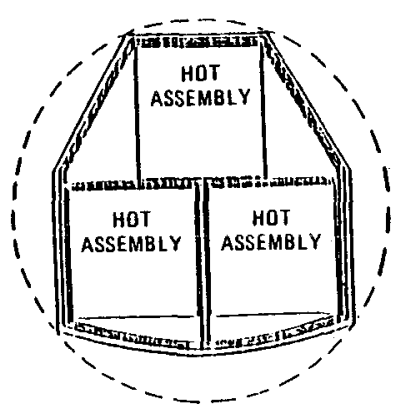

CONFIGA

TUFF/GRANITE/BASALT 3 INTACT ASSEMBLIES

\section{CONFIG C}

BASALT/TUFF/GRANITE

ONE INTACT ASSEMBLY

PLUS 4 CONSOLIDATED RODS

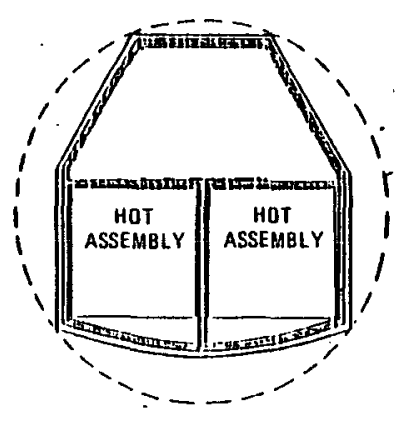

CONFIG A

BASALT
2 INTACT HOT ASSEMBLIES

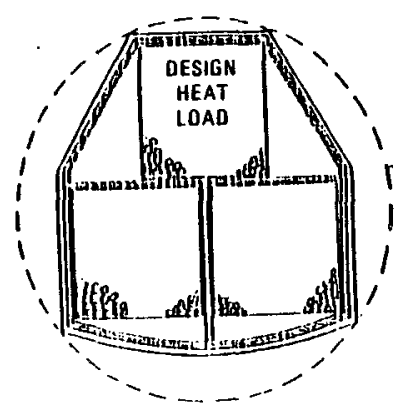

CONFIG D

SALT/BASALT/TUFF/GRANITE 6 CONSOLIDATED ROOS

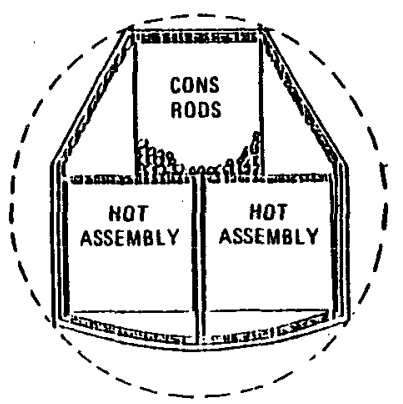

CONFIG B

BASALT/TUFF/GRANITE TWO INTACT ASSEMBLIES PLUS 2 CONSOLIDATED RODS

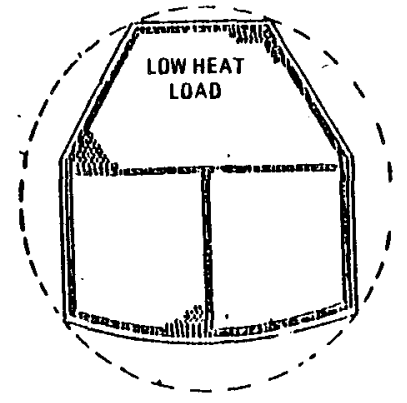

CONFIGE

SALT/TUFF/GRANITE

8 CONSOLIDATED RODS

Fig. 5. Universal canister waste package configurations for multi-media repository application 
Such a strategy, which would simplify the transport, storage, and disposal of high burnup/low aged fuel discharged after about 2010 could alleviate the problems that could result from these fuels in the later years of operation of an integrated MRS and repository.

6. The high heat loads and source strengths of spent fuel discharged after 2010 will severely reduce the payload of a system designed to store and ship final disposal packages. In the later years of the integrated MRS operations, fuel with high burnup and only 7 to 10 years of cooldown would have to be shipped in burial packages from the MRS to the repository following a minimal cooling period at the MRS. Such fuels could have more than twice the heat load and shielding source strength used for the current reference design basis. This would result in very large unit costs for shipment from the integrated MRS to the repositories. An increased burnup assumption would further compound this problem, particularly from the standpoint of neutron source strength, which could increase by a factor of three or more with extended burnup as shown in Fig. 6. Additional aging of fuel in the MRS would not significantly reduce the neutron source strengths.

\section{UNIVERSAL CANISTER SYSTẸM}

The GA system proposed for the packaging and handling of spent fuel is centered around a universal canister which contains the spent fuel during transport, storage, and intermediate handling operations. The ideal universal canister would operate effectively throughout the waste cycle, from spent fuel loading at the reactor pools, through transportation and storage missions, to final disposal at a repository. The increased system flexibility provided by an efficient canister would reduce the sensitivity to changes made in the overall waste handling 


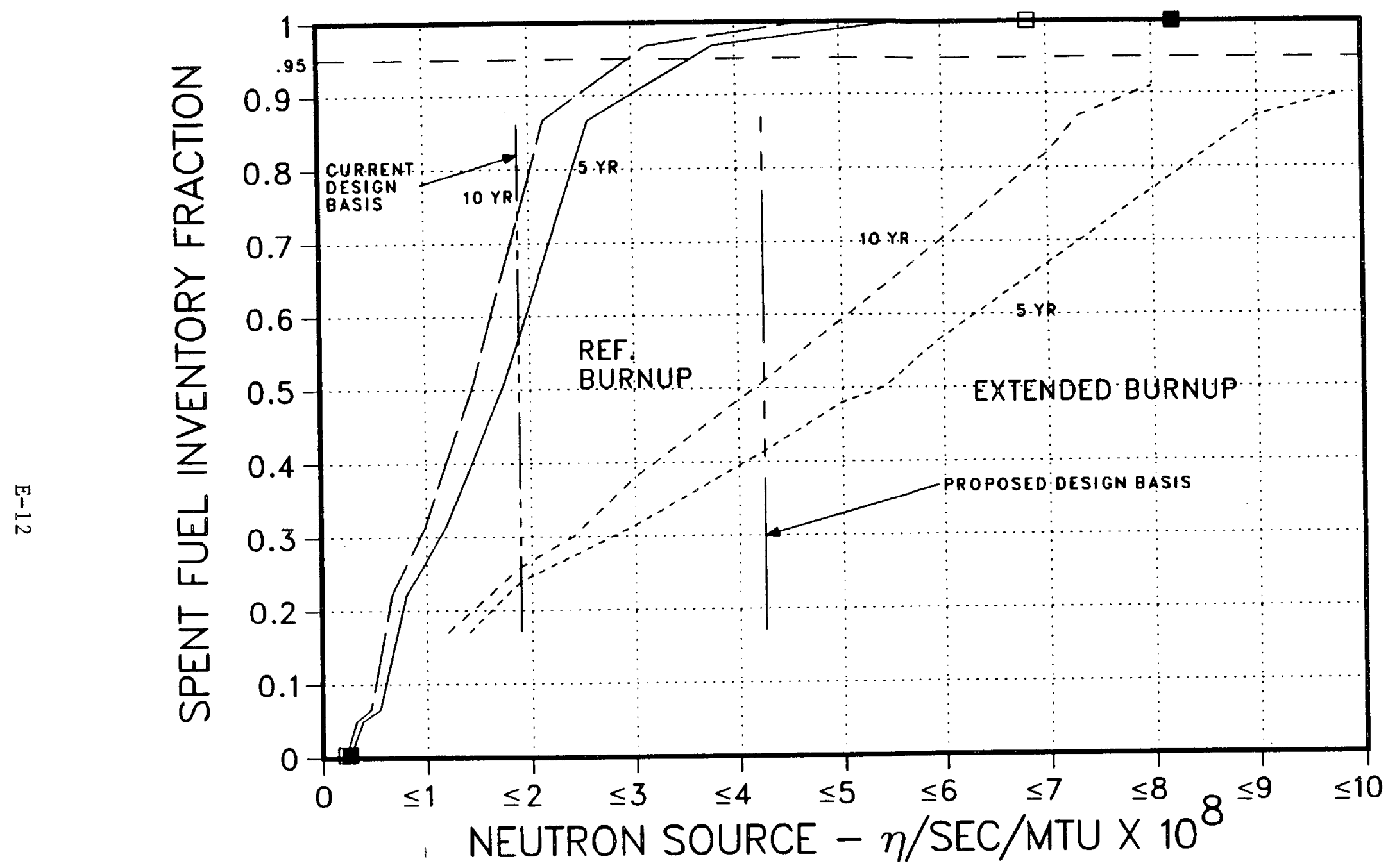

Fig. 6. Neurton source for fuel discharged in 2010 
scheme and would minimize the need for defining interfaces on systems which will be developed much later in the CRWM program.

Several canister sizes and configurations were investigated during the course of the PRDA study. These included large rail canister designs and a series of smaller designs capable of being transported by truck or rail cask. Canisters designed for transport by legal weight truck (LWT) were examined in both circular and rectangular cross-section configurations. The circular configuration was found to have limited capacity in the LWT mode for the age and burnup of the spent fuel inventory specified, and its packing arrangement in a rail cask severely limited its capacity. The rectangular cross section LWT canister was similarly limited in the truck cask because of spent fuel age and burnup shielding requirements, but it packed more efficiently in a rail cask than did the circular canister.

In parallel with the examination of truck canister configurations, a study was conducted to determine the largest capacity rail canister which can be transported by rail cask at a loaded weight limit of 100 tons. The most efficient rafl canister design identified has a circular cross section, carries 19 pressurized water reactor (PWR) or 44 bolling water reactor (BWR) intact spent fuel assemblies (SFAs), and fits within a 100-ton rail cask having a minimum cavity diameter of $57.0 \mathrm{in.}$ This design was referred to as the "alternate" canister design during the PRDA study.

After an investigation was done which confirmed the viability of truck transport at a weight exceeding the LWT limit, a canister design was found which works efficiently in both truck and rail transport modes. This design, shown in Fig. 7 and identified as the "principal" canister design, has a modified circular sector cross section which fits efficiently within a 40-ton truck cask having a minimum cavity diameter of 25.0 in., or within the 100-ton rail cask with a minimum cavity diameter of $57.0 \mathrm{in.}$ The principal canister design can operate in the truck 

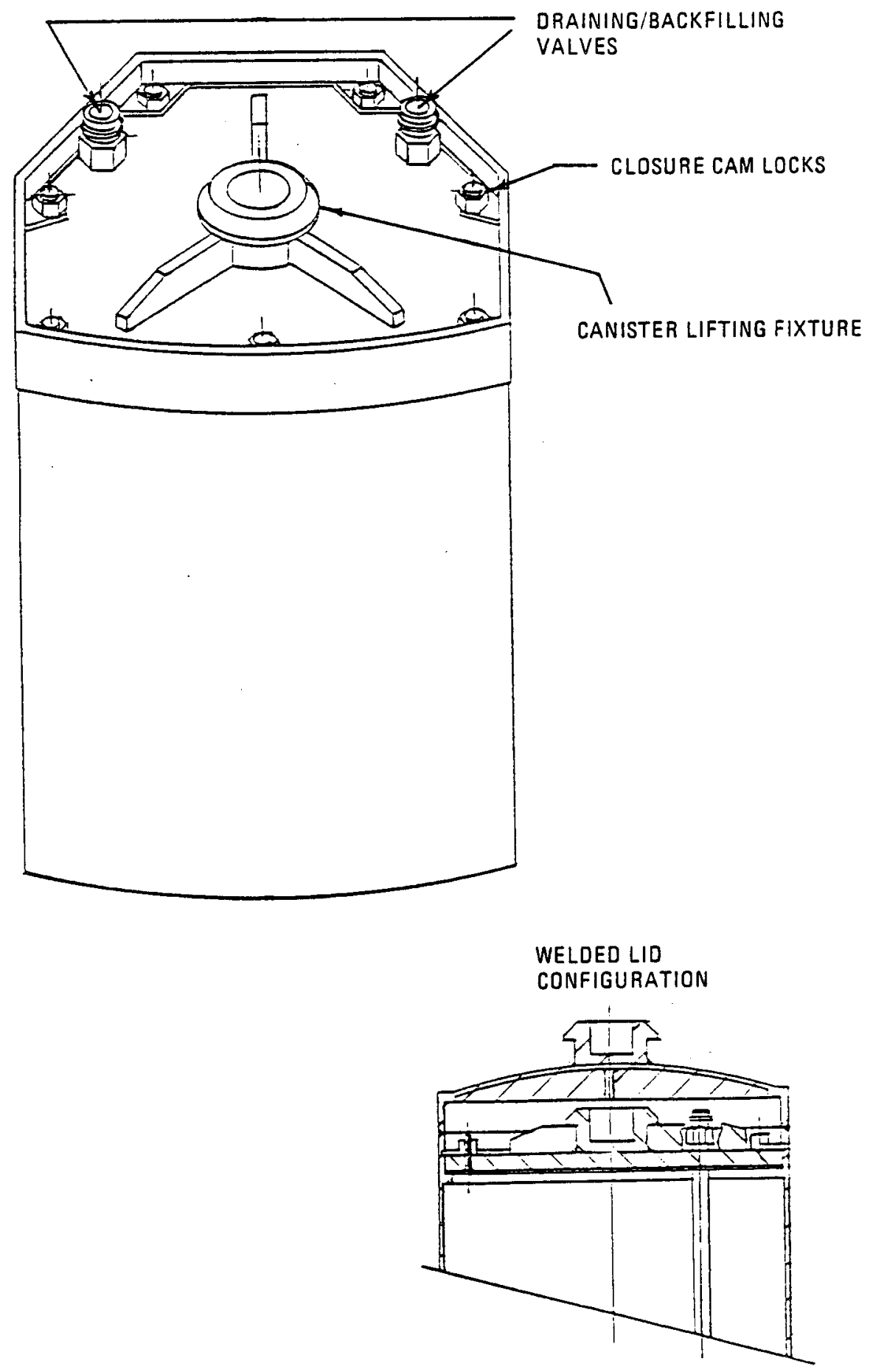

Fig. 7. Principal canister design 
transportation mode (singly), the rail transportation mode (six per rail cask), or the storage mode (six per storage cask or storage module position). The arrangement of the six canisters is shown in Fig. 8. The capacity of this canister is 3 PWR or 6 BWR intact SFAs. When loaded with consolidated fuel, this canister holds the equivalent of 6 PWR or 12 BWR SFAs for spent fuel rods consolidated at a reactor, or the equivalent of 8 PWR or 16 BWR SFAs for spent fuel rods consolidated at the packaging facility in preparation for repository disposal. As shown in Fig. 5, the canister can be reconfigured during the fuel consolidation process into a unique repository-specific package. That is, the canister would contain 4, 6, or 8 PWR assemblies for either basalt, tuff, or sa1t.

For use in a disposal package, the GA canister must be placed in a heavier wall burial container to withstand the lithostatic pressure and the long-term corrosion requirements for salt or basalt repositories. For tuff or granite repositories, the GA canister can be emplaced directly if the canister is constructed of stainless steel.

The following sections describe how the GA unfversal canister will function in the backup MRS and integrated MRS cases.

Backup MRS Case

For direct shipment from reactors to the repositories, the GA universal canisters would be loaded at the reactor spent fuel pool and either shipped immediately offsite by truck or rall transport cask or stored onsite in storage casks. The loading operation in the reactor pool is similar to loading standard shipping casks. Canisters can be preloaded or loaded while positioned inside the shipping or storage casks. The operation uses standard closure and dewatering systems. The canisters are designed to accommodate either intact SFAs or spent fuel rods from consolidation operations at the reactors. If stored onsite, the canisters would be transferred to transport casks just prior to off- 


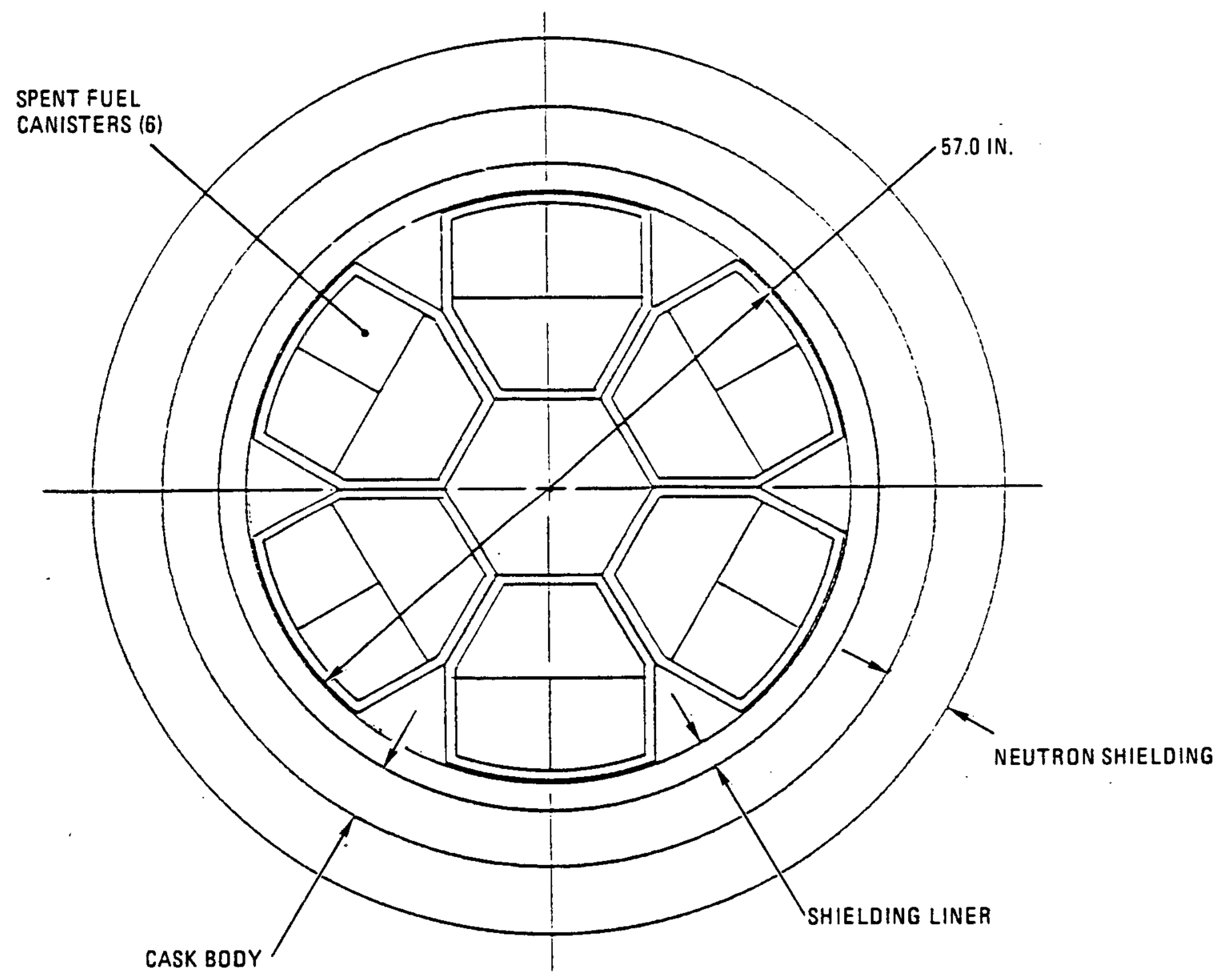

Fig. 8. Arrangement of six principal design canisters in a rail shipping cask, a storage cask, or a storage module 
site shipments. This transfer operation is unnecessary if the onsite storage casks are also qualified for offsite transportation duties. Upon arrival at a repository, the canisters can be removed from the transport casks and either sent to temporary storage or opened immediately for processing if rod consolidation is required; otherwise, they can be sealed for burial. The mechanically sealed canister lids are adequate for temporary storage outside a storage cask; however, the canisters can be sealed by welding a top cover over the mechanically sealed lid if medium- to long-term storage or disposal is required at this step.

Following rod consolidation at the repository, the spent fuel rods can be reloaded into the canisters and sealed for burial, or they can be loaded into separate disposal packages, the empty canisters being returned to the reactors for reuse. The spent fuel assembly hardware (skeletons) can also be loaded into a canister or a separate hardware disposal package. If disposal of intact SFAs is desired, the canister lids can be seal welded when they arrive at the repository, and it would not be necessary to reopen the canisters.

If a backup MRS facility is required, the canistered spent fuel can be seal welded as previously described and placed directly into storage without opening the canisters. Consolidation and canning at the MRS can be avoided, resulting in a relatively simple facility. Six loaded canisters can be stored in each storage cask or storage module position in an MRS facility. Direct shipment of the canisters to the repositories is performed when storage at the MRS facility is no longer required.

Integrated MRS Case

The spent fuel canisters are handled exactly as described in the previous case. However in this case, all shipments are made to an integrated MRS. Use of the GA canisters allows a great deal of flexibility in the operation of the MRS. When the canisters are received from the 
reactors, they can (1) be placed in surge storage awaiting the start of processing, (2) be placed in storage prior to processing and shipment to the repositories, or (3) be sent for processing and then storage prior to shipment to the repositories.

If surge storage is required prior to processing at this facility, the canistered fuel can be transferred directly upon being unloaded from the transport casks. The mechanically sealed canister lids provide double containment for short-term storage and no direct handling of the SFAs is required for this operation.

If longer-term storage is required prior to processing, the canisters can be seal welded tight before being placed into storage. The canisters can be stored six at a time in each storage cask or storage module position. Once in this configuration the spent fuel can be stored almost indefinitely pending scheduling of processing for disposal at a time convenient for the MRS or repository facilities. Following the processing operations, the spent fuel can be reloaded into the canisters and sealed for burial or additional storage, or it can be loaded into separate disposal packages and the empty canisters can be returned to the reactors for reuse. Except during the actual rod consolidation operations, handling of bare spent fuel is avolded while the fuel is being transported, stored, or transferred between these operations. The use of the sealed canisters ensures a relatively clean system outside of the actual spent fuel processing activity.

If consolidation is accomplished prior to storage at the MRS facility, the canisters would be sent to the processing area after they are unloaded from the transport casks or from surge storage. Following consolidation, spent fuel rods are reloaded into the canisters and seal welded for storage at the MRS facility and then shipped to the repositories for final disposal. Six canisters containing consolidated fuel rods can be stored in each storage cask or storage module position and six canisters can be shipped in each rail transport cask. 
The principal benefits offered by the universal canister to this case are flexibility of operations and cleanliness of systems. The flextbility allowed by the use of the canisters means that the sequence and timing of the operations at the MRS facility can be scheduled for optimum use of the facility's resources. The sealed canisters also ensure that all operations outside of the actual spent fuel consolidation area remain relatively free from contamination. This also simplifies decommissioning at a later date.

\section{Alternate Canister Design}

An alternate canister design was identified during the course of this study in addition to the principal design described above. The alternate design is a larger canister which can operate at maximum efficlency in rail transport and in spent fuel storage modes. The alternate canister design has a slight advantage over the principal canister design in those two modes ( 19 PWR/44 BWR intact SFA capacity for the principal design), but it cannot operate in a truck transport mode or be placed in a disposal package.

The alternate canister design would be very useful in a waste system dominated by rail transportation links and the need for storage capacity between the reactors and the repositories. The smaller principal canister design came to the forefront during this study because it can operate in all the modes required and because it provides greater flexibility to the entire waste system.

\section{SYSTEM ECONOMICS}

The economics of the universal canister in the CRWM system were determined for a number of scenarios. The reference CRWM system scenario, which was analyzed by Weston Consultants, provided the basis for comparison. Two sets of cases were run, and each set evaluated three repository pairs: salt/granite, tuff/granite, and basalt/granite. The 
first set evaluated the universal canister in the reference CRWM system and the second evaluated the universal canister in a system with an integrated MRS. Both assumed on-time repositories.

The WADCOM computer program was used to analyze a number of cycles required for each case. The outputs of the WADCOM cycles were combined in spreadsheets to produce the cost projections. The cost input for these cases was the same as the reference case except where these costs were specifically impacted by the universal canister and the metal storage and transport casks which were developed to operate with the canister. In the case of the integrated MRS, since there was no reference integrated MRS system, costs for the MRS were taken from work performed by Kaiser Engineers and Pacific Northwest Laboratories.

The results of the economic analyses are shown in Tables 1 and 2, which also show the costs for the reference CRWM system. The following conclusions can be made from the results.

For the reference CRWM system, where spent fuel goes directly from reactors to repositories, savings are possible with improvements in transportation and at-reactor storage systems. The universal canister can also be introduced into the system at no additional costs, since the cost of the canister is offset by savings in storage cask internals. The improvements in the transportation and storage systems can be incorporated without adopting the canister. A decision to adopt the canister would be based on the benefits of preparing a standard package at the reactor for future additional handling and storage resulting from changes or delays in the DOE mission plan.

The 640 to 810 million dollar savings in the CRWM system are attributed to changes in transportation system design. These design changes resulted from inventory analysis and canister design. Inventory ana1ysis provided design criteria which eliminated the need to derate the system if it is required to handle low cooldown and/or high burnup spent 
TABI.F. 1

RADIOACTIVE WASTE MANAGEMENT SYSTEMS COSTS

(Mill1on 1985 Dollars)

\begin{tabular}{|c|c|c|c|c|c|c|c|c|}
\hline & \multicolumn{8}{|c|}{ CRWM System } \\
\hline & \multicolumn{2}{|c|}{ Basalt/Granite } & \multicolumn{2}{|c|}{ Salt/Gran1te } & \multicolumn{2}{|c|}{ Tuff/Granite } & \multicolumn{2}{|c|}{ DRS } \\
\hline & Und i s counted & Discounted & Undis counted & Discounted & Und 1 s counted & Discounted & Und 1 scounted & Discounted \\
\hline PRDA reference & 18,300 & 8,769 & 13,747 & 6,546 & 14,393 & 6,696 & 713 & 512 \\
\hline GA reference & 17,491 & 8,431 & 13,108 & 6,278 & 13,613 & 6,368 & 551 & 391 \\
\hline GA alternate & 20,358 & 10,032 & 15,889 & 7,821 & 15,975 & 7,736 & 193 & 153 \\
\hline
\end{tabular}


TABLE 2

RADIOACTIVE WASTE MANAGEMENT SYSTEM COSTS

(Mi11ion 1985 Dollars Undiscounted)

\begin{tabular}{|c|c|c|c|c|c|c|}
\hline & DRS & CRWM & Transportation & Repository 1 & Repository 2 & MRS \\
\hline \multicolumn{7}{|l|}{ PRDA reference ${ }^{(a)}$} \\
\hline Tuff /granite & 713 & 14,393 & 1,856 & 7,007 & 5,531 & N/A \\
\hline Salt/granite & 713 & 13,747 & 1,491 & 6,725 & 5,531 & N/A \\
\hline Basalt/grantte & 713 & 18,300 & 1,929 & 10,840 & 5,531 & N/A \\
\hline \multicolumn{7}{|l|}{ GA reference } \\
\hline Tuff/granite & 551 & 13,613 & 1,080 & 7,004 & 5,528 & N/A \\
\hline Salt/granite & 551 & 13,109 & 857 & 6,723 & 5,528 & N/A \\
\hline Basalt/granite & 551 & 17,491 & 1,125 & 10,838 & 5,528 & $\mathrm{~N} / \mathrm{A}$ \\
\hline \multicolumn{7}{|l|}{ GA integrated MRS } \\
\hline Tuff/granite & 193 & 15,975 & 1,296 & 6,832 & 5,378 & 2,470 \\
\hline Salt/granite & 193 & 15,890 & 1,157 & 6,951 & 5,378 & 2,404 \\
\hline Basalt/granite & 193 & 20,359 & 1,309 & 11,110 & 5,378 & 2,562 \\
\hline
\end{tabular}

(a)From Ref. 6-2. 
fuel, thus maintaining operation of the system at its optimum payload. Developing a canister which would operate efficiently in either a truck or rail cask led to the selection of a canister which required shipment by overweight truck (OWT). Even with a speed penalty assumed for OWT, truck transportation costs were reduced $50 \%$. The savings in transportation are evident from Fig. 9, which compares the WADCOM reference CRWM system output on total number of transportation casks required per year for the PRDA versus the GA system. The PRDA system requires more casks over shorter periods of time whereas the GA system results in a more uniform cask usage over the total campaign. The impact of derating the PRDA casks can be seen by the large increase in casks in 2014.

The universal canister concept proposes that the canister be introduced into the system just prior to transfer of fuel beyond the reactor pool. The cost of the canister would be offset by savings in complex internal baskets required in storage and transporation casks. Six canisters and a support frame are estimated to cost no more than $\$ 50,000$ which is approximately the cost for a typical cask internal basket. The benefits of the canister are negligible if fuel is shipped directly from reactor pools to the repository although some savings has been estimated for standardizing the receiving and handling systems at the repository. Greater benefits are available to the reactor operator if extensive at-reactor cask storage is required. The canister provides a standard handling unt which provides flexibility in the reactor operator's dry storage system especially if the operator has several reactors on his grid of different types.

If a full flow integrated MRS is added to the CRWM system, the overall cost of the system increases by $\$ 2.4$ to 2.8 billion dollars due mainly to the cost of the integrated MRS which includes storage for 21,300 MTU of spent fuel received as a result of an early (1996) and accelerated startups. The impact of the universal canister on the system economics is negligible since the integrated MRS requires a canister 

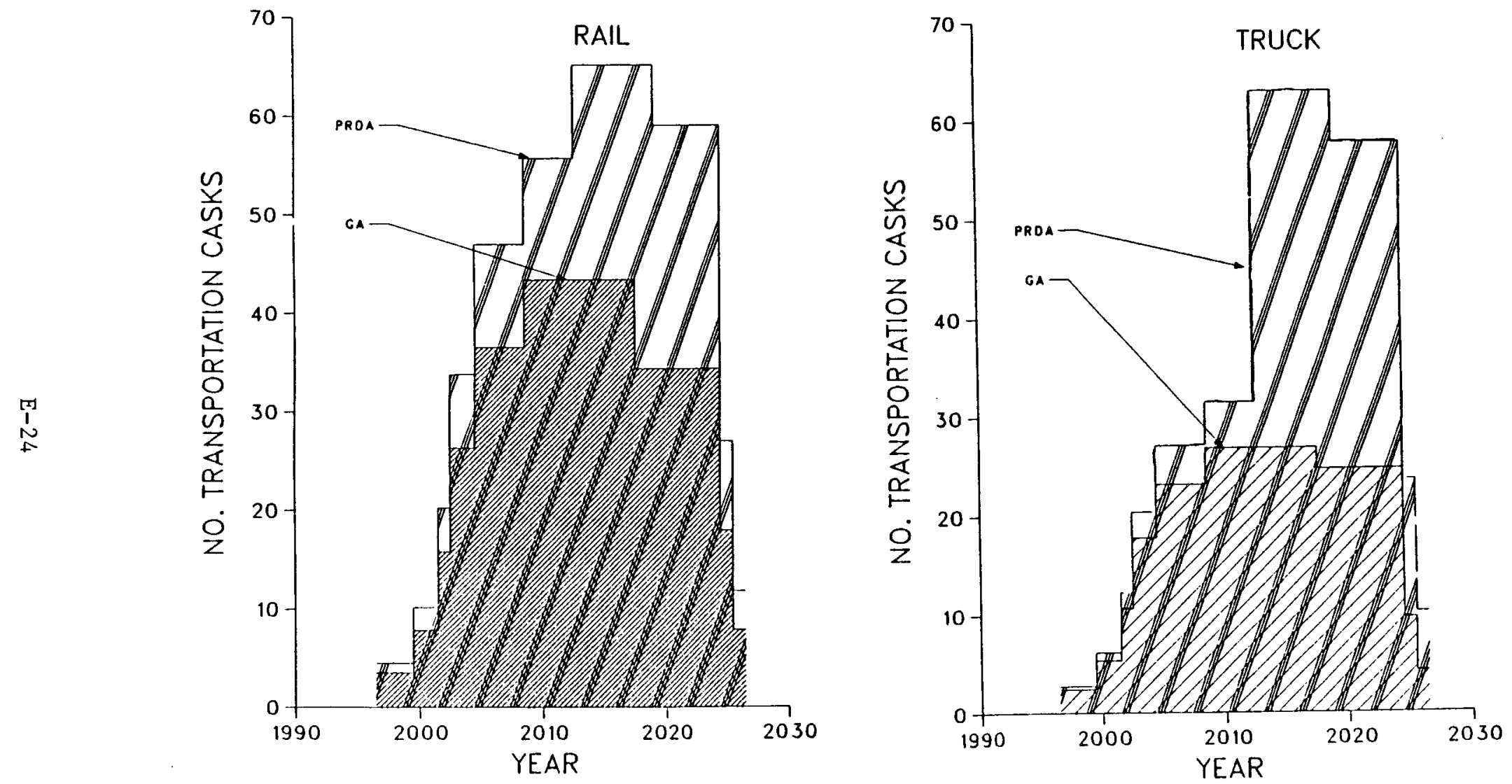

Fig. 9. Transportation cask requirements for the reference CRWM system with tuff/granite repositories 
for the consolidated fuel rods which would cost approximately the same as the universal canister, $\$ 6000$.

The increase in CRWM system cost due to adding the integrated MRS can be broken down into transportation, repository, and MRS impact areas. The results of comparing the $\mathrm{GA}$ reference system and the $\mathrm{GA}$ integrated MRS system shows an increase in transportation cost from $\$ 180$ to 300 million dollars. The increase in transportation costs between the reference and integrated MRS systems for tuff/granite repositories is evident from Fig. 10, which shows that although the maximum number of truck casks reduced from 27 to 17 , the number of rail casks increased from 42 to 105 for the integrated MRS. As shown in Fig. 11, this is due to having two separate rail cask systems: one to service reactors and one to service the MRS.

The impact on the repositories is due to moving the consolidation function to the MRS and to changes which were required on the waste package and emplacement for the different geologies. The cost impact ranged from a savings of $\$ 322$ million for tuff/granite to a cost of $\$ 122$ million for basalt/granite. The impact on the basalt was due to increasing the reference waste package diameter to accommodate the universal canister. Larger repository savings are possible if all packaging were to be done at the MRS, but the net savings would be offset by further increased transportation costs since, in this case, the overpacks would have to be transported.

The major cost impact resulting from the integrated system is the cost of the MRS, which is estimated to be $\$ 2.5$ billion. Of this, $\$ 154$ to 216 million dollars is the cost of storing 21,300 MTU of consolidated spent fuel in concrete storage casks as shown in Fig. 12 for tuff/granite repositories. $\$ 120$ million is the cost of consolidating the spent fuel, and $\$ 2$ billion is the cost of operating the facility. Because final packaging is done at the repository in the GA concept, the 

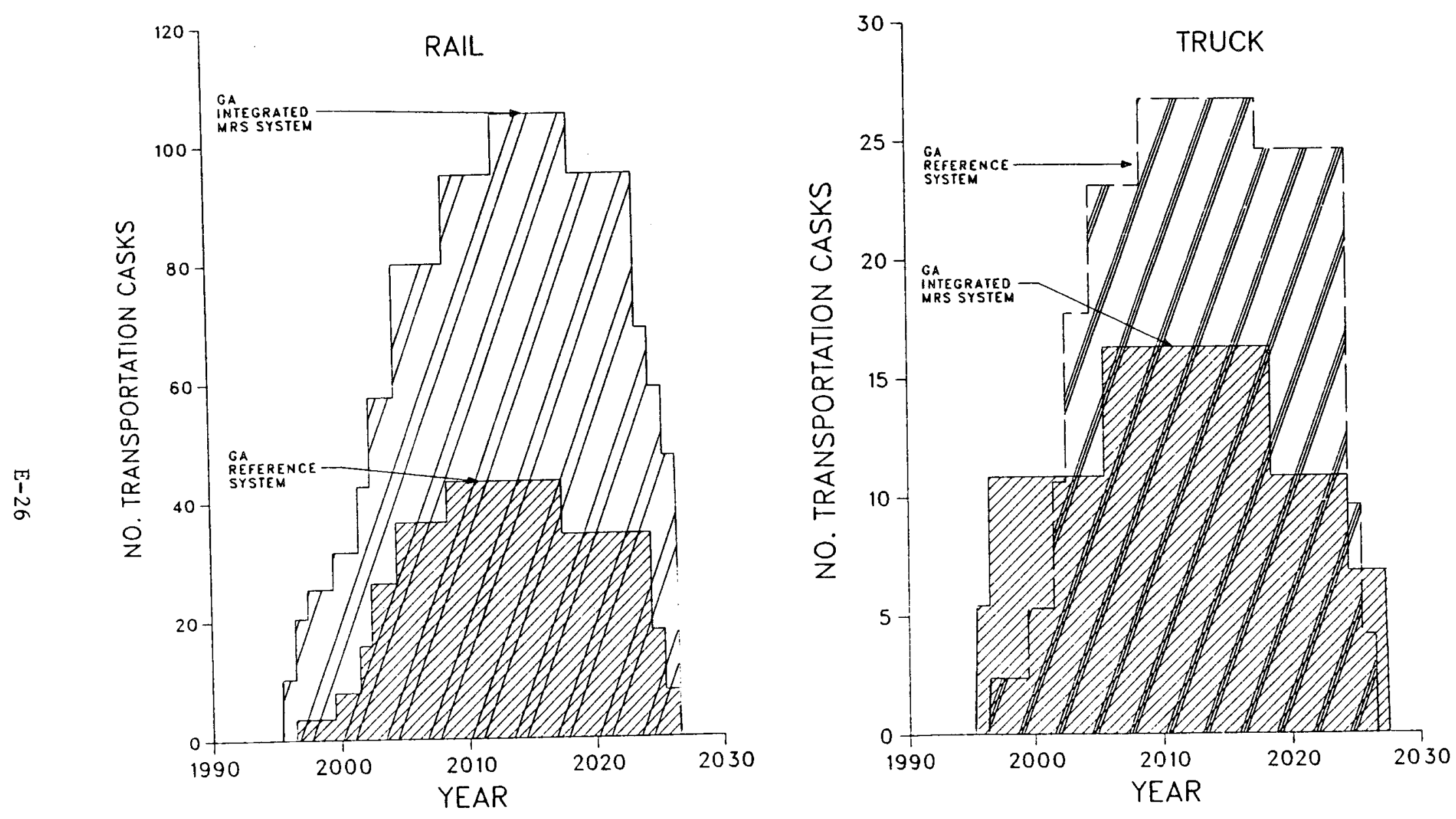

Fig. 10. Comparison of transportation cask requirements between the reference CRWM system with tuff/granite repositories and the integrated MRS system 


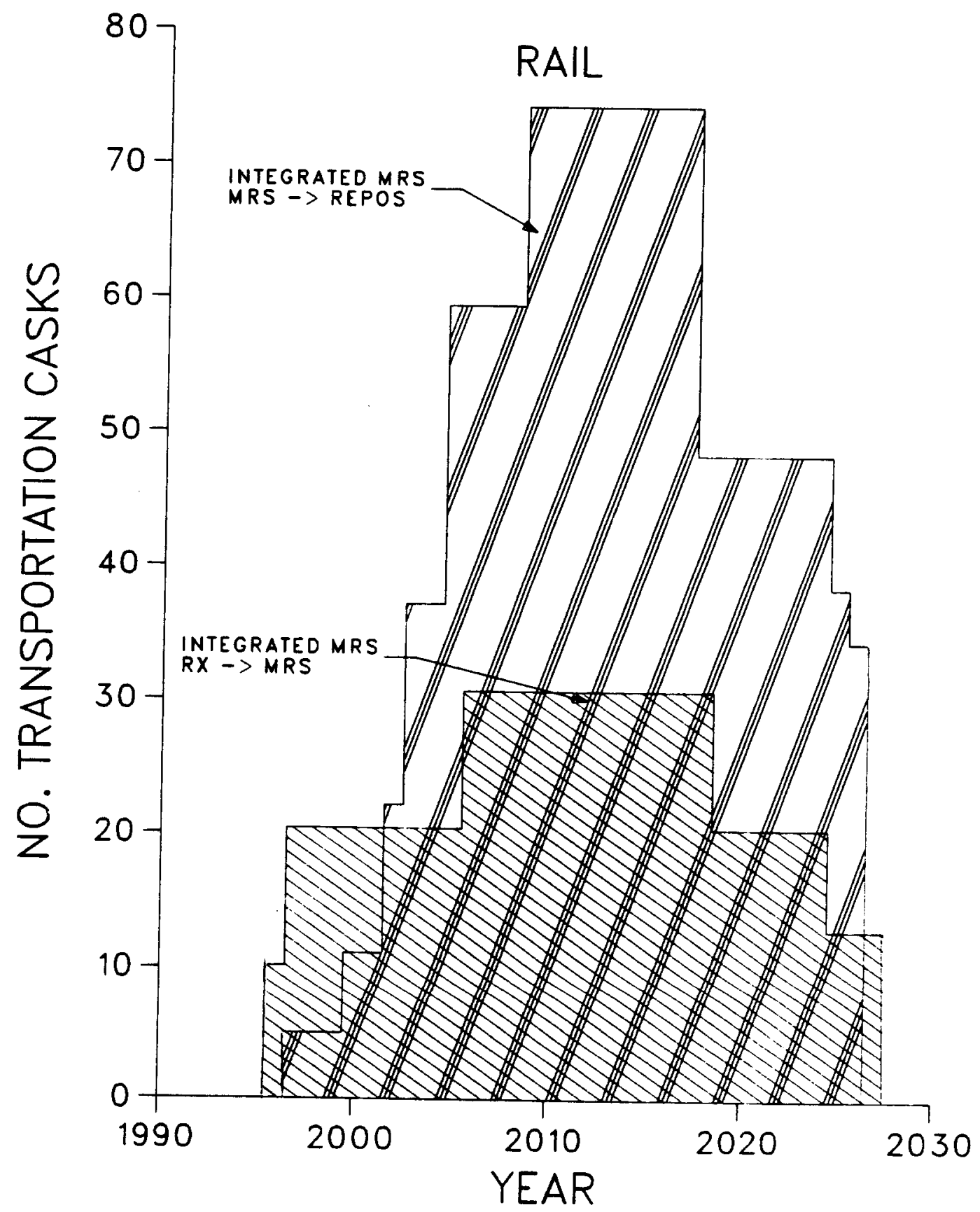

Fig. 11. Rail cask requirements for the integrated MRS system with tuff/granite repositories 


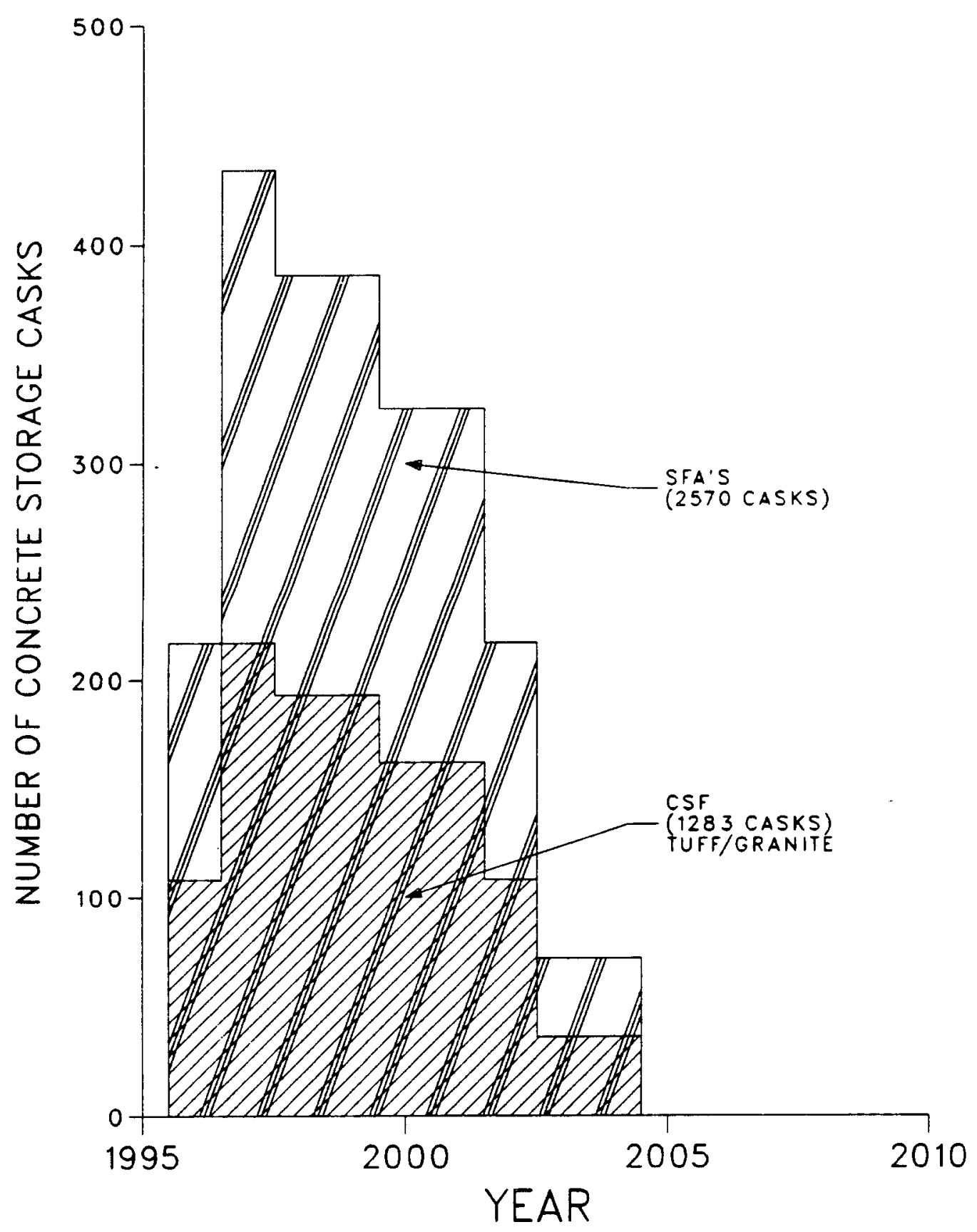

Fig. 12. Deployment schedule for irtegrated MRS concrete storage casks 
MRS operating costs were not offset by equivalent reduction in repository operating costs.

Early operation of the MRS however results in a reduction of storage requirements at-reactor, as shown in Fig. 13. This provides a savings of $\$ 360$ to $\$ 520$ million dollars, depending on which dry storage system is used, GA design or PRDA reference.

\section{SYSTEM FEASIBILITY}

Both the CRWM system and the universal canister have been evaluated to ensure their technical, licensing, economic, environmental, and socioeconomic feasibility. The universal canister itself is technically feasible, since it is relatively simple in design, uses readily available materials, can be manufactured in existing facilities, and can be readily handled with standard equipment. The universal canister concept has undergone sufficient analysis to predict its performance. Canisters have been used to contain leaking fuel or to ship and transport fuel for a number of years and therefore they do not require any new technology development.

The technical feasibility of the CRWM system with the universal canister was evaluated by examining each element of the system to determine the degree of flexibility provided by the universal canister. Preloading of canisters in the reactor pool improved the handling of the spent fuel for storage or transport. The universal canister provides a standard package and improves the utilization of the at-reactor and MRS storage casks. The greatest increase in flexibility occurs at the integrated MRS. With the spent fuel arriving in a clean canister, several options are available to the operator for storage, consolidation, and final packaging. With the repository receiving a standard clean canister, overpacking systems can be simplified and the processing lines can be identical rather than requiring different equipment for the different types of fuel. 


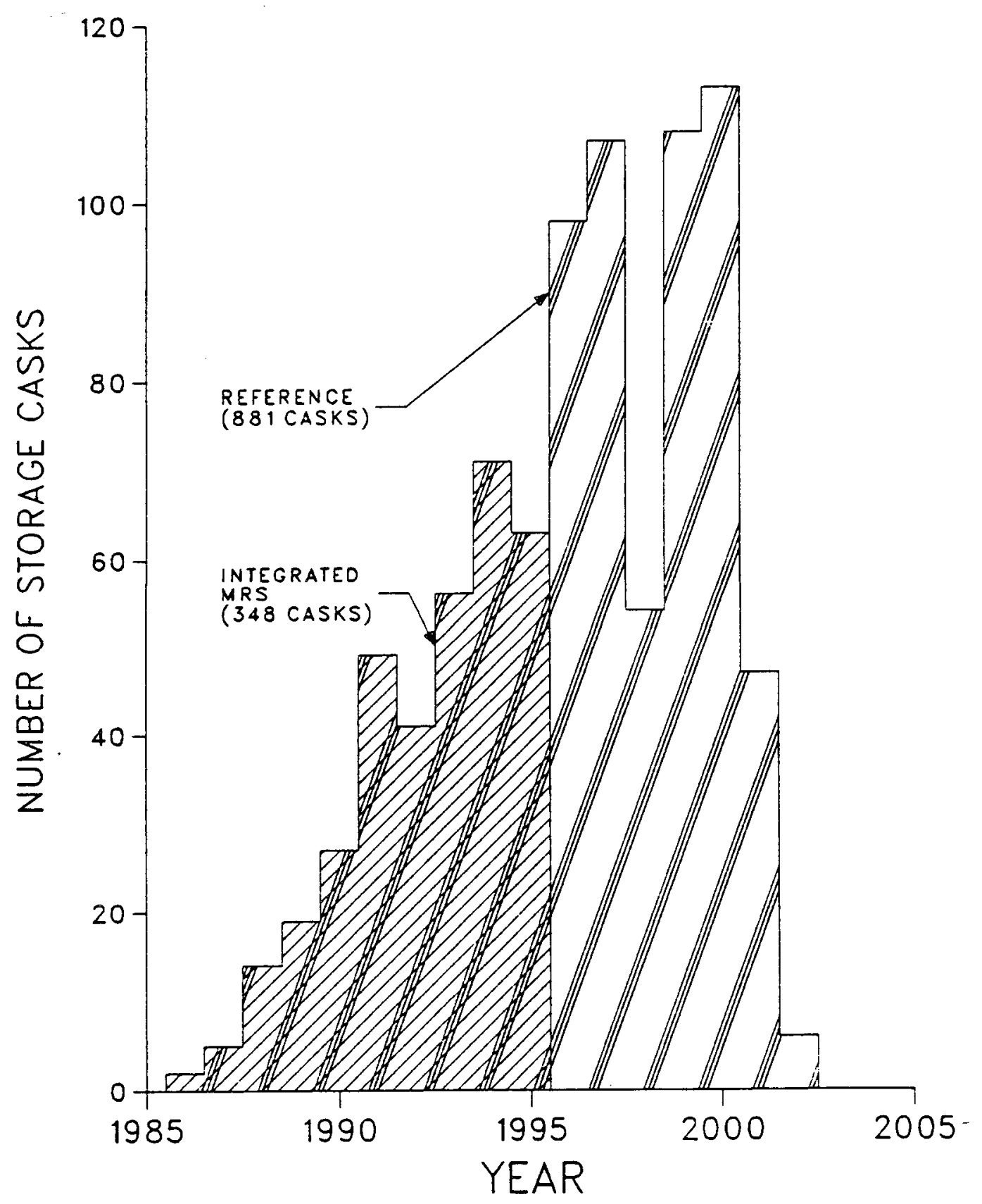

Fig. 13. Deployment schedule for at-reactor storage casks 
The universal canister also offers improved flexibility for meeting repository waste package heat load limits. This is particularly important when the age of the fuel decreases and the burnup increases. As explained in paragraph 1, canisters can be loaded with a combination of intact and consolidated fuel assemblies so that the repository receives a package with a specified heat load. The package contents would range from all consolidated to all intact spent fuel.

Safety and licensability is enhanced with the universal canister since it provides an additional barrier within the licensed storage or transport cask as well as providing containment of radioactive contamination during handling and storage. Spent fuel handling facilities remain relatively free of radioactive contamination, and the amount of secondary low level waste is substantially reduced. Contamination can be primarily limited to the consolidation area.

The addition of a canister in the CRWM system is economically feasible since the cost of the canister is minor compared to the total system cost. Without considering any savings due to the canister, the approximately $\$ 200 / \mathrm{kgU}$ system cost would be increased by $\$ 2 / \mathrm{kgU}$, which is well within the level of cost uncertainties. The benefits provided by this small incremental cost make the universal canister economically feasible. In addition, savings are expected in handling costs, operating costs, and decommissioning costs. However, these savings are difficult to estimate at this time because system designs have not been sufficiently developed.

No significant adverse environmental, ecological, or socioeconomic impact was identified with adoption of the universal canister. 
5. RECOMMENDATIONS FOR SYSTEMS ANALYSIS AND CONCEPT DEVELOPMENT

The concept of a universal canister is not only compatible with DOE's proposed integrated MRS but can potentially improve its flexibility. The integrated MRS will need to to utilize a canister for processing and storing spent fuel. Further systems analyses are recommended to better define the canister functions within the MRS so that the resulting canister design enhances rather than limits the flexibility of the CRWM system. The following sections provide specific recommendations for systems analysis and concept development.

\section{Spent Fuel Management}

More extensive spent fuel management studies could show the potential of the integrated MRS to manage the flow of spent fuel from reactors to disposal under different sets of criteria, to establish the optimum cost and operations basis, and to determine how the MRS can accommodate uncertainties in the flow of spent fuel.

By introducing the concept of an integrated MRS, DOE has provided the capability for solving several difficult problems in the back end of the nuclear fuel cycle. These include at-reactor storage needs and spent fuel age/burnup limitations in transport, storage, and disposal systems. Further fuel management studies are needed to develop an optimum acceptance schedule for spent fuel shipments from reactors, to determine the MRS storage requirements, to select optimum canister loadings, and to establish a rate of flow of processed spent fuel to the geologic repositories.

There is considerable uncertainty in the generation and flow of spent fuel from reactors. Since the bulk of the spent fuel inventory is from future reactor discharges, spent fuel management studies are needed to determine how these uncertainties would impact the integrated MRS and 
what degree of flexibility would be required to cope with the range of spent fuel characteristics that might result.

The integrated MRS provides the CRWM with the capability to improve the current waste acceptance strategy of "oldest fuel first," which results in significant changes in heat load and shielding requirements during the geologic emplacement of the spent fuel. The inventory analysis performed this year has shown that heat load and the gamma shielding source term are nearly proportional to burnup for a given decay time. Additional studies are needed to develop an acceptance strategy based on equivalencing of burnup and aging to more nearly levelize shielding source terms and heat load for spent fuel prior to disposal in the repositories.

\section{Integrated MRS Systems Studies}

Flexibility in the CRWM system will depend on the degree of flexibility of the systems within the integrated MRS facility. A study of alternate process flowsheets for the integrated MRS is recommended to examine the different functional requirements which may arise during the implementation of the CRWM system.

An understanding of these functional requirements during the system definition phase of the integrated MRS development will determine the degree of flexibility which can be made avallable. These functional requirements generally include cask handling as well as spent fuel handling, processing, and storage. More speclfically, they must address what different cask types must be handled, what different fuel forms will be recelved at, and later shipped from, the facility, what options are avallable for processing the spent fuel, and what different fuel forms require storage. 
The systems analysis can determine the impact of setting different functional requirements and suggest approaches to maximize the flexibility of the integrated MRS to respond to yet-to-be-defined or changing requirements. It would help determine the need for, and the timing of rod consolidation of, fuel requiring storage prior to disposal by considering the impact of storing intact versus consolidated fuel in different canister designs. It would examine the options for selecting a consolidation canister if the disposal canister or the repository is not defined when fuel is recelved in the facility, and it would determine the impact on the facility of selecting specific canister designs. Timing and location of final packaging for disposal would be evaluated to determine the impact on the integrated MRS, transportation, and the repository.

Concept Development

A better definition of canister requirements resulting from the systems studies outlined above will provide a basis for further canister definition and development. The canister proposed in this report was designed to meet certain requirements and should be reexamined in light of any new requirements resulting from additional studies or changing parameters.

It may also be possible to develop two sets of canister/cask systems, with the first set addressing the early inventory and its older fuel with lower burnup. A second generation of casks would then be introduced around 2015 for the younger/high burnup fuel.

If the systems studies determine that a universal canister is not appropriate for a CRWM system with an integrated MRS, a canister will still be needed for processing and storage within the MRS it flexibility of the system is to be maintained. 


\section{REFERENCES}

1. "Mission Plan for the Civilian Radioactive Waste Management Program," DOE/RW-0005 Draft, April 1984.

2. McKee, R. W., Pacific Northwest Laboratories, private communication to R. P. Morissette, GA, January 28, 1985. 


\section{INTRODUCTION}

The reference Commercial Radioactive Waste Management System (CRWM) involves shipment of spent fuel directly from reactors to two repositories using truck and rail shipping casks. The Mission Plan for the Civilian Radioactive Waste Management Program (Ref. 1-1) includes a number of contingency systems which would become part of the CRWM system as required to implement the Nuclear Waste Policy Act of 1982. These include at-reactor storage, emergency interim storage, and monitored retrievable storage. These contingency systems made it apparent that the management of nuclear waste would involve major resource investments in facilities, equipment, construction, and operation and would include an as-yet-undetermined number of discrete packaging, handling, and shipping operations. Because of this, a Program Research and Development Announcement (PRDA) was Initiated by the Department of Energy (DOE) to solicit from industry new and novel ideas for improvement of the CRWM system.

The solution proposed by GA Technologies Inc. (GA) consists of a multi-element system for storing and transporting spent fuel. Four basic elements make up the multi-element system: universal canisters, storage casks, concrete storage modules, and transportation casks.

The primary element of the system is a universal canister that will contain intact or consolidated pressurized water reactor (PWR) or boiling water reactor (BWR) spent fuel assemblies while providing standardized handling from reactors to repositories. It consists of a thinwalled steel container with either a bolted or a welded closure that is capable of wet or dry loading/unloading. It will form an integral part of the storage and transportation units that contribute to the remainder of the proposed system. This use of a standardized canister design 
provides significant economic advantages because it establishes a common interface with the handling, storage, and transporation elements of the proposed system.

The storage cask element of the system is thick walled with a bolted or welded enclosure for storing a universal canister of spent fuel. The cask is capable of wet or dry loading/unloading, and can be used for near-term small-capacity cask storage facllities as well as for transfer of spent fuel to onsite storage module facilities.

The storage module element of the system is a passively cooled storage facility that uses concrete storage modules or casks for longterm large-capacity storage. The modules accept universal canisters of spent fuel, provide continuous monitoring capability, and interface with storage and transport casks.

The fourth element of the system, the transport cask, is thick walled and is used for public highway/rail transportation. It accepts a universal canister of spent fuel and is capable of wet or dry loading/ unloading .

GA was contracted by DOE to study a universal canister which could be loaded in the fuel storage pools at reactor sites and would subsequently interface with at-reactor dry storage, transportation, interim storage, monitored retrievable storage, and repository receiving and handling. The objective of the study was to develop an understanding of the spent fuel inventory and use this as a basis for developing and evaluating canister concepts. The goal of the study was to select a canister concept for handling, shipping, and storing spent fuel so as to minimize packaging and handling and maximize flexibility and standardization of interfaces and equipment.

The approach proposed by GA to meet this objective involved a comprehensive analysis of the physical inventory of spent fuel requiring 
packaging, handling, storage, and transporation. This detail knowledge of the time-dependent inventory characteristics provided the basis for a set of design criteria used to develop a canister within the multielement system. The analysis, using data provided by Pacific Northwest Laboratories (PNL) and Oak Ridge National Laboratory (ORNL), converted the burnup and decay age distribution into time-phased inventory distribution for heat load, gamma, and neutron shielding sources.

The development of the universal canister resulted from engineering design and analysis of a canister/cask combination to meet the design criteria while maximizing the payload within the constraints of the system.

The universal canister would be loaded in the reactor pool, providing a standard package for all subsequent handling, shipping, and storage operation. If consolidation was to be performed at an intermediate storage facility, the consolidated fuel would be returned to the unfiversal canister which would then be loaded into the disposal package.

DOE provided all PRDA contractors with a set of assumptions to be used in the study. These included a definition of the reference and alternate waste management systems, waste acceptance schedules for both systems, and economic assumptions. This document, Ref. 1-2, provided the basis for GA's study.

GA's study was divided into two tasks, systems analysis and conceptual design. The systems analysis task included an analysis of the spent fuel inventory and of the CRWM missions. The systems analysis task provided the basis for developing the universal canister. The conceptual design task identified requirements and developed designs and cost estimates of the proposed canister system. The proposed system was evaluated using economic analysis and feasibility studies.

This report presents the results of GA's PRDA program studies. 


\section{REFERENCES}

1-1. Mission Plan for the Civilian Radioactive Waste Management Program," DOE-RW-0005 Draft, Apri1 1984.

1-2. "Assumptions for Analysis Responding to the Program Research and Development Announcement (PRDA) for Nuclear Waste Packaging and Handling Design 1 Initiative," Roy F. Weston, Inc., and U.S. DOE, March 6, 1985. 


\section{THE TIME-PHASED CHARACTERISTICS OF THE NUCLEAR WASTE INVENTORY}

A detailed analysis of the time-phased LWR discharge fuel inventory is an underlying concept of the GA's PRDA systems studies. This timephased inventory analysis has been carried out to determine a knowledge of the statistical distribution of those inventory characteristics which impact the transport and storage system design, particularly the payload of a universal canister which can be used in this system. These results may also be used to assess the relative inventory handing capabilities of other systems and/or facilities such as those based on the DOE reference design criteria (33,000 MWd/MTU, 10-year cooling) or, for example, the REA-2023 transport/store cask.

PNL has the responsibility for surveying the utilities to obtain 1ight-water reactor (LWR) discharge data related to current and future spent fuel storage requirements. The current PNL data base was provided to GA in late January 1985, and these results, along with additional calculational results, form the basis for these inventory analysis results. The detailed results of these inventory analyses are included in Appendix A to this report.

GA's process involved expanding the existing data base to include:

1. The time-phased thermal and shielding source term data for the entire inventory over the duration of the various missions required for the selection of the canister design and missionspecific storage and transportation element designs.

2. An assessment of the initial fissile distribution data required for a comprehensive understanding of the actual criticality limitations imposed by the fuel inventory that may 
Iimit the achievable canister loading for intact fuel assemblies in certain mission applications.

The time-phased inventory analysis has been aimed at determining the statistical distribution of those inventory-imposed constraints that impact the universal canister payload capability in the various missions considered. From the statistical analysis of the potential canister limiting constraints imposed by the inventory character, a common figure of merit was adopted whereby an acceptable canister size or configuration was identified to meet $>95 \%$ of all the inventory characteristics that impact the optimum universal canister size.

The PRDA assumptions specify that $70 \%$ (by weight) of at-reactor (AR) shipments to either the monitored retrievable storage (MRS) or the mined geological repository (MGR) are rail and $30 \%$ (by weight) are truck shipments. All shipments from the MRS to the MGR are by rail. AlI rail shipment weights are limited to a 100-ton cask allowable from AR to either the MRS or the MGR and 150 tons allowable from the MRS to the MGR.

As a result, the inventory analysis focused on specifying an optimum size related to a rall transport system including storage casks, transport casks, and storage modules. The results from these analyses were used directly in later specifying an overweight truck canister size to be used in the truck shipment mode of transportation and/or storage. This specification was also adaptable for use in rail transport, i.e., six overweight truck canisters in combination make up a rail transport system.

The canister and cask studies have assumed that the universal canister would have the following characteristics:

1. It would be used for transport and storage of both PWR and BWR fuels, either as assemblies or as $2: 1$ consolidated fuel rods. 
A different basket design is utilized for the two types of fuel.

2. It would be contained in the same transport cask for both BWR and PWR fuel transfers.

3. It would have a payload capability for transporting and/or storing up to at least $95 \%$ of all fuel that requires transport or storage over the time span of the various missions involved, 1.e., AR, MRS, and MGR. This includes transport and storage either of assemblies or of the more limiting consolidated rod transport and storage (where applicable).

More specifically, the canister size selection process involved several iterative comparisons of canister payload capability and transport cask weight analysis as impacted by the various inventory characteristic distributions. A maximum canister diameter (maximum MTU capability) was investigated and determined from the composite of the following technical considerations:

- Meeting the 100-ton cask weight with assemblies for $>95 \%$ of all inventory to be transferred from the reactors in either the MRS or MGR missions.

- Meeting the criticality imposed constraints of $k_{\text {eff }}<0.05$, based on the unburned MTU fisslle enrichment distribution for $>95 \%$ of the MTU inventory.

- Meeting the inventory heat load distribution in all missions as a combination of burnup and age that would be expected to result in a clad temperature 1 imit of $\left\langle 375^{\circ} \mathrm{C}\right.$ for $>95 \%$ of all fuel to be stored or transported as assemblies or consolidated fuel. 
- Meeting the inventory gamma and neutron shielding source terms in all missions, as a combination of burnup and age, that would be expected to yield acceptable dose rates and the rail transport cask weight limit for $>95 \%$ of all fuel to be stored or transported as assemblies or consolidated fuel.

Additional details of the impact of the inventory-imposed constraints on the selection of the universal canister storage and transport system characteristics and optimization are given in Appendix $A$ and in Section 2.2. of this report.

\subsection{WASTE ACCEPTANCE SCHEDULE VERSUS BURNUP AND AGE}

\subsubsection{Impacts Due to Age}

The current waste acceptance schedules from reactors to either MRS or repository shown on Tables $2 \cdot 1-1$ and $2 \cdot 1-2$ are based on an "oldest fuel first" policy. This acceptance strategy results in a continuously decreasing decay age of fuel to be accepted at either the MRS or repository over the time frame of the operations of either facllity. For example, the decay age of fuel to be transported and stored at an MRS or repository that starts operating in 1998 will initially be from fuel that was discharged from reactors in the $70^{\prime} \mathrm{s}$ and aged 25 or more years. Since the acceptance schedule exceeds the reactor discharge rate, the average age at acceptance continuously decreases so that by approximately 2014 the age has decreased to 10 years and by approximately 2022 to about 5 or 6 years.

The approximate age at acceptance or emplacement for the base case, a 1998 repository startup, is shown as a function of time in Fig. 2.1-1. Scenarios involving a 1996 MRS facility accelerated start would lead to even younger fuel being transported and stored. 
TABLE 2.1-1

REFERENCE CASE WASTE ACCEPTANCE SCHEDULE

\begin{tabular}{|c|c|c|c|c|c|c|c|c|c|}
\hline tear & 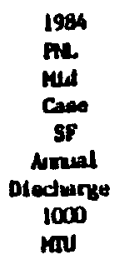 & 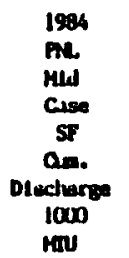 & $\begin{array}{c}1984 \\
\text { PL } \\
\text { HId } \\
\text { Cres } \\
\text { OE. } \\
5 \text { Yr. Old } \\
\text { SF } \\
\text { IOM } \\
\text { MNU }\end{array}$ & $\begin{array}{l}\text { EIne } \\
\text { Repoeltory } \\
\text { Mulaw! } \\
\text { Recelpt } \\
\text { Flrst } \\
\text { Stage } \\
1000 \\
\text { HaU }\end{array}$ & 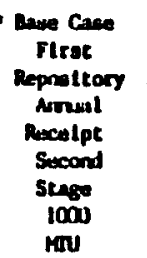 & 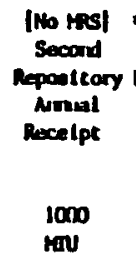 & 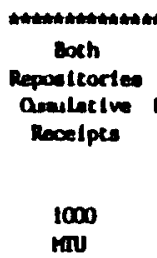 & $\begin{array}{l}\text { Spene } \\
\text { Anal y } \\
\text { anclog }\end{array}$ & $\begin{array}{l}\text { Five } \\
\text { Year } \\
\text { Utd } \\
\text { Backlog }\end{array}$ \\
\hline $\begin{array}{l}1983 \\
\text { I984 }\end{array}$ & $\stackrel{M}{M}$ & $\begin{array}{l}10.1 \\
11.3\end{array}$ & & & & & & & \\
\hline I995 & 1.5 & 12.1 & & & & & & & \\
\hline 1986 & 1.5 & [6.J & & & & & & & \\
\hline $\begin{array}{l}\text { I981 } \\
1988\end{array}$ & 1.7 & 16.2 & & & & & & & \\
\hline 1980 & 2.1 & 18.0 & 10.1 & & & & & & \\
\hline $\begin{array}{l}1999 \\
1990\end{array}$ & 2.1 & 20.2 & 11.1 & & & & & & \\
\hline 1980 & 2.2 & 22.3 & 12.7 & & & & & & \\
\hline 91 & 2.2 & 24.6 & 14.3 & & & & & & \\
\hline 1992 & 2.3 & 26.9 & 160 & & & & & & \\
\hline 93 & 2.4 & 29.1 & 18,0 & & & & & & \\
\hline 1994 & 2.6 & 3t.9 & 20.2 & & & & & & \\
\hline 1995 & 2.5 & 36.4 & 2.3 & & & & & & \\
\hline 1996 & 26 & 310 & 24.6 & & & & & & \\
\hline $\begin{array}{l}1997 \\
1998\end{array}$ & $\begin{array}{l}2.7 \\
2.6\end{array}$ & $\begin{array}{l}39.8 \\
42.4\end{array}$ & $\begin{array}{l}26.9 \\
29.3\end{array}$ & 0.4 & & & 0.4 & 420 & 28.9 \\
\hline 1999 & 2.7 & $\begin{array}{l}42.4 \\
43.1\end{array}$ & 31.9 & 0.4 & & & 0.8 & 4..3 & 31.1 \\
\hline $2 \times m$ & 2.8 & 47.9 & 3.6 & 0.4 & & & 1.2 & 46.7 & 33.2 \\
\hline 2001 & 2.5 & 50.6 & 0.0 & OA & 0.5 & & 2.1 & 40.3 & 34.9 \\
\hline 20012 & 10 & 53.4 & 99.8 & 0.4 & 1.4 & & 3.9 & 49.3 & 35.9 \\
\hline נטגa & 3.0 & 56.4 & 42.4 & & נ. & & 6.9 & 49.5 & 35.5 \\
\hline 2006 & 30 & 39.4 & 45.1 & & $3 \boldsymbol{n}$ & & 9.9 & 49.5 & 35.2 \\
\hline 2005 & 3.6 & 62.9 & 47.9 & & 3.0 & & 12.9 & 50.0 & 35.0 \\
\hline 2006 & 3.2 & 66.1 & 50.4 & & 10 & 1.8 & 17.7 & 48.4 & 32.1 \\
\hline 200) & 3.9 & 200 & 53.4 & & 30 & 1.8 & 22.5 & 47.5 & 30.9 \\
\hline 2000 & 4.0 & 74.0 & 56.4 & & 30 & is & 21.3 & 46.7 & 29.1 \\
\hline 2014 & G. At & 18.0 & 59.4 & & 30 & 18 & 32.1 & 46.7 & 21.3 \\
\hline 2010 & 4.2 & 83.0 & 62.9 & & 30 & iso & 36.9 & 46.1 & 26.0 \\
\hline 2011 & 4.3 & 87.3 & 66.1 & & 3.0 & 30 & 42.9 & 4.4 & 23.2 \\
\hline 2012 & 4.1 & 91.4 & 700 & & 3.0 & 1.0 & 46.9 & 42.5 & 21.1 \\
\hline 2013 & 3.8 & 95.2 & 74.0 & & 3.0 & 30 & 34.9 & 40.3 & 19.1 \\
\hline 2014 & 6.3 & 99.5 & 78.8 & & 300 & 1.0 & 60.9 & 39.6 & 11.9 \\
\hline 2015 & 3.9 & 103.4 & 0 & & 3.0 & 3.0 & 66.9 & 36.5 & 16.1 \\
\hline 2016 & 4.0 & 101.4 & 87.3 & & 3.0 & 3.0 & 72.9 & 4.5 & 14.4 \\
\hline 2017 & 4.3 & 111.6 & 91.4 & & 30 & 100 & 78.9 & 32.1 & 12.5 \\
\hline 2018 & 4.2 & I1S & 95 & & $3 d$ & 3. & 84.9 & J1.0 & 10.3 \\
\hline 2019 & 4.3 & (2).1 & 99.5 & & 30 & 3.0 & 90.9 & 29.2 & 8.6 \\
\hline auzu & 4.5 & 124.6 & 103.4 & & 3.0 & 3.0 & 9.9 & 21.1 & 6.5 \\
\hline 2021 & & 124.6 & 107.4 & & 3.0 & 3.0 & 102.9 & 21.7 & 4.5 \\
\hline 2022 & & 124.6 & 111.6 & & 3.0 & 3.0 & 100.9 & 15.1 & 2.1 \\
\hline 21233 & & 124.6 & 115.9 & & 30 & 1.0 & 116.9 & 9.1 & 1.0 \\
\hline 21224 & & 126.6 & 120.1 & & 3.0 & 2.2 & 120.1 & 4.5 & n \\
\hline 2125 & & 124.6 & 124.6 & & 0.1 & 3.0 & 123.2 & 1.4 & 1.4 \\
\hline 2026 & & 124.6 & 124.6 & & & 1.4 & 124.6 & & \\
\hline
\end{tabular}


TABLE 2.1-2

ALTERNATE CASE WASTE ACCEPTANCE SCHEDULE

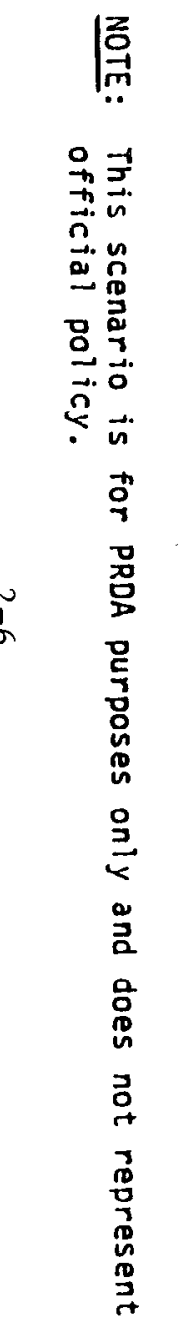

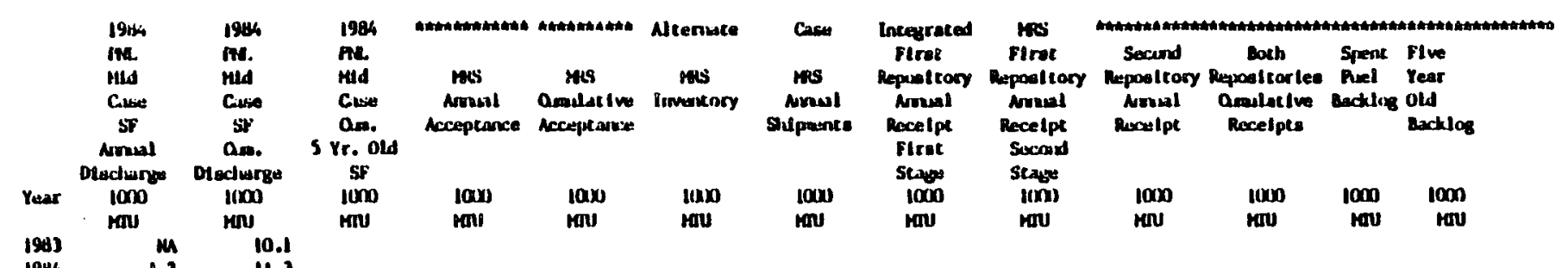

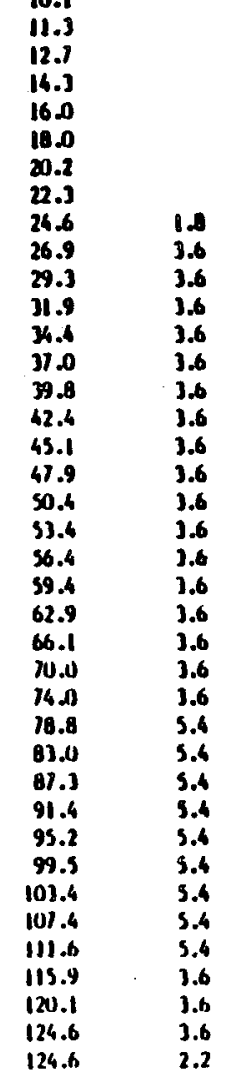

1.8
3.4
9.0
12.6
16.2
19.8
23.4
21.0
31.6
34.2
31.8
41.4
45.8
49.6
52.2
55.8
59.4
63.0
68.4
11.8
79.2
94.6
91.0
95.4
101.8
115.2
111.6
115.2
114.8
122.4
124.6

\begin{tabular}{|c|c|}
\hline $\begin{array}{l}8.00 \\
5.4\end{array}$ & $\begin{array}{l}0.0 \\
0.0\end{array}$ \\
\hline 0.6 & 0.4 \\
\hline 11.8 & 0.6 \\
\hline 150 & 0.4 \\
\hline 17.1 & 0.9 \\
\hline 19.5 & IA \\
\hline 20.1 & $\mathbf{3 . 0}$ \\
\hline 20.1 & 1.0 \\
\hline 21.3 & 1.0 \\
\hline 20.1 & 4.0 \\
\hline 18.9 & 4.8 \\
\hline 17.1 & 4.8 \\
\hline 16.5 & 4.8 \\
\hline 15.3 & 4.6 \\
\hline 12.9 & 6.0 \\
\hline 10.5 & 6.0 \\
\hline 8.1 & 60 \\
\hline 1.5 & $6, n$ \\
\hline 6.9 & 600 \\
\hline 6.J & 60 \\
\hline 5.7 & 60 \\
\hline 5.1 & 60 \\
\hline 4.5 & 6.0 \\
\hline 3.9 & 6.0 \\
\hline 3.3 & 6.0 \\
\hline 2.1 & 6.0 \\
\hline 0.3 & 60 \\
\hline 0 & 3.4 \\
\hline 0.5 & 3.1 \\
\hline $\boldsymbol{D}$ & 2.1 \\
\hline
\end{tabular}

0.4
0.6
0.4
0.4
0.4

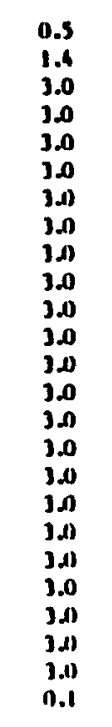

\begin{tabular}{|c|c|c|c|}
\hline & & $\begin{array}{l}33.2 \\
4.6\end{array}$ & $\begin{array}{l}22.8 \\
21.5\end{array}$ \\
\hline & 0.4 & 33.4 & 20.3 \\
\hline & 0.8 & 32.5 & 19.1 \\
\hline & 1.2 & 31.7 & 18.2 \\
\hline & 2.1 & 30.6 & 17.2 \\
\hline & 3.9 & 0.0 & 16.4 \\
\hline & 6.9 & 29.4 & 15.4 \\
\hline & 9.9 & $28 \mathrm{~A}$ & 14.5 \\
\hline & 12.9 & 24.1 & 13.1 \\
\hline 1.8 & 11.1 & 28.3 & 12.6 \\
\hline 1.8 & 22.3 & 28.6 & 12.0 \\
\hline 1.8 & 21.3 & 29.0 & il. \\
\hline 1.8 & 32.1 & $\mathbf{w} .2$ & 10.8 \\
\hline IA & $\times .9$ & ท.8 & 10.7 \\
\hline 3.0 & 42.9 & 31.5 & 10.3 \\
\hline 30 & 40.9 & $32 \Omega$ & 110.6 \\
\hline 3.0 & $\$ 4.9$ & 32.2 & 11.0 \\
\hline 3.0 & 60.9 & $\mathbf{3 1 . 1}$ & 10.4 \\
\hline 3.0 & 66.9 & 29.6 & 9.2 \\
\hline 3.0 & 12.9 & 28.2 & 8.1 \\
\hline נ. & 18.9 & 27.0 & 6.8 \\
\hline 3.0 & 84.9 & 25.9 & 3.2 \\
\hline 3.0 & 90.9 & 24.7 & 4.1 \\
\hline 3.0 & $\% .9$ & 23.8 & 2.6 \\
\hline 3.1) & IOI.9 & 18.4 & 1.2 \\
\hline 3.0 & IUI .9 & (3) & 0 \\
\hline 3.0 & 114.4 & 9.4 & 11.7 \\
\hline 11.9 & IIH.A & 3.0 & 1.3 \\
\hline 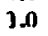 & 121.9 & 2.2 & 1.2 \\
\hline 2.7 & 124.6 & .0 & . \\
\hline
\end{tabular}




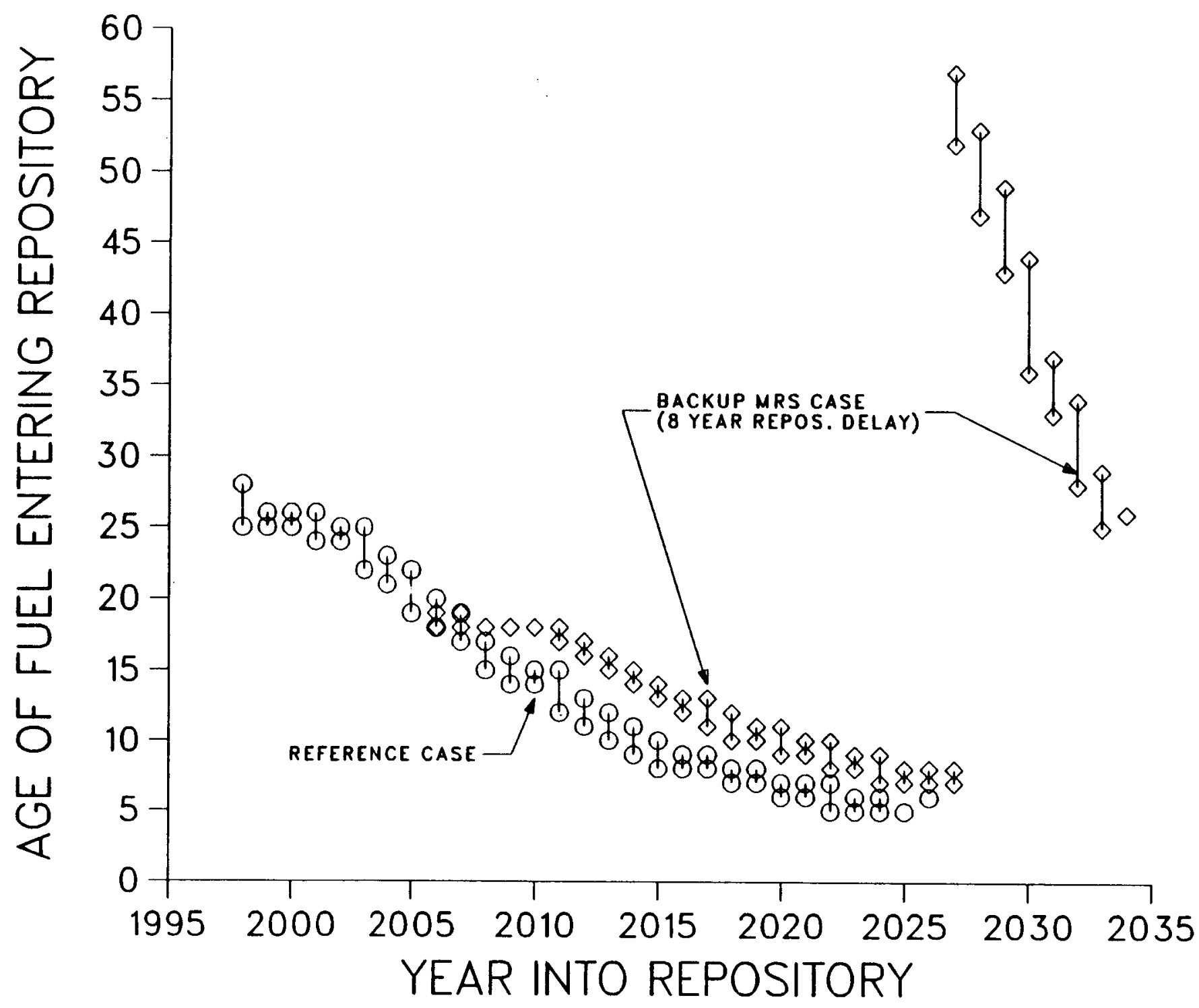

Fig. 2.1-1. Age of fuel into repository 
The destination and transfer strategy of fuel in the acceptance schedule can lead to dramatic discontinuities in the fuel age distribution, as is also illustrated in Fig. 2.1-1. The age distribution of fuel into the repository shown in this case is based on a 1998 backup MRS startup coupled with an assumed eight-year delay in the repository startup. Fuel is shipped to the MRS until 2006, after which fuel is shipped both to the MRS and to the delayed repository until 2019. After 2027, the oldest fuel from the MRS is transferred to the repository.

As indicated, in this case, the age of fuel going to the repository jumps from about 7 to 55 years. For this age transition the mean heat load for fuel transferred would decrease by a factor of three, which would result in a significant change in the choice and configuration of an optimum repository package. As discussed in section 2.4 of this report, an acceptance strategy based on an age-burnup equivalencing to more nearly levelize dose sources and heat loads would standardize and simplify package designs and storage or disposal operations.

Figure 2.1-2 shows the time variation in heat load for fuel of 33,000 MWd/MT burnup for the delayed repository fuel age distribution depicted in Fig. 2.1-1. This result suggests that alternative strategies related to age at acceptance or transfer should be investigated, particularly for scenarios related to an MRS followed by a delayed repository startup if a variation in heat load would complicate repository operations.

\subsubsection{Burnup/Age Impacts}

Table 2.1-3 reflects the actual and predicted spent fuel burnup and age at emplacement according to the waste acceptance schedule in Table 2.1-1. Table 2.1-3, as well as other inventory related data in this report, reflect a projected inventory of 124,300 MTU rather than the currently specified $124,600 \mathrm{MTU}$. The original inventory data 


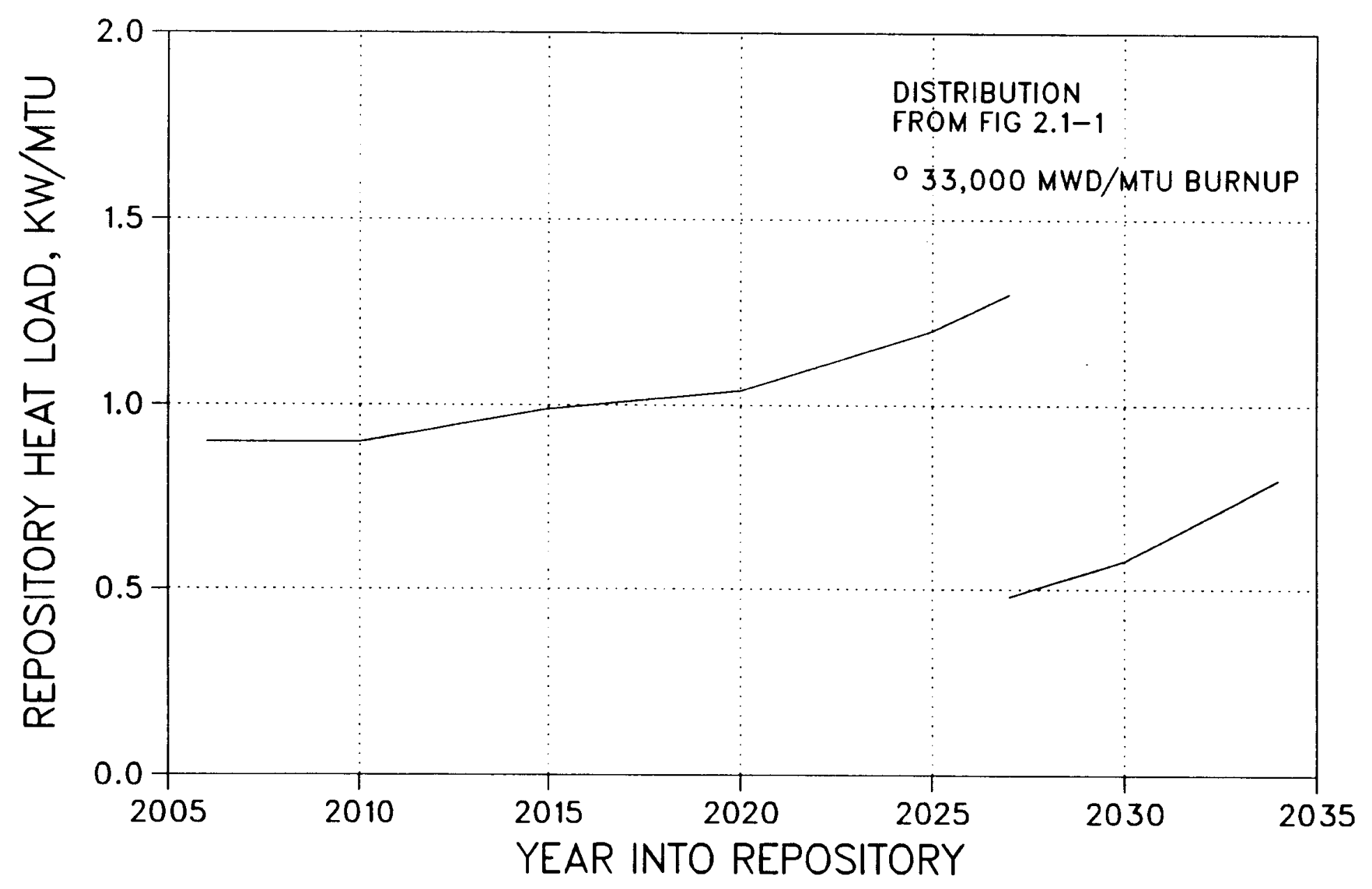

Fig. 2.1-2. Heat load into repository for backup MRS case with 8-year repository delay 
TABLE $2.1-3$

SPENT FUEL BURNUPS AND AGES AT EMPLACEMENT REFERENCE CASE - MTUS

\begin{tabular}{|c|c|c|c|c|c|c|c|c|c|c|}
\hline & $\begin{array}{l}\text { Discharge } \\
\text { rear }\end{array}$ & 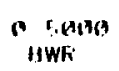 & $\begin{array}{c}\text { A. 5,09a } \\
\text { PWR }\end{array}$ & $\begin{array}{l}5000 \text { BWR } 16000 \\
\text { BWA }\end{array}$ & $\begin{array}{l}500 \Omega \text { - } 10000 \\
\text { PWR }\end{array}$ & $\begin{array}{c}10000-15000 \\
B W R\end{array}$ & $\begin{array}{c}10000-15000 \\
\text { PWR }\end{array}$ & $\begin{array}{c}15000-20000 \\
\text { BWR }\end{array}$ & $\begin{array}{c}15000-20000 \\
\text { PWR }\end{array}$ & $\begin{array}{c}20000-25000 \\
\text { BWR }\end{array}$ \\
\hline 1970 & 1910 & a & (B) & 0 & 0 & $a$ & 0 & 0 & 1 & a \\
\hline 1971 & 1911 & 0 & (9) & 3 & 0 & 3 & 0 & 0 & 1 & 0 \\
\hline 1972 & 1972 & 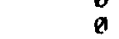 & $a$ & 10 & 0 & i & 0 & 4 & D & 0 \\
\hline 1973 & 1973 & 9 & b & 18 & 0 & 25 & 6 & 26 & 25 & 2 \\
\hline 1974 & 1974 & 35 & 1 & 1 & 0 & 150 & 89 & 13 & 0 & 4 \\
\hline 1975 & 1976 & 0 & 0 & 0 & 10 & 51 & 186 & 149 & 10 & 23 \\
\hline 1976 & 1976 & i & a & ค9 & c & 75 & 21 & 148 & 178 & 0 \\
\hline 1977 & 1977 & a & $a$ & $5:$ & D & 32 & 0 & 199 & 111 & 102 \\
\hline 1978 & 1978 & 6 & is & $i$ & o & 18 & 51 & 86 & 78 & 235 \\
\hline 1979 & 1979 & B & is & a & (1) & 11 & 29 & 92 & 117 & 160 \\
\hline 1980 & 1986 & 14 & 8 & $a$ & i1 & 2 & 4 & 48 & 24 & 433 \\
\hline 1981 & 1981 & 0 & 0 & 4 & $\because$ & 0 & 28 & 33 & 10 & 267 \\
\hline 1982 & 1982 & D & $B$ & $\because$ & $!$ & 0 & 11 & 47 & 89 & 14 \\
\hline 1983 & 1983 & 0 & $\theta$ & 10 & 12 & 12 & 8 & 3 & 87 & 88 \\
\hline 1984 & 1984 & 19 & 0 & in & a & 14 & 24 & 2 & 32 & 82 \\
\hline 1985 & 1985 & 0 & 8 & 21 & g & 59 & 24 & 16 & 50 & 31 \\
\hline 1985 & 1986 & 15 & 0 & 69 & 0 & 60 & 84 & 28 & 53 & 37 \\
\hline 1987 & 1987 & 21 & g & 36 & ठ & 16 & 74 & 71 & 84 & 151 \\
\hline 1988 & 1988 & 15 & $\bar{\theta}$ & 59 & 0 & 63 & 91 & $\theta 0$ & 110 & 86 \\
\hline 1989 & 1989 & 0 & 0 & 31 & 0 & 26 & 51 & 107 & 85 & 132 \\
\hline 1990 & 1990 & 0 & 0 & 0 & 0 & 41 & 41 & 82 & 5 & 62 \\
\hline 1991 & 1991 & 0 & 0 & 0 & 0 & 0 & 24 & 45 & o & 93 \\
\hline 1992 & 1992 & อ & 0 & 41 & ह & 39 & 58 & 2 & 28 & 87 \\
\hline 1993 & 1993 & 0 & 0 & 0 & 0 & 14 & B & 70 & 32 & 0 \\
\hline 1994 & 1904 & a & 0 & 60 & 0 & a & 24 & 2 & 55 & $120^{\circ}$ \\
\hline 1995 & igys & J & D & b & 0 & o & 0 & 45 & 0 & 72 \\
\hline 1996 & 1906 & $a$ & 0 & 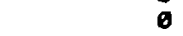 & 0 & 0 & 0 & 43 & 0 & 87 \\
\hline 1997 & 199 ! & $a$ & 0 & 30 & 0 & 0 & 0 & 2 & 0 & 55 \\
\hline 1998 & 1958 & $\therefore$ & a & 0 & 0 & 0 & 8 & 3 & 29 & 80 \\
\hline 1999 & 1.049 & $\leadsto$ & $"$ & ס & 0 & 0 & D & 47 & 30 & 58 \\
\hline 2000 & 2060 & $\because$ & a & 0 & 0 & 0 & 0 & 8 & 0 & 58 \\
\hline 2001 & 2001 & a & a & 34 & 0 & a & 0 & 2 & 0 & 78 \\
\hline 2002 & 2002 & 0 & is & 64 & 0 & 0 & (i) & 2 & 87 & 88 \\
\hline 2903 & 2083 & a & 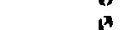 & 29 & 0 & 0 & a & 120 & 86 & 22 \\
\hline 2004 & 2004 & o & in & B6 & 0 & 3 & ) & 76 & 86 & 108 \\
\hline 2065 & 2005 & $\theta$ & 0 & 96 & 19 & 0 & 21 & 122 & 88 & 58 \\
\hline 2006 & 2006 & 0 & D & 52 & 0 & 0 & 0 & 108 & 114 & 22 \\
\hline 2007 & 2007 & 10 & 3 & 166 & 22 & b & 33 & 254 & 58 & 74 \\
\hline 2008 & 2008 & 23 & $\ddot{i}$ & 173 & 32 & 77 & 39 & 92 & 211 & 130 \\
\hline 2009 & 2009 & $\theta$ & $2 \ddot{\theta}$ & 339 & 148 & 63 & 139 & 334 & 315 & $\begin{array}{r}136 \\
85\end{array}$ \\
\hline 2010 & 2010 & 8 & 1 & 118 & 78 & 68 & $a$ & 240 & 438 & 85 \\
\hline 2011 & 2011 & 0 & 11 & 227 & 19 & 23 & 29 & 593 & 199 & 22 \\
\hline 2812 & 2012 & D & 12 & 68 & 4) & 0 & 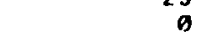 & 183 & 260 & 22 \\
\hline 2013 & $\begin{array}{l}2012 \\
2013\end{array}$ & 0 & 6 & 88 & ${ }_{0}^{41}$ & 26 & 24 & 239 & 195 & 44 \\
\hline 2014 & 2014 & 0 & 20 & $\begin{array}{l}80 \\
96\end{array}$ & 0 & ( & 67 & $\begin{array}{l}184 \\
184\end{array}$ & $\begin{array}{l}190 \\
286\end{array}$ & $\begin{array}{l}44 \\
22\end{array}$ \\
\hline 2815 & 2015 & 0 & 0 & 28 & 0 & (b & 0 & 112 & 138 & 22 \\
\hline 2016 & 2016 & g & 0 & 63 & $g$ & a & D & 184 & 56 & 44 \\
\hline 2017 & 2017 & 0 & : & 29 & 0 & 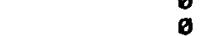 & ס & $\begin{array}{r}104 \\
42\end{array}$ & 84 & 22 \\
\hline 2018 & 2018 & 0 & 0 & 28 & 0 & 0 & 0 & 72 & 28 & 22 \\
\hline 2019 & 2619 & 0 & 8 & 62 & 0 & 8 & 6 & 43 & 58 & 44 \\
\hline 2020 & 2020 & 0 & g & 33 & 6 & $\theta$ & 6 & 80 & 28 & 22 \\
\hline
\end{tabular}


TABLE 2.1-3 (Continued)

\begin{tabular}{|c|c|c|c|c|c|c|c|c|c|}
\hline & 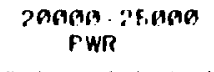 & $\begin{array}{c}2 ! .006-3090 A \\
\text { HWR }\end{array}$ & $\begin{array}{c}26000-3009 \theta \\
\text { PWR }\end{array}$ & $\begin{array}{c}30000-35000 \\
\text { BWR }\end{array}$ & $\begin{array}{l}\text { 36000-35000 } \\
\text { PWR }\end{array}$ & $\begin{array}{c}35009-10000 \\
B W R\end{array}$ & $\begin{array}{l}35000-40000 \\
\text { PWR }\end{array}$ & $\begin{array}{c}40600-45000 \\
B W R\end{array}$ & $\begin{array}{l}\text { 46000- } 45006 \\
F W R\end{array}$ \\
\hline 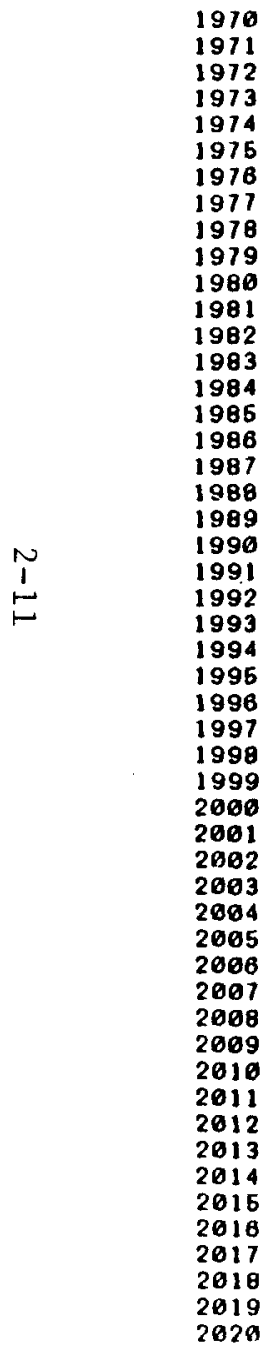 & 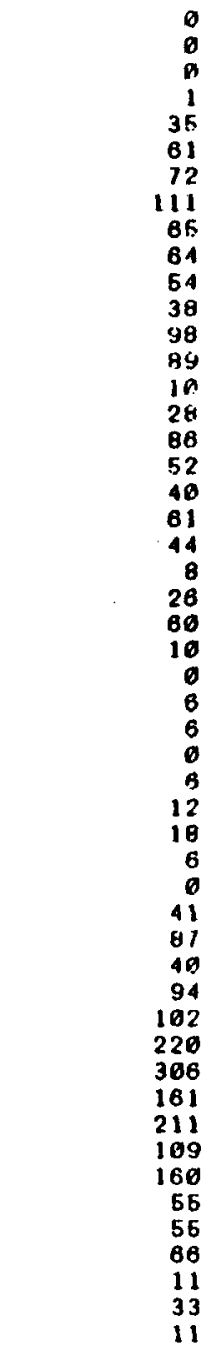 & $\begin{array}{r}6 \\
42 \\
98 \\
1 \\
23 \\
45 \\
6 \\
1 \\
26 \\
179 \\
94 \\
158 \\
251 \\
375 \\
298 \\
319 \\
490 \\
333 \\
421 \\
354 \\
378 \\
594 \\
472 \\
626 \\
515 \\
642 \\
646 \\
683 \\
768 \\
586 \\
119 \\
511 \\
732 \\
630 \\
566 \\
196 \\
6204 \\
973 \\
591 \\
566 \\
634 \\
684 \\
591 \\
497 \\
684 \\
422 \\
623 \\
569 \\
593 \\
629 \\
361\end{array}$ & $\begin{array}{r}0 \\
16 \\
17 \\
21 \\
32 \\
23 \\
16 \\
122 \\
319 \\
251 \\
217 \\
237 \\
71 \\
226 \\
226 \\
219 \\
112 \\
131 \\
248 \\
236 \\
126 \\
139 \\
125 \\
99 \\
187 \\
219 \\
91 \\
89 \\
125 \\
15 \\
126 \\
133 \\
92 \\
86 \\
199 \\
114 \\
166 \\
154 \\
112 \\
295 \\
199 \\
203 \\
411 \\
176 \\
226 \\
176 \\
116 \\
196 \\
72 \\
122 \\
73\end{array}$ & 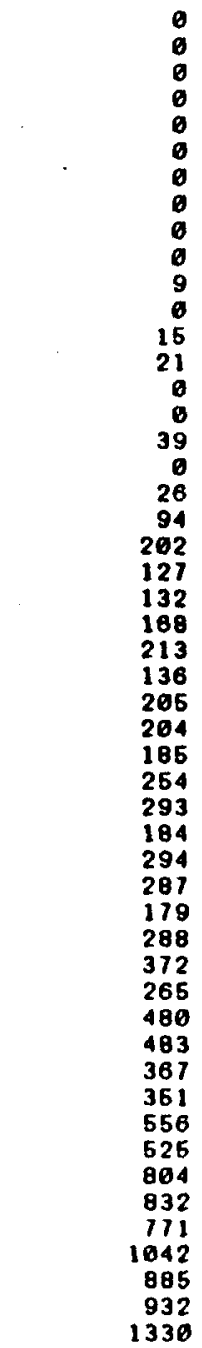 & 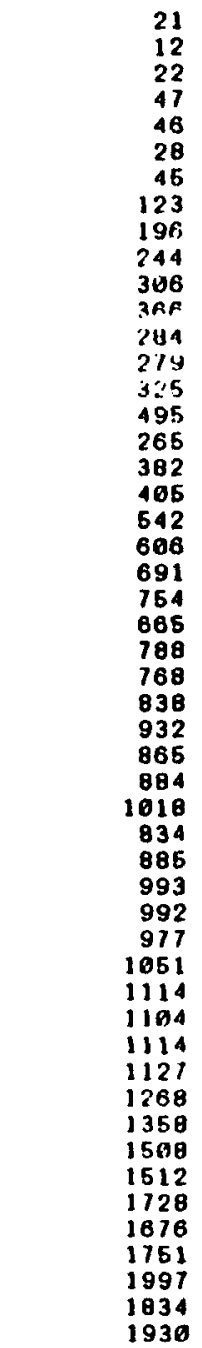 & $\begin{array}{l}0 \\
0 \\
0 \\
0 \\
0 \\
0 \\
0 \\
0 \\
0 \\
0 \\
0 \\
0 \\
0 \\
0 \\
0 \\
0 \\
0 \\
0 \\
0 \\
0 \\
0 \\
0 \\
0 \\
0 \\
0 \\
0 \\
0 \\
0 \\
0 \\
0 \\
0 \\
0 \\
0 \\
0 \\
0 \\
0 \\
0 \\
0 \\
0 \\
0 \\
0 \\
0 \\
0 \\
0 \\
0 \\
0 \\
0 \\
0 \\
0 \\
0 \\
0 \\
0 \\
0 \\
0\end{array}$ & $\begin{array}{r}0 \\
0 \\
6 \\
6 \\
6 \\
6 \\
6 \\
7 \\
79 \\
43 \\
23 \\
52 \\
133 \\
153 \\
128 \\
166 \\
263 \\
334 \\
359 \\
318 \\
469 \\
428 \\
446 \\
644 \\
531 \\
536 \\
647 \\
655 \\
582 \\
698 \\
499 \\
666 \\
656 \\
661 \\
565 \\
639 \\
612 \\
549 \\
687 \\
596 \\
413 \\
398 \\
330 \\
278 \\
363 \\
258 \\
299 \\
345 \\
310 \\
295 \\
327\end{array}$ & $\begin{array}{l}0 \\
0 \\
0 \\
0 \\
0 \\
0 \\
0 \\
0 \\
0 \\
0 \\
0 \\
0 \\
1 \\
0 \\
0 \\
0 \\
0 \\
0 \\
0 \\
0 \\
0 \\
0 \\
0 \\
0 \\
0 \\
0 \\
0 \\
0 \\
0 \\
0 \\
0 \\
0 \\
0 \\
0 \\
0 \\
0 \\
0 \\
0 \\
0 \\
0 \\
0 \\
0 \\
0 \\
0 \\
0 \\
0 \\
0 \\
0 \\
0 \\
0 \\
0 \\
0 \\
0\end{array}$ & $\begin{array}{r}0.00 \\
6.00 \\
0.00 \\
0.00 \\
0.00 \\
0.06 \\
0.00 \\
0.00 \\
9.00 \\
0.00 \\
2.00 \\
0.46 \\
4.00 \\
0.00 \\
3.00 \\
28.00 \\
17.00 \\
16.00 \\
70.00 \\
57.00 \\
99.00 \\
100.00 \\
118.00 \\
71.00 \\
68.00 \\
81.00 \\
81.00 \\
81.00 \\
94.00 \\
71.00 \\
70.00 \\
84.00 \\
94.00 \\
76.00 \\
59.00 \\
77.00 \\
80.00 \\
93.00 \\
89.00 \\
129.00 \\
118.00 \\
81.00 \\
64.00 \\
85.00 \\
100.00 \\
130.00 \\
95.00 \\
156.00 \\
156.00 \\
215.00 \\
193.00\end{array}$ \\
\hline
\end{tabular}


TABLE 2.1-3 (Continued)

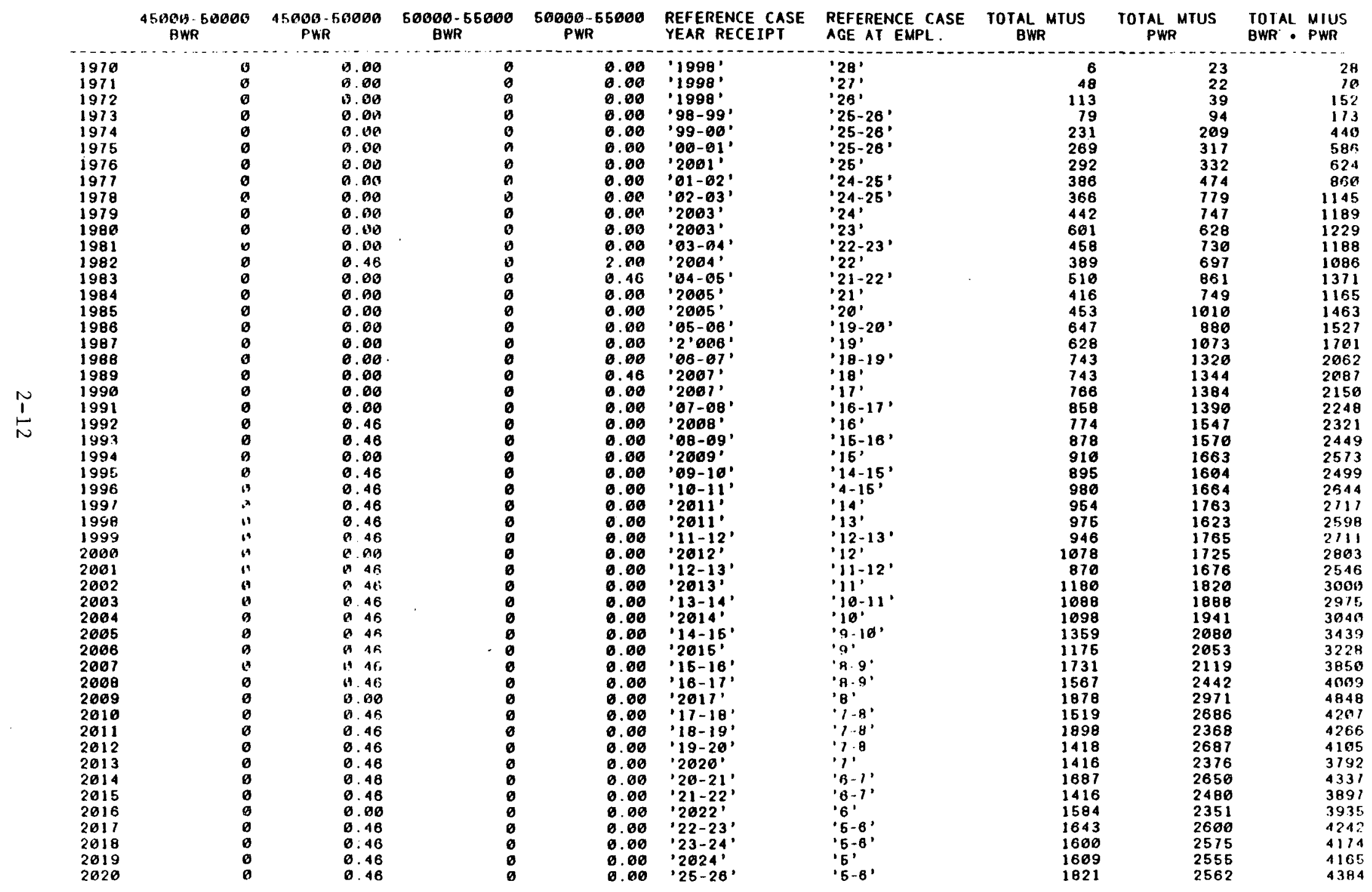


TABLE $2 \cdot 1-3$ (Continued)

CIMMII AIIVF N:.AS BWR P PWR

\begin{tabular}{|c|c|}
\hline 1970 & $2 \mathrm{H}$ \\
\hline 1971 & $9 H$ \\
\hline 1973 & $4=4$ \\
\hline 1974 & 86. \\
\hline 1915 & 1449 \\
\hline 1976 & 2973 \\
\hline 1977 & 2933 \\
\hline 1978 & 4078 \\
\hline 1979 & $(256)$ \\
\hline 1980 & 6496 \\
\hline 1981 & $: 684$ \\
\hline 1982 & 8116 \\
\hline $\begin{array}{l}1983 \\
1984\end{array}$ & $\begin{array}{l}10191 \\
11306\end{array}$ \\
\hline 1985 & $\begin{array}{l}12769 \\
\end{array}$ \\
\hline 1986 & 14296 \\
\hline $\begin{array}{l}1987 \\
1988\end{array}$ & 15991 \\
\hline $\begin{array}{l}1988 \\
1989\end{array}$ & $\begin{array}{r}18639 \\
20146\end{array}$ \\
\hline 1990 & 22296 \\
\hline $\begin{array}{l}1991 \\
1992\end{array}$ & $\begin{array}{l}24544 \\
26865\end{array}$ \\
\hline 1993 & 29314 \\
\hline 1994 & 31887 \\
\hline 1995 & 34386 \\
\hline 1996 & 31030 \\
\hline 1997 & 39741 \\
\hline 1998 & 42345 \\
\hline 1994 & 45.056 \\
\hline 2000 & 4745.7 \\
\hline 2001 & 5DAUE \\
\hline 2002 & 534A5 \\
\hline 2003 & $6638 \mathrm{~B}$ \\
\hline 2004 & 594214 \\
\hline 2005 & $6285: 0$ \\
\hline 2008 & P6n8। \\
\hline 2007 & $69 ! 3$, \\
\hline 2008 & 13346 \\
\hline 2009 & 18194 \\
\hline 2010 & 83001 \\
\hline 2011 & 87267 \\
\hline 2012 & 91372 \\
\hline 2013 & 95164 \\
\hline 2014 & 99501 \\
\hline 2015 & 163398 \\
\hline 2016 & 107333 \\
\hline 2017 & 111675 \\
\hline 2018 & 115749 \\
\hline 2019 & 119914 \\
\hline 2026 & 124298 \\
\hline
\end{tabular}


provided by PNL to GA was based on the 124,300 MTU value, but was later revised to the slightly higher value.

The projected burnup distribution over time for the reference PRDA inventory assumption, as provided by PNL, is illustrated in Fig. 2.1-3. The graphs show the fractional inventory less than the indicated burnup value for all fuel discharged through the indicated years. As can be seen, the mean burnup distribution in the earlier years of discharges, e.g., prior to 1986, is relatively low. The projected burnup distributions after 1985 show some burnup extension but not dramatic increases. Figures 2.1-4 through 2.1-6 show typical annual burnup distributions for selected years which, in combination with the cumulative discharge metric ton quantities, was used to make up the cumulative inventory results shown in Fig. 2.1-3.

Combinations of burnup and age result in a time distribution of the shielding source terms and heat load for fuel to be transported to, and handled at, the MRS and the repository. As discussed in Appendix A, the heat load and gamma shielding source terms have a similar age sensitivity, and both may accurately be assumed to be proportional to burnup. The neutron dose distribution, which would impact transport shielding design, has a lower age dependence but a much stronger burnup dependence.

Figures 2,1-7 and 2,1-8 show the time-phased cumulative inventory fraction below the indicated neutron dose and heat load, respectively, based on a 1998 MRS or repository startup acceptance schedule. These cumulative distributions result from the previously discussed burnup and age distributions coupled with the appropriate equations given in Appendix A to convert inventory by burnup/age to inventory dose or heat load distributions. The equivalent gamma source distribution is shown on Fig. 2.2-4. The figures are based on "age at transfer" to DOE which will occur at each reactor site according to the reference or alternate acceptance schedules given in Tables 2.1-1 and 2.1-2. 


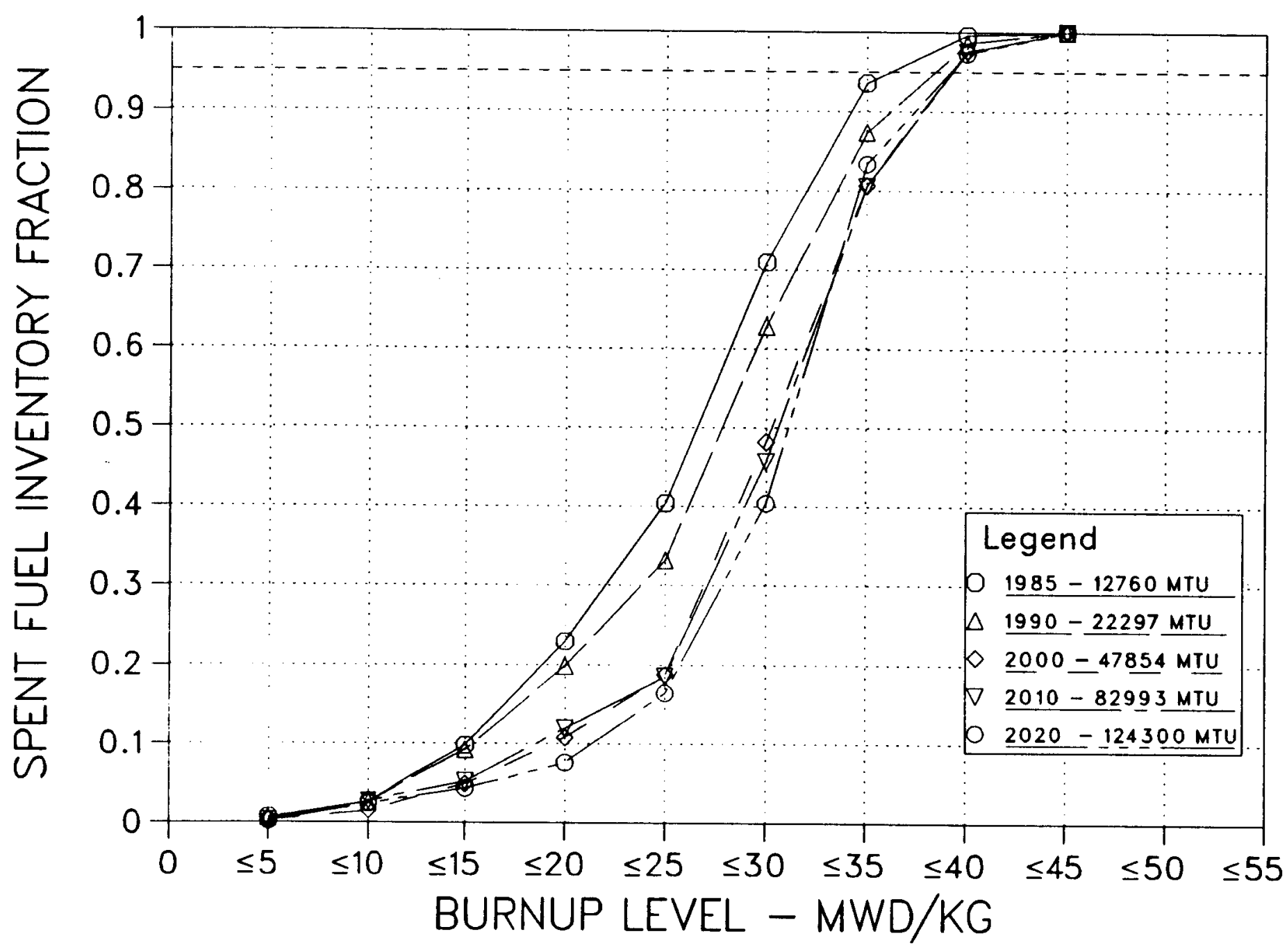

Fig. 2.1-3. Burnup level for fuel discharged up to indicated years 


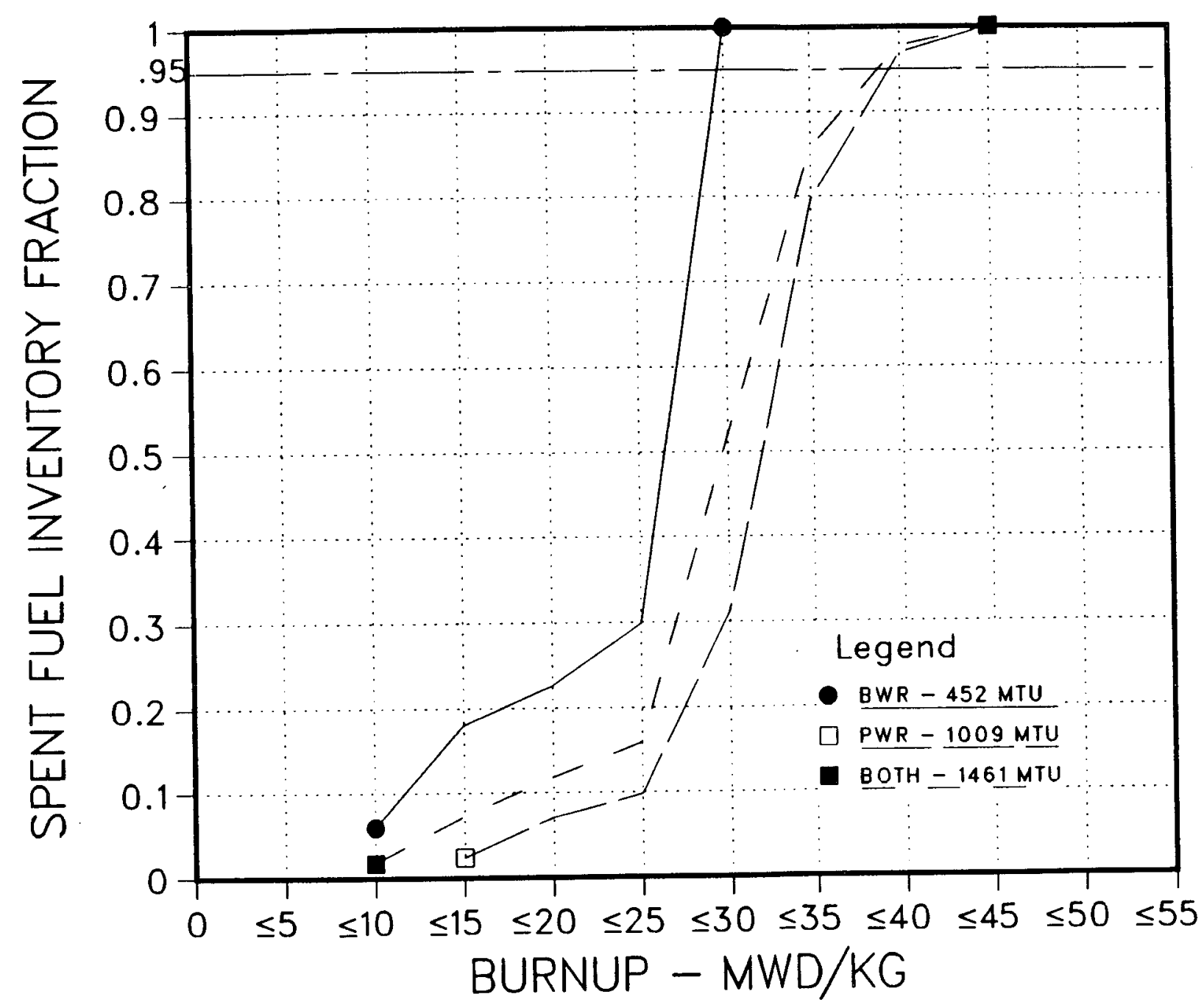

Fig. 2.1-4. Burnup level for fuel discharged in year 1985 


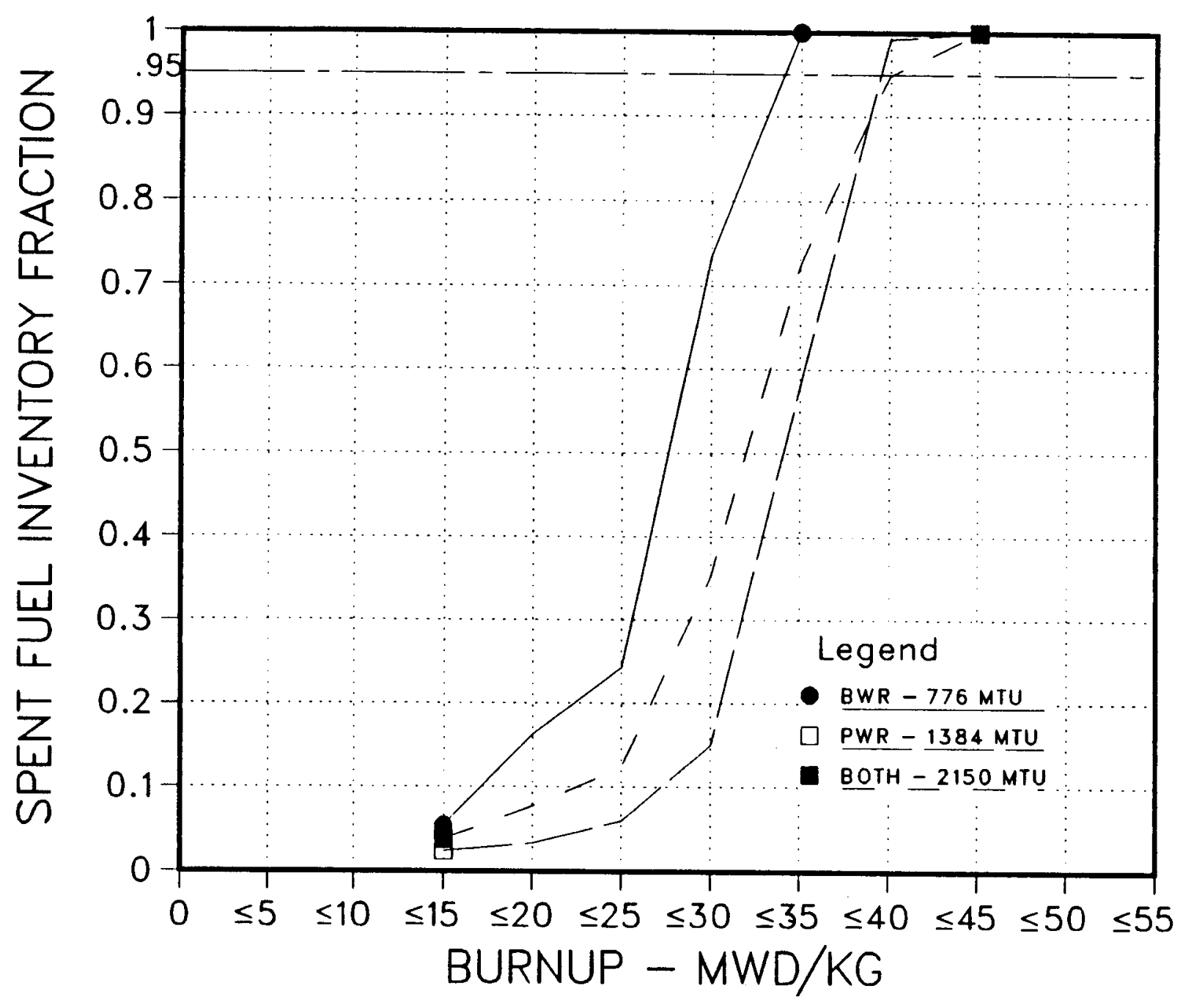

Fig. 2.1-5. Burnup level for fuel discharged in year 1990 


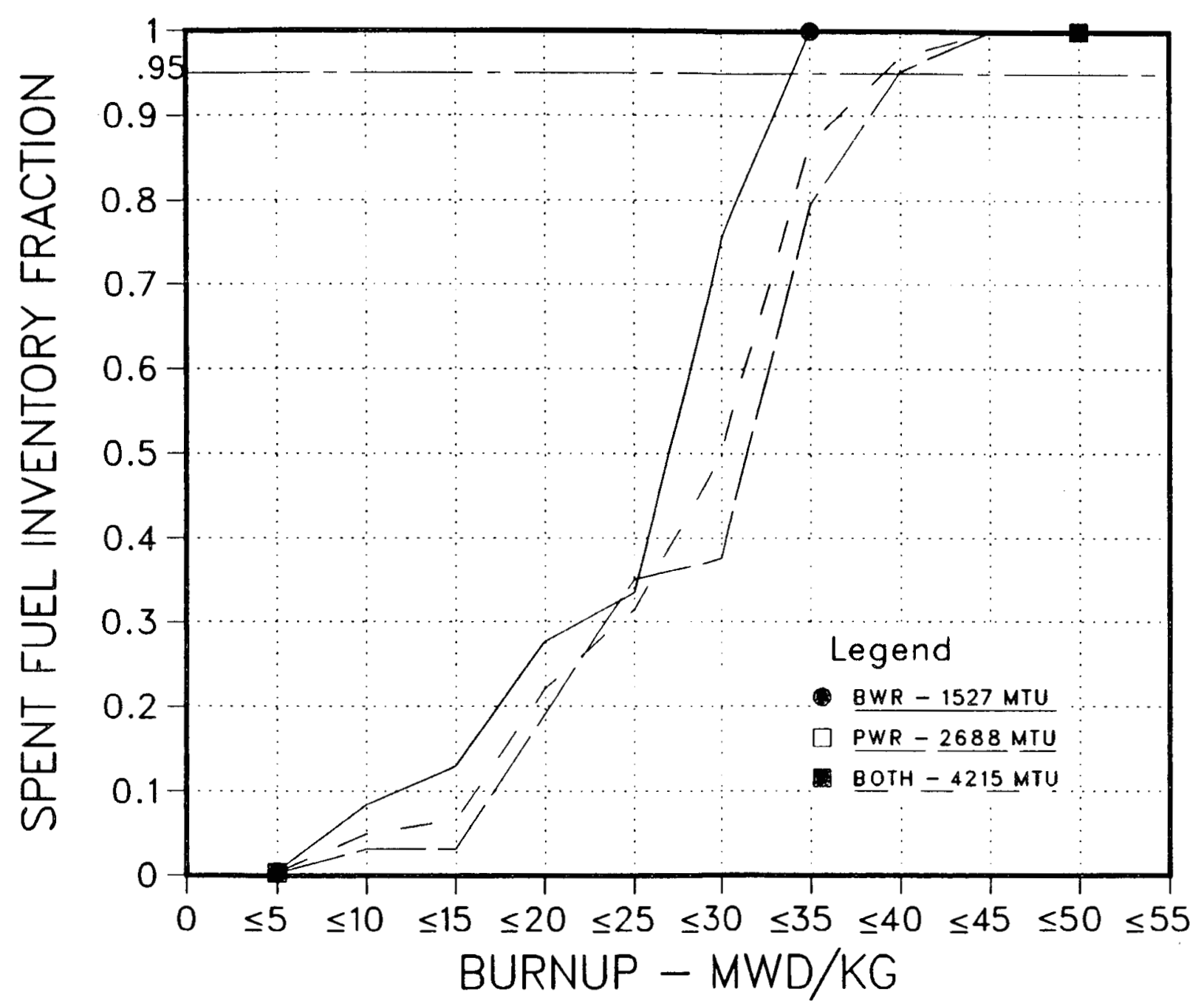

Fig. 2.1-6. Burnup level for fuel discharged in year 2010 


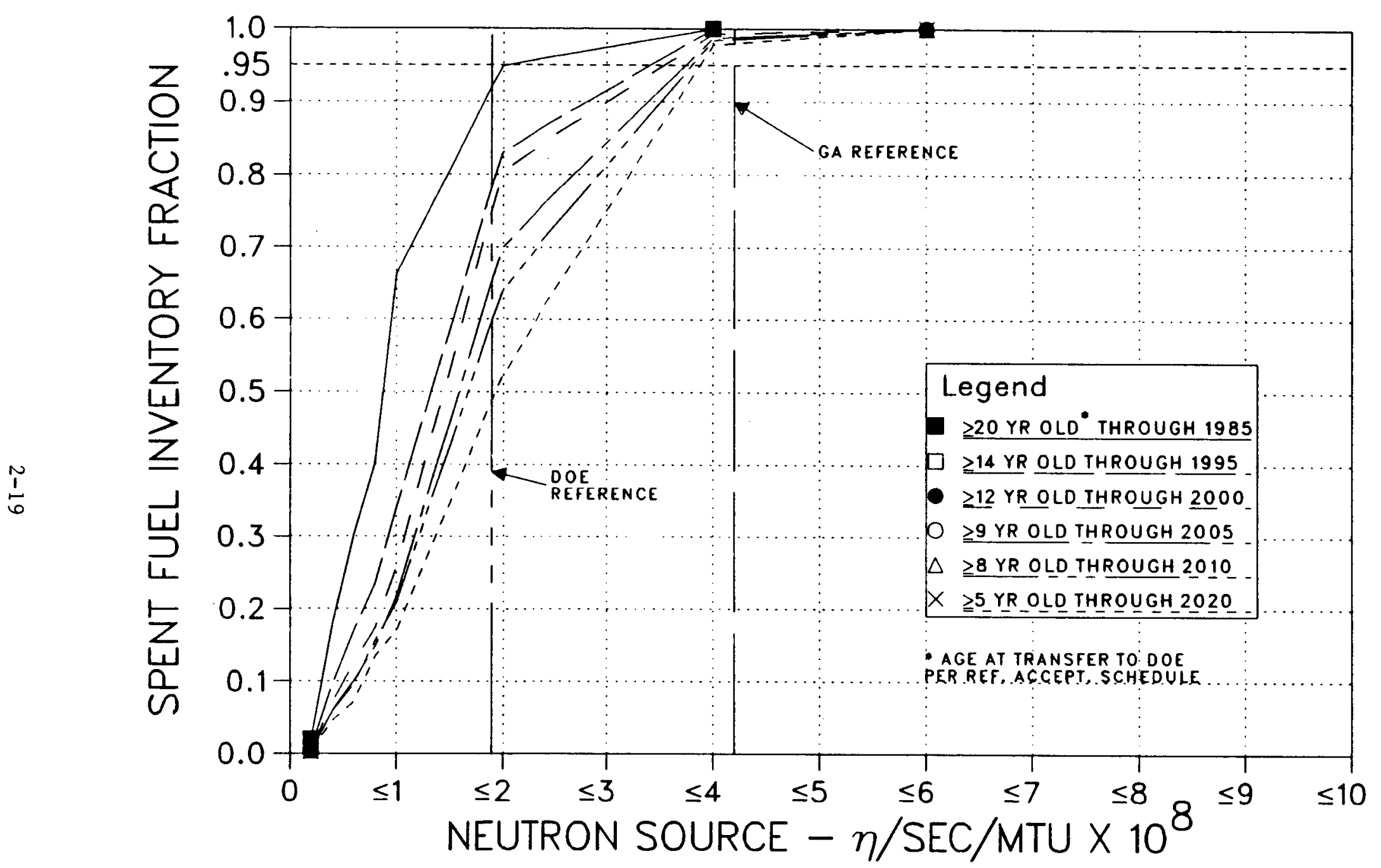

Fig. 2.1-7. Neutron source distribution for reference fuel burnup 


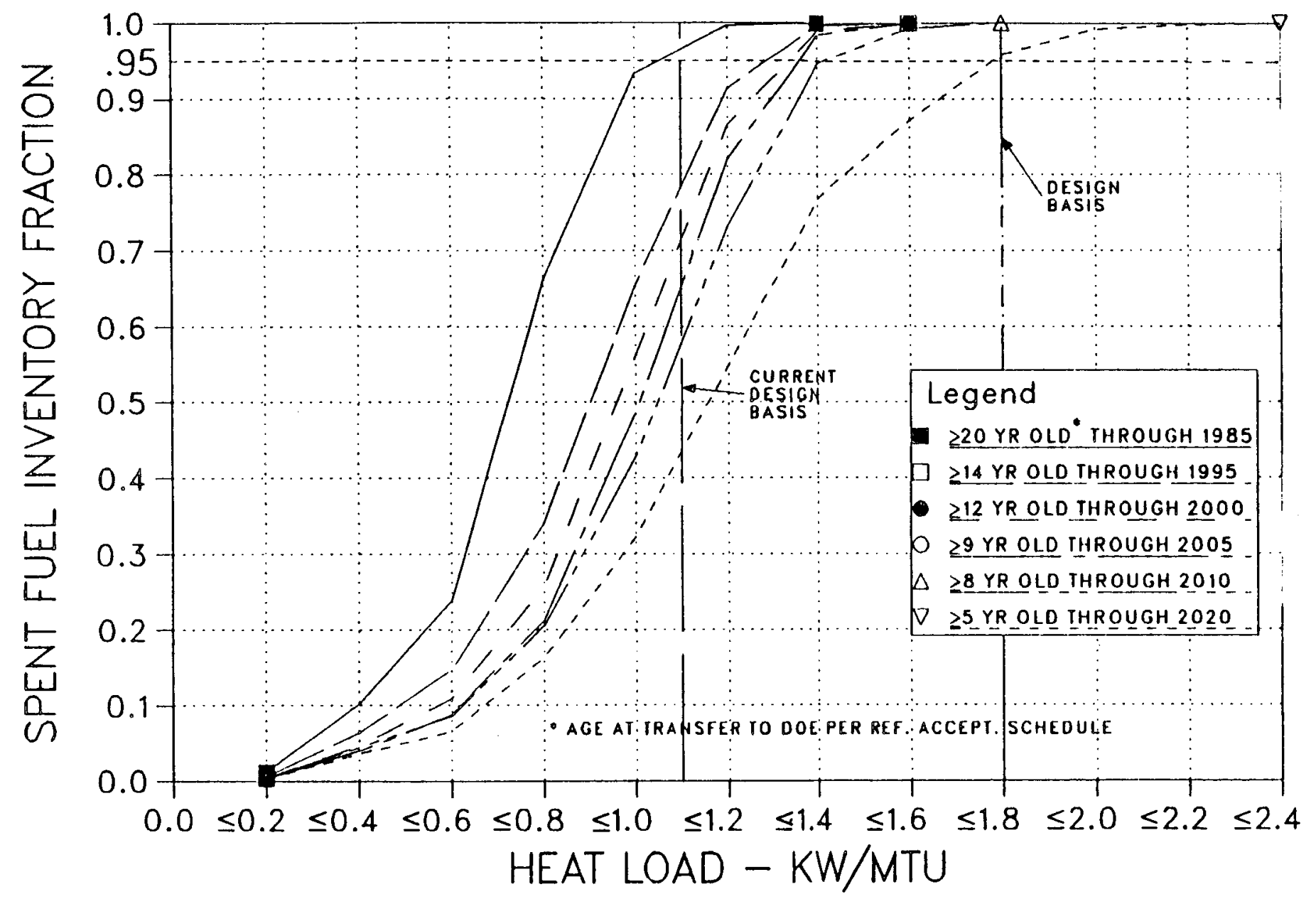

Fig. 2.1-8. Heat load distribution for reference fuel burnup 
The values of $1.1 \mathrm{~kW} / \mathrm{MTU}$ for the heat load and $1.9 \times 10^{8} \mathrm{n} / \mathrm{sec}-\mathrm{MTU}$ are indicated in the two figures and represent the appropriate values for the nominally assumed reference fuel of 33,000 MWd/MTU burnup and 10-year decay. As indicated, the nominal design value heat load specification overall covers approximately $50 \%$ of the total inventory into the repository or MRS. The nominal specification also results in about the same inventory capability from a neutron dose standpoint as would apply for the transportation system.

As previously noted, the recommended values used for the neutron dose (transportation) and heat load (storage) for the universal canister system elements were based on a capability for handling 40,000 MWd/MTU at 7 years decay for which the recommended values were $1.8 \mathrm{~kW} / \mathrm{MTU}$ and $4.25 \times 10^{8} \mathrm{n} / \mathrm{sec}-\mathrm{MTU}$ and which results in a $\geq 95 \%$ inventory capability.

The time-phased heat load distribution for an assumed 1996 MRS facility startup for which the fuel is aged about two years less than for a 1998 startup assumption was also considered. By comparing this result with the result shown in Fig. $2 \cdot 1-8$, it was found that there is a few percent ( $3 \%$ to $4 \%$ ) inventory capability reduction for the DOE nominal heat load basis if the earlier startup date is assumed. A similar modest shift was also obtained for the neutron dose distribution.

As discussed in Section 2.3, an increase in the projected burnup has a much greater impact than the impact due to a two-year-earlier facility startup date assumption.

\subsection{IMPACT OF BURNUP AND AGE ON DESIGN BASIS}

A statistical analysis of the reference PRDA inventory characteristics as supplied by PNL was carried out to determine the time-phased inventory fraction with less than a given calculated shielding source term (gamma and neutron source) and heat load. The source terms and heat load distributions were determined as a combined function of the 
burnup distribution in the inventory projection and the decay age distribution at the time of transfer from the reactor sites.

Figure 2.2-1 shows the time-phased burnup distribution expected for the reference PRDA inventory over two time intervals, i.e., for discharges through 1985 and through 2020. Figure 2.2-2 shows the cumulative fractional distribution of the age of fuel to be shipped over the time-phase for a repository or MRS startup in 1998 or into an integrated RS starting in 1996. Time-phased burnup and age distribution were used to calculate shielding source term(s) and heat-load inventory distributions to define the overall inventory-imposed design constraints both on the proposed universal canister waste system and on other systems as well. The impact of extended burnup, over and above that assumed in the PNL inventory data base, as proposed in certain EIA studies, was also assessed and is discussed in Section 2.3. As detailed in Appendix A, the heat load and shielding source terms were determined as a function of the time-phased inventory burnup interval distributions and the appropriate cooling age at the time of assumed transfer. The details of the equations used for defining the source terms and heat load as a function of burnup and decay age are given in Appendix A. These simplistic, but sufficiently accurate, equations are valid for cooling times of two years to 20 or more years and in general yield an accurate estimate, or a slight overestimate, of the source terms or heat loads. The equation fits to the available actual data, based on a heat load or shielding source term per MTU, were picked to better fit the PWR data, since the actual PWR values are somewhat higher than BWR values for a given burnup and decay age.

Figures 2.2-3 and 2.2-4 show summary curves of the total cumulative fractional inventory for discharges through the year 2020 as a function of the fissile enrichment and the gamma source strength distribution over several time phases. The gamma source represents the inventory status through the year 2025 and implicitly includes the appropriate distributions for all prior discharges and transfers at the time of 


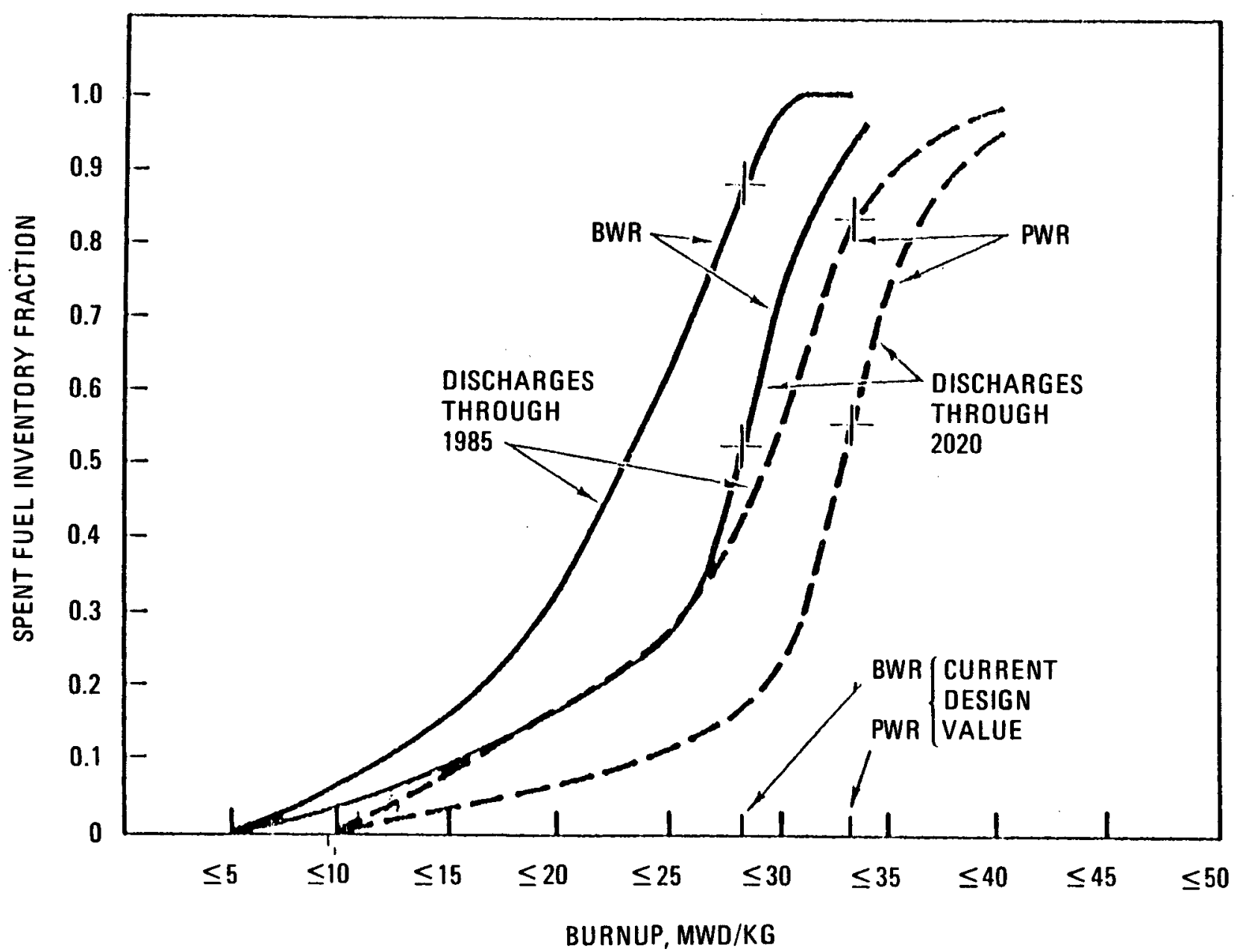

Fig. 2.2-1. Fue1 burnup distributions: 1985 versus 2020 


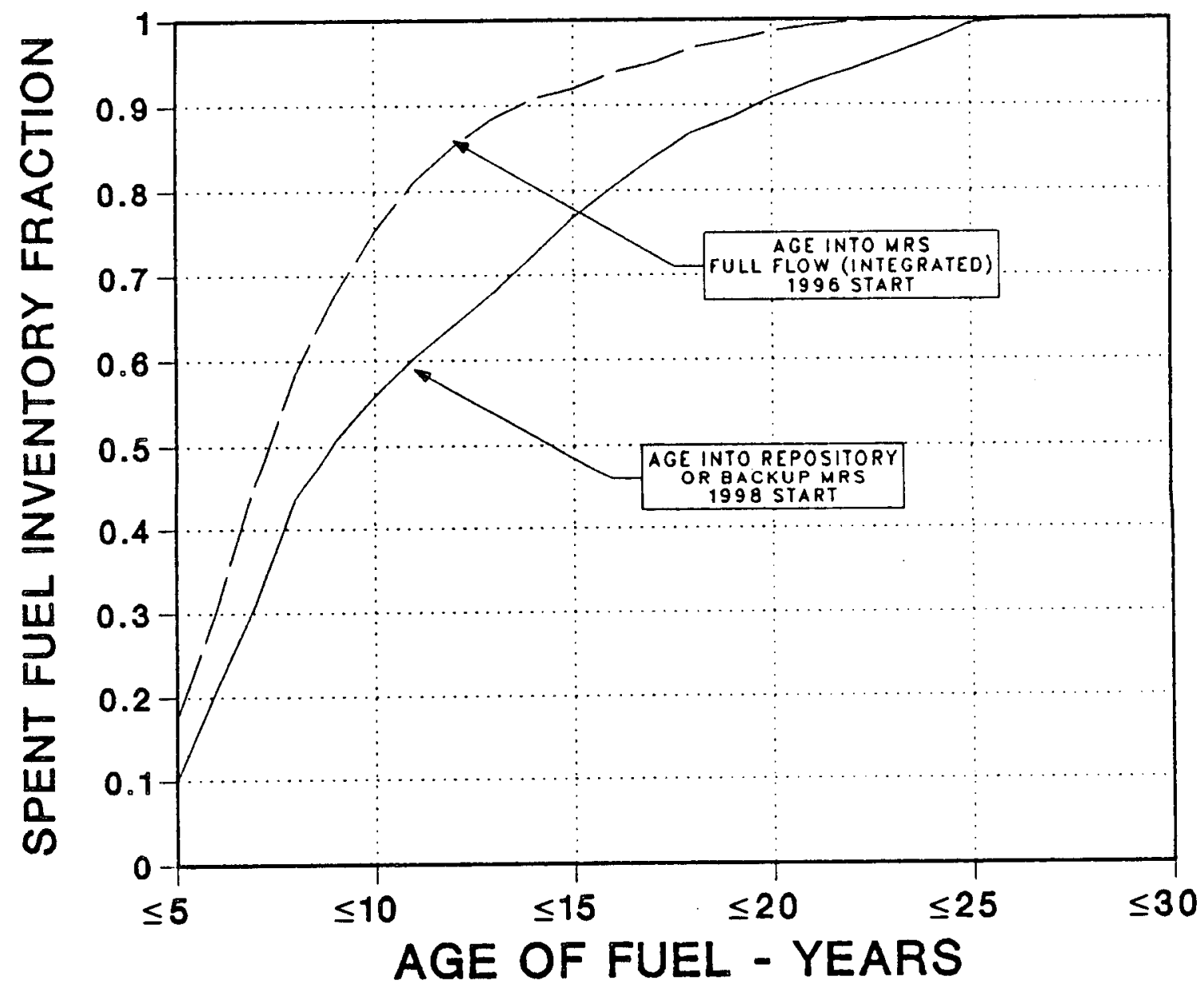

Fig. 2.2-2. Age distribution of spent fuel transfers for discharges through 2020 


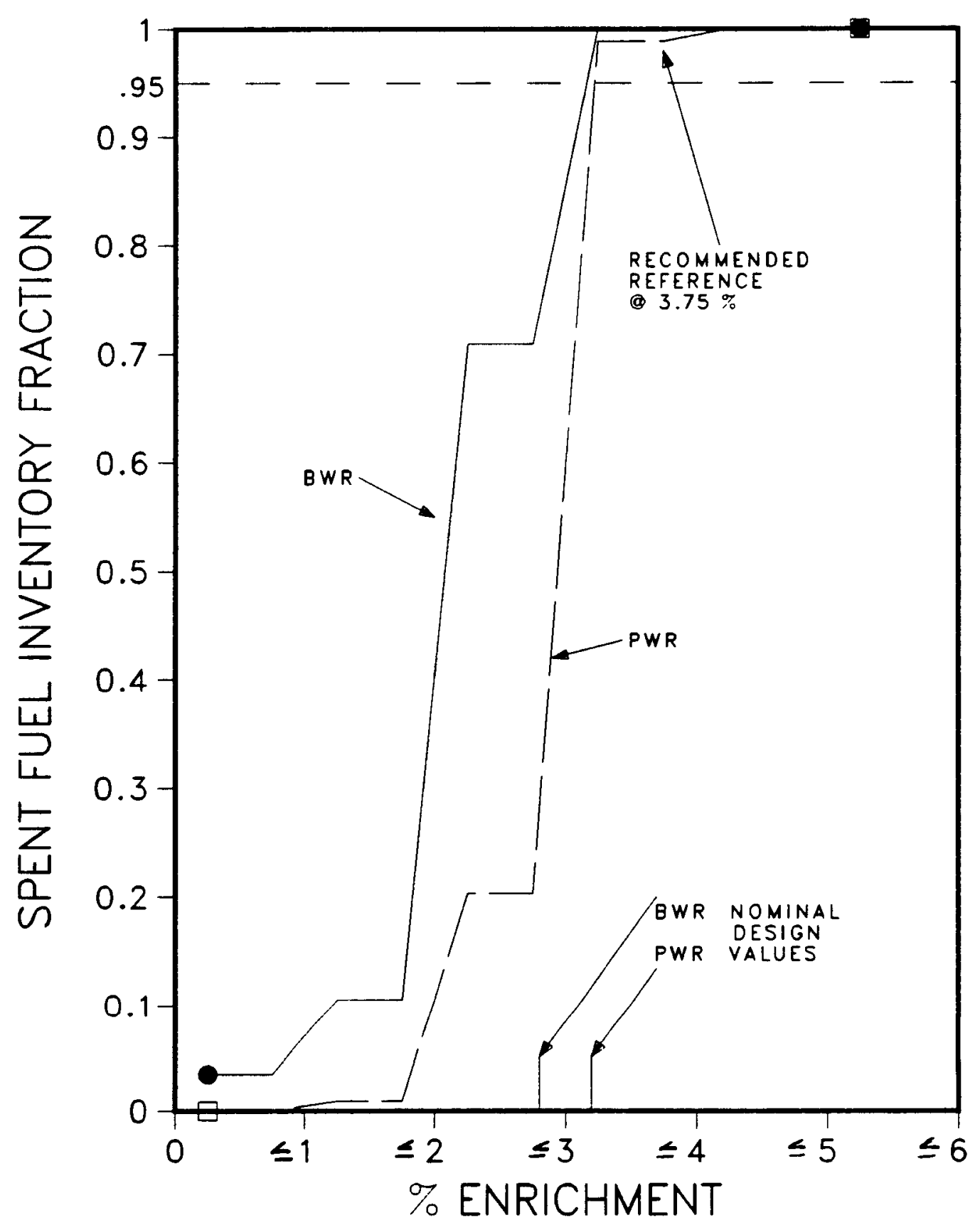

Fig. 2.2-3. Enrichment of fuel discharged up to 2020 


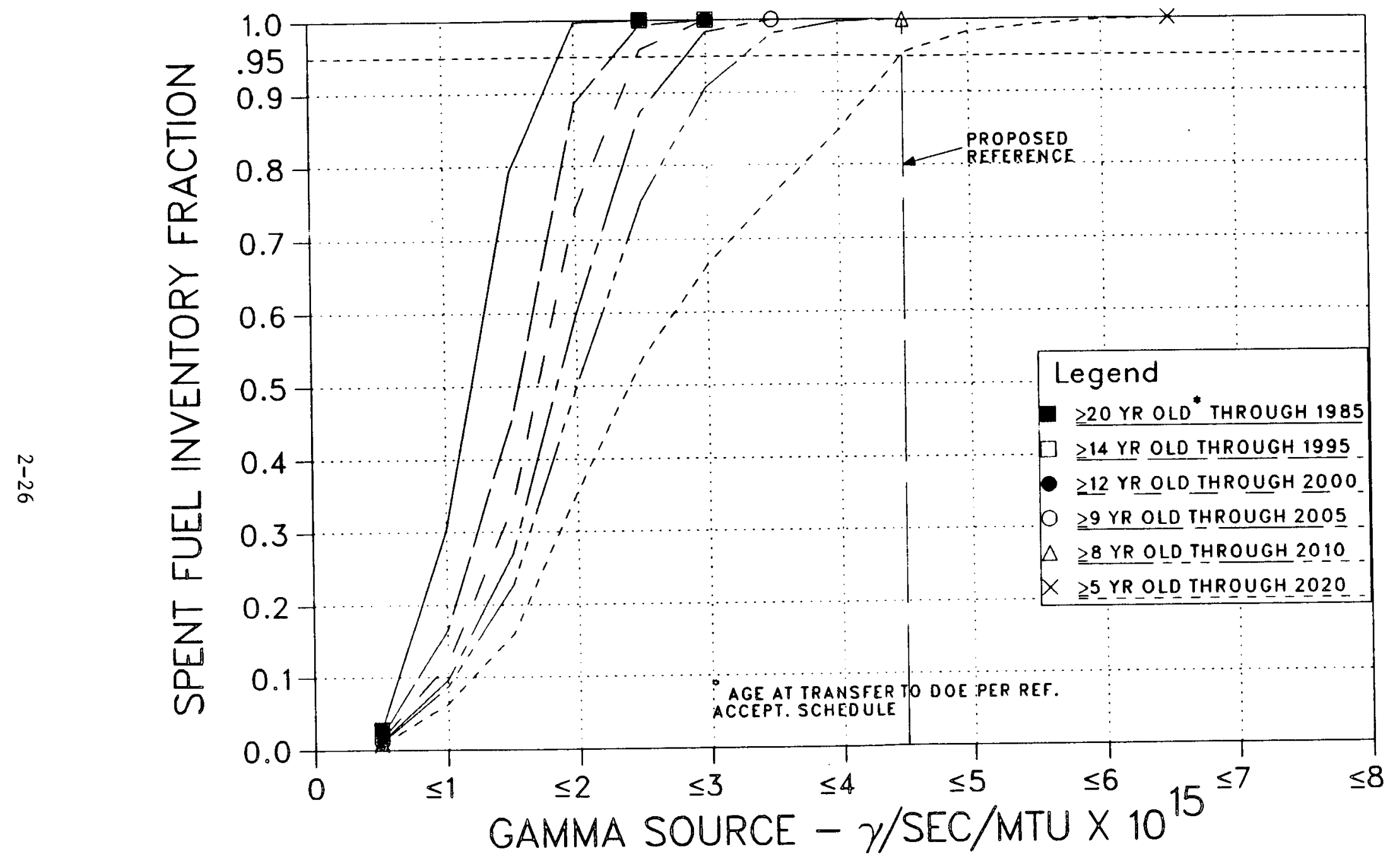

Fig. 2.2-4. Gamma source distribution for reference fuel burnup 
transfer to a MGR or MRS with startup in 1998 as well as the last discharges from reactor operations in the year 2020, which would be only about five years decayed when shipped from the reactors in the year 2025 .

As noted, the proposed universal canister design criteria are expected to result in a $95 \%$ to $98 \%$ inventory handling capability for the reference PRDA inventory assumptions. The proposed criteria would also result in a $95 \%$ or greater capability for a 1996 MRS facility startup date assumption.

In summary, the analysis of the time-phased inventory characteristics leads to the following inventory-imposed design criteria for a $>95 \%$ inventory capability system:

- Unburned fissile fuel enrichment 1imit of $3.75 \% \mathrm{U}-235$ to meet $k_{\text {eff }} \leq 0.95$.

- Heat load $=1.8 \mathrm{~kW} / \mathrm{MTU}$ limit to yield fuel centerline temperature limit $\leq 375^{\circ} \mathrm{C}$ for consolidated rod loadings.

- Direct neutron shielding source $=4.25 \times 10^{8} \mathrm{n} / \mathrm{sec} / \mathrm{MTU}$ for consolidated rod loadings.

- Direct gamma shielding source $=4.5 \times 10^{15} \mathrm{MeV} / \mathrm{sec} / \mathrm{MTU}$ for consolidated rod loadings.

As discussed later, these limits are consistent with a capability for handling consolidated fuel of up to $40,000 \mathrm{MWd} / \mathrm{MTU}$ burnup at 7 years cooling or equivalent.

It is important to note that the proposed system employing either a single overweight truck canister, a single larger rail canister, or six truck-type canisters that would comprise a rail cask system would 
Incorporate a transport or storage system shielding design based on the above design criteria with consolidated rods in all missions considered. Less than $5 \%$ of all shipments from reactors to the MGR (or MRS) are expected to be as consolidated rods based on the functions described for the first repository in the March 6, 1985 PRDA analysis assumptions (Ref. 1-1). The proposed rail transport cask, with shielding for consolidated rod loadings per the design criteria, would have a loaded weight of less than 100 tons with assembly loadings.

For the very limited shipments of consolidated rods from the reactor sites the proposed rail cask would be weight limited to less than the full consolidated rod loading of $36 \mathrm{PWR} / 72$ BWR. However, the shielding design, based on consolldated rod loadings, would allow essentially a $100 \%$ inventory transfer capability under the 100-ton weight limit for assembly shipments from the reactor sites to either the MRS or MGR. A storage cask or module design based on the same consolidated rod loadings and design criteria would be utilized so that a high inventory handling capability results for all missions. The same rail transport cask could be used at the MRS or the MGR for interim storage if necessary and the same cask could be used for transporting consolidated rods from the MRS to the MGR when full-scale consolidated rod shipping is required. With the proposed system it would be feasible to perform rod consolidation at fuel arrival at the MRS, for example, for $\geq 95 \%$ of the arriving fuel over the time frame of MRS operations.

A system based on "average" inventory-imposed characteristics, e.g., 33,000 MWd/MTU 10-year decay, will be limited to approximately the first 50\% of the inventory for reference PRDA fuel burnup assumptions. In that case, a second generation of casks would be required for the balance of the inventory. 
2.3. SENSITIVITY OF BURNUP AND AGE ON DESIGN BASIS

2.3.1. Overall Systems Capability as Impacted by Burnup Extensions

A significant spectrum of age and age/burnup combination will exist for the LWR fuel inventory as was discussed in Section 2.2 above. The age of fuel to be transferred to an MRS or the repository will typically vary from 30 years for fuel transferred in 1998 to as low as five years for fuel transferred in 2025. An earlier 1996 startup of the MRS will result in fuel being aged approximately two years less over most of the time horizon relative to the base case of 1998 startup.

Within the overall spectrum of the inventory age characteristics impacting the shlelding dose and heat load, the potential impact of a 1996 versus a 1998 facility startup is not significant. However, if the future PWR and BWR designs are based on extended burnup, the impact will be large and a significant increase in the dose and heat load design basis will be required if a high inventory handling capability is to be achieved.

As discussed in Appendix A, the equations for both the gamma shielding source term and the heat load source term assume that these terms are proportional to burnup for a given age of the fuel. This assumption is valid for these two terms but would not be valid for the neutron source term, which increases more dramatically with increased burnup and does not fall off rapidly with decay age. Thus, a significant increase in burnup would mostly impact the neutron shielding requirements, particularly for transport of the fuel from the reactors to the MRS or repository or, in the later years of operations at an integrated MRS, for transport of packaged fuel from the MRS to the repositories. 
Our PRDA evaluations have assessed the impact on the design basis and the time-phased inventory handling capability for two fuel burnup assumptions. These were ( 1 ) the reference PRDA burnup projections as supplied by PNL and (2) an extended burnup scenario to approximate EIA projected burnup. In the latter case 1 t was assumed that the 1985 burnup distribution from the reference PRDA case was increased by $3.3 \%$ per year for 11 years to 1996 for a cumulative increase of 43\%. From 1996 onward it was assumed that the $43 \%$ increased burnup remained in effect. Figure 2.3-1 illustrates the variation in burnup for several time phases for the two burnup scenarios assumed. Figure 2.3-2 shows a plot of the mean heat load into the repository (or MRS) for the reference burnup and for the extended burnup. The extended burnup results in a $43 \%$ increase in the mean heat load for fuel delivered after about 2012 .

A time-phased statistical analysis of the neutron dose (primarily applicable for transportation) and the heat load (primarily applicable for storage or disposal) was carried out for both the reference and the extended burnup projections. The resultant time-phased MTU distributions to these two terms were generated and used to estimate the inventory handling capability for systems having differing neutron shielding and heat load design bases. The two design bases were the customary DOE basis of 33,000 MWd/MTU 10 years and the proposed GA system basis of 40,000 MWd/MTU 7 years. The neutron dose term and the heat load terms for these design basis values are:

\begin{tabular}{llll} 
& $\begin{array}{c}\text { Current } \\
\text { DOE Basis }\end{array}$ & \multicolumn{1}{c}{$\begin{array}{l}\text { Proposal } \\
\text { GA Basis }\end{array}$} \\
Heat 1oad, KW/MTU & 1.10 & & 1.80 \\
Direct neutron, $\mathrm{N}_{\mathrm{O}}{ }^{1} / \mathrm{sec}^{-M T U}$ & $1.9 \times 10^{8}$ & $4.25 \times 10^{8}$ \\
Burnup/age & $33,000 / 10$ & $40,000 / 7$
\end{tabular}

Figures 2,1-7 and 2,1-8 showed plots of the total MTU fraction with less than a given direct neutron source or heat load, respectively. In 


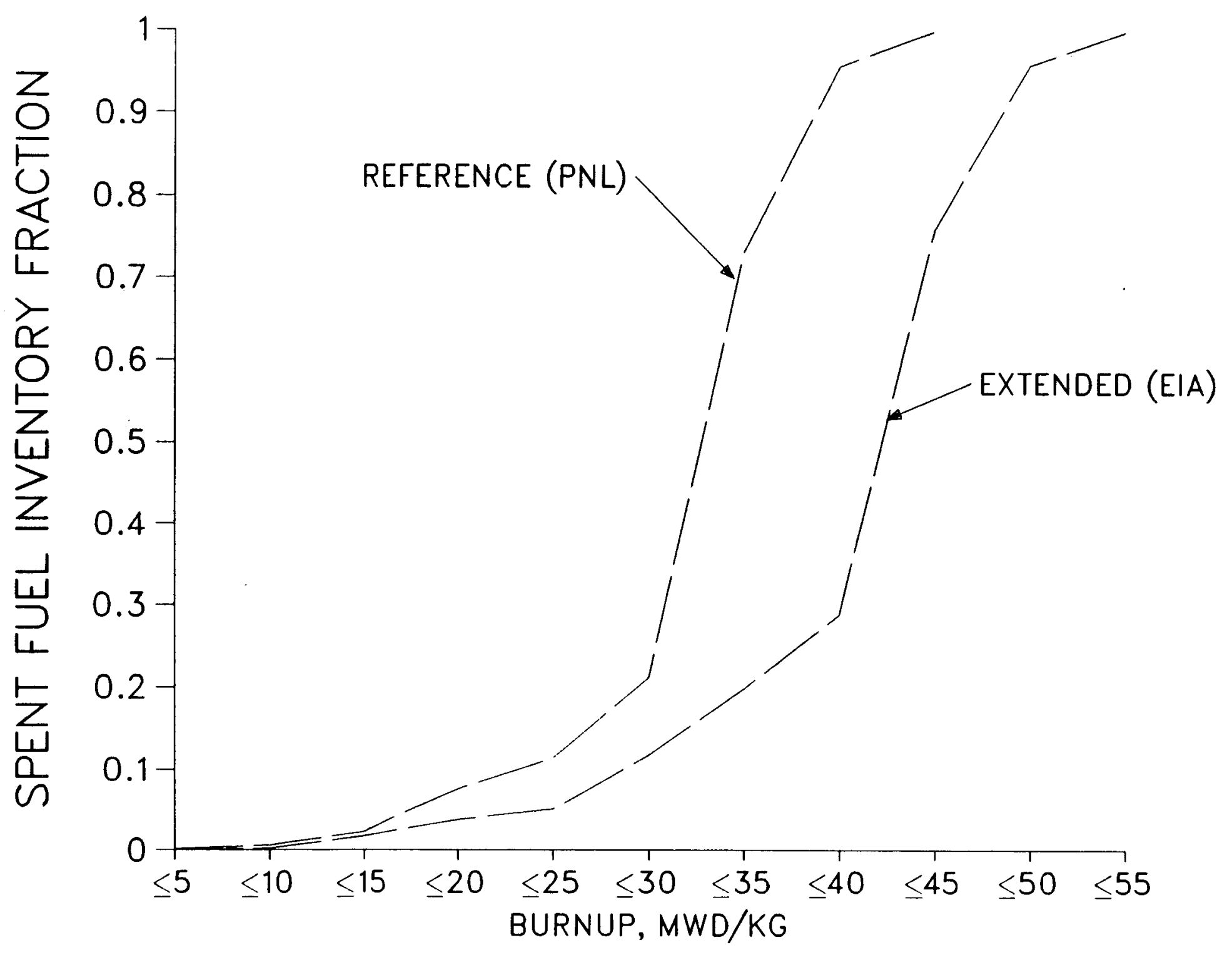

Fig. 2.3-1. PWR burnup uncertainties predicted for discharges through 2020 


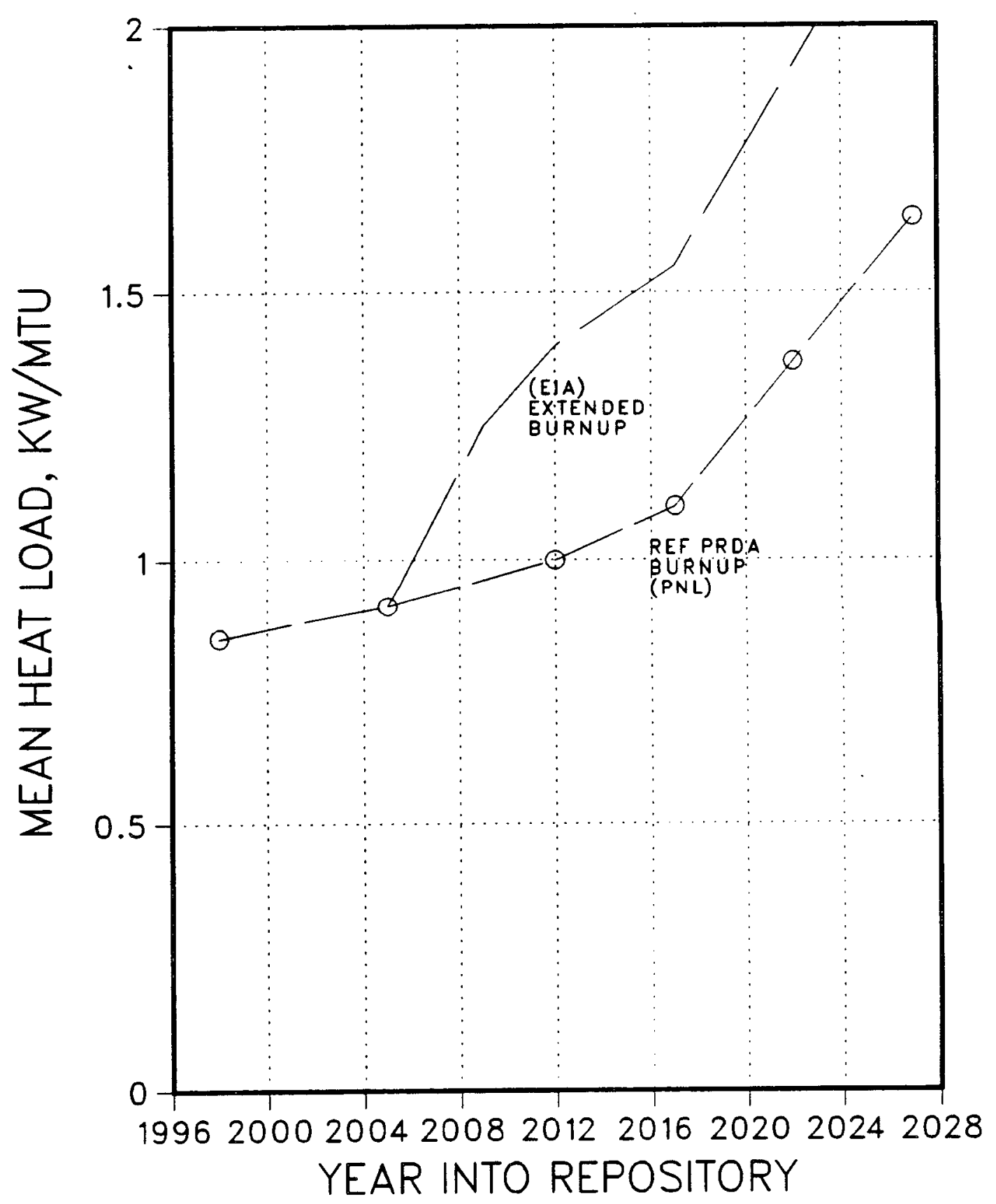

Fig. 2.3-2. Mean heat load versus year of emplacement 
each case the cumulative MTU distribution is for all fuel discharged up to the given year and for which the age into the repository or MRS would be equal to, or greater than, the indicated value on the legend. The values plotted in Figs. 2.1-7 and 2.1-8 were for the reference PRDA burnup assumptions. Similar results for heat load are shown in Fig. 2.3-3 for the extended burnup assumption as discussed above.

These results were used to determine the time variation of the inventory handling capability of a system based on either the DOE design basis or the proposed GA universal canister design basis.

An estimate of the actual inventory handling capability for an acceptance schedule based on a maximum age of about 28 years at the start of shipment to an MRS or repository with a 1998 startup clearly shows that an extended burnup assumption would severely impact a system based on the current DOE design basis. With extended burnup, such a reference system would have a capability of only about $57 \%$ for discharges through 1995, and the capability would continue to drop to an overall inventory capability of on 1 y $20 \%$ to $25 \%$ for the cumulative inventory discharges through 2020. For reference burnup conditions, the current reference system would have an $80 \%$ capability for discharges through 1995 with the overall capability being reduced to about $50 \%$ for a11 fuel discharged through 2020.

The proposed GA universal canister design basis would have nearly a $100 \%$ handling capability for reference burnup. The overall capability would remain at $\sim 100 \%$ for discharges through 1995 for extended burnup while the overall capability would be reduced to $\sim 75 \%$ for all discharges through 2020.

\subsubsection{Impact on Integrated MRS Design Basis}

The current acceptance schedule and shipments into and out of an integrated MRS leads to a maximum storage requirement of only 


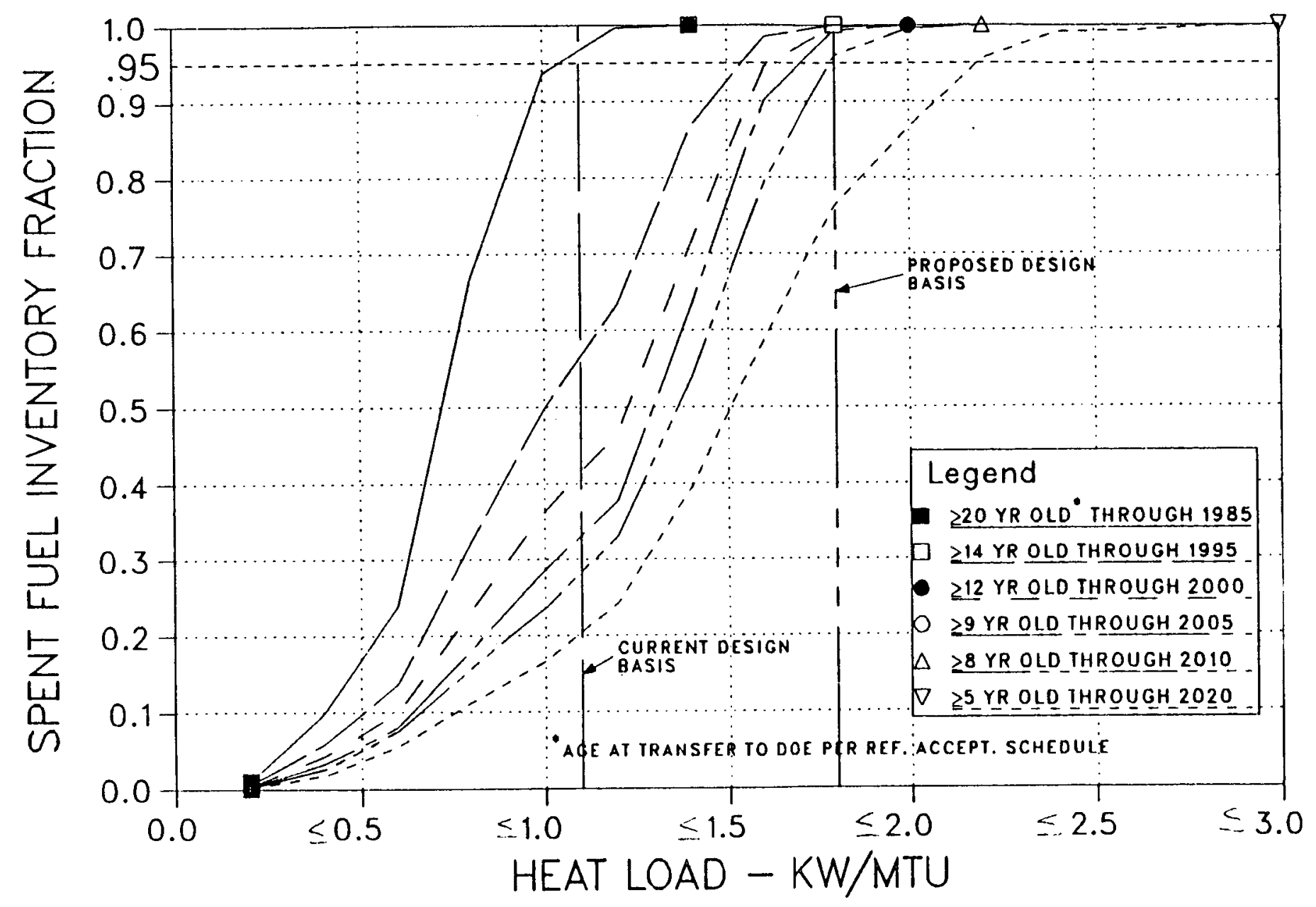

Fig. 2.3-3. Heat load distribution for extended fuel burnup 
$\sim 21,300 \mathrm{MTU}$, which is only $17 \%$ of the total inventory. In the later years of operation, incoming fuel will be typically five to seven years of age and the short holdup time in the integrated MRS will result in fuel having about seven to 10 years or less of aging being shipped from the MRS to the two repositories.

The current plans for the integrated MRS call for fuel consolidation at the MRS prior to shipment to the repository. The relatively high heat loads and shielding dose terms, particularly neutron dose, for such consolidated fuel loadings could exceed current cask design limits, requiring a reduction in payload. This would be particularly true if extended burnup does occur. The universal canister/cask system concept, which would be designed for much higher consolidated rod payload transfers out of the MRS, would be particularly attractive in the later years of operation of the waste program, particularly if an MRS is an integral part of that program.

The annual discharge burnup distribution in the year 2010 for both the reference and the EIA extended burnup assumption is typical of the annual discharge burnup distributions to be expected for discharges over the last 15 or so years of the MRS or repository operating history. Figures 2.3-4 and 2.3-5 show plots of the neutron dose source term and heat load for these two typical annual burnup distributions, with 5 , 7.5 , and 10 years aging assumed as bracketing the typical age range of fuel coming into or leaving the integrated MRS. As can be noted, the mean neutron source term increases dramatically if higher burnup occurs. In both figures, the DOE nominal and the proposed GA universal canister design basis values are indicated, and a dashed curve indicates the inventory capability of each system for the indicated fuel age.

It is assumed that the indicated design basis for a given dose or heat load per MTU includes a shielding or heat load capability for consolidated rods at the given design value for the annual shipments from the MRS. 


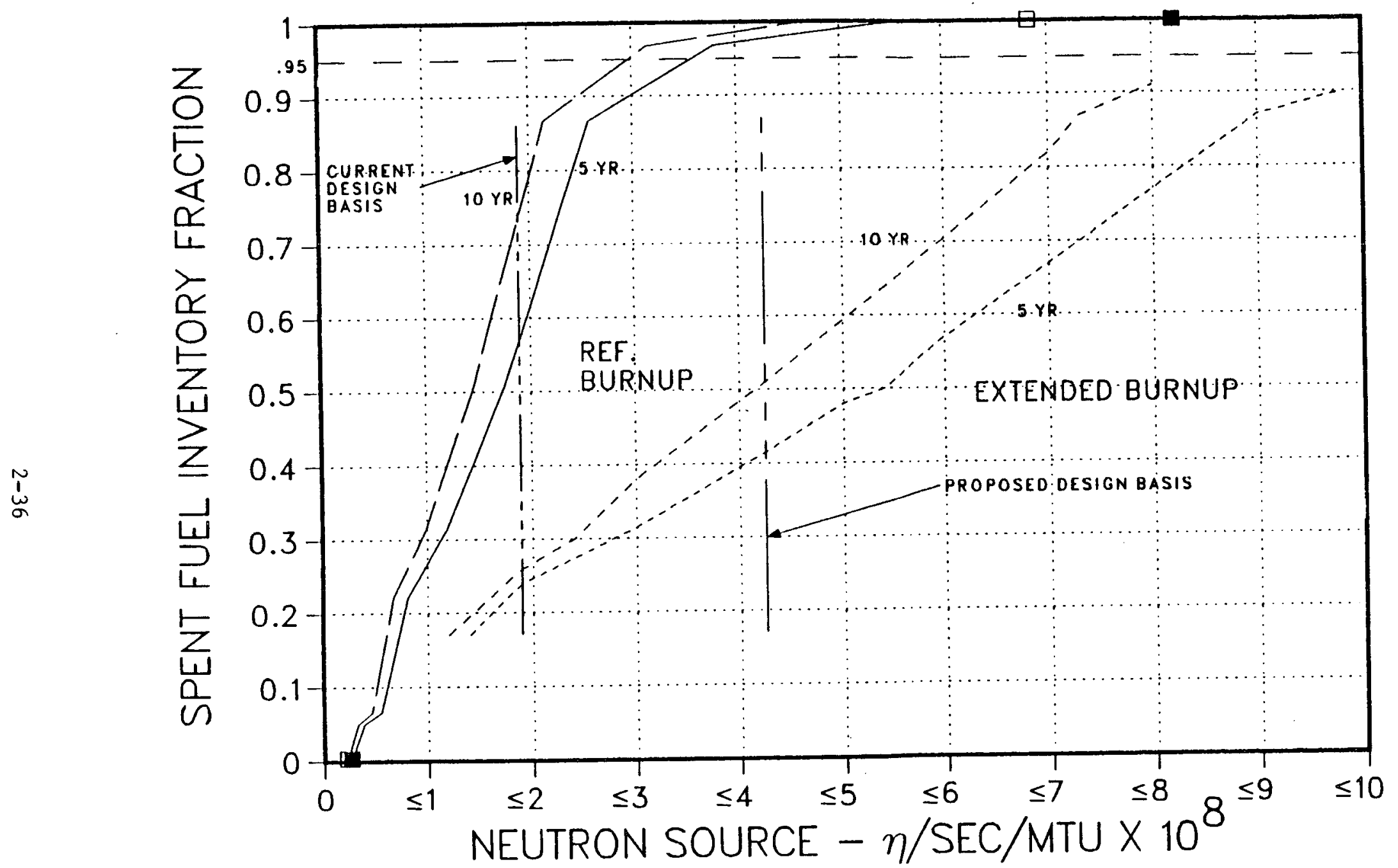

Fig. 2.3-4. Neutron source for fuel discharged in 2010 


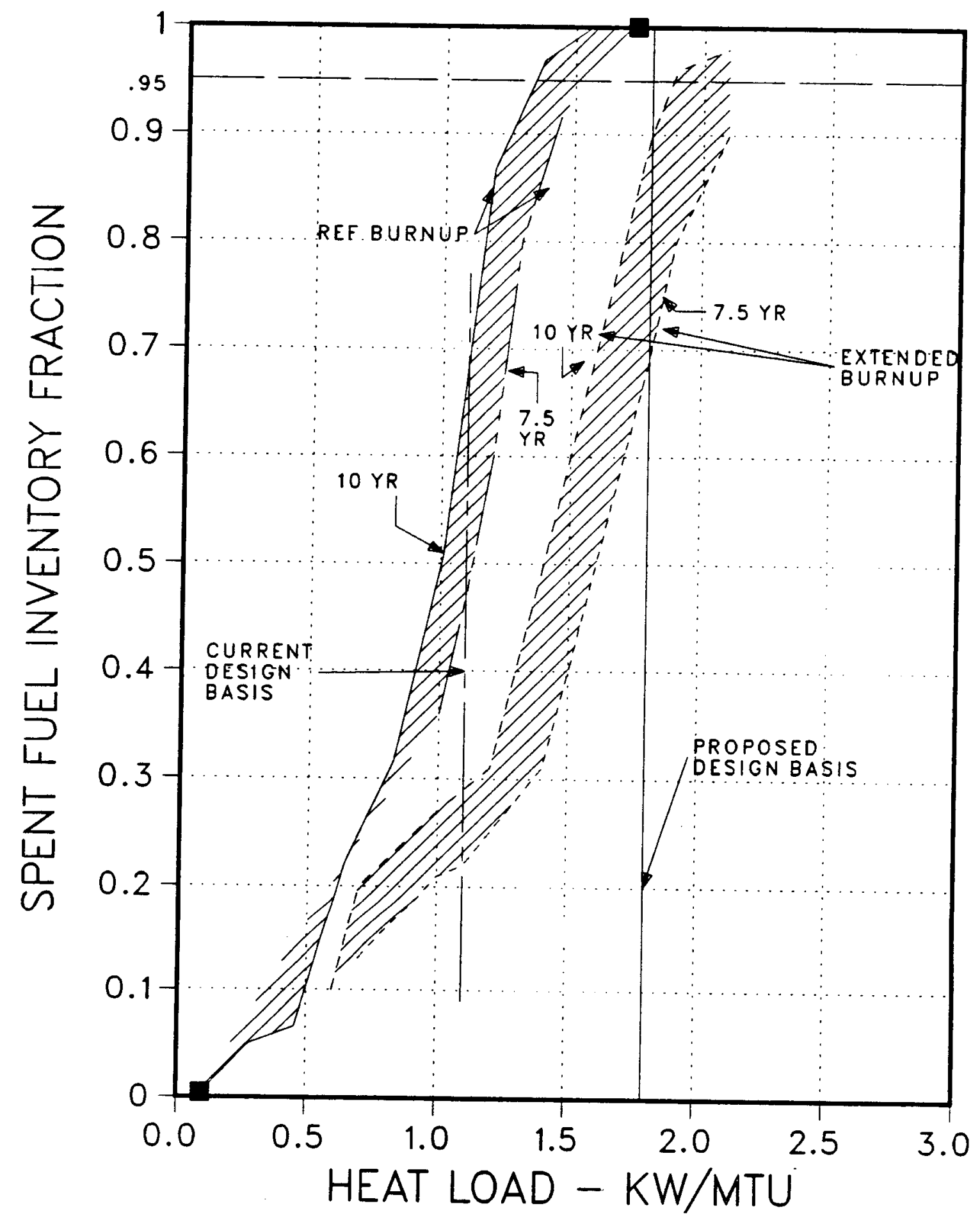

Fig. 2.3-5. Heat load for fuel discharged in 2010; reference versus extended burnup 
Table 2.3-1 summarizes the nominal design cask payload capability for both systems for fuel transfers with reference burnup to the repository. The DOE nominal values are for fuel packaged for burial to each repository media while the universal canister design assumes that the consolidated rods from the MRS will be packaged for burial at the repository. The DOE reference cask and payload data were derived from tabular data given in Ref. 1-1. As may be noted, the overall cask payload of the proposed universal canister system, when fully loaded, yields that same payload as the reference system for the salt repository, $29 \%$ more for basalt and double the reference value for the tuff/granite repository.

Table 2.3-2 lists pertinent data including total cask heat loads and neutron source strengths for nominal loadings for the two cask design basis points. The highest values of cask heat load and neutron source strength, based on the reference waste package rail cask with loadings for a salt repository, are shown in comparison to the proposed GA rail cask design parameters.. The proposed heat load values are $\sim 50 \%$ higher and the proposed neutron source strengths more than double the reference values.

The table also summarizes the expected inventory handling capability of the two different casks for the expected annual transfers from the integrated MRS to the repositories in the later years of the MRS operations. The range of values corresponds to a range in age of 7.5 to 10.0 years cooling as was fllustrated in Figs. 2.3-4 and 2.3-5.

As shown, the reference system would be highly constrained particularly if extended burnup becomes a reality. The proposed universal canister system would be much less constrained and, as discussed in Section 7.1.1, would meet this constraint by having the capability to transport hot assemblies directly from the reactor sites to the repository with the potential capability for direct burial of the canistered assemblies, i.e., such limited shipments would bypass the MRS entirely. 
TABLE $2 \cdot 3-1$

RAIL CASK NOMINAL PAYLOAD CAPABILITY COMPARISON

\begin{tabular}{|c|c|c|c|c|}
\hline & DOE & Waste & Package Cask & $\begin{array}{c}\text { Universal Canister } \\
\text { Cask }\end{array}$ \\
\hline & Sa1t & Basalt & Tuff/Granite & Al1 Repositories \\
\hline Overpack & Yes & Yes & Yes & No \\
\hline Total cask weight, tons & 145 & 143 & 141 & 114 tons \\
\hline $\begin{array}{l}\text { Consolidated PWR, } \\
\text { equivalent assemblies }\end{array}$ & 36 & 28 & 18 & 36 \\
\hline
\end{tabular}


TABLE 2.3-2

TRANSPORT CASK FUEL HANDLING CAPABILITY COMPARISON FOR TYPICAL ANNUAL TRANSFERS FROM MRS TO REPOSITORY AFTER ABOUT 2015

\begin{tabular}{|c|c|c|c|}
\hline Cask Design & Current DOE & Basis & Proposed System Basis \\
\hline & \multicolumn{2}{|l|}{ 145-ton rall } & 114-ton rail \\
\hline Fuel form & \multicolumn{2}{|c|}{$\begin{array}{l}\text { Consolidated; with } \\
\text { overpack }\end{array}$} & $\begin{array}{l}\text { Consolidated; without } \\
\text { overpack }\end{array}$ \\
\hline Design basis & \multicolumn{2}{|c|}{$33,000 \mathrm{MWd} / \mathrm{MTU} ; 10 \mathrm{yr}$} & $40,000 \mathrm{MWd} / \mathrm{MTU} ; 7 \mathrm{yr}$ \\
\hline Cask heat load, kW & \multicolumn{2}{|l|}{$19.8(\mathrm{sal} t)$} & 29.9 \\
\hline Cask neutron source & \multicolumn{2}{|c|}{$3.4 \times 10^{9}(\mathrm{sa} 1 \mathrm{t})$} & $7.1 \times 10^{9}$ \\
\hline $\begin{array}{l}\text { Gamma shielding thick- } \\
\text { ness, eff. in. steel }\end{array}$ & \multicolumn{2}{|l|}{6.46} & 11.1 \\
\hline $\begin{array}{l}\text { Neutron shield thick- } \\
\text { ness, eff. in. }\end{array}$ & \multicolumn{2}{|l|}{3.7} & 6.2 \\
\hline $\begin{array}{l}\text { Burnup basis } \\
\% \text { inventory capability }\end{array}$ & \multirow[t]{2}{*}{ Ref. PDRA } & Extended & Ref. PDRA \\
\hline Range (from Fig. 2.3-8) & & & \\
\hline 7.5 yr age & $\sim 47 \%$ & $\sim 26 \%$ & $\sim 67 \%$ \\
\hline 10.0 yr age & $\sim 73 \%$ & $\sim 28 \%$ & $\sim 100 \%$ \\
\hline
\end{tabular}


No attempt has been made to estimate the possible derating of payload that would be required to allow the reference system to transfer the hotter fuel to the repository during this time. With a total weight of 289,870 1b (for salt repository) there is little margin for significant increases in both the neutron and gamma shielding weights that would be required for handling the hotter fuel. An approximate estimate for just increasing the neutron shielding is that a 12,000 to $14,0001 \mathrm{~b}$ increase in total weight would be required, which would put the total cash weight at or over the 150-ton limit.

Additional detailed inventory analysis, which was beyond the scope of these PRDA evaluations, should be performed to define optimum strategies for assuring that the integrated MRS and the repositories can be fully integrated to maintain maximum flows to the repositories in a cost-effective manner. These preliminary results would indicate that there will be potential problems with the integrated MRS system in the later years of operation unless a much higher system design basis is incorporated into the essential system component design. It also appears that additional aging at the MRS and/or the transfer of the packaging for disposal function to the repository in the later years would be required if cost-effective shipments within the 150-ton limit are to be realized.

\subsection{SUGGESTED APPROACHES TO WASTE ACCEPTANCE}

The current reference waste acceptance strategy is based on the acceptance of "oldest fuel first." This strategy results in a significant increase in the heat load and shlelding requirements over time for fuel being shipped to, or handled at, the MRS or the repository. The oldest fuel to arrive at the MRS or repository is typically 25 or more years decayed at the start of operation of efther facility. In the later years of operation the fuel, much of it at higher burnup, will be only five to seven years decayed at arrival. 
This acceptance strategy results in a continuously increasing source-term and heat-load distribution over the years of facility operation, i.e., the mean heat load into the MRS or repository will typically vary by a factor of two or more over the facility lifetime.

The analysis of the inventory characteristics has shown that both the heat load and the gamma shielding source term are nearly proportional to burnup for a given decay age. This linearity assumption, coupled with simplistic, but sufficiently accurate, decay terms for the aging effect, leads to the conclusion that nearly constant gamma source terms and heat loads result for combinations of burnup and age for which the burnup/age ratio is approximately constant.

This nearly linear relationship is illustrated in Fig. 2.4-1 for the gamma shielding source term. A similar result would be obtained for the heat load equivalencing. For the proposed reference universal canister system a recommended gamma dose source term of $4.5 \times 10^{15} \mathrm{MeV} / \mathrm{sec} /$ MTU was specified for obtaining a $>95 \%$ inventory handling capability (at a $2: 1$ consolidation loading).

As illustrated in Fig. 2.4-1, this source term would result for any fuel for which the ratio of burnup (MWd $/ \mathrm{kg}$ ) to age (years) equals $\sim 6.0$. For example, four year fuel of $24 \mathrm{MWd} / \mathrm{kg}$ burnup would yield the same dose source term (or heat load) as $40 \mathrm{MWd} / \mathrm{kg}$ burnup and 6.8-year cooling or $36 \mathrm{MWd} / \mathrm{kg}$ fuel and 6 -year cooling, etc.

A system based on the current reference design basis, i.e., $33 \mathrm{MWd} / \mathrm{kg}$ and 10-year aging, would have a shielding design based on a gamma dose source term of $2.6 \times 10^{15} \mathrm{MeV} / \mathrm{sec} / \mathrm{MTU}$ as also shown in Fig. 2.4-1. Such a system, if designed to handle only intact assemblies at the indicated source, is much more inventory-limited than a system based on the proposed reference design criteria. From the data point on the curve for the $33 \mathrm{MWd} / \mathrm{kg} 10-\mathrm{yr}$ source term of $2.6 \times 10^{15} \mathrm{MeV} / \mathrm{sec} / \mathrm{MTU}$, it can be deduced that this specification, for which the burnup/age 


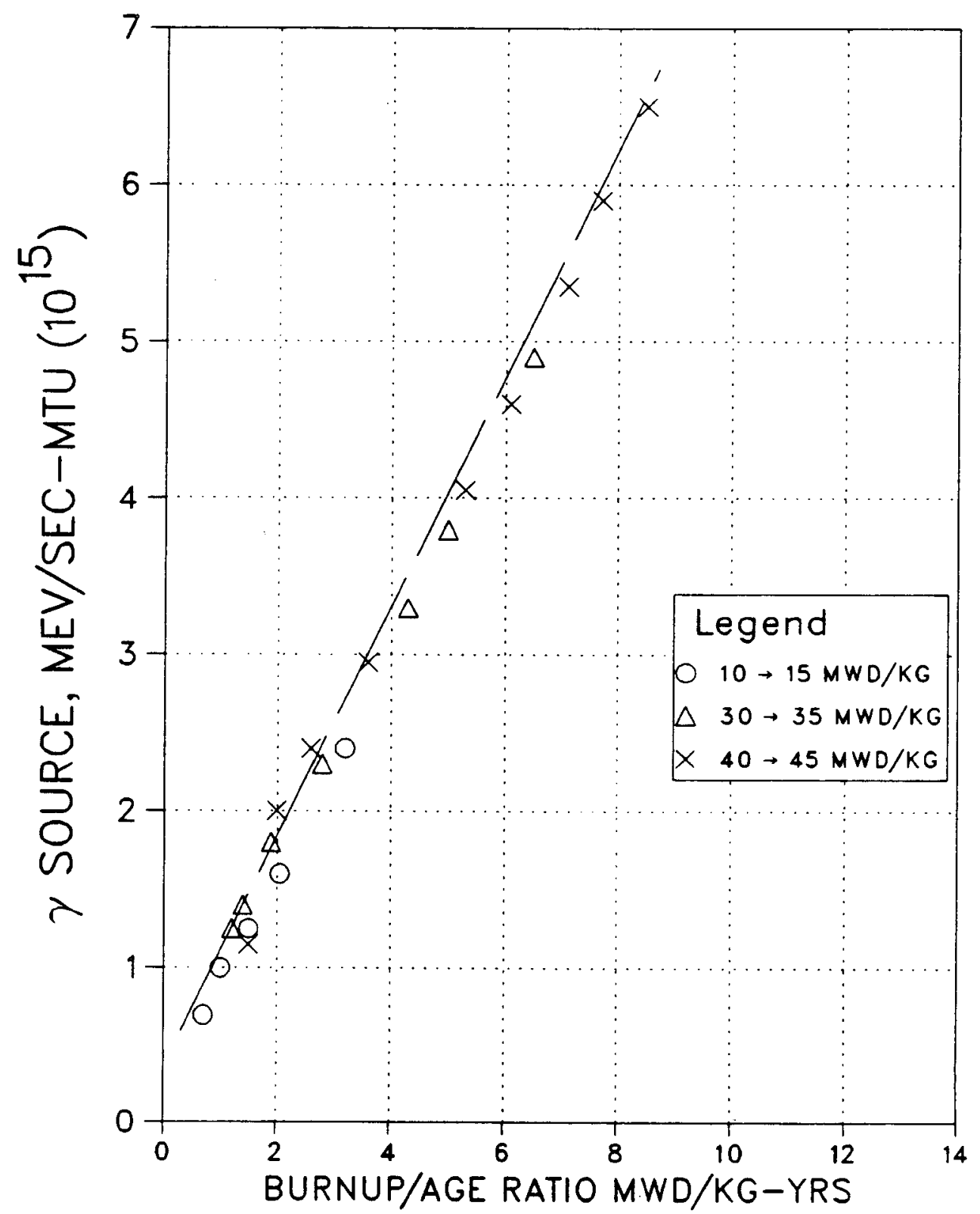

Fig. 2.4-1. Gamma source versus burnup/age ratio 
ratio is $3: 3$, would also handle $16.5 \mathrm{MWd} / \mathrm{kg}$ burnup fuel at 5 years aging or $26 \mathrm{MWd} / \mathrm{kg}$ fuel at 7.9 years aging, for example. Higher burnup fuel, such as $45 \mathrm{MWd} / \mathrm{kg}$ burnup fuel, would require 13.6 years aging, for example.

An acceptance strategy based on equivalencing of burnup and aging could be developed to more nearly levelize the shielding dose source terms (transportation) or the heat load (storage or disposal) source terms for fuel going to or requiring handling at the MRS or respository. The development of such an acceptance strategy was not part of our PRDA work scope but could be developed as part of follow-on studies, particularly now that the inventory analysis methods are in place.

A simplistic acceptance strategy could, for example, be based on an equivalencing for accepting fuel in a given year for which the source terms are nearly constant, i.e., for fuel with a constant burnup/age ratio. Such a scheme would involve accepting fuel of low burnup/low age with fuel of higher burnup/higher age for example.

This simplistic equivalencing strategy could be expanded to allow a leveling of the repository heat loads for example by the mixing "old" and "new" fuels or consolfdated and intact fuel, as allowed by the universal canister size and shape, of appropriate burnup at the MRS packaging facility to yield a desired average heat load per package. A particularly useful investigation would be to determine the minimum number of discrete waste package sizes for each repository type that would be required to handle the total inventory going into the repository. 


\section{CRWM SYSTEM DEFINITION AND REQUIREMENTS}

This section defines both the reference CRWM system and the system with an integrated MRS as modified by the proposed GA universal canister. Storage and throughput requirements are based on the reference acceptance schedule given in Table 2.1-1 of Section 2 .

\subsection{SYSTEM DEFINITION}

Figures 3.1-1 and 3.1-2 define the two systems which have been used in this study. Both systems are essentially the same as those described in the PRDA assumptions given in Ref. 1-1. The major difference in the GA systems is the introduction of a universal canister at the reactor prior to any handling of the spent fuel in the reactor storage pool. This canister when filled with intact or consolidated fuel becomes the handling and storage unit to be used throughout the system. The universal canister is discussed further in section 5.

In the reference system shown in Fig. 3.1-1, the canister is loaded in the reactor pool and is elther stored in an at-reactor dry storage cask or placed in a shlpping cask for delfvery to the repositories. At the repositories, the universal canister will be processed as required by the specific geologic media. Most of the canisters will contain intact fuel assemblies which will be removed, consolidated, and repackaged into the media-specific waste package. Consolidated fuel canisters will either be repackaged or loaded directly into overpacks for disposal.

In the system with an integrated MRS shown in Fig. 3.1-2, the universal canister is still loaded in the reactor pool and stored at-reactor if required. All canisters are then shipped to the 


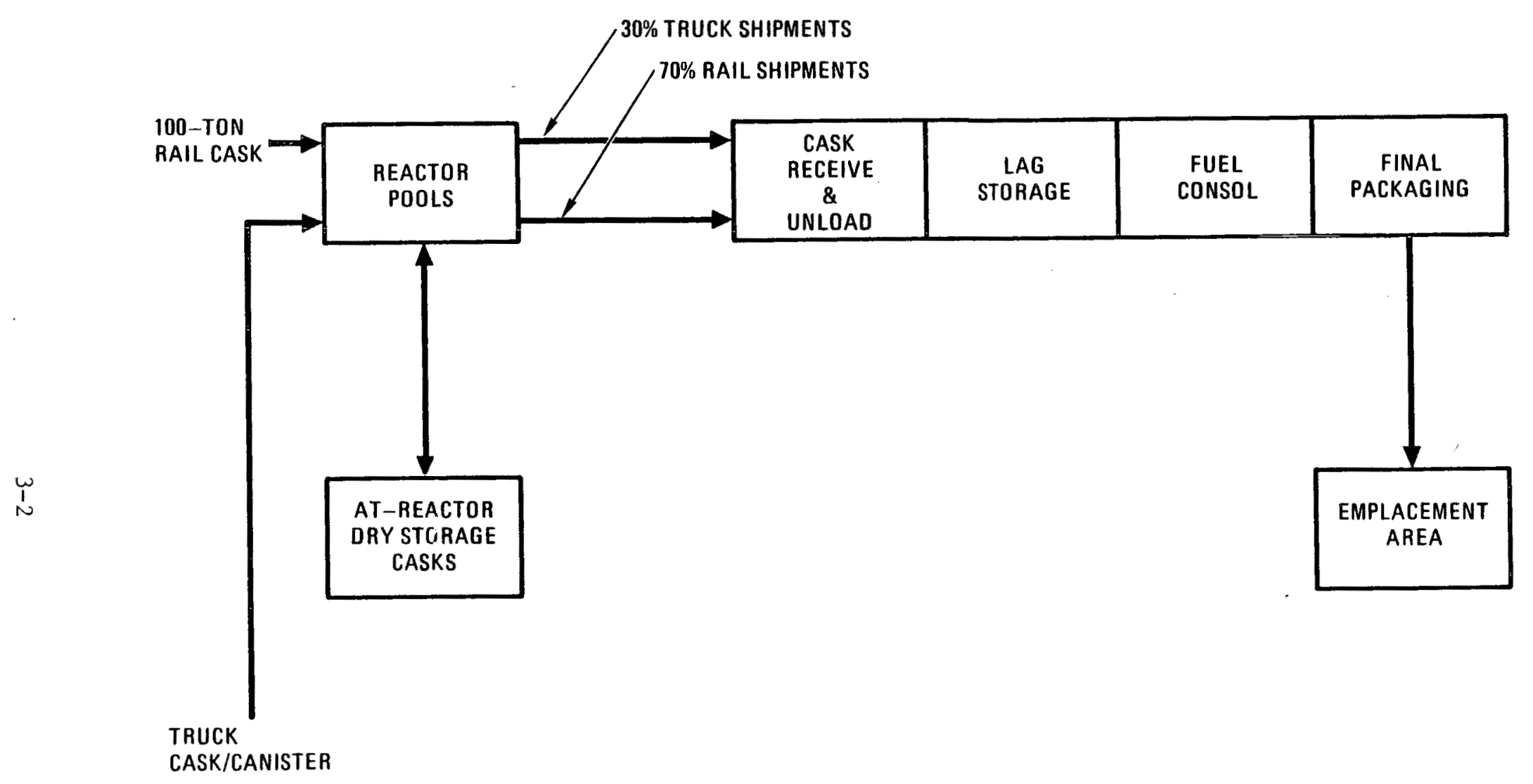

Fig. 3.1-1. Reference CRWM system 


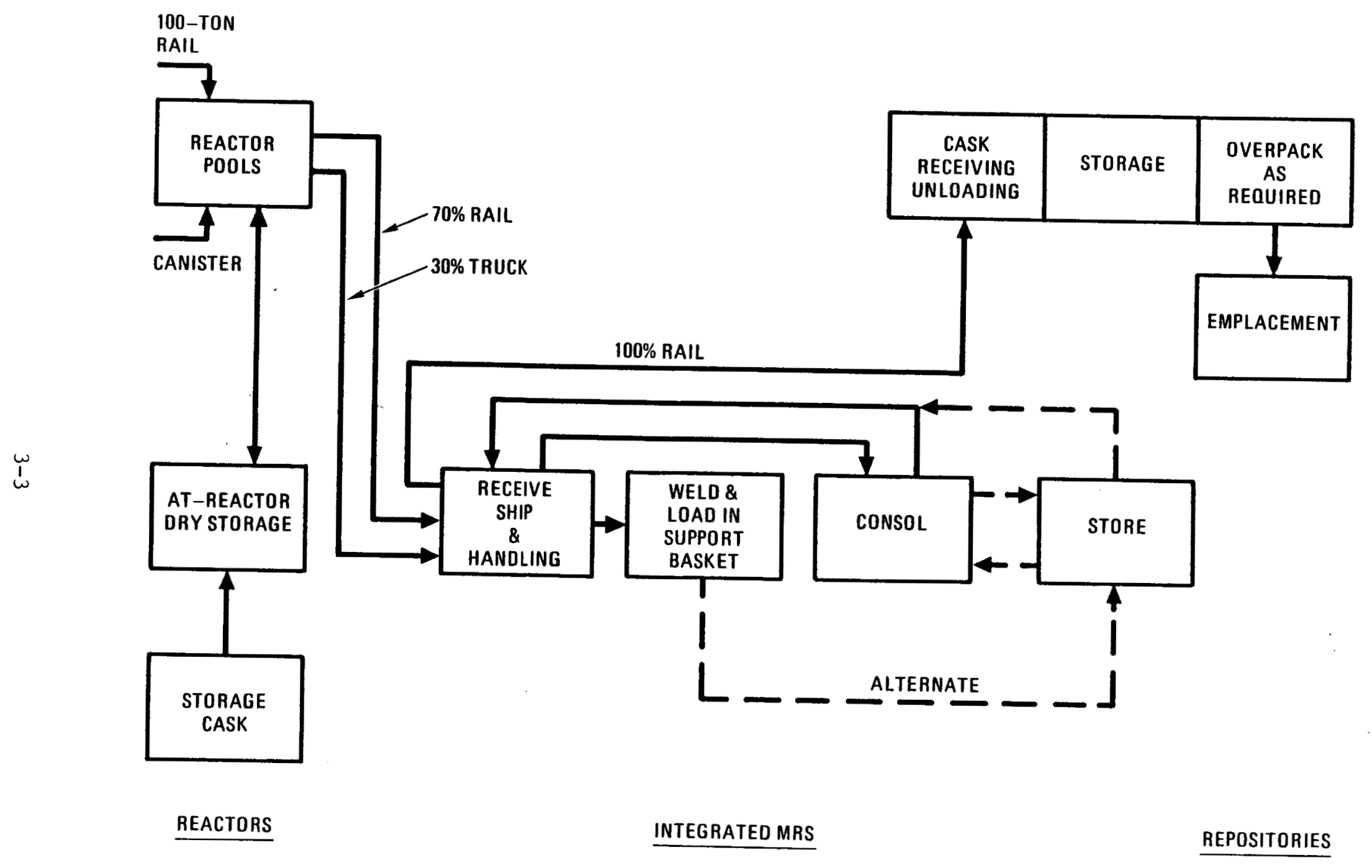

Fig. 3.1-2. Integrated MRS system 
integrated MRS, where several options are avallable for their processing. They can be stored for several weeks in a lag storage facility or for several years in the MRS concrete storage casks. The fuel assemblies can be consolidated efther before, during, or after storage, since both the intact and consolidated fuel utilize the same universal canister. At the repositories, the universal canisters are placed in overpacks for disposal as required by the specific geologic media.

\subsection{WASTE RECEIVING AND SHIPPING RATES}

For the reference case, spent fuel flows from reactors straight to repositories as was shown in Fig. 3.1-1, and the shipping and receiving rates are shown in Table 2.1-1 in Section 2. Additionally, spent fuel is transferred in and out of at-reactor dry storage. The inventory of spent fuel in dry storage depends on avallable pool storage and the acceptance schedule (Table 2.1-1). Table 3.2-1 shows the inventory of dry storage for the reference case as provided by Ref. 3-1.

The shipping and receiving rates for the integrated MRS System are shown in Table 2.1-2 in Section 2, and the at-reactor dry storage (DRS) inventory is given on Table 3.2-2 as provided by Ref. 3-2.

\subsection{WASTE STORAGE REQUIREMENTS}

The DRS requirements can be seen on Tables $3.2-1$ and $3.2-2$ as the maximum inventory points. For the reference system, this occurs in the year 2002 at $7312 \mathrm{MTU}$, while the integrated MRS system reduces this requirement to 2887 MTU in the year 1995.

The MRS storage requirement for the integrated MRS system and on-time repositories is 21,300 MTU in the year 2005 as seen in Table 2.1-2. 
TABLE 3.2-1

AT-REACTOR DRY STORAGE INVENTORY

FOR REFERENCE CASE (MTU)

\begin{tabular}{lc} 
Year & DRS Inventory \\
\hline 1980 & \\
1981 & \\
1982 & \\
1983 & \\
1984 & \\
1985 & \\
1986 & \\
1987 & 20 \\
1988 & 60 \\
1989 & 180 \\
1990 & 339 \\
1991 & 564 \\
1992 & 969 \\
1993 & 1311 \\
1994 & 1777 \\
1995 & 2368 \\
1996 & 2887 \\
1997 & 3697 \\
1998 & 4581 \\
1999 & 5033 \\
2000 & 5930 \\
2001 & 6870 \\
2002 & 7261 \\
2003 & 7312 \\
2004 & 5853 \\
2005 & 4680 \\
2006 & 3480 \\
& \\
1509 \\
1989
\end{tabular}


TABLE $3 \cdot 2-2$

AT-REACTOR DRY STORAGE INVENTORY

FOR THE INTEGRATED MRS SYSTEM (MTU)

$\begin{array}{cc}\text { Year } & \text { DRS Inventory } \\ 1986 & 20 \\ 1987 & 60 \\ 1988 & 180 \\ 1989 & 339 \\ 1990 & 564 \\ 1991 & 969 \\ 1992 & 1311 \\ 1993 & 1777 \\ 1994 & 2368 \\ 1995 & 2887 \\ 1996 & 1897\end{array}$




\subsection{REFERENCES}

3-1. "WADCOM-MF Runs for PRDA Reference Cases," Weston Consultants Draft, March 1985.

3-2. WADCOM-MC runs for GA Integrated MRS Case, Weston Cycle Nos. 43 through 47. 


\section{SYSTEM FUNCTIONAL REQUIREMENTS AND DESIGN CRITERIA}

This section presents a summary of the functional requirements and design criteria that were used in defining the GA universal canister concept for a radioactive waste packaging and handling system. Many of the items listed in this section were taken directly from the PRDA assumptions document ( $\operatorname{Ref}, 1-1$ ). Discussion is provided for the major items which do not originate in that document. A complete list of the functional requirements and design criteria used in this study is contained in Appendix B.

\subsection{FUNCTIONAL REQUIREMENTS OF THE UNIVERSAL CANISTER}

\subsubsection{General Requirements}

1. Provide the capability of handling at least $95 \%$ of the total expected spent fuel inventory either as intact assemblies or as consolidated fuel rods.

2. Minimize operations which handle bare spent fuel assemblies (i.e., provide the cleanest possible handling system) and provide standardized handling interfaces.

3. Provide the flexibility to enable the system to operate if changes are made to the current mission plan or expected spent fuel inventory. Examples of changes which could occur include changes in the spent fuel inventory ages or burnups, changes in the functions of a system MRS facility, or changes in the disposal package designs. 
4. Provide criticality control, the ability for containment, and limited physical protection of the spent fuel.

5. Operate efficiently with truck and rail shipping casks, storage casks, or storage modules.

6. Operate with minimum impact on equipment and operations at the reactor storage pools.

\subsubsection{Specific Requirements}

1. Containers must be provided for the transport, storage, or ultimate disposal of SFAs or consolidated fuel rods.

2. Canisters must have the capability of efficient interchangeability between transportation, storage, and disposal missions.

3. Canisters must have mechanical closures adequate to meet containment of transport and short-term storage. These closures must have the ability to be welded for long-term applications.

4. Canisters must have a lifting capability to allow them to be transferred between transportation, storage, and disposal system components.

5. Canisters must have an internal support system for the SFAs or consolidated fuel rods that promotes heat transfer from the canister and aids in maintenance of a subcritical condition of the spent fuel. 
6. If a single universal canister is defined, it must have the capability of operating efficiently in the following modes:

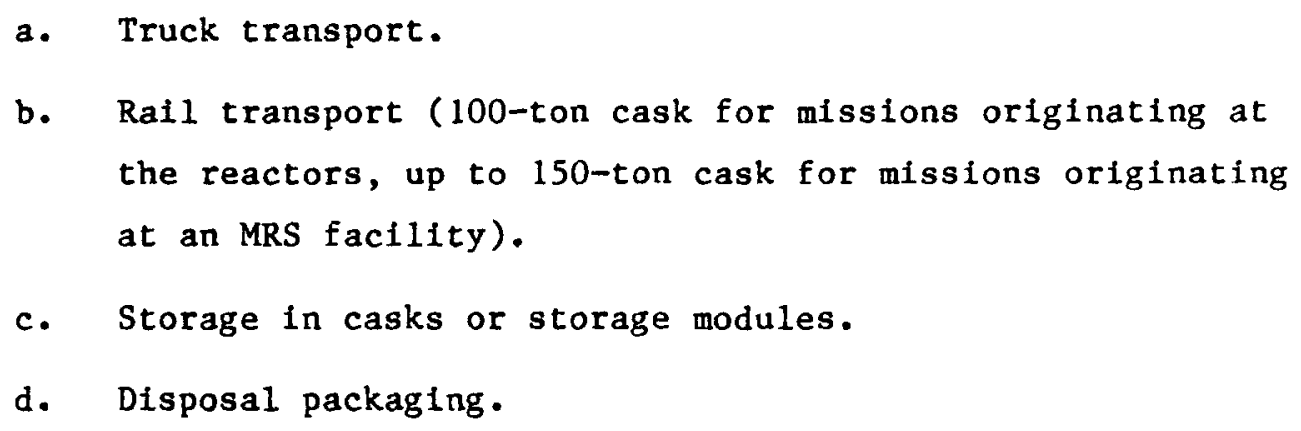

7. Maximum shipping rate of the system is $6000 \mathrm{MTU} / \mathrm{year}$.

8. The spent fuel inventory specified for the PRDA program totals 124,600 MTU. Divided into PWR and BWR spent fuel assemblies at a ratio of about $33 \% / 67 \%$ by weight of contained uranium, the inventory totals 177,700 PWR SFAs and 261,000 BWR SFAs.

9. Thirty percent of the spent fuel shipped from reactors will be by truck mode. The remaining $70 \%$ will be by rail cask at a 100-ton limit for the loaded cask. One-hundred percent of the shipments from an MRS facility will be by rail cask at a loaded cask weight of up to 150 tons.

\subsection{DESIGN CRITERIA FOR THE UNIVERSAI CANISTER}

\subsubsection{Spent Fuel Inventory}

\section{Nuclear Characteristics}

A system was devised to convert the age and burnup of the spent fuel into equivalent heat loss, radiation sources, and initial fissile enrichment values. Once the spent fuel was grouped by these energy levels, a cutoff level was established 
which encompasses more than $95 \%$ of the total spent fuel inventory defined for the PRDA program. This cutoff level occurs at the energy limits listed in Table 4.2-1. For comparison, the generally used "nominal criteria" are listed alongside the GA selected criteria in Table 4.2-1. Note that the GA-selected criteria encompass more than $95 \%$ of the PRDA spent fuel inventory, while the nominal criteria encompass less than $50 \%$ of that same inventory.

When the GA design criteria are converted to equivalent ages and burnup of spent fuel, the following combinations result:

$\begin{array}{ccc}\begin{array}{l}\text { Minimum Decay Time } \\ \text { Since Irradiation }\end{array} & \frac{\begin{array}{l}\text { Corresponding } \\ \text { Maximum Burnup }\end{array}}{5 \mathrm{yr}} & 30,000 \mathrm{MWd} / \mathrm{MTU} \\ 7 \mathrm{yr} & 40,000 \mathrm{MWd} / \mathrm{MTU} \\ 10 \mathrm{yr} & 55,000 \mathrm{MWd} / \mathrm{MTU}\end{array}$

The handling system defined views the preceding combinations of age and burnup as equivalent. A system designed to handle the shielding requirement, and the criticality requirement for any of the age/burnup combinations listed above can automatically also handle those requirements posed by the other combinations listed. The result is a system capable of handing almost any combination of spent fuel age and burnup likely to be encountered, with no derating necessary from its maximum design capacity.

In contrast to the age/burnup combinations which are encompassed by the GA design criteria, the nominal criteria are equivalent to an age/burnup value of 10 years and 33,000 MWd/ MTU. A system designed for the nominal age/burnup values is capable of handling less than $50 \%$ of the PRDA inventory before derating of the design capacity is required. 
TABLE $4.2-1$

COMPARISON OF SPENT FUEL NUCLEAR CHARACTERISTICS: GA DESIGN CRITERIA VERSUS NOMINAL CRITERIA

\begin{tabular}{lll}
\hline & \multicolumn{1}{c}{ GA Design Criteria } & \multicolumn{1}{c}{ Nominal Criteria } \\
\hline Heat load & $1.8 \mathrm{~kW} / \mathrm{MTU}$ & $1.1 \mathrm{~kW} / \mathrm{MTU}$ \\
Direct gamma source & $4.5 \times 10^{15} \mathrm{MeV} / \mathrm{sec} / \mathrm{MTU}$ & $2.6 \times 10^{15} \mathrm{MeV} / \mathrm{sec} / \mathrm{MTU}$ \\
Direct neutron source & $4.25 \times 10^{8} \mathrm{~N} / \mathrm{sec} / \mathrm{MTU}$ & $1.92 \times 10^{8} \mathrm{~N} / \mathrm{sec} / \mathrm{MTU}$ \\
Initial enrichment & $3.7 \% \mathrm{U}-235$ & $3.2 \% \mathrm{U}-235$ \\
\hline
\end{tabular}

Note: GA design criteria encompass more than $95 \%$ of the PRDA program spent fuel inventory. The nominal criteria encompass less than $50 \%$ of that same inventory. 


\section{Physical Characteristics}

To meet the requirement to handle at least $95 \%$ of the PRDA spent fuel inventory, the handling system must be capable of accommodating PWR and BWR SFAs of diverse cross sections and lengths. A detailed summary of the sizes and weights of SFAs and consolidated fuel rods which can be handled by the GA universal canister system is listed in Section 2.2 of Appendix B. The range of sizes and welghts contained in this 1isting encompasses more than $95 \%$ of the total expected inventory so that the total amount of spent fuel which falls outside of the GA criteria for nuclear and physical characteristics is limited to less than $5 \%$ of the total inventory.

\subsubsection{Nuclear Criticality Safety}

The GA universal canister/cask concept will be designed to ensure that spent fuel will be maintained in such a condition that the effective multiplication factor $\left(k_{\text {eff }}\right)$ is always less than 0.95 under either wet or dry conditions. For conservatism, a $0.03 \Delta \mathrm{k}$ uncertainty is assumed for criticality calculations. This results in the calculated

$k_{\text {eff }}$ for the system being limited to a maximum of 0.92 .

The GA design criteria for criticality analysis assume the fuel is fresh (unirradiated) at an enrichment level of $3.7 \% \mathrm{U}-235$.

\subsubsection{Radiological Protection}

The GA universal canister will be designed to operate with transportation casks capable of meeting all radiation limits specified in U.S. Department of Transportation Regulation 49CFR173. The system will be capable of operating at full design capacity assuming the spent fuel being transported is consolidated fuel rods having the equivalent 
age/burnup combination of 7 years out-of-reactor/40,000 MWd/MTU (or 5 years/30,000 MWd/MTU, etc. - see discussion in Section 4.2.1.).

During storage, the GA system will operate with storage casks or storage modules capable of meeting the radiation limits specified in American Nuclear Society (ANS) Standard 57.9. As in the transport mode of operations, the system will be capable of storing its full design capacity of spent fuel in consolidated rod form, assuming the age/burnup equivalent combinations described in Section 4.2.1.

\subsubsection{Temperature Limits}

The GA universal canister/cask system will be designed to ensure that spent fuel cladding temperatures do not exceed $375^{\circ} \mathrm{C}\left(707^{\circ} \mathrm{F}\right.$ ) in an inert atmosphere. This 11 mit will be met, assuming the age/burnup combination of spent fuel described in Section 4.2.1. and with PWR or BWR spent fuel as intact assemblies or as consolidated fuel rods. 
5. THE UNIVERSAL CANISTER SYSTEM

\subsection{SYSTEM DESCRIPTION}

5.1.1. General

GA's system for packaging and handling nuclear spent fuel uses a universal canister for containment of the spent fuel waste forms, including loading at the reactor pools, any and all transport or storage operations between the reactors and the repositories, and final disposal at those repositories. GA's principal canister design can operate efficiently in truck or rail transport casks, in storage casks or storage facility modules, or as part of the repository disposal package. The spent fuel accommodated by the canister can be in the form of intact fuel assemblies, consolidated fuel rods, or combinations of both.

GA's basic packaging and handling system uses a thin-walled canister which can be loaded with intact spent fuel assemblies or consolidated fuel rods at the reactor sites, then maintain a degree of containment of the spent fuel during any shipping or storage operations which occur prior to ultimate disposal operations at the repositories. Given an uncertain waste management system with at-reactor storage, Federal interim storage, and monitored retrlevable storage prior to ultimate disposal, the principal benefits of a canister system are twofold: operational time savings in spent fuel handling at different waste management facilities subsequent to its loading at the reactor, and (2) maintenance of a cleaner handling system because of the reduction of operations which involve bare fuel assemblies. These benefits will make the overall system easier to license, cheaper and more flexible to operate, and easier to decontaminate and decommission at the end of the system's life. The adoption of an integrated MRS system would reduce the 
benefits of a reactor-loaded canister unless storage was anticipated prior to fuel consolidation.

Two canister designs were identified during the study performed for this project. The first canister design, the "truck canister," is recommended as the principal design because it fulfills more varied functions and because it promises to offer fewer technical challenges in advancement of its design. The second canister design, the "rail canister," is included as an alternate design. This canister is more efficient in the rail mode of transport and it should be cheaper to construct than its equivalent number of truck canisters (six). Its drawbacks, compared to the truck cantster, include a limited ability to perform the full range of functions necessary for an ideal universal canister and greater technical challenges in advancing its design.

The remainder of this section will present and discuss the major elements in the GA packaging and handling system.

\subsubsection{Spent Fuel Canisters}

5.1.2.1. Principal Canister Design. The principal spent fuel canister has a modified circular-sector-shaped cross section and is designed for transport within a truck cask having a minimum cavity diameter of 25.0 in. or within a 100-ton rail cask having a minimum cavity diameter of $57.0 \mathrm{in.}$ and containing six canisters. An isometric view of this canister design is shown in Fig. 5.1-1. More details of the design are contained in Fig. 5.1-2.

The capacity of this canister is 3 PWR or 6 BWR intact fuel assemblies, or the equivalent of double that amount if a $2: 1$ ratio rod consolidation operation is performed. Following rod consolidation at the MRS facility, one canister can accommodate more than eight equivalent PWR fuel assemblies when loaded completely. This canister packing 

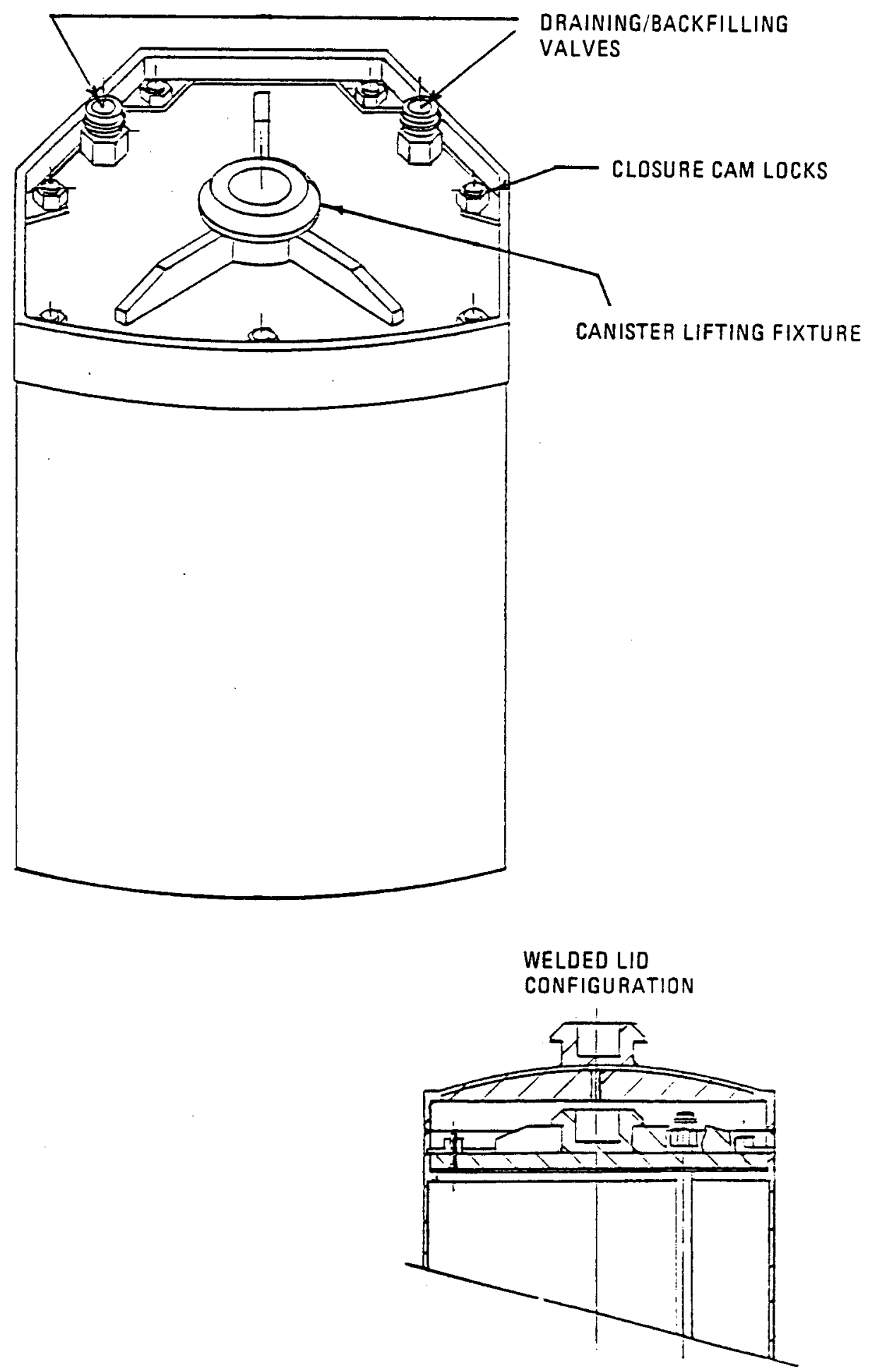

Fig. 5.1-1. Principal canister design 


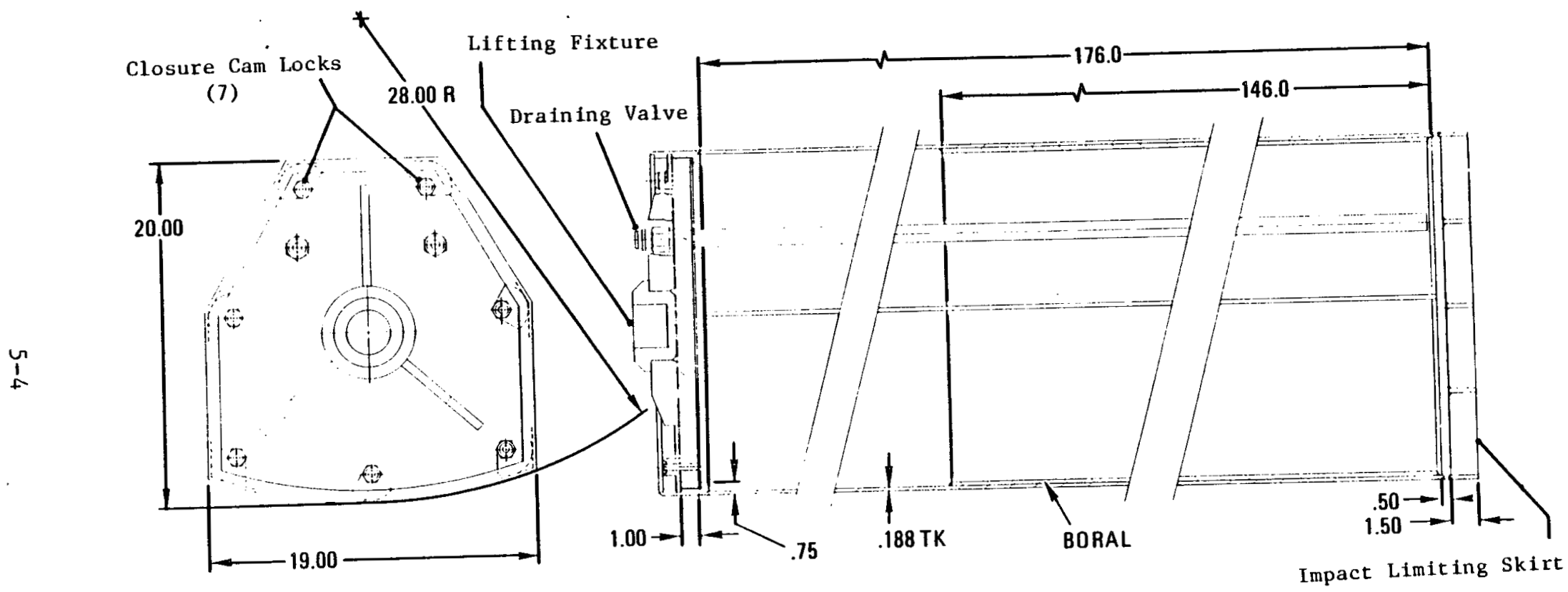

Fig. 5.1-2. Principal canister for GA packaging and handling system 
configuration would require the additional upper lid being welded to the canister body to meet the regulatory structural requirements.

The body and closure assembly for this canister can be constructed either of coated carbon steel or of stainless steel, depending on the missions selected for the design. If the final repository selected has a burial package design which is compatible with the GA principal canister design, stainless steel might be the material of choice because of its greater resistance to corrosion. Otherwise, carbon steel would be preferable because of 1 ts lower cost and better heat transfer. Both of these materials are considered during the discussions on structural analysis (Section 5.4.4) and cost estimating (Section 5.5) for this canister design.

Construction of this canister is relatively simple, the body being formed from a 0.188-in.-thick material joined by two longitudinal seam welds. The canister bottom is $0.50 \mathrm{in.} \mathrm{thick}$ and is welded in place followed by bottom stiffeners for strength and a bottom impact skirt to absorb energy from handling jolts. Because this canister is not designed to function as a Type A package (as defined in Ref. 5-1), it does not need to meet the 4-ft free drop test requirement specified in Ref. 5-1 for a Type A package of this size and weight.

The canister closure assembly is made from 1.0-in.-thick plate material, with stiffeners welded on for strength. Closure is attained at the reactor pools by placing the closure assembly on the canister body gasket ledge, then twisting and locking the seven cam locks on the top of the closure. Sufficient tightness is achieved by this arrangement to allow the draining of the water from the canister cavity, drying that cavity, and backfilling with a dry inert gas. The canister drying and backfilling operations are done through the two quick-disconnect valve fittings mounted on the closure assembly. One of these valves has a tube which extends to the bottom of the canister cavity to facilitate removal of the reactor spent fuel pool water. GA has experience in pool 
loading of reactor hardware canisters for disposal and considers this operation totally feasible.

The mechanical closure described provides sufficient tightness for at-reactor storage in a storage cask because the storage cask assumed for this task will provide the containment required by the applicable regulations. For longer term storage at an MRS facility, an additional lid can be welded onto the top of the canister to provide containment of the spent fuel in the MRS concrete storage casks or in the facility's storage modules. This additional lid covers all the through-canister fittings on the top head and it can be easily welded using automatic welding methods.

The canister has an aluminum-clad boron carbide lining around the inside of the walls and between the spent fuel assemblies which it carries. The boral between the fuel assemblies is necessary to ensure subcriticality conditions within the canister. The boral mounted on the walls surrounding the fuel assemblies guards against neutron rebound from the transport cask walls.

The principal canister is handled by a standard lifting lug mounted on the closure assembly. The load of the canister and the spent fuel that it carries is taken through the seven cam locking assemblies into the body of the canister. The structural analysis described in Section 5.4 .4 verifies that the thicknesses of the canister closure assembly, the seven cam locks, and the canister wall are adequate to meet the structural requirements of 10CFR71.45.

5.1.2.2. Alternate Canister Design. An alternate canister design was also identiffed during the course of the project. This canister is circular in shape and designed for rafl transport or storage cask missions only. The alternate canister has a capacity of 19 PWR or 44 BWR intact fuel assemblies or double that amount if consolidated fuel rods are to be transported or stored. This canister can operate in a rail cask at 
under the 100-ton weight limit when loaded with intact fuel assemblies. When fully loaded with consolidated rods, as in the MRS to repository transport leg, the cask/canister combination would fall well under the 150-ton limit set for this study.

An isometric view of this canister loaded with 19 PWR intact fuel assemblies is shown in Fig. 5.1-3. A plan view of this loading arrangement is shown in Fig. 5.1-4.

The body and closure assembly of this canister can be constructed of either coated carbon steel or stainless steel. The closure assembly is designed to be sealed by a bolted flange with double 0-ring seals. This arrangement would ensure sufficient tightness for all but at-reactor storage and transportation applications. For monitored retrievable storage, a welded lid arrangement would be devised to obtain the degree of tightness required.

The majority of the technical analysis work described in Section 5.4 applies to the principal canister design, but some of the work uses this design as a basis. The thermal analysis demonstrates this design's ability to handle its full capacity of spent fuel assuming the GA design basis fuel ( 7 year old/40,000 MWd/MTU). The center-to-center pitch of this design's spent fuel support basket ( 11.9 in.) is greater than that exhibited in the principal canister design. That fact along with the boronated stainless steel sleeves which surround each fuel assembly will ensure a lower criticality factor for this design than that calculated for the principal canister design in Section 5.4.2.

The shielding analysis described in Section 5.4.3 applies directly to this canister design. That leaves only the structural analysis to be done to demonstrate the feasibility of this canister design. With a fully loaded weight of 65,000 to 70,000 lb (assuming consolidated rods), the ability of this design to meet the structural limits would have to be carefully analyzed to verify the utility of the design. 
Lifting Pick-Up Points

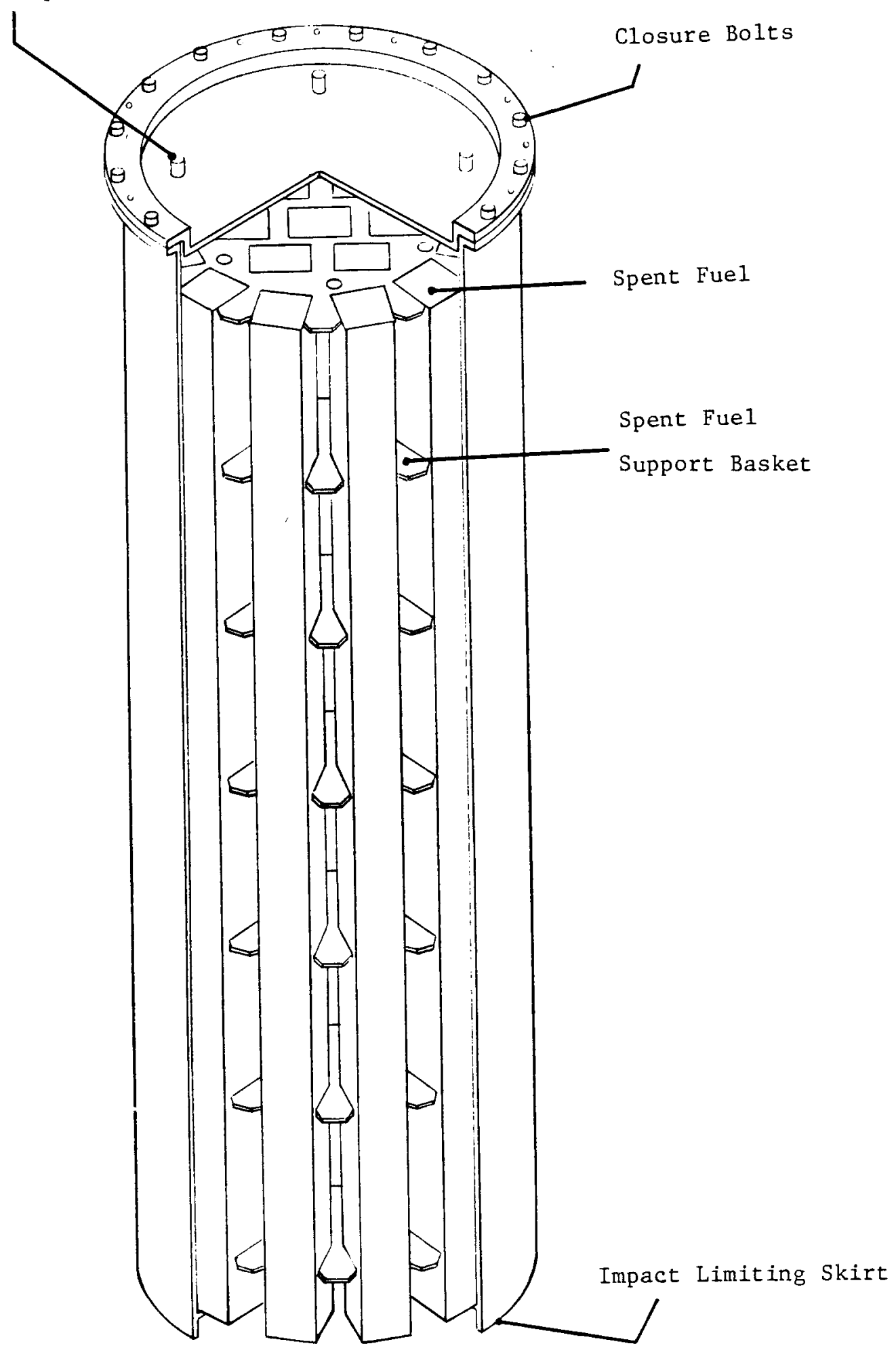

Fig. 5.1-3. Alternate canister design (rail canister) with 19 PWR spent fuel assemblies 


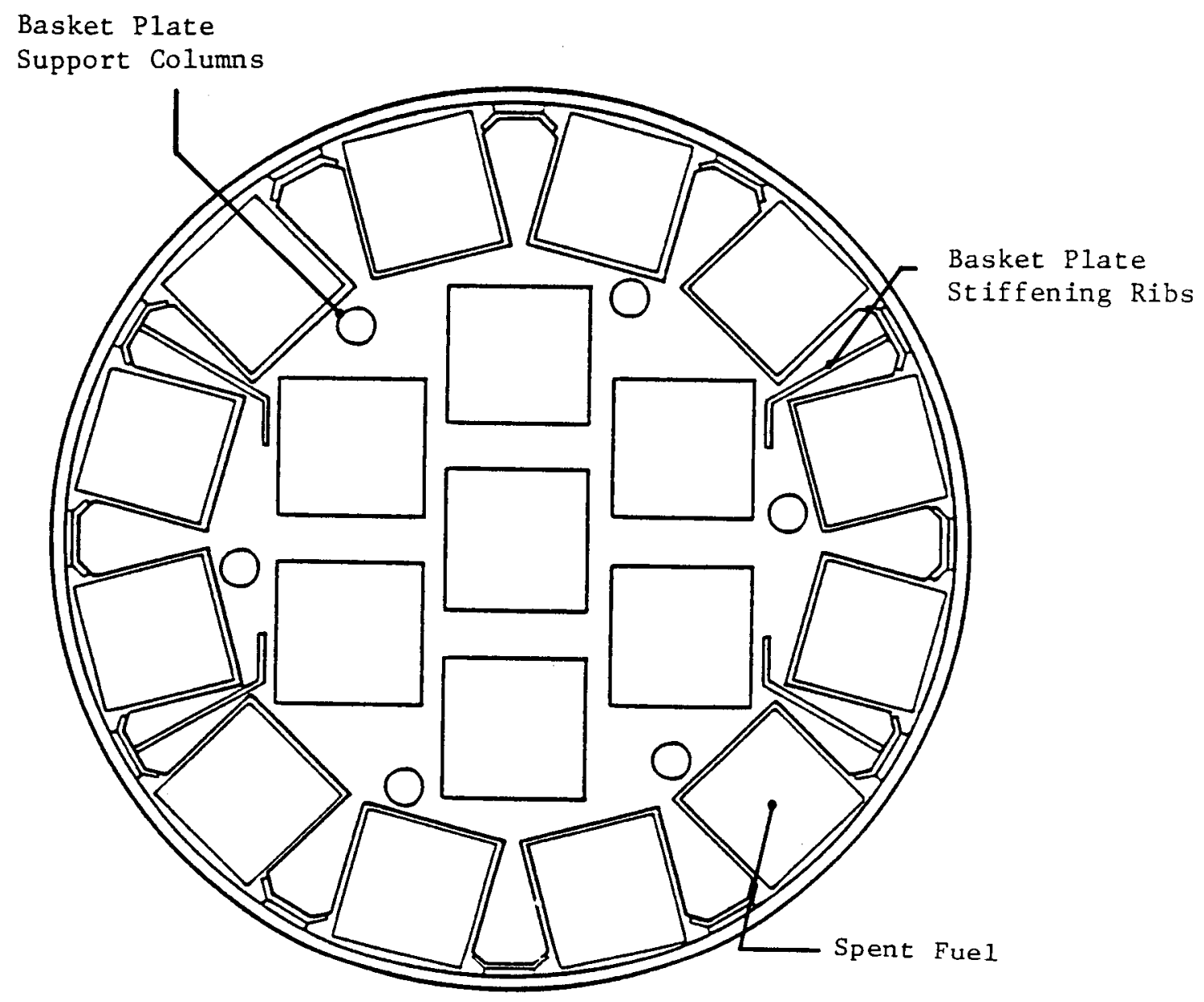
Fig. 5.1-4. Plan view of alternate canister design with 19 PWR
spent fuel assemblies 
The basic GA packaging and handling system does not use the alternate design canister. The principal design is used for truck and rail transport, short-term storage at the reactor sites, longer-term storage at an MRS facility, and, in some cases, as part of the burial package. It appears that a large rail canister is feasible, but more structural analysis is necessary to verify the head, wall, and bottom thicknesses required. Because the rail canister is not designed to function as a Type A package (as defined in Ref. 5-1), it does not need to meet the 1-ft drop requirement specified in Ref. 5-1 for a Type A package having this size and weight.

\subsubsection{Transportation Casks}

The truck and rail transportation casks used in this study are based on standard designs with cask cavity dimensions and shielding thicknesses adequate to handle the design basis spent fuel packaged in the principal and alternate canister designs described above. While any truck or rail cask having the cavity size and shielding required for the design basis fuel could be used for transporting the GA canisters, the technical analysis described in Section 5.4 assumes the use of the casks described here. The analysis conducted which assumes the use of these casks includes the shielding, criticality, and thermal areas. No formal structural analysis was conducted on these cask designs, but the structural component thicknesses used and the designs for impact limiters and cask closures are based on cask designs which meet the regulatory requirements in the structural area.

The cask designs utilize a depleted uranium (DU) liner for maximum capacity at minimum weight and size. DU has been used in casks designed and fabricated at GA for the last 20 years. Availability and workability were considered and have been factored into the cost estimates. It is believed that avallability of large castings in the U.S. would improve if a fleet of these casks were to be manufactured. 
5.1.3.1. Truck Transportation Cask. The truck transportation cask used in this study is designed for routine over-weight truck (OWT) operation. As such, the weight of the loaded cask is 1 imited to about $75,0001 \mathrm{~b}$ in order to meet a maximum total vehicle weight limit of about 105,000 $1 \mathrm{~b}$. The cask has 3-in.-thick steel walls, a 4-in.-thick steel bottom, and a 5-1n.-thick steel closure head which is fastened to the cask body with closure bolts. Double 0-ring seals mounted inboard of the closure bolts provide the containment for this cask.

In addition to the steel walls, head, and bottom of this cask, the remainder of the gamma shielding required for the cask is provided by DU shielding sleeves and disks. The cylindrical shlelding sleeve is placed inside of the cask's steel walls and held in position by a shear ring attached to a groove in the cask wall. The DU in the shielding sleeves and disks is encased in $0.375 \mathrm{in}$. thick stainless steel to provide beta shielding from the DU and for ease in handling and decontamination.

Neutron shielding is provided by a layer of borosilicone material mounted on the outside of the cask. Protection is provided to this material by a thin layer of stainless steel which is attached to the outside of the borosilicone. The thickness of this shielding varies from $6 \mathrm{in}$. on the cask wall adjacent to the spent fuel down to 3-in. at the head and upper impact limiter area.

An Inner Impact limiter is mounted between the upper shielding disk and the bottom of the closure head to reduce peak loads on the head and closure bolts during the regulatory-defined accident conditions. The cask body has fixed upper and lower impact limiters bullt in at its top and bottom to ensure that containment is maintained following the hypothetical accident. The cask's 0-ring seals are protected from the heat of the hypothetical fire by a 6-in.-thick thermal shield mounted on top of the closure head. 
Figure 5.1-5 illustrates this truck shipping cask with a spent fuel canister loaded inside of it. Table 5.1-1 lists the major features and dimensions of this cask. The weights calculated for the truck cask and its contents are listed in the cask/canister weight summary table (Table 5.1-3) which is presented in the following section.

5.1.3.2. Ral1 Transportation Cask. The rail transportation cask used in this study is designed to handle a maximum amount of intact spent fuel assemblies which are the equivalent of seven-year old 40,000 MWd/ MTU burnup at a total cask weight of 100 tons. The cavity of this cask can hold six principal design canisters (having the capacity of three PWR or six BWR intact fuel assemblies each) or one alternate design canister (having the capacity of 19 PWR or 44 BWR intact fuel assemblies). Figure 5.1-6 illustrates this cask with an alternate design canister inside of it. Figure 5.1-7 illustrates the arrangement of six principal design canisters in the rall cask.

The rail transportation cask has many of the design features found in the truck cask. The rail cask has 5-1n.-thick steel walls, a 5.5-in. steel bottom and a 6-1n.-thick steel closure head. These thicknesses were selected to ensure structural integrity following the hypothetical regulatory accident sequence. Additional gamma shielding is provided by DU shielding sleeves and disks mounted inside of the cavity defined by the cask's steel structure.

Like the truck cask, containment for the rail cask is provided by a bolted closure head with two 0-ring seals. Fixed external impact limiters built into each end of the cask and an internal impact limiter mounted between the canisters and the bottom of the closure head reduce peak loads on the cask's structural components during a hypothetical accident. The containment seals are protected against high temperature from fire by a thermal shield mounted on top of the closure head. 


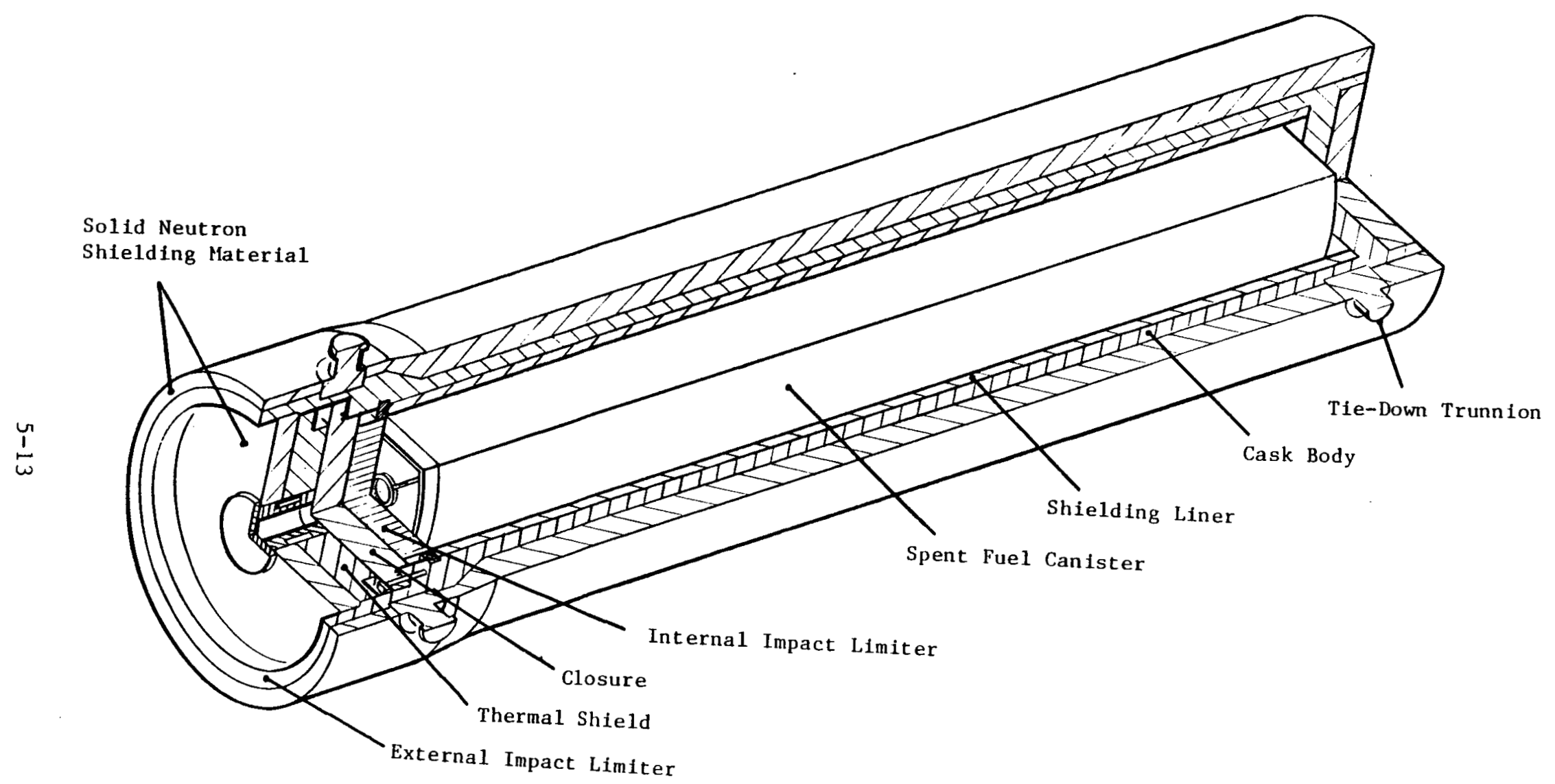

Fig. 5.1-5. Principal canister design in truck shipping cask 
TABLE 5.1-1

TRUCK SHIPPING CASK

\begin{tabular}{|c|c|}
\hline Minimum waste age & $5 \mathrm{yr} / 30,000 \mathrm{MWd} / \mathrm{MTU}$ \\
\hline Maximum burnup & $7 \mathrm{yr} 40,000 \mathrm{MWd} / \mathrm{MTU}$ \\
\hline Combinations & $10 \mathrm{yr} / 55,000 \mathrm{MWd} / \mathrm{MTU}$ or equivalent \\
\hline \multicolumn{2}{|l|}{ Overall size } \\
\hline Outside diameter, top & $53.1 \mathrm{in.}$ \\
\hline Outside diameter, bottom & $49.1 \mathrm{in}$. \\
\hline Overall length & 225.7 in. \\
\hline \multicolumn{2}{|l|}{ Cavity size } \\
\hline Inside diameter & $25.0 \mathrm{in.}$ \\
\hline Inside length & $184.0 \mathrm{in}$. \\
\hline \multicolumn{2}{|l|}{ Shielding } \\
\hline Gamma type & $\mathrm{DU} / \mathrm{stee} 1$ \\
\hline \multicolumn{2}{|c|}{ Equivalent steel thickness } \\
\hline Cask side, bottom & $10.7 \mathrm{in.}$ \\
\hline Cask top & $11.0 \mathrm{in.}$ \\
\hline Neutron type & Borosilicone \\
\hline Thickness & 6.0 \\
\hline Type of containment & Bolted closure \\
\hline Seals & Double 0-ring \\
\hline Cavity atmosphere & Dry helium \\
\hline \multicolumn{2}{|l|}{ Impact limiters } \\
\hline External type & Steel fixed ring \\
\hline Internal type & Crushable honeycomb \\
\hline \multicolumn{2}{|l|}{ Trunnions } \\
\hline Lifting, top & 4 at $90 \mathrm{deg}$ \\
\hline Tie-down, bottom & 2 at $180 \mathrm{deg}$ \\
\hline
\end{tabular}




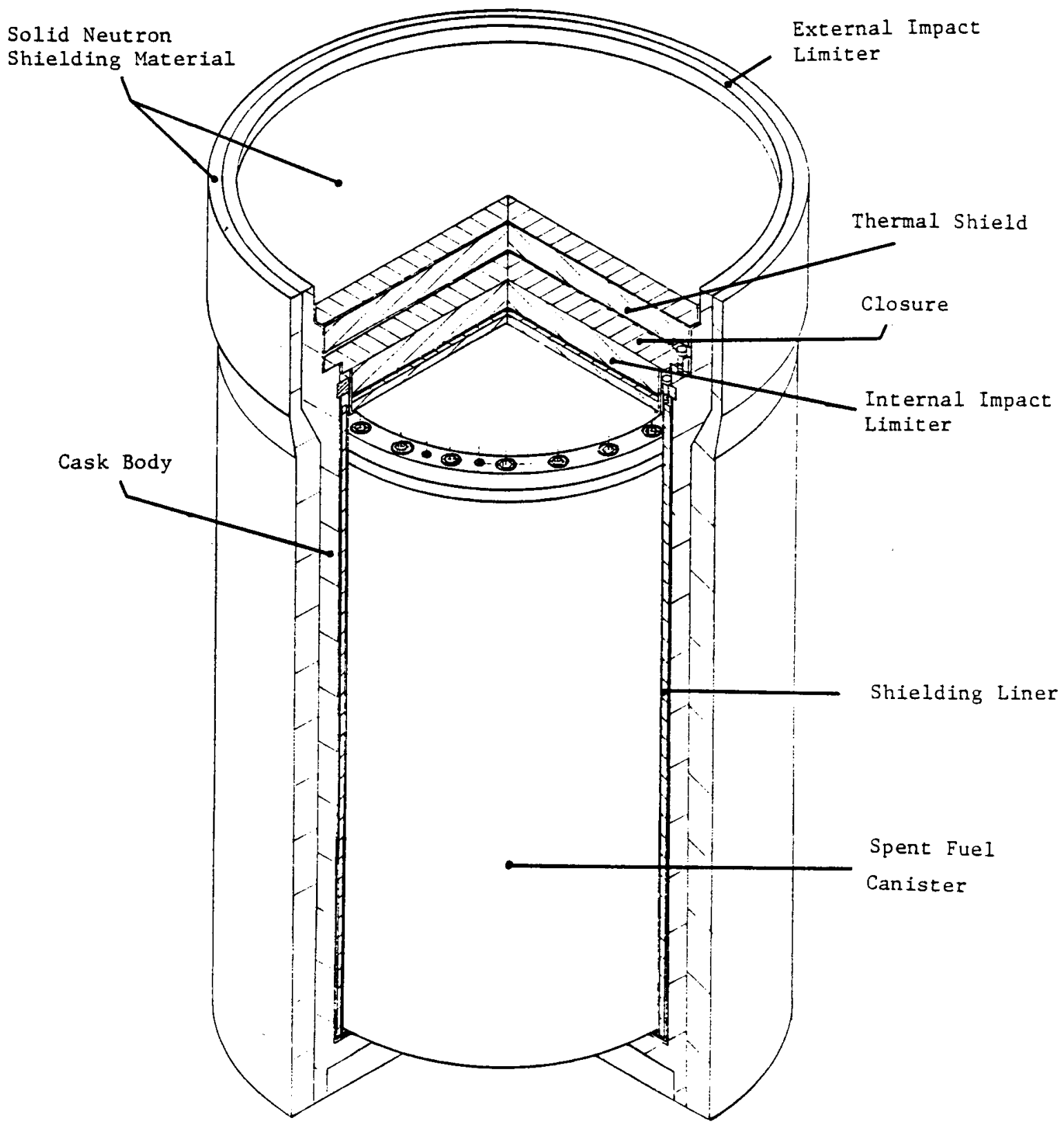

Fig. 5.1-6. Alternate canister design in rail shipping cask 


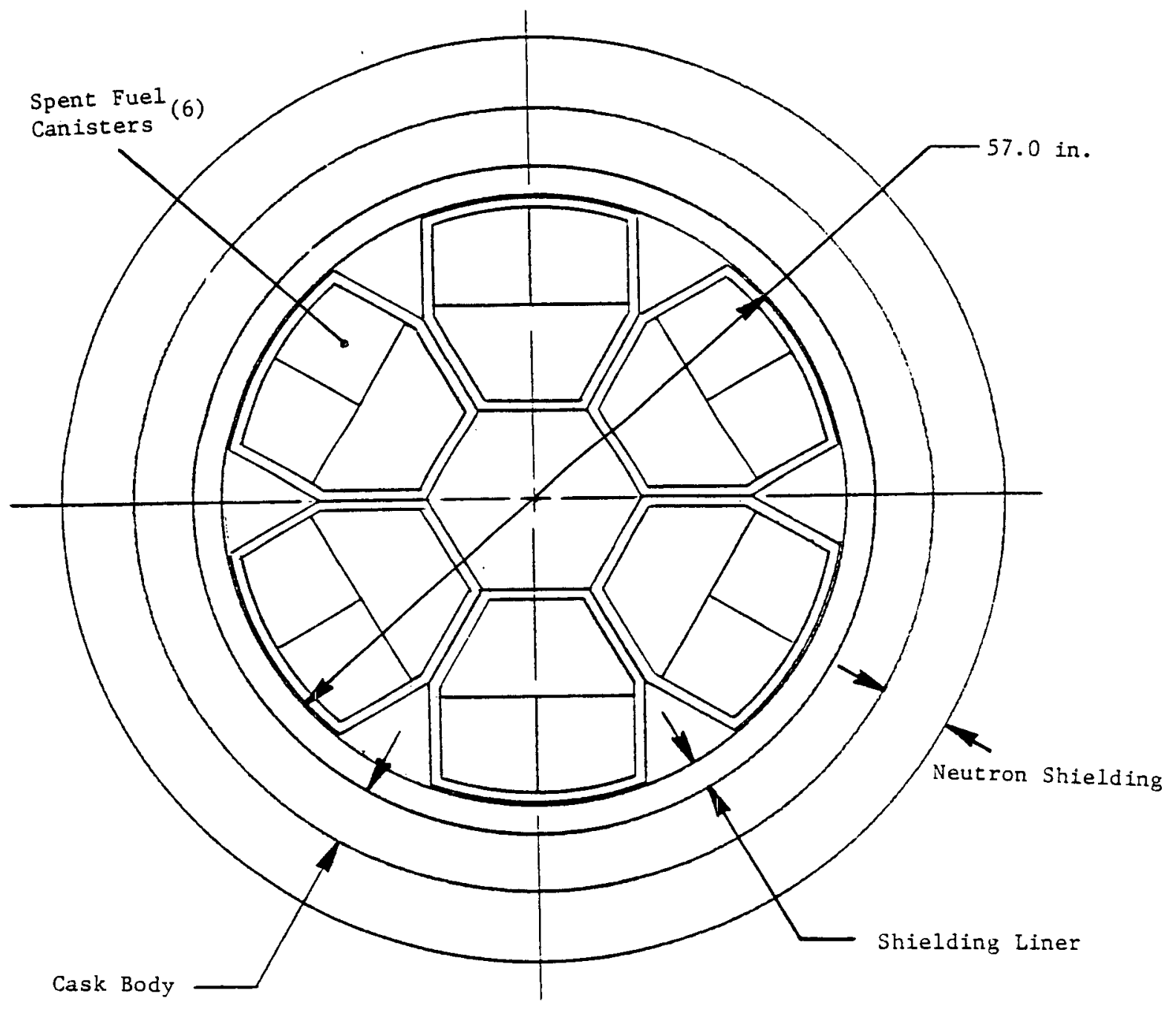

Fig. 5.1-7. Arrangement of six principal design canisters in a rail shipping cask, a storage cask, or a storage module (support basket not shown) 
Table 5.1-2 lists the major features and dimensions of the rail cask. Table 5.1-3 1ists the weights calculated for all cask/canister combinations used in the study, namely:

1. Truck (principal) canister in truck cask.

2. Six truck canisters in rail cask.

3. Rail (alternate) canister in rail cask.

Note that the truck cask can ship its design capacity of intact fuel assemblies or consolidated rods at about the 75,000 $1 \mathrm{~b}$ target 1 imit for this cask. The rail cask can ship its design limit of intact fuel assemblies with a margin of between $5 \%$ and $8 \%$ below the 100-ton cask welght limit. This cask can carry consolidated rods, likely to be loaded at the MRS facility, at well below the 150-ton allowable weight for the loaded cask on the MRS facllity to repository transport leg.

The payload of the universal canister/cask system can be compared to the payload of similar truck and rail casks which would use round canisters. If the round canister is to be universal, it must be capable of holding intact or consolidated fuel and be usable in both truck and rail casks. If the rail cask's internal diameter were increased by approximately 3 in., it could hold seven 19-in.-i.d. canisters, each holding two PWR assemblies as shown in Fig. 5.1-8. Therefore, a larger cask would be required to ship 14 PWR assemblies than 18 PWR assemblies in the universal canister/cask system. The rail cask can hold $30 \%$ more intact fuel and the truck $50 \%$ more intact fuel with the universal canister.

For consolidated fuel the 19-in.-1.d. canister would hold rods from less than four PWR assemblies, whereas the universal canister can hold rods from up to eight PWR assemblies, which would approximately double the capacity for a smaller-diameter cask. 
TABLE 5.1-2

RAIL SHIPPING CASK
Minimum waste age
Maximum burnup
Combinations
Overall size
Outside diameter, top
Outside diameter, bottom
Overall length
Cavity size
Inside diameter
Inside length
Shielding
Gamma type

Equivalent steel thickness

Cask side, bottom

Cask top

Neutron type

Thickness

Type of containment

Seals

Cavity atmosphere

Impact limiters

External type

Internal type

Trunnions
Lifting, top
Tie-down, bottom

$5 \mathrm{yr} / 30,000 \mathrm{MWd} / \mathrm{MTU}$

$7 \mathrm{yr} / 40,000 \mathrm{MWd} / \mathrm{MTU}$

$10 \mathrm{yr} / 55,000 \mathrm{MWd} / \mathrm{MTU}$ or equivalent

85.6 in.

84.0 in.

228.6 in.

57.0 in.

184.0 in.

$\mathrm{DU} /$ steel

11.1 in.

$12.0 \mathrm{in.}$

Borosilicone

6.2 in.

Bolted closure

Double 0-ring

Dry helium

Steel fixed ring

Crushable honeycomb

4 at $90 \mathrm{deg}$

2 at $180 \mathrm{deg}$ 
TABLE 5.1-3

CASK/CANISTER WEIGHT SUMMARY

\begin{tabular}{|c|c|c|c|c|}
\hline & & $\begin{array}{c}\text { Truck Canister in } \\
\text { Truck Cask } \\
\text { (1b) }\end{array}$ & $\begin{array}{c}6 \text { Truck Canisters in } \\
\text { Rail Cask } \\
\text { (1b) }\end{array}$ & $\begin{array}{l}\text { Rail Canister in } \\
\text { Rail Cask } \\
\text { (1b) }\end{array}$ \\
\hline 1 . & Cask body (steel) & 24,700 & 79,100 & 79,100 \\
\hline 2. & $\begin{array}{l}\text { DU liners } \\
\text { a. Steel casings } \\
\text { b. DU shielding }\end{array}$ & $\begin{array}{r}3,900 \\
26,100\end{array}$ & $\begin{array}{r}8,600 \\
41,200\end{array}$ & $\begin{array}{r}8,600 \\
41,200\end{array}$ \\
\hline 3. & Borosilicon & 10,700 & 20,900 & 20,900 \\
\hline 4. & Miscellaneous & 300 & 800 & 800 \\
\hline & Total empty cask & 64,700 & 150,600 & 150,600 \\
\hline 5. & No. canisters/cask & 1 & 6 & 1 \\
\hline 6. & Canister weight, each & 1,300 & 1,300 & 6,800 \\
\hline 7. & Internal basket & -- & -- & 5,100 \\
\hline 8. & Total canister weight & 1,300 & 7,800 & 11,900 \\
\hline & $\begin{array}{l}\text { Spent fuel weight } \\
\text { a. Intact PWR SFAs } \\
\text { b. } 2 / \text { l consolidated } \\
\text { c. Maximum rods }\end{array}$ & $\begin{array}{r}4,400 \\
8,700 \\
11,600\end{array}$ & $\begin{array}{l}26,100 \\
52,200 \\
69,600\end{array}$ & $\begin{array}{l}27,600 \\
55,100 \\
55,100\end{array}$ \\
\hline 10. & $\begin{array}{l}\text { Total loaded weight } \\
\text { a. Intact SFAs } \\
\text { b. } 2 / 1 \text { consolidated } \\
\text { c. Maximum rods }\end{array}$ & $\begin{array}{l}71,400 \\
75,700 \\
\quad \mathrm{~N} / \mathrm{A} \\
(\mathrm{b})\end{array}$ & $\begin{array}{l}184,500(a) \\
210,600(a) \\
228,000^{(a)}\end{array}$ & $\begin{array}{l}190,100(a) \\
217,600(a) \\
217,600\end{array}$ \\
\hline
\end{tabular}

(a) Loaded cask $11 \mathrm{mit}$ from MRS is 150 tons.

(b) Truck cask is only used in shipments originating at reactors. 


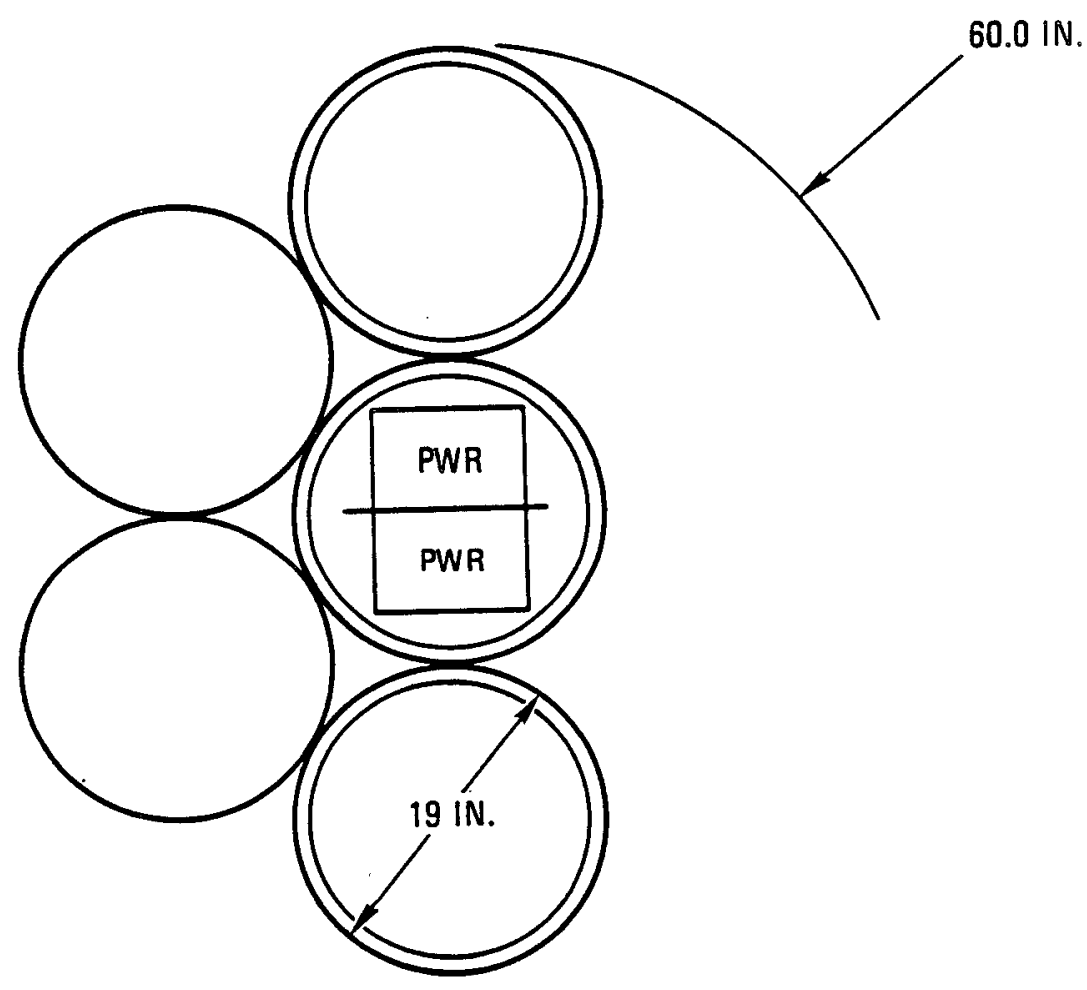

Fig. 5.1-8. Rail cask's diameter increased to hold seven 19-in.-i.d. canisters 


\subsubsection{At-Reactor Storage Cask}

The at-reactor storage cask used for this study is assumed to be the same design used in the storage study described in Ref. 5-2. This cask is generally a thick-walled cast-iron design with borated-waterfilled tubes mounted to the outside of the cask to provide the necessary neutron shielding.

Figure 5.1-9 shows an illustration of this cask with dimensions to support the specific requirements of the study described in Ref. 5-2. For the current study, the dimensions were slightly modified to allow accommodation of six truck canisters or one rail canister for storage. The modifications made are reflected in the cost estimate done for this cask (contained in Appendix D.1).

The main structure of the storage cask is a closed-bottom cylinder topped with a bolted-ring flange for fastening the cask lid. Both cask body and closure lid are constructed of modular cast iron of sufficient thickness to provide the gamma shielding necessary for storing spent fuel which is the equivalent of seven years old with a burnup of 40,000 MWd/MTU. The surfaces of the cask are sandblasted and epoxyresin coated for ease of decontamination in case of an emergency. During normal operations, a protective skirt is attached to the outside of the cask to minimize contamination problems during loading and unloading in the reactors' pools.

The cylindrical portion of the storage cask has external cast iron fins running longitudinally along its length to dissipate the decay heat from the spent fuel being stored. The gaps between these fins contain steel tubes which are filled with borated water to provide the necessary neutron shielding. Each tube contains an air-filled hose to accommodate expansion of the water as it becomes warmed. The normal operating pressure in each tube is about one atmosphere. These neutron shielding 


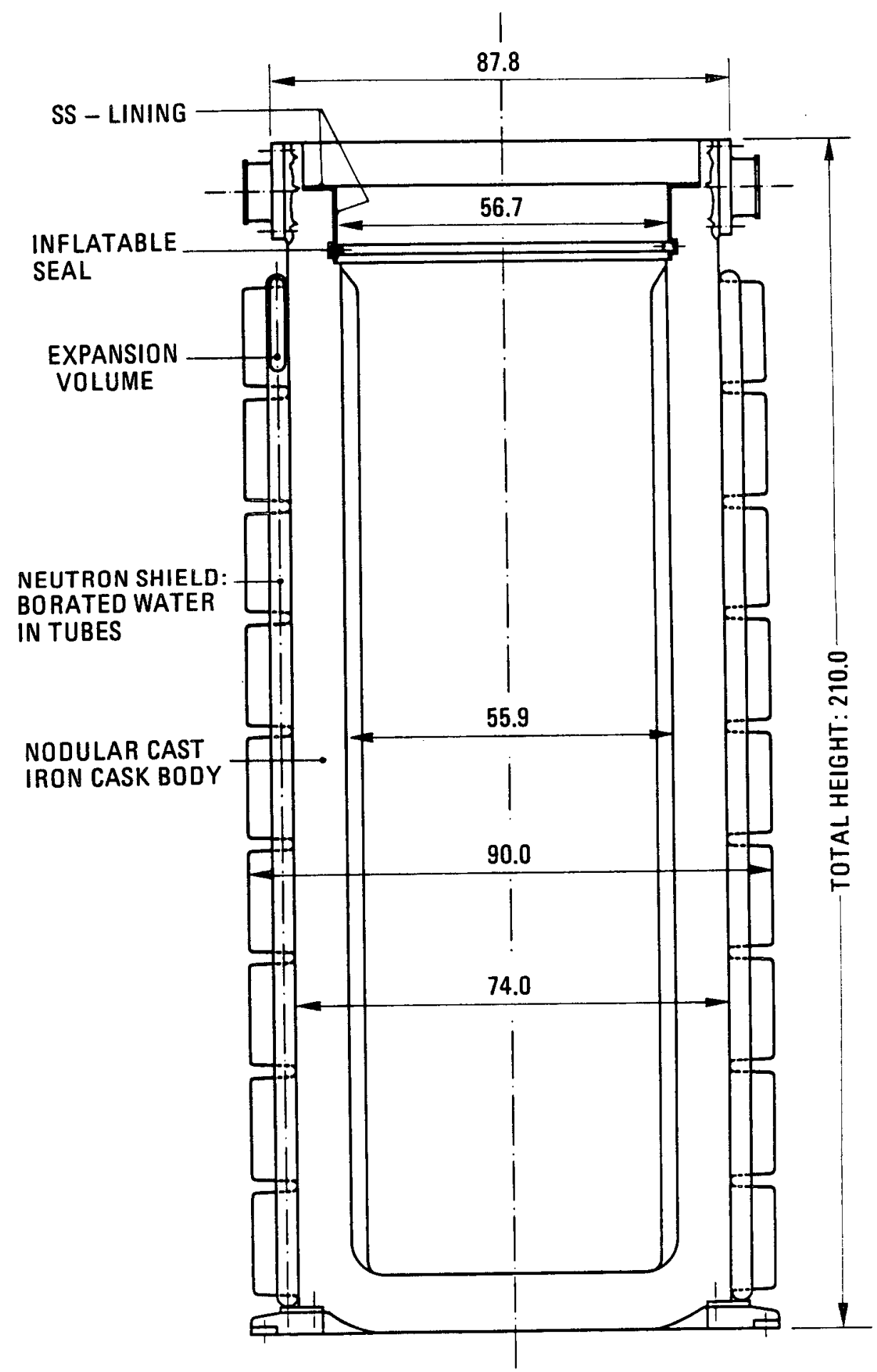

Fig. 5.1-9. Typical at-reactor storage cask (dimensions in inches) 
tubes are connected to the cask by efght circumferential bands, each of which fits into recesses in the fins along the side of the cask.

As is the case for the transportation casks used in this study, any storage cask can be used for at-reactor storage as long as it has a large enough cavity to accommodate the cantster designs and it has the shielding and thermal performance necessary for the age and burnup of the fuel in this study. The cask described was assumed for the current study. The cost estimate of $\$ 500,000$ for this storage cask is developed in Appendix D.1.

\subsubsection{Auxiliary Equipment}

Handling of the canisters and transport casks at the repositories or at an MRS facility will be accomplished through utilization of the standard equipment assumed to be provided there. This includes standard cranes having the capacity to handle 150-ton casks, remote manipulators, Inspecting and cleaning equipment, remote welding equipment, etc. Nothing spectal is seen to be needed for handling the GA canisters beyond that provided by the reference system. For that reason, no costs are included in this study for special handling equipment for the universal canister concept.

One goal of the universal canister concept is to minimize the effects at the reactors caused by the introduction of the canisters into the system. The canisters are designed with standard handling fixtures at their tops, as are the transportation and storage casks assumed in this study. The following items are assumed to be available at the reactor pools for loading or unloading the canisters prior to shipment or storage:

1. A crane with the capacity to transfer the appropriate cask/ canister combination (truck or rall size) into and out of the pool. 
2. A supply of compressed air for removal of water from the loaded canisters and casks.

3. A vacuum pump for the vacuum drying of the loaded canisters.

4. A supply of demineralized water for initial filling of the cask/canister and the protective skirt/cask interspaces.

5. A supply of helium for back-filling the dried, loaded spent fue1 canisters.

6. A connection to the existing off-gas system for control of the helium during unloading operations.

These items, along with tools to tighten the canister lid locking cam mechanism (for the truck canister), to tighten the canister lid bolts (for the rail canister) while under water, or to connect the draining/ backfilling valves on the canisters are disregarded from a cost standpoint for this study for two main reasons:

1. A11 or most of the items are assumed to be avallable at the reactors.

2. Except for the crane, the cost of these items is quite sma11 compared with the costs estimated for the casks and canisters.

\subsection{UNIVERSAL CANISTER SELECTION}

A careful analysis of the spent fuel inventory in conjunction with an evaluation of the mission requirements of the waste management system has shown that certail benefits will result from the use of a universal canister during the handling, transport and storage of spent fuel assemblies. Following this determination that the waste management system would benefit from the use of a universal canister, the functional 
requirements and design criteria for such a universal canister were developed as documented in Section 4.. Then, based on the above requirements and criteria, the size, shape, and materials of fabrication for the universal canister were able to be selected.

\subsubsection{Universal Canister Size}

Since $30 \%$ of the spent fuel assemblies will be transported from reactors that are not sultably equipped to handle a rail cask, there is a need for truck casks and therefore the universal canister must be compatible with a truck cask. Studies have shown that a truck cask with adequate shielding to limit the external radiation dose rate as required by U.S. Department of Transportation (USDOT) regulations will be able to transport one PWR fuel assembly or three BWR fuel assemblies at a gross vehicle weight (GVW) of 80,000 lb or less. The cask shielding in this case assumes that the spent fuel being transported is the equivalent of seven years out-of-reactor with 40,000 MWd/MTU burnup. Eighty thousand pounds is the maximum GVW for travel on the interstate highway system of the United States without permits. This limitation would result in nearly 1000 trips per year to transport PWR fuel assemblies, assuming the PRDA project inventory and over 500 trips per year to transport BWR fuel assemblies. Since a reduction in the number of trips will reduce the exposure of the transport system to the potential accident environment and should also result in a cost savings, it was decided to investigate a larger canister and matching transport cask as part of the canister selection process.

Any transport system with a GVW in excess of $80,000 \mathrm{lb}$ requires a permit to travel in each state on 1 ts route. These state-issued permits become more difficult to obtain as the weight increases. Permits are relatively routine in most states for a GVW up to $108,0001 \mathrm{~b}$; therefore, this became the reference transport system target weight for selecting the size of the universal canister. This higher weight restriction will allow the use of a canister which can hold three PWR intact fuel 
assemblies or six BWR intact fuel assemblies. This size canister will reduce the number of trips required for the PWR fuel assemblies by a factor of three and will reduce the number of trips required for the BWR fuel assemblies by a factor of two when compared to a properly shielded canister/cask combination operating at a maximum GVW of $80,0001 \mathrm{~b}$.

Overweight shipments are not without restrictions. An overweight permit must be obtained for each trip in each state. Overweight vehicles in many eastern states are not allowed to travel during the hours of darkness or on weekends or holidays. This restriction will limit the total number of hours available during the year and will require careful scheduling to optimize transport system utilization. In spite of these restrictions, many shipments of radioactive material are currently being made using transport systems with a GVW of about 108,000 $1 \mathrm{~b}$. Thus, the benefits of an overweight transport system making fewer trips at substantive cost savings justifies accepting the associated operating restrictions.

The canister finally selected for this study operates at a maximum GVW of 105,000 1b. To account for the reduction of travel hours available in some states as a result of shipping at a GVW in excess of $80,0001 \mathrm{~b}$, the average speed of the truck shipments was reduced to 25 miles per hour (from 35 miles per hour) in the economic analysis which was performed. This had a less than $10 \%$ effect on transportation costs.

\subsubsection{Universal Canister Shape}

The ideal universal canister must fit within the smallest possible truck cask, and multiple canisters must fit efficiently into the rail cask. This second requirement suggested that the GA universal canister should have the shape of a sector of a circle. Currently the rail cask has a weight 11 mit of 100 tons imposed by the capacity of many reactor cranes. Shielding considerations limit the capacity of such a cask to 
approximately 20 PWR fuel elements. These considerations led to a universal canister which is a 60-deg sector of a circle so that six canisters will fit efficiently into the rail cask. This sector shaped canister was then modified to minimize the size of the truck cask used for transport by removing the unused space at the apex and where the sides meet the circular portion. This modified sector shape will fit into a truck cask with an inside diameter of 25.0 in., and six of these universal canisters will fit into a rail cask with an inside diameter of 57.0 in.

The modified circular-sector-shaped canister was selected after investigation of several round and rectangular canisters. The gain in efficiency of the modified circular sector canister is felt to more than compensate for the small penalties estimated in the areas of canister fabrication and handling.

\subsubsection{Universal Canister Materials}

The material selected for the fabrication of the universal canister will depend on the final mission selected. Candidate materials are carbon steel and stainless steel. If corrosion is not a problem and/or suitable protective coatings can be applied, the use of carbon steel for the fabrication of the universal canisters will significantly reduce the initial cost. Another factor which may require consideration during $t e$ mission evaluation is the requirement for decontamination of the external surface of the universal canister. Stainless steel is generally considered easier to decontaminate; however, for a limited number of decontamination cycles, the use of a suitable protective coating can make carbon steel an acceptable material. If the universal canister is emplaced in the repository as part of the waste package, the repository requirements may dictate the material selection. 


\subsection{DESCRIPTION OF OPERATIONS}

All spent fuel assemblies will be placed into a universal canister at the reactor prior to at reactor storage in casks or transport from the reactor in either a truck cask or a rail cask. The spent fuel assemblies can remain in the universal canister during any interim storage, during subsequent transport, and during the final emplacement at the repository.

\subsubsection{Universal Canister Loading}

Each universal canister will be filled with three PWR fuel assemblies or six BWR fuel assemblies depending on the reactor type. If the utility has consolidated its fuel into square canisters, these canisters can be loaded directly into the universal canister. Consolidation of fuel for direct loading into the canister ar-reactor is not considered in this concept. Canister loading will be accomplished in the spent fuel storage pool by lowering a water-filled empty canister into the pool and then placing the spent fuel assemblies into the canister. Depending on space availability in the reactor pool, any number of canisters can be loaded with spent fuel assemblies in advance of a spent fuel shipping campaign, thus shortening the time required to receive, load, and dispatch a transport cask, especially a rail cask. The lid for the universal canister has two penetrations with quick disconnects. One of the disconnects is attached to a tube which extends to the bottom of the canister. When compressed air is introduced into the other disconnect, the water in the canister is forced out through the tube. After the water has been removed, the canister can be backfilled with an inert gas and the hoses removed from the disconnects. An elastomer seal, located between the canister body and the canister lid, is designed to prevent the ingress of water while the canister is in the reactor fuel pool prior to its transfer to the transport cask. 
If contamination of the canister external surfaces is a problem in a particular reactor pool, the canisters would be preloaded in the storage or shipping cask and the cask would be filled with clean water prior to submersion in the pool. A flow of clean water into the cask is maintained while the cask is in the pool.

\subsubsection{Universal Canister Transport}

The size and shape of the universal canister has been optimized for efficient transport in either a truck cask or a rail cask. The universal canister is not designed to provide containment or physical protection of the radioactive material in the spent fuel assemblies since these requirements are satisfied by the transport casks. A single canister is transported by a truck cask which will operate with permits, since the GVW will exceed 80,000 1b. A rail cask will transport six canisters. Five or more rall casks will be part of a dedicated nuclear train during transport from the reactor.

\subsubsection{Universal Canister Storage}

For the case where the nuclear waste management system requires that spent fuel assemblies be placed in interim storage, the universal canister can provide containment and criticality control. Before the canister is placed in a storage position, a second lid is welded to the top of the canister, aoove the $11 d$ and elastomer seal that was installed at the reactor. The spent fuel assemblies are now contained within an al1-welded canister. Plates of boron-aluminum (boral) or borated steel used to fabricate the spacers within the canister ensure that any number and any array of canisters will remain subcritical. Six of the universal canisters will fit in a concrete storage cask with the same inside diameter as the rall cask used for transportation. 


\subsubsection{Universal Canister Burial}

The universal canister can be used as a part of the waste burial package at the repository in a variety of ways. If the canister has been held in interim storage it is already a fully welded containment vessel which can be placed in an overpack as required and then emplaced in a repository tunnel. For those universal canisters that have been transported directly to the repository from the reactor, it may be necessary to add the welded-on containment lid. At some repositories it may be desirable to emplace canisters containing consolidated fuel rods or a mixture of intact fuel assemblies and consolidated fuel rods. In this case, one or more of the intact fuel assemblies would be removed from the canister and that section of the spacer filled with consolidated fuel rods, and then the containment lid would be welded in place.

\subsection{ENGINEERING ANALYSIS RESULTS}

This section presents a summary of the results found during performance of the engineering analysis for the PRDA study. The analysis consists of separate studies performed to confirm equipment capability in the thermal, criticality, shlelding, and structural fields. The following subsections describe the highlights and results of the separate studies performed. Further discussion and details of the studies are contained in Appendix $\mathrm{C}$ of this report. Consolidated fuel rods were considered during the thermal analysis performed.

\subsubsection{Therma1 Analysis}

A description of the methods used in the thermal analysis is contained in Section C. 1 of Appendix C to this report. The results of the analysis are summarized in Table 5.4-1. This table shows that the two canister designs maintain their spent fuel below the $375^{\circ} \mathrm{C}$ maximum

allowable value for both intact and consolidated fuel rod cases. Case 3 (rail canister with the equivalent of 38 SFAs as consolidated rods) 
TABLE 5.4-1

MAXIMUM PREDICTED CLADDING TEMPERATURES FOR CANISTERED SPENT FUEL IN A RAIL TRANSPORTATION CASK

\begin{tabular}{|c|c|c|c|c|c|c|c|}
\hline Case & Spent Fue1 Form & $\begin{array}{l}\text { Cask } \\
\text { o.d(a) } \\
(\mathbf{i n .})\end{array}$ & $\begin{array}{l}\text { Type and } \\
\text { No. of } \\
\text { Canisters }\end{array}$ & $\begin{array}{c}\text { Equivalent No. } \\
\text { of SFAs (b) } \\
\text { Per Cask }\end{array}$ & $\begin{array}{l}\text { Fuel Age }(c) \\
\text { and Burnup } \\
\text { (yr/MWd/MTU) }\end{array}$ & $\begin{array}{l}\text { Decay Heat } \\
\text { per SFA } \\
(\mathrm{kW})\end{array}$ & $\begin{array}{l}\text { Maximum } \\
\text { Cladding } \\
\text { Temperature } \\
\left({ }^{\circ} \mathrm{C}\right)\end{array}$ \\
\hline 1 & Intact SFAs ${ }^{(b)}$ & \multirow{2}{*}{$\begin{array}{l}84.0^{(\mathrm{d})} \\
84.0^{(\mathrm{d})} \\
84.0^{(\mathrm{d})}\end{array}$} & 1 -rail & 19 & $7 / 40,000$ & 0.7936 & 294 \\
\hline 2 & Intact SFAs $(b)$ & & $1-\mathrm{ra11}$ & & $7 / 40,000$ & 0.7936 & 278 \\
\hline 4 & Intact SFAs & $84.0^{(d)}$ & 6-truck & 18 & $7 / 40,000$ & 0.7936 & 321 \\
\hline 5 & Consolidated rods & $84.0^{(\mathrm{d})}$ & 6-truck & 36 & $7 / 40,000$ & 0.7936 & 291 \\
\hline 6 & Consolidated rods & $84.0(\mathrm{~d})$ & 6-truck & 36 & $10 / 33,000$ & 0.5656 & 230 \\
\hline $6 a$ & Consolidated rods & $131.2^{(f)}$ & 6 -truck & 36 & $10 / 33,000$ & 0.5656 & 388 \\
\hline 7 & Intact SFAs & $84.0^{(d)}$ & 6-truck & 18 & $10 / 33,000$ & 0.5656 & 267 \\
\hline
\end{tabular}

\footnotetext{
(a) Excludes 2.88-in. height of fins.

(b) SFA = spent fuel assembly (PWR type assumed for analysis).

(c) Years out-of-reactor/megawatt days per metric ton of uranium.

(d) Helium gas atmosphere assumed inside of canister and cask.

(e) Ambient air temperature assumed to be $38^{\circ} \mathrm{C}\left(100^{\circ} \mathrm{F}\right)$.

(f) Concrete storage cask with argon gas inside of canister and cask.
} 
results in little temperature margin remaining when seven year old 40,000 MWT/MTU burnup spent fuel is assumed. Removal of the center box of fuel rods (reducing capacity to 36 equivalent SFAs) would reduce the maximum temperature of this case without much cost in capacity if more margin were desired between the maximum calculated temperature and the maximum allowable temperature. An illustration of this arrangement is shown in Fig. $\mathrm{C}-2$ in Section $\mathrm{C} .1$ of Appendix $C$.

The truck canister cases examined all have comfortable margins between their maximum calculated temperatures and the $375^{\circ} \mathrm{C}$ allowable value. An interesting discovery in this analysis is that the consolidated rod loading of this canister results in a lower peak cladding temperature than the intact fuel assembly loading (compare Case 4 to Case 5 in Table 5.4-1). This result occurs because the conduction heat path made possible with the consolidated rod form more than compensates for the loss of the natural convection path, which is a minor contributor in the intact SFA case for this canister design.

The difference between seven-year-old 40,000 MWd/MTU burnup spent fuel and 10-year-old 33,000 MWd/MTU burnup spent fuel is illustrated by Cases 5 and 6 . In the consolidated fuel rod case, the maximum cladding temperature increases by $25 \%$ when the younger, higher burnup spent fue 1 , which is the design basis for this study, is substituted for the widely used "nominal" value spent fuel, which represents less than half of the PRDA spent fuel inventory.

Two additional cases were considered for the thermal analysis of the universal canister concept (Ref, 5-1). The first reexamined Case 6 of Table 5.4-1 but with the canisters in a concrete storage cask with argon as the fill gas. It was found that the maximum fuel cladding temperature was $388^{\circ} \mathrm{C}\left(730^{\circ} \mathrm{F}\right)$, which is close to the allowable value of $375^{\circ} \mathrm{C}$. This compared to $230^{\circ} \mathrm{C}\left(447^{\circ} \mathrm{F}\right)$ in the "transportation mode," with a steel cask and helium fill gas. 
The second case considered Case 6 (in the transportation mode) with intact rather than consolidated fuel assemblies. The maximum cladding temperature for this situation was $267^{\circ} \mathrm{C}\left(512^{\circ} \mathrm{F}\right)$. Note that this is higher than for consolidated assemblies even though the total heat generation rate is only half.

Table 5.4-1 shows the results of this analysis.

In summary, the results shown in Table 5.4-1 indicate that either canister design can operate in a transport cask and ensure that the maximum fuel cladding temperatures do not exceed the $375^{\circ} \mathrm{C}$ allowable value.

\subsubsection{Criticality Analysis}

A detailed criticality analysis was carried out on the principal canister design which can contain three PWR or six BWR intact spent fuel assemblies. The controlling conditions for this canister design as far as criticality is concerned occurs when six canisters loaded with intact fuel assemblies are placed in a rail cask for shipment and the pool water has not yet been removed from inside the canisters or from between the canisters in the shipping cask. Other conditions which are possible during handling, shipping, and storage operations of the spent fuel were compared to the controlling condition described above to ensure that they represent less severe cases from a criticality standpoint.

The PRDA program spent fuel inventory may be characterized by three primary parameters: fuel type (PWR/BWR), initial fuel enrichment (\% of U-235), and burnup. Previous criticality analyses, like the study described in Ref. 5-3, have shown that a cask containing PWR fuel assemblies is more reactive than when it is carrying BWR fuel assemblies. For that reason, the criticality analysis conducted for this study considers only PWR assemblies. In addition, to make the analysis more conservative, the analysis considered the shipment of fresh fuel only. In 
other words, the upper enrichment limit was evaluated such that the spent fuel may be shipped without the need to take credit for burnup.

Figure 5.1-7 (Section 5.1.3.2) illustrates the physical layout of six truck canisters loaded in a 100-ton cask for transport by rail. The details of the criticality analysis performed are contained in section C. 2 of Appendix $C$ to this report. The results of this analysis are shown in Fig. 5.4-1 which plots the relationship found between the initial enrichment of the fuel to be transported and the multiplication factor $\left(k_{\text {eff }}\right)$ of that fuel in the geometry assumed. Figure 5.4-1 shows that the calculated multiplication factor is below the design basis limit of 0.92 as long as the fuel enrichment level is kept below $3.78 \%$ U-235. The truck canister system, in'either truck cask or rail cask transport mode, is therefore capable of handling the range of PRDA fuel inventory expected because the design basis initial enrichment level spectified is $3.75 \% \mathrm{U}-235$.

Inspection of the large rail canister design (19 PWR/44 BWR intact fuel assembly capacity) reveals that it is a less severe case for criticality concerns than the truck canister case described above.

\subsubsection{Shielding Analysis}

The cask/canister designs proposed for the PRDA study were analyzed to determine the shielding required by these units to allow them to carry the design basis spent fuel within regulatory limits. Both gamma and neutron dose rates were analyzed and minimum shielding thicknesses for each were established. The designs in this study use a combination of steel and depleted uranium for shielding from gamma radiation, while neutron shielding is provided by borosilicone, a solid material having a high hydrogen content and one weight-percent of boron for capturing thermal neutrons and reducing capture gamma radiation. 


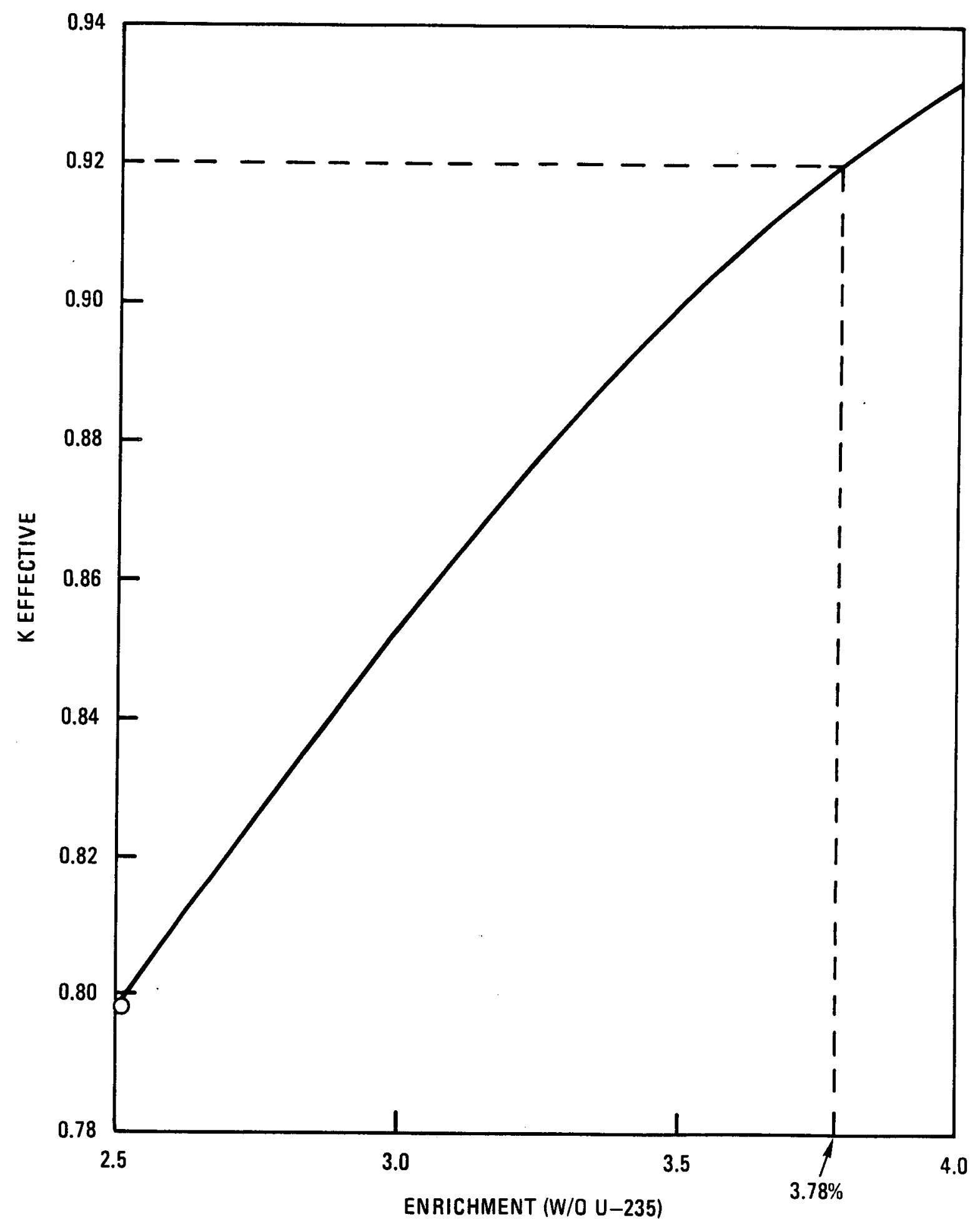

Fig. 5.4-1. Multiplication factor $\left(K_{e f f}\right)$ versus enrichment 
For shielding analysis purposes, the spent fuel to be handled by the cask/canister combinations may be characterized by two primary parameters: (1) fuel burnup and (2) cooling time. On a per metric ton of Initial heavy metal (MTIHM) basis, there is very little difference in the radiation source terms produced in a PWR or a BWR fuel assembly if the fuel burnup and cooling time are the same. Since the burnup of the PWR assemblies is generally higher than that for the BWR assemblies, only the PWR assemblies were analyzed for this study. Results of this analysis should also be applicable to the shipment of BWR assemblies having the same burnup and cooling time.

The design-basis spent fuel for this analysis has a burnup value of 40,000 MWd/MTU and a cooling time of seven years out-of-reactor. The focus of the analysis was on the rall transport cask carrying six principal design canisters. This configuration is illustrated in Fig. 5.1-7 (Section 5.1.3.2). Each of the six canisters is assumed to contain consolidated fuel rods from six PWR fuel assemblies. This results in a total capacity for the rail cask of 36 equivalent spent fuel assemblies. The rail cask with six principal design canisters holding 36 equivalent spent fuel assemblies is felt to be at least as severe for shielding as the case where one alternate design canister holds 38 equivalent assemblies because (1) the extra fuel in the large canister is in the middle where maximum advantage can be taken of self-shielding and (2) the wall of the large canister is thicker than the wall of the small canister, resulting in less of a shielding need for the cask.

Figure 5.4-2 shows a sketch of the rail cask cross section which illustrates the arrangement of $\mathrm{DU}$, steel, and borosilicone shielding materials. The shielding thicknesses were designed to meet the DOT dose rate limits specified in 49CFR173. These 1 imits include $200 \mathrm{mrem} / \mathrm{h}$ at the cask surface and $10 \mathrm{mrem} / \mathrm{h}$ at $2 \mathrm{~m}$ from the side of the transporting vehicle. In the analysis conducted, a design margin of $50 \%$ was assumed (i.e., the calculated total dose rate was multiplied by 1.5 prior to comparison with the allowable limit). 


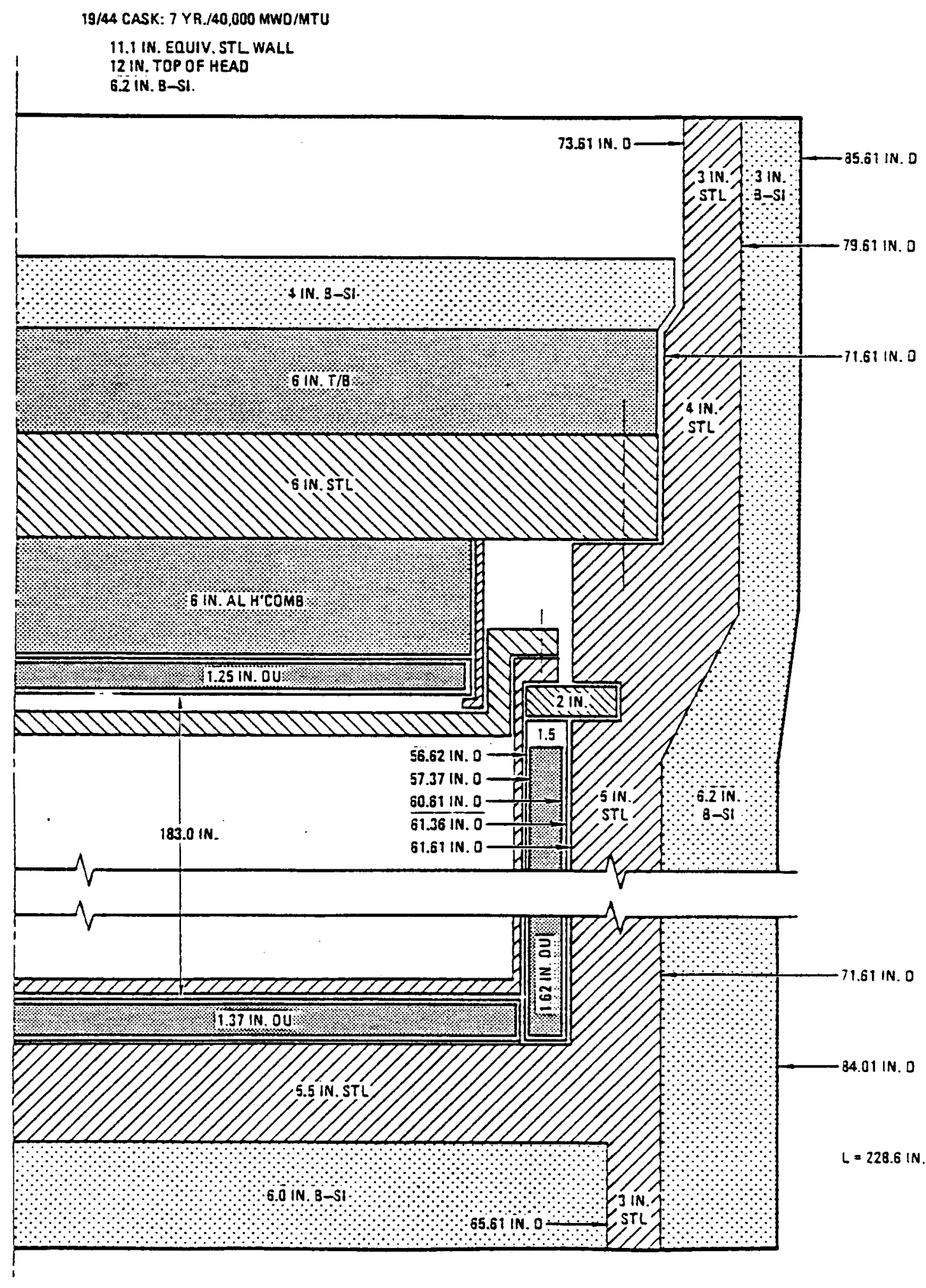

Fig. 5.4-2. Cross section of rail shipping cask 
Detalls of the shielding analysis are contained in Appendix C. 3 to this report. The results of this analysis are summarized below:

Gamma Shielding
(equivalent inches
of stainless steel)

Rail cask

Truck cask
11.1

10.7

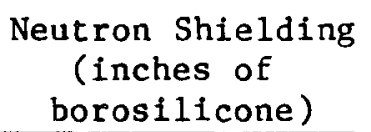

Neutron Shielding

(inches of

borosilicone)

6.2

6.0

These shielding thicknesses are reflected in the cask designs described in Section 5.1. For those cask designs, 1 in. of depleted uranium is assumed to be equivalent to $3 \mathrm{in}$. of stainless steel. The thicknesses listed above are sufficient to meet the DOT limits (with a $50 \%$ margin) assuming that seven-year-old 40,000 MWd/MTU burnup spent fuel is handled. as consolidated rods. This cask system is judged to be capable of handling more than $95 \%$ of the PRDA spent fuel inventory.

\subsubsection{Structural Analysis}

The principal canister design in this study is the canister with a three PWR/six BWR intact fuel assembly capacity which is capable of being transported by truck cask (singly) or by rail cask (six at a time). This canister was examined for the structural loads which it must withstand while performing its function during transportation, storage, or processing missions. The alternate canister design (the rail canister capable of handling 19 PWR or 44 BWR intact fuel assemblies) was not evaluated structurally for this study. Because of the much heavier weight of the rail canister when fully loaded with spent fuel, the structural requirements would be much harder to meet for this canister than for the smaller, principal design canister. It is felt, however, that these requirements could be achieved with the correct selection of materials and structural component sizes.

Because the functions of the canisters designed for this study do not require them to qualify as Type $A$ or $B$ transport packages as defined 
in NRC Regulation 10CFR71 or DOT Regulation 49CFR173, the structural analysis done was relatively basic. Containment during transportation is provided by the truck or rail transport cask, which must meet the requirements specified in those regulations for surviving the hypothetical accident conditions, maintaining the required degree of containment, and providing the required level of shielding, etc. It was decided to measure the principal canister design against the requirements stated in those regulations for lifting packages between transport or storage casks and processing or storage facilities. Those regulations require that lifting devices on packages be capable of supporting three times the weight of the loaded package without generating stresses in excess of their yield strength.

The canister design shown in Figs. 5.1-1 and 5.1-2 was analyzed in the following areas:

1. Weight - empty and fully loaded.

2. Canister 1id locking cams (seven).

3. Canister lid locking cam pins (seven).

4. Butt welds fastening the locking cam pins to the canister lid.

5. Canister wall groove where locking cams are fastened.

6. Canister 11d.

7. Butt weld fastening the pickup ring to the canister lid.

As a result of the analysis done, the following areas were modified from the inftial canister design:

1. Stiffening ribs were added to the canister bottom and a skirt was added at the bottom of the canister walls to help absorb normal jolts during loading and unloading activities.

2. The thickness of the seven canister 11d locking cams was increased from $0.25 \mathrm{in}$. to $0.375 \mathrm{in}$. 
3. The size of the seven locking cam pins was increased from $0.375 \mathrm{in.} \mathrm{to} 0.625 \mathrm{in}$.

4. The size of the butt welds fastening the locking cam pins to the canister lid was specified at 0.188 in.

5. The canister lid was increased in thickness from 0.5 in. to $1.0 \mathrm{in}$.

6. The size of the butt weld which fastens the pickup ring to the canister lid was specified at 0.188 in.

All of the areas examined qualify structurally using either carbon steel or stainless steel materials. No major obstacles were encountered during the structural analysis which would make it impossible for the princlpal canister design to meet all structural regulatory requirements.

Further details of the structural analysis performed are contained in Appendix C.4.

\subsection{COST ESTIMATES}

Costs were estimated for components used in this study which differ from the DOE reference system. The major components fitting into that category are listed as follows:

1. Truck canister ("principal" canister design).

2. Rail canister ("alternate" canister design).

3. Truck transport cask.

4. Rall transport cask.

5. At-reactor storage cask. 
This section presents a summary of the costs estimated for these components. Details of these estimates are contained in Appendix D.1. A description of these components is contained in Section 5.

The costs contained in this section are used as input to the economic evaluation code (WADCOM), which compares the combinations of equipment and facilities defined for each case on a cost basis. This procedure is discussed in Section 6. In addition to containing the details of the cost estimates made for the five components listed above, Appendix D.1 also contains the details of other costs modified in the basic WADCOM program as a result of using components or facilities which differ from the DOE reference system.

\subsubsection{General Cost Assumptions}

1. Costs are presented in January 1985 dollars.

2. Costs are presented on a per-component basis for both firstof -a-kind and equilibrium units.

3. Manufacturer's markup for labor and material used within the estimates represents the expected pricing from a medium-tolarge supplier.

4. Material unit costs are based on dollars-per-pound quotations and estimates for similar components.

\subsubsection{Cost Estimates}

5.5.2.1. Principal Canister Design. Table 5.5-1 summarizes the costs estimated for the 3 PWR/ 6 BWR intact fuel assembly capacity canister for both carbon steel and stainless steel materials of construction. The cost estimates assume a quantity discount on material of $5 \%$ after the first 500 units and an additional 5\% after the first 8000 units. 
TABLE $5.5-1$

PRINCIPAL CANISTER DESIGN COST SUMMARY

\begin{tabular}{|c|c|c|c|c|}
\hline & $\begin{array}{l}\text { Material } \\
(\$)\end{array}$ & & $\begin{array}{c}\text { Labor }^{(a)} \\
(\$)\end{array}$ & $\begin{array}{c}\text { Total } \\
(\$)\end{array}$ \\
\hline \multicolumn{5}{|l|}{ Carbon stee ${ }^{(b)}$} \\
\hline First unit & 2,303 & & 15,092 & 17,395 \\
\hline 8200 th unit & 2,073 & & 3,836 & 5,909 \\
\hline Average for 8200 units & 2,195 & & 4,795 & 6,990 \\
\hline Equivalent $\$ / 1 b$ & $\begin{array}{l}\text { First unit } \\
8200 \text { th unit } \\
\text { Average for } 8200\end{array}$ & $\begin{array}{r}13.40 \\
4.55 \\
5.40\end{array}$ & & \\
\hline \multicolumn{5}{|l|}{ Stainless steel ${ }^{(c)}$} \\
\hline First unit & 4,045 & & 21,098 & 25,143 \\
\hline 8200 th unit & 3,640 & & 5,360 & 9,405 \\
\hline Average for 8200 units & 3,855 & & 6,895 & 10,750 \\
\hline Equivalent $\$ / 1 b$ & $\begin{array}{l}\text { First unit } \\
8200 \text { th unit } \\
\text { Average for } 8200\end{array}$ & $\begin{array}{r}19.30 \\
7.25 \\
8.25\end{array}$ & & \\
\hline
\end{tabular}

(a) Assumes 90\% learning curve.

(b) See Table D-4 (Appendix D.1) for details.

${ }^{(c)}$ See Table D-6 (Appendix D.1) for details. 
A 90\% learning curve is applied to the labor portion of the estimate. Table D-4, in Appendix D.1, illustrates the effects of learning and material discounts as the number of carbon steel canisters produced is varied. Table D-6 (Appendix D.1), illustrates the same effects for stainless steel canisters.

The cost estimates are based on sufficient detail to be considered reasonably reliable. In the quantities that would be required, canister slope should not result in higher unit costs since an automated process would be used to easily produce the desired shape in mass production. As new requirements are imposed on the canister, its cost may increase as would other canister developed in the PRDA study.

5.5.2.2. Alternate Canister Design. Table 5.5-2 summarizes the costs estimated for the $19 \mathrm{PWR} / 44$ BWR intact fuel assembly capacity canister for both carbon steel and stainless steel materials of construction. The material discount factors and the learning curve applied are identical to those used for the principal design canister. Details of the cost estimates for this design are contained in Table D (Appendix D.1) for carbon steel material, and in Table D-2 (Appendix D.1) for stainless steel material.

5.5.2.3. Truck Transport Cask. Table 5.5-3 summarizes the costs estimated for fabrication of this cask, which is designed to transport one principal canister design containing intact spent fuel assemblies or consolidated fuel rods. These costs are based on the production of 300 casks, with a 95\% learning curve applied to the labor required for the first 64 units and a $16 \%$ quantity discount applied to the material. Table D-7 (Appendix D.1) contains the details of the cost estimate for fabrication of this cask. The front end design and certification costs for this cask are contained in Table 5.5-4.

5.5.2.4. Rail Transport Cask. Table 5.5-3 also summarizes the costs estimated for fabrication of the rail transport cask, which is designed 
TABLE $5 \cdot 5-2$

ALTERNATE CANISTER DESIGN (RAIL) COST SUMMARY

\begin{tabular}{|c|c|c|c|c|}
\hline & $\begin{array}{c}\text { Material } \\
(\$)\end{array}$ & & $\begin{array}{c}\text { Labor } \\
(\$)\end{array}$ & $\begin{array}{c}\text { Total } \\
(\$)\end{array}$ \\
\hline \multicolumn{5}{|l|}{ Carbon steel ${ }^{(b)}$} \\
\hline First unit & 11,900 & & 12,480 & 24,380 \\
\hline 8200 th unit & 10,710 & & 3,172 & 13,882 \\
\hline Average for 8200 units & 11,340 & & 4,060 & 15,400 \\
\hline Equivalent $\$ / 1 \mathrm{~b}$ & $\begin{array}{l}\text { First unit } \\
8200 \text { th unit } \\
\text { Average for } 8200\end{array}$ & $\begin{array}{l}3.60 \\
2.05 \\
2.25\end{array}$ & & \\
\hline \multicolumn{5}{|l|}{ Stainless steel ${ }^{(c)}$} \\
\hline First unit & 40,870 & & 16,290 & 57,160 \\
\hline 8200 th unit & 36,780 & & 4,140 & 40,920 \\
\hline Average for 8200 units & 38,950 & & 5,300 & 44,250 \\
\hline Equivalent $\$ / 1 b$ & $\begin{array}{l}\text { First unit } \\
8200 \text { th unit } \\
\text { Average for } 8200\end{array}$ & $\begin{array}{l}8.40 \\
6.00 \\
6.50\end{array}$ & & \\
\hline
\end{tabular}
(a) Assumes 90\% learning curve.
(b) See Table D-1 (Appendix D.1) for details.
(c) See Table D-2 (Appendix D.1) for details. 
TABLE 5.5-3

TRANSPORT AND STORAGE CASKS COST SUMMARY

\begin{tabular}{|c|c|c|c|c|}
\hline & \multicolumn{2}{|c|}{$\begin{array}{l}\text { Material } \\
(\$)\end{array}$} & $\begin{array}{l}\text { Labor }^{(a)} \\
(\$)\end{array}$ & $\begin{array}{c}\text { Total } \\
(\$)\end{array}$ \\
\hline \multicolumn{5}{|l|}{ Truck transport cask ${ }^{(b)}$} \\
\hline First unit & \multicolumn{2}{|c|}{981,000} & 33,000 & $1,014,000$ \\
\hline 64 th unit & \multicolumn{2}{|c|}{824,000} & 24,000 & 848,000 \\
\hline Equivalent $\$ / 1 b$ & $\begin{array}{l}\text { First unit } \\
64 \text { th unit }\end{array}$ & $\begin{array}{l}15.85 \\
13.30\end{array}$ & & \\
\hline \multicolumn{5}{|l|}{ Rail transport cask(c) } \\
\hline First unit & \multicolumn{2}{|c|}{$1,881,600$} & 77,500 & $1,959,100$ \\
\hline 16 th unit & \multicolumn{2}{|c|}{$1,787,500$} & 63,200 & $1,850,700$ \\
\hline Equivalent $\$ / 1 b$ & $\begin{array}{l}\text { First unit } \\
16 \text { th unit }\end{array}$ & $\begin{array}{l}13.00 \\
12.30\end{array}$ & & \\
\hline \multicolumn{5}{|l|}{ Storage cask ${ }^{(d)}$} \\
\hline Total cost per cask & & 500,000 & & \\
\hline Equivalent $\$ / 1 b$ & & 3.20 & & \\
\hline
\end{tabular}

(a) Assumes 95\% learning curve for first 64 truck casks and for first 16 rail casks.
(b) See Table D-7 (Appendix D.1) for details.
(c) See Table D-8 (Appendix D.1) for details.
(d) See Table D-9 (Appendix D.1) for details. 
TABLE $5.5-4$

TRANSPORT AND STORAGE CASKS: DESIGN AND CERTIFICATION COSTS $(\$ 000)$

\begin{tabular}{|c|c|c|c|c|}
\hline & \multicolumn{3}{|c|}{$\begin{array}{c}\text { Years Prior to } \\
\text { Cask Need }\end{array}$} & \multirow[b]{2}{*}{ Totals } \\
\hline & 3 & 2 & 1 & \\
\hline \multicolumn{5}{|l|}{ Truck transport cask } \\
\hline Design, analysis, and certification & 925 & 465 & 460 & 1850 \\
\hline Project management & 110 & 105 & 110 & 325 \\
\hline QA & 120 & 235 & 120 & 475 \\
\hline Testing & -- & 375 & 125 & 500 \\
\hline Totals & 1155 & 1180 & 815 & 3150 \\
\hline \multicolumn{5}{|l|}{ Rail transport cask } \\
\hline Design, analysis, and certification & 1200 & 600 & 600 & 2400 \\
\hline Project management & 140 & 140 & 140 & 420 \\
\hline QA & 160 & 315 & 155 & 630 \\
\hline Testing & -- & 500 & 250 & 750 \\
\hline Totals & 1500 & 1555 & 1145 & 4200 \\
\hline \multicolumn{5}{|l|}{ Storage cask } \\
\hline Design, analysis, and certification & 850 & 425 & 425 & 1700 \\
\hline Project management & 90 & 90 & 90 & 270 \\
\hline QA & 95 & 190 & 95 & 380 \\
\hline Testing & - & 150 & 50 & 200 \\
\hline Totals & 1035 & 855 & 660 & 2550 \\
\hline
\end{tabular}


to handle six loaded principal design canisters or one loaded alternate design canister. These costs are based on the production of 50 casks, with a 95\% learning curve applied to the labor required for the first 16 units and a $5 \%$ quantity discount applied to the material. Table D-8 (Appendix D.1) contains further detalls of this cost estimate. The front end design and certification costs estimated for this cask are contained in Table 5.5-4.

5.5.2.5. At-Reactor Storage Cask. The cost estimate for this cask is based on the work performed and reported upon in Ref. 5-2. This cask is a cast iron design with the capacity to store six principal design canisters or one alternate design canister. The cost estimate performed in Ref. 5-4 has been modified to account for minor design changes to accommodate the current canister designs and to adjust for escalation since the initial estimate. Table 5.5-3 contains the current estimate for fabrication of this cask. The details behind this estimate are contained in Table D-9 in Appendix D.1. The front end design and certification costs estimated for this cask are contained in Table 5.5-4.

\subsection{REFERENCES}

5-1. Title 49, Code of Federal Regulations, Part 173, "Shippers General Requirements for Shipments and Packagings."

5-2. Schneringer, P. E., and P. G. K. Doroszlai, "MODREX Application Study to Support the Sequoyah Nuclear Power Plant," GA Report GA-A16673, March 1982.

5-3. Viebrook, J. M., M. J. Blackwood, et al., "Alternatives for Water Basin Spent Fue1 Storage Generic Issues," SRO-1051-5, NAC-C-7919 Part V, Nuclear Assurance Corporation, September 1979. 


\section{SYSTEM ECONOMICS}

The reference waste management system and a system with an integrated MRS were evaluated to determine the economic impact of using the universal canister. The PRDA reference system, which was modeled with the WADCOM-MF computer program by Roy F. Weston, Inc. (Refs. 6-1 and 6-2), formed the basis for the evaluation of the GA systems. From this basis, cases were formulated to evaluate both the reference and integrated MRS systems with the GA alternative concepts. The six cases reported assume on-time repository startup. Three reference and three integrated MRS cases were run, one for each repository pair: salt/ granite, tuff/granite, and basalt/granite.

\subsection{WADCOM-MF INPUT ASSUMPTIONS}

The major differences between the PRDA reference case and the GA cases are summarized in Table 6.1-1. A more detail breakdown of these difference is provided in Appendix D.1. The following is a summary of the assumptions which were made to evaluate the GA concepts.

6.1.1. Dry At-Reactor Storage (DRS)

The PRDA reference operating costs were used except for the storage cask which was assumed to be the GA design described in Section 5. The cost of the six canisters in each cask was included in the DRS storage cask cost for the reference system cases but in the MRS costs in the integrated MRS cases. This was necessary to properly account for the correct number of canisters. 
TABLE $6 \cdot 1-1$

MAJOR DIFFERENCES: GA CASES VERSUS PRDA REFERENCE CASE

\begin{tabular}{|c|c|c|}
\hline & $\begin{array}{c}\text { PRDA } \\
\text { Reference Case }\end{array}$ & $\begin{array}{l}\text { GA } \\
\text { Cases }\end{array}$ \\
\hline $\begin{array}{l}\text { At-reactor storage } \\
\text { Cask capacity, MTU } \\
\text { Cask cost, milition } 85 \$\end{array}$ & $\begin{array}{c}11.09^{(a)} \\
1.0\end{array}$ & $\begin{array}{l}8.30^{(a)} \\
0.544^{(b)}\end{array}$ \\
\hline $\begin{array}{l}\text { Truck transport cask } \\
\text { Cask capacity, PWRR SFAs } \\
\text { Cask cost, million } 85 \$\end{array}$ & $\begin{array}{l}1 \text { or } 2^{(c)} \\
1.2\end{array}$ & $0.85^{(d)}$ \\
\hline $\begin{array}{l}\text { Rail transport cask } \\
\text { Cask capacity, PWR SFAs } \\
\text { Cask cost, milition } 85 \$\end{array}$ & 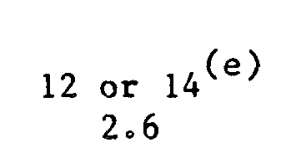 & $1.85^{(d)}$ \\
\hline $\begin{array}{l}\text { Spent fuel canister } \\
\text { Capacity, PWR SFAs } \\
\text { Cost, } \$ M\end{array}$ & $\begin{array}{l}\text { (f) } \\
\text { (f) }\end{array}$ & $0.006^{(\mathrm{g})}$ \\
\hline $\begin{array}{l}\text { MRS facility } \\
\text { Repositories (integrated MRS system) } \\
\text { Waste package o.d. }(\mathrm{cm})\end{array}$ & (h) & (i) \\
\hline $\begin{array}{l}\text { Salt } \\
\text { Tuff, granite } \\
\text { Basalt }\end{array}$ & $\begin{array}{l}84.5 \\
70.1 \\
89.0\end{array}$ & $\begin{array}{l}84.5 \\
70.1 \\
110.5\end{array}$ \\
\hline $\begin{array}{l}\text { Waste package capacity (equivalent PWR SFAs) } \\
\text { Salt } \\
\text { Tuff, granite } \\
\text { Basalt }\end{array}$ & $\begin{array}{r}12 \\
6 \\
4\end{array}$ & $\begin{array}{l}8^{(k)} \\
6 \\
4\end{array}$ \\
\hline
\end{tabular}

(a) Assumes intact PWR SFAs at $0.461 \mathrm{MTU} / \mathrm{SFA}$.

(b) Includes fabrication cost for one cask and six spent fuel canister. Cask design and certification costs are handled separately in the economic analysis.

(c) Derated to 1 SFA if spent fuel is less than 10 years old.

(d) Plus cask design and certification costs which are handled separately in the economic analysis.

(e) Derated to 12 SFAs if spent fuel is less than 10 years old.

(f) PRDA reference case does not include canisters.

(g) Cost of canisters varies with quantity procured. $\$ 6000$ is representative cost per canister for the cases examined. 
(h) No MRS is included in the PRDA reference case.

(i) Detailed explanation of MRS facility costs and capacities given in Table D-10 (Appendix D).

(j) The GA canister used as part of the emplacement package fits within the PRDA reference package diameters for all repository media except basalt. For a basalt repository, the larger size of the GA canister (compared to the reference package for basalt) increases the o.d. of the burial package.

(k) same waste capacity as the PRDA reference packages for all repository media except salt. The waste capacity for a salt repository is 1 imited by the volume of the GA canister. Package spacing is adjusted according $1 y$. 
6.1.2. Transportation

The $30 \%$ truck and $70 \%$ rail split is assumed for all shipments originating from reactors and $100 \%$ rail for all MRS shipments. The WADCOM-MF input was modified, as required, to include the GA truck and rail cask designs described in Section 5. The truck cask requires overweight shipment, and the speed input was reduced from 35 to $25 \mathrm{mph}$. The GA designs did not require derating, as was done in the reference case, for under 10-year-old fuel.

\subsubsection{Fuel Consolidation}

Since WADCOM-MF does not model fuel consolidation at the MRS, these costs were calculated separately using an electronic spreadsheet for the integrated MRS system. The calculations are based on the at-repository consolidation module in WADCOM-MF. Since these costs are incremental, they were added back into the summary and cash flow tables.

\subsubsection{Integrated MRS}

Costs for the integrated MRS facility were not included in the PRDA assumptions (Ref. 1-1): The MRS costs presented in this report were generated from preliminary cost information provided at the beginning of the PRDA studies. In addition, the MRS configuration costed in this study assumed that all prepackaging of the spent fuel (consolidation, canisterization and final overpacking) would be performed at the MRS; i.e., a fully loaded MRS facility was costed. Therefore, actual MRS facility costs could vary considerably from the presented costs, depending on the final MRS facility configuration and on updated cost information. Receiving and handling facility costs were assumed to be those estimated by Kaiser Engineers and GA in 1983 (Refs. 6-3 and 6-4) and escalated to 1985. This facility was designed to receive and consolidate fuel rods into canisters. Concrete storage cask costs $(\$ 140,000$ each) were based on preliminary estimates provided by PNL in a personal 
communication. Waste package costs calculated by WADCOM-MF were assumed to occur at the repository. Appendix D.l provides the detail MRS cost breakdown.

\subsubsection{Repositories}

For the reference case, the receiving facility capital costs were decreased to reflect fewer truck shipments using the OWT casks and the higher capacity rail casks.

As shown in Table 6.1-1, the repository waste package was impacted in the integrated MRS case. In the case of the salt repository, the package spacing was reduced in proportion to the reduction in heat load due to 8 versus 12 equivalent PWR spent fuel assemblies. For the basalt repository, the emplacement hole diameter was increased to accommodate the larger package. Credit was taken in the salt and tuff repository to account for replacing the internal basket in the waste package with the universal canister.

\subsection{RESULTS OF ECONOMIC ANALYSIS}

Table 6.2-1 presents total undiscounted costs for each GA waste management system. The PRDA reference system is included for comparison. The total CRWM system costs are also broken down by major element. Table 6.2-2 shows the cost savings of both GA systems when compared to the PRDA reference system. The comparison of the integrated MRS against the PRDA reference system does not reflect the impact of the universal canister which can only be seen if compared against other integrated MRS systems.

\subsubsection{Comparison of PRDA Reference System to GA Reference System}

Cost savings in the CRWM realized by the GA reference system are primarily attributable to the transportation costs. Utilizing the GA 
TABLE $6.2-1$

RADIOACTIVE WASTE MANAGEMENT SYSTEM COSTS

(Mil11on 1985 Dollars Undiscounted)

\begin{tabular}{|c|c|c|c|c|c|c|}
\hline & DRS & CRWM & Transportation & Repository 1 & Repository 2 & MRS \\
\hline \multicolumn{7}{|l|}{ PRDA reference $(a)$} \\
\hline Tuff/granite & 713 & 14,393 & 1,856 & 7,007 & 5,531 & N/A \\
\hline Salt/granite & 713 & 13,747 & 1,491 & 6,725 & 5,531 & N/A \\
\hline Basalt/granite & 713 & 18,300 & 1,929 & 10,840 & 5,531 & $\mathrm{~N} / \mathrm{A}$ \\
\hline \multicolumn{7}{|l|}{ GA reference } \\
\hline Tuff/granite & 551 & 13,613 & 1,080 & 7,004 & 5,528 & $\mathrm{~N} / \mathrm{A}$ \\
\hline Salt/granite & 551 & 13,109 & 857 & 6,723 & 5,528 & $\mathrm{~N} / \mathrm{A}$ \\
\hline Basalt/granite & 551 & 17,491 & 1,125 & 10,838 & 5,528 & $\mathbf{N} / \mathbf{A}$ \\
\hline \multicolumn{7}{|l|}{ GA integrated MRS } \\
\hline Tuff./granite & 193 & 15,975 & 1,296 & 6,832 & 5,378 & 2,470 \\
\hline Salt/granite & 193 & 15,890 & 1,157 & 6,951 & 5,378 & 2,404 \\
\hline Basalt/grarite & 193 & 20,359 & 1,309 & 11,110 & 5,378 & 2,562 \\
\hline
\end{tabular}

(a)From Ref. 6-2. 
TABLE $6.2-2$

COST SAVINGS FROM GA SYSTEMS

(Million 1985 Dollars Undiscounted)

\begin{tabular}{|c|c|c|c|c|c|c|}
\hline & DRS & CRWM & Transportation & Repository 1 & Repository 2 & MRS \\
\hline \multicolumn{7}{|c|}{ PRDA reference versus GA reference } \\
\hline Tuff/granite & 162 & 781 & 776 & 2 & 2 & N/A \\
\hline Salt/granite & 162 & 638 & 634 & 2 & 2 & N/A \\
\hline Basalt/granite & 162 & 800 & 804 & 2 & 2 & N/A \\
\hline \multicolumn{7}{|c|}{ GA reference versus GA integrated MRS } \\
\hline Tuff/granite & 358 & -2363 & -215 & 172 & 150 & -2468 \\
\hline Salt/granite & 358 & -2781 & -300 & -228 & 150 & -2404 \\
\hline Basalt/granite & 358 & -2868 & -184 & -272 & 150 & -2562 \\
\hline \multicolumn{7}{|c|}{ PRDA reference versus GA integrated MRS } \\
\hline Tuff/granite & 520 & -1582 & 560 & 174 & 153 & -2470 \\
\hline Salt/granite & 520 & -2143 & 333 & -226 & 153 & -2404 \\
\hline Basalt/granite & 520 & -2059 & 620 & -270 & 153 & -2562 \\
\hline
\end{tabular}


design overweight truck cask and rail cask for shipment of the spent fuel results in a reduction of 630 to 800 million dollars, depending on the repository geology combination. Because of the shape of the canister as discussed in Section 5, the GA system carries a larger payload. Also because the system can handle higher burnup fuel it does not require derating if fuel age drops below 10 years.

The effect of reducing the capital construction costs for the receiving facility at the repositories, (Section 6.1 ) accounts for a 4.5 to 4.8 million dollar cost savings.

A cost savings of 162 million dollars is realized with the GA concept for at-reactor dry storage.

\subsubsection{Comparing the GA Reference System with the GA Integrated MRS System}

Cost savings of 360 million dollars are realized in the DRS costs because the integrated MRS System begins accepting fuel 2 years earlier than the reference system. The resulting inventory in the DRS is much lower: $7300 \mathrm{MTU}$ for the reference system and 2900 MTU for the integrated MRS system. The DRS inventory is reduced approximately $60 \%$ from the reference system, resulting fewer storage casks needed. The DRS costs reflect a $65 \%$ reduction for the integrated system over the reference system. The additional $5 \%$ reduction in cost may be attributed in part to the fact that in the reference system the canister costs are associated with the DRS, and when an MRS is in the system canister costs are included with the MRS.

The cost savings of 150 million dollars shown for repository 2 , the granite geology, is explained by the credit taken in the waste package cost, as discussed in Section 6.1. This credit is taken when an MRS is in the sy tem because canistered consolidated spent fuel is received at the repository, negating the need of an internal basket, and accounts for about $50 \%$ of the 150 million. The other $50 \%$ can be attributed to 
the incremental consolidation costs which are transferred from the repository to the MRS cost element. See, for example, Table 6.2-6 and 6.2-9, repository breakdown.

For repository 1, the basalt geology, the GA integrated MRS system is seen to have a cost increase of 270 million dollars over the GA reference system. The cost savings incurred because of the change in locale of consolidation is offset by the increase in the waste package cost due to increased waste package diameter and the fact that the reduction in capttal of the receiving facility taken in the reference system is not taken in the integrated MRS system. This factor is common to all repository geologies although its contribution is observedly sma11.

For repository 1, the salt geology, the integrated MRS system increases the costs by 225 million dollars. The saving incurred by taking a credit on the waste package cost and removal of the consolidation costs is offset by increases accrued due to reducing the number of spent fuel assemblies per repository package (more packages and more holes needed in the integrated MRS system).

For repository 1, the tuff geology, the integrated MRS system rea1ized a savings of 174 million dollars attributable to the credit taken on the waste package cost and removal of the costs of consolidation.

Transportation costs are observed to increase when an MRS is in the system. the Integrated MRS system has two transportation links, reactor to MRS and MRS to repository, whereas the reference system has only one, reactor to repository. The increases range from 180 to 300 million dollars depending on the repository geology combination and are related to the respective distances which in turn affect the transportation costs.

The integrated MRS system costs are shown as increases over the reference system. They are made up of the MRS facility costs and the 
consolidation costs. These cost increases contribute the major portion of the cost increase seen for the total CRWM integrated system over the reference system. Of these costs 150 to 220 million can be attributed to the cost of concrete storage cask required to store the 21,300 MTU of spent fuel due to early MRS startup.

\subsubsection{Comparison of the PRDA Reference System with the GA Alternate System}

It is readily apparent that with regard to the repositories, the MRS, and the DRS, the comments of the previous subsection comparing the GA reference system with the GA integrated system apply, although the numerical quantities differ.

The significant variable introduced here is the transportation element. Cost savings in transportion due to GA cask/canister concepts outweigh the cost increase due to the additional transportation link in the integrated MRS system. The savings range from 330 to 620 million dollars, depending on the repository geology combination.

Summary tables for each geology are given in Tables 6.2-3 through 6.2-11. The PRDA reference case summary was provided by Weston Consu1tants (Ref. 6-3). These tables show the second level breakdown of each system cost element. Transportation is indicated for each appropriate link; the repository is divided into waste packaging, repository system (mine), and consolidation (in the reference systems). The MRS is divided into the facility and incremental consolidation costs, and DRS is indicated as a separate line item, since these costs are not part of the CRWM program.

\subsection{DISCOUNTED CASH FLOWS}

Comparison of the top level discounted and undiscounted dollars is shown in Table 6.3-1. All dollars are in millions and were discounted back to 1985 at a rate of $3 \%$ per annum. Costs for the CRWM system for 
TABLE $6.2-3$

PRDA REFERENCE SYSTEM BASALT X GRANITE

\begin{tabular}{lrrrr}
\hline & Capital & Operating & Decommissioning & \multicolumn{1}{c}{ Total } \\
\hline $\begin{array}{l}\text { DRS } \\
\text { Transportation }\end{array}$ & & 713.04 & & 713.04 \\
$\quad \begin{array}{l}\text { Truck } \\
\text { Rail }\end{array}$ & 89.70 & 746.25 & & 835.95 \\
Repository 1 & 227.50 & 865.62 & & $1,093.12$ \\
$\quad$ Consolidation & 57.00 & 17.64 & 9.00 & 83.64 \\
Waste package & 323.23 & $1,452.59$ & 52.04 & $1,827.86$ \\
Repository & $1,756.82$ & $7,090.23$ & 81.25 & $8,928.3$ \\
Repository 2 & & & & 79.23 \\
Consolidation & 57.00 & 13.23 & 9.00 & $1,420.61$ \\
Waste package & 207.51 & $1,179.69$ & 33.41 & $4,030.81$ \\
Repository & 590.26 & $3,398.59$ & 41.96 & \\
Totals & & & & \\
System & $18,299.52$ & & & \\
DRS & 713.04 & & & \\
\hline
\end{tabular}


TABLE $6.2-4$

PRDA REFERENCE SYSTEM SALT X GRANITE

\begin{tabular}{lrrrr}
\hline & Capital & Operating & Decommissioning & Total \\
\hline $\begin{array}{l}\text { DRS } \\
\text { Transportation }\end{array}$ & & 713.04 & & 713.04 \\
$\quad$ Truck & 69.00 & 533.58 & & 602.58 \\
Rail & 195.30 & 692.93 & & 888.23 \\
Repository 1 & 57.00 & 17.64 & 9.00 & 83.64 \\
Consolidation & 314.03 & $1,110.48$ & 50.56 & $1,475.07$ \\
$\begin{array}{l}\text { Waste package } \\
\text { Repositiory }\end{array}$ & $1,237.88$ & $3,736.75$ & 191.93 & $5,166.56$ \\
Repository 2 & & & & 79.23 \\
Consolidation & 57.00 & 13.23 & 9.00 & $1,420.61$ \\
Waste package & 207.51 & $1,179.69$ & 33.41 & $4,030.85$ \\
Repository & 590.26 & $3,398.63$ & 41.96 & \\
Totals & & & & \\
System & $13,746.77$ & & & \\
DRS & 713.04 & & & \\
\hline
\end{tabular}


TABLE $6.2-5$

PRDA REFERENCE SYSTEM TUFF X GRANITE

\begin{tabular}{lrrrr}
\hline & Capital & Operating & Decommissioning & Total \\
\hline $\begin{array}{l}\text { DRS } \\
\text { Transportation }\end{array}$ & & 713.04 & & 713.04 \\
$\quad \begin{array}{l}\text { Truck } \\
\text { Rail }\end{array}$ & 82.80 & 699.21 & & 782.01 \\
Repository 1 & 225.40 & 848.61 & & $1,074.01$ \\
Consolidation & 57.00 & 17.64 & 9.00 & 83.64 \\
Waste package & 286.89 & $1,520.82$ & 46.19 & $1,853.9$ \\
$\quad$ Repositiory & 722.80 & $4,277.95$ & 68.3 & $5,069.05$ \\
Repository 2 & & & 9.00 & 79.23 \\
Consolidation & 57.00 & 13.23 & 33.41 & $1,420.61$ \\
Waste package & 207.51 & $1,179.69$ & 41.96 & $4,030.85$ \\
Repository & 590.26 & $3,398.63$ & & \\
Totals & & & & \\
System & $14,393.30$ & & & \\
DRS & 713.04 & & & \\
\hline
\end{tabular}


TABLE $6.2-6$

GA REFERENCE SYSTEM BASALT X GRANITE

\begin{tabular}{|c|c|c|c|c|}
\hline & Capital & Operating & Decommissioning & Total \\
\hline DRS & 2.55 & 548.17 & & 550.72 \\
\hline \multicolumn{5}{|l|}{ Transportation } \\
\hline Truck & 37.10 & 398.31 & & 435.41 \\
\hline Rail & 123.53 & 566.5 & & 690.03 \\
\hline \multicolumn{5}{|l|}{ Repository 1} \\
\hline Consolidation & 57.00 & 17.64 & 9.00 & 83.64 \\
\hline Waste package & 323.23 & $1,452.63$ & 52.04 & $1,827.90$ \\
\hline Repository & $1,754.52$ & $7,090.13$ & 81.21 & $8,925.86$ \\
\hline \multicolumn{5}{|l|}{ Repoistory 2} \\
\hline Consolidation & 57.00 & 13.23 & 9.00 & 79.23 \\
\hline Waste package & 207.51 & $1,179.64$ & 33.41 & $1,420.56$ \\
\hline Repository & 587.93 & $3,398.59$ & 41.90 & $4,028.42$ \\
\hline \multicolumn{5}{|l|}{ Totals } \\
\hline System & $17,491.05$ & & & \\
\hline DRS & 550.72 & & & \\
\hline
\end{tabular}


TABLE $6.2-7$

GA REFERENCE SYSTEM SALT X GRANITE

\begin{tabular}{lrrrr}
\hline & Capital & Operating & Decommissioning & Total \\
\hline $\begin{array}{l}\text { DRS } \\
\text { Transportation }\end{array}$ & 2.55 & 548.17 & & 550.72 \\
$\begin{array}{l}\text { Truck } \\
\text { Rail }\end{array}$ & 27.37 & 276.75 & & 304.12 \\
Repository 1 & 102.38 & 450.75 & & 553.12 \\
$\begin{array}{l}\text { Consolidation } \\
\text { Waste package }\end{array}$ & 314.03 & $1,110.48$ & 50.56 & $1,475.07$ \\
Repository & $1,235.67$ & $3,736.75$ & 191.72 & $5,164.14$ \\
Repository 2 & & & & 79.23 \\
Consolidation & 57.00 & 13.23 & 9.00 & $1,421.20$ \\
Waste package & 207.51 & $1,179.69$ & 34.00 & $4,028.42$ \\
Repository & 587.93 & $3,398.59$ & 41.90 & \\
Totals & & & & \\
System & $13,108.95$ & & & \\
DRS & 550.72 & & & \\
\hline
\end{tabular}


TABLE $6.2-8$

GA REFERENCE SYSTEM TUFF X GRANITE

\begin{tabular}{|c|c|c|c|c|}
\hline & Capital & Operating & Decommissioning & Total \\
\hline DRS & 2.55 & 548.17 & & 550.72 \\
\hline \multicolumn{5}{|l|}{ Transportation } \\
\hline Truck & 34.63 & 369.03 & & 403.66 \\
\hline Ra11 & 121.37 & 555.17 & & 676.54 \\
\hline \multicolumn{5}{|l|}{ Repository 1} \\
\hline Consolidation & 57.00 & 17.64 & 9.00 & 83.64 \\
\hline Waste package & 286.89 & $1,520.94$ & 46.19 & $1,854.02$ \\
\hline Repository & 720.47 & $4,277.95$ & 68.21 & $5,066.63$ \\
\hline \multicolumn{5}{|l|}{ Repository 2} \\
\hline Consolidation & 57.00 & 13.23 & 9.00 & 79.23 \\
\hline Waste package & 207.51 & $1,179.64$ & 33.41 & $1,420.56$ \\
\hline Repository & 587.93 & $3,398.59$ & 41.90 & $4,028.42$ \\
\hline \multicolumn{5}{|l|}{ Totals } \\
\hline System & $13,612.70$ & & & \\
\hline DRS & 550.72 & & & \\
\hline
\end{tabular}


TABLE 6.2-9

GA INTEGRATED MRS BASALT X GRANITE

\begin{tabular}{|c|c|c|c|c|}
\hline & Capital & Operating & Decommissioning & Total \\
\hline DRS & 2.55 & 190.18 & & 192.73 \\
\hline \multicolumn{5}{|l|}{ Transportation } \\
\hline Truck & 23.22 & 211.52 & & 234.74 \\
\hline Rail RX & 94.09 & 388.24 & & 482.33 \\
\hline Rail MRS & 88.20 & 504.40 & & 592.60 \\
\hline \multicolumn{5}{|l|}{ MRS } \\
\hline Consolidation & 75.72 & 31.99 & 11.74 & 119.45 \\
\hline Facility & 295.12 & $2,125.51$ & 22.13 & $2,442.76$ \\
\hline \multicolumn{5}{|l|}{ Repository 1} \\
\hline Waste package & 323.23 & $1,698.84$ & 52.04 & $2,074.11$ \\
\hline Repository & $1,756.82$ & $7,197.41$ & 81.25 & $9,035.48$ \\
\hline \multicolumn{5}{|l|}{ Repository 2} \\
\hline Waste package & 207.51 & $1,108.63$ & 33.41 & $1,349.55$ \\
\hline Repository & 589.9 & $3,396.41$ & 41.9 & $4,028.21$ \\
\hline \multicolumn{5}{|l|}{ Totals } \\
\hline System & $20,359.23$ & & & \\
\hline DRS & 192.73 & & & \\
\hline
\end{tabular}


TABLE $6.2-10$

GA INTEGRATED MRS SALT X GRANITE

\begin{tabular}{|c|c|c|c|c|}
\hline & Capital & Operating & Decommissioning & Total \\
\hline DRS & 2.55 & 190.18 & & 192.73 \\
\hline \multicolumn{5}{|l|}{ Transportation } \\
\hline Truck & 23.22 & 211.52 & & 234.74 \\
\hline Rail RX & 94.09 & 388.24 & & 482.33 \\
\hline Rail MRS & 75.47 & 364.90 & & 440.37 \\
\hline \multicolumn{5}{|l|}{ MRS } \\
\hline Consolidation & 75.72 & 31.99 & 11.74 & 119.45 \\
\hline Facility & 295.12 & $1,967.43$ & 22.13 & $2,284.68$ \\
\hline \multicolumn{5}{|l|}{ Repository 1} \\
\hline Waste package & 327.02 & $1,329.68$ & 52.63 & $1,709.33$ \\
\hline Repository & $1,252.46$ & $3,795.62$ & 193.32 & $5,241.4$ \\
\hline \multicolumn{5}{|l|}{ Repository 2} \\
\hline Waste package & 207.51 & $1,108.63$ & 33.41 & $1,349.55$ \\
\hline Repository & 589.9 & $3,396.41$ & 41.9 & $4,028.21$ \\
\hline \multicolumn{5}{|l|}{ Totals } \\
\hline System & $15,890.06$ & & & \\
\hline DRS & 192.73 & & & \\
\hline
\end{tabular}


TABLE $6 \cdot 2-11$

GA INTEGRATED MRS TUFF $X$ GRANITE

\begin{tabular}{|c|c|c|c|c|}
\hline & Capital & Operating & Decommissioning & Total \\
\hline DRS & 2.55 & 190.18 & & 192.73 \\
\hline \multicolumn{5}{|l|}{ Transportation } \\
\hline Truck & 23.22 & 211.52 & & 234.74 \\
\hline Rail RX & 94.09 & 388.24 & & 482.33 \\
\hline Rail MRS & 95.45 & 483.22 & & 578.68 \\
\hline \multicolumn{5}{|l|}{ MRS } \\
\hline Consolidation & 75.72 & 31.99 & 11.74 & 119.45 \\
\hline Facility & 295.12 & $2,033.08$ & 22.13 & $2,350.33$ \\
\hline \multicolumn{5}{|l|}{ Repository 1} \\
\hline Waste package & 286.89 & $1,430.03$ & 46.19 & $1,763.11$ \\
\hline Repository & 722.8 & $4,277.95$ & 68.3 & $5,069.05$ \\
\hline \multicolumn{5}{|l|}{ Repository 2} \\
\hline Waste package & 207.51 & $1,108.63$ & 33.41 & $1,349.55$ \\
\hline Repository & 589.9 & $3,396.41$ & 41.9 & $4,028.21$ \\
\hline \multicolumn{5}{|l|}{ Totals } \\
\hline System & $15,975.45$ & & & \\
\hline DRS & 192.73 & & & \\
\hline
\end{tabular}


TABLE 6.3-1

RADIOACTIVE WASTE MANAGEMENT SYSTEMS COSTS (M1111on 1985 Dollars)

\begin{tabular}{|c|c|c|c|c|c|c|c|c|}
\hline & \multicolumn{8}{|c|}{ CRWM System } \\
\hline & \multicolumn{2}{|c|}{ Basalt/Grantte } & \multicolumn{2}{|c|}{ Salt/Granite } & \multicolumn{2}{|c|}{ Tuff / Granite } & \multicolumn{2}{|c|}{ DRS } \\
\hline & Undiscounted & Discounted & Und is counted & Discounted & Undiscounted & Discounted & Und I scounted & Discounted \\
\hline PRDA reference & 18,300 & 8,769 & 13,747 & 6,546 & 14,393 & 6,696 & 713 & 512 \\
\hline GA reference & 17,491 & 8,431 & 13,108 & 6,278 & 13,613 & 6,368 & 551 & 391 \\
\hline GA alternate & 20,358 & 10,032 & 15,889 & 7,821 & 15,975 & 7,736 & 193 & 153 \\
\hline
\end{tabular}


each of the three repository geology combinations are given for the PRDA and GA reference system and the GA integrated MRS system. DRS costs, both discounted and undiscounted, are shown for each of the three systems also.

The cash flows are given in Tables 6.3-2 through 6.3-10. Although WADCOM-MF does perform a discounting calculation, because of the nature of the combination of several computer runs to model one case (see Appendix D.2), it was elected to use electronic spreadsheets to do the present value analysis once the undiscounted cash flows were determined.

\subsection{REFERENCES}

6-1. Weston, Roy F., Inc., "WADCOM-MF-A Multiple Facility Waste Disposal Cost Model," working draft.

6-2. Weston, Roy F., Inc., "WADCOM-MF Runs for PRDA Reference Cases," draft, March 1985.

6-3. KEH R-83-96, "Monitored Retrievable Storage Conceptual Design Study: Dry Receiving and Handling Facility," Kaiser Engineers Hanford Company Report, January 1984.

6-4. Ganley, J. T., and J. A. Washington, "Monitored Retrievable Storage Conceptual System Studies: Closed Cycle Vault," GA Report GA-A17322, February 1984. 
TABLE 6.3-2

PRDA REFERENCE CASES DISCOUNTED COST ANALYSIS BASALT $X$ GRANITE REPOSITORIES

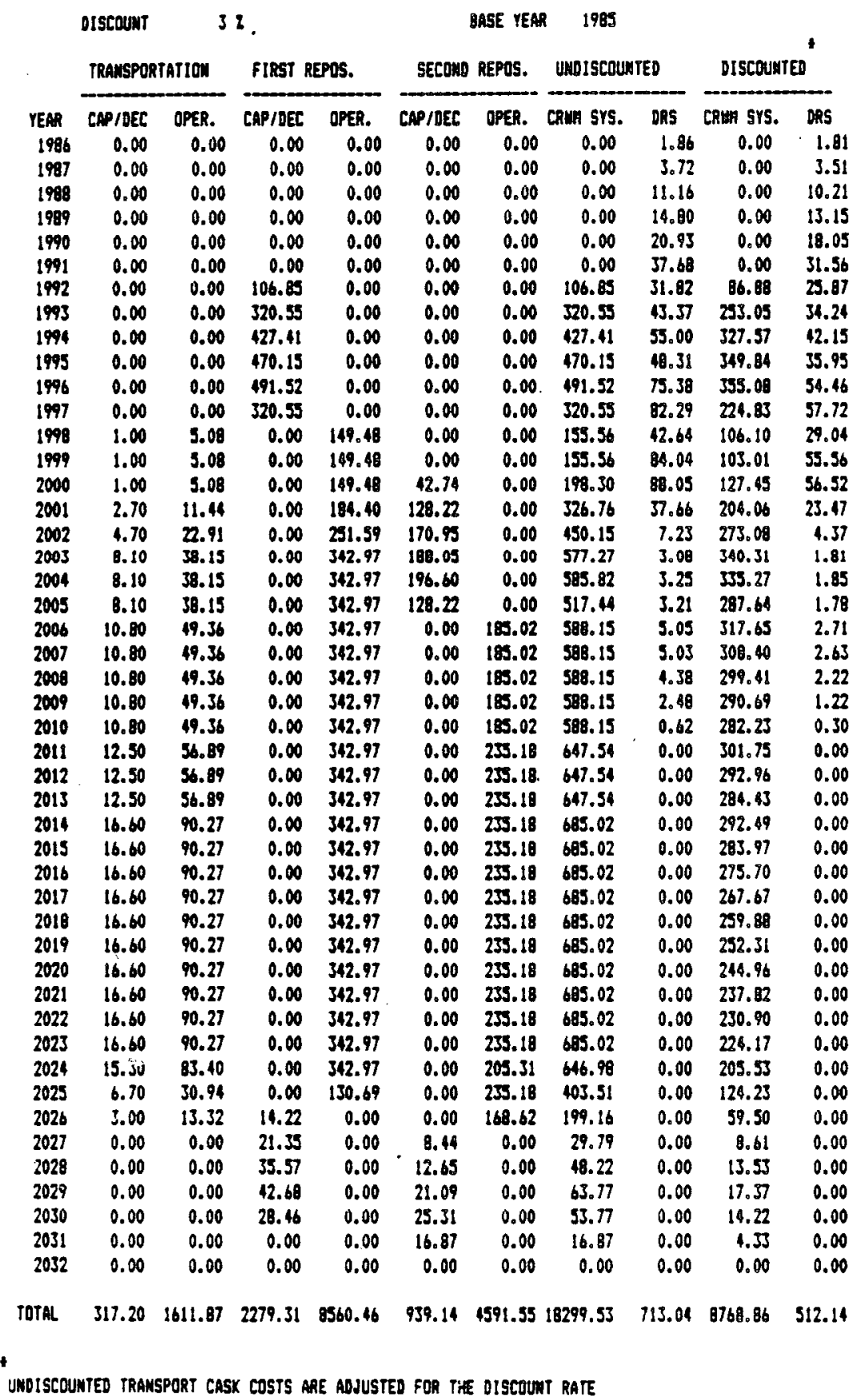


TABLE $6.3-3$

PRDA REFERENCE CASES DISCOUNTED COST ANALYSIS SALT $X$ GRANITE REPOSITORIES

\begin{tabular}{|c|c|c|c|c|c|c|c|c|c|c|}
\hline & ilscount & 3 & & & & BASE YEAR & 1985 & & & \\
\hline & TRAuspon & ATION & FIRST R & POS. & secondo & REPOS. & UndoIscoum & & DIscount & \\
\hline YEAR & CAPIOEC & OPER. & CAP/DEC & OPER. & CAP/DES & OPER. & canil srs. & Dins & canin sYs. & DRS \\
\hline 1996 & 0.00 & 0.00 & 0.00 & 0.00 & 0.00 & 0.00 & 0.00 & 1.86 & 0.00 & 1.81 \\
\hline 1997 & 0.00 & 0.00 & 0.00 & 0.00 & 0.00 & 0.00 & 0.00 & 3.72 & 0.00 & 3.51 \\
\hline 1988 & 0.00 & 0.00 & 0.00 & 0.00 & 0.00 & 0.00 & 0.00 & 11.16 & 0.00 & 10.21 \\
\hline 1999 & 0.00 & 0.00 & 0.00 & 0.00 & 0.00 & 0.00 & 0.00 & 14.80 & 0.00 & 13.15 \\
\hline 1990 & 0.00 & 0.00 & 0.00 & 0.00 & 0.00 & 0.00 & 0.00 & 20.93 & 0.00 & 18.05 \\
\hline $\begin{array}{l}\text { t991 } \\
\text { t992 }\end{array}$ & $\begin{array}{l}0.00 \\
0.00\end{array}$ & $\begin{array}{l}0.00 \\
0.00\end{array}$ & $\begin{array}{r}0.00 \\
80.44\end{array}$ & $\begin{array}{l}0.00 \\
0.00\end{array}$ & $\begin{array}{l}0.00 \\
0.00\end{array}$ & $\begin{array}{l}0.00 \\
0.00\end{array}$ & $\begin{array}{r}0.00 \\
80.44\end{array}$ & $\begin{array}{l}37.68 \\
31.82\end{array}$ & $\begin{array}{r}0.00 \\
63.41\end{array}$ & $\begin{array}{l}31.56 \\
25.87\end{array}$ \\
\hline 1993 & 0.00 & 0.00 & 241.33 & 0.00 & 0.00 & 0.00 & 241.53 & 43.37 & 190.51 & 34.24 \\
\hline 1994 & 0.00 & 0.00 & 321.79 & 0.00 & 0.00 & 0.00 & 321.79 & 55.00 & 246.63 & 12.15 \\
\hline 1995 & 0.00 & 0.00 & 53.96 & 0.00 & 0.00 & 0.00 & 353.96 & 49.31 & 263.38 & 55.95 \\
\hline 1996 & 0.00 & 0.00 & 370.05 & 0.00 & 0.00 & 0.00 & 570.05 & 75.38 & 267.53 & 54.46 \\
\hline 1997 & 0.00 & 0.00 & 241.53 & 0.00 & 0.00 & 0.00 & 241.53 & 82.29 & 169.26 & 57.72 \\
\hline 1998 & 1.00 & 3.43 & 0.00 & 118.08 & 0.00 & 0.00 & 122.51 & 12.64 & 93.60 & 29.04 \\
\hline 1999 & 1.00 & 3.43 & 0.00 & 118.08 & 0.00 & 0.00 & 122.51 & 84.04 & 81.16 & 55.56 \\
\hline 2000 & 1.00 & 3.43 & 0.00 & 118.08 & 42.14 & 0.00 & 165.25 & 68.05 & 106.23 & 56.52 \\
\hline 2001 & 1.70 & 7.71 & 0.00 & 130.74 & 128.22 & 0.00 & 268.57 & 37.66 & 167.51 & 23.47 \\
\hline 2002 & 3.40 & 15.39 & 0.00 & 154.66 & 170.95 & 0.00 & 34.40 & 7.23 & 208.90 & 4.37 \\
\hline 2003 & 6.10 & 25.64 & 0.00 & $187.0 \mathrm{t}$ & 188.05 & 0.00 & 406.80 & 3.08 & 239.87 & 1.81 \\
\hline 2004 & 6.10 & 25.64 & 0.00 & 187.01 & 196.60 & 0.00 & 415.35 & 3.25 & 237.76 & 1.85 \\
\hline 2005 & 6.10 & 25.64 & 0.00 & 187.01 & 128.22 & 0.00 & 346.97 & 3.21 & 192.98 & 1.78 \\
\hline 2006 & 8.80 & 36.65 & 0.00 & 187.01 & 0.00 & 185.02 & 417.68 & 9.05 & 225.11 & 2.71 \\
\hline 2007 & 8.80 & 36.65 & 0.00 & 187.01 & 0.00 & 185.02 & 417.68 & 5.03 & 219.16 & 2.63 \\
\hline 2008 & 8.80 & 36.85 & 0.00 & 187.01 & 0.00 & 185.02 & 417.68 & 4.38 & 212.70 & 2.22 \\
\hline 2009 & 8.80 & 36.85 & 0.00 & 187.01 & 0.00 & 185.02 & 417.68 & 2.48 & 206.58 & 1.22 \\
\hline 2010 & 0.80 & 36.85 & 0.00 & 187.01 & 0.00 & 185.02 & 117.68 & 0.62 & 200.56 & 0.30 \\
\hline 2011 & 10.50 & 4.38 & $0 . \infty$ & 187.01 & 0.00 & 259.18 & 477.07 & 0.00 & 222.46 & 0.00 \\
\hline 2012 & 10.50 & 44.38 & 0.00 & 187.01 & 0.00 & 235.18 & 177.07 & 0.00 & 215.98 & 0.00 \\
\hline 2013 & 10.50 & 4.38 & 0.00 & 197.01 & 0.00 & 235.18 & 477.07 & 0.00 & 209.69 & 0.00 \\
\hline 2014 & 14.00 & 69.30 & 0.00 & 187.01 & 0.00 & 255.18 & 505.49 & 0.00 & 216.03 & 0.00 \\
\hline 2015 & 14.00 & 69.30 & 0.00 & 187.01 & 0.00 & 235.18 & 505.49 & 0.00 & 209.73 & 0.00 \\
\hline 2016 & 14.00 & 69.30 & 0.00 & 107.01 & 0.00 & 255.18 & 505.49 & 0.00 & 203.63 & 0.00 \\
\hline 2017 & 14.60 & 69.30 & 0.00 & 187.01 & 0.00 & 235.18 & 305.49 & 0.00 & 191.69 & 0.00 \\
\hline 2018 & 14.00 & 69.30 & 0.00 & 187.01 & 0.00 & 255.18 & 505.49 & 0.00 & 191.94 & 0.00 \\
\hline 2019 & 14,00 & 69.30 & 0.00 & 187.01 & 0.00 & 255.18 & 505.49 & 0.00 & 186.55 & 0.00 \\
\hline 2020 & 14,00 & 69.30 & 0.60 & 187.01 & 0.00 & 235.18 & 505.49 & 0.00 & 180.92 & 0.00 \\
\hline 2021 & 14.00 & 69.30 & 0.00 & 187.01 & 0.00 & 255.18 & 505.49 & 0.00 & 175.65 & 0.00 \\
\hline 2022 & 14.00 & 69.30 & 0.00 & 187.01 & 0.00 & 255.18 & 505.49 & 0.00 & 170.53 & 0.00 \\
\hline 2023 & 14.00 & 69.30 & 0.00 & 187.01 & 0.00 & 235.18 & 505.49 & 0.00 & 165.57 & 0.00 \\
\hline 2024 & 12.70 & 62.25 & 0.00 & 187.01 & 0.00 & 205.31 & 467.27 & 0.00 & 148.57 & 0.00 \\
\hline 2025 & 6.70 & 30.24 & 0.00 & 111.04 & 0.00 & 235.18 & 383.16 & 0.00 & 117.99 & 0.00 \\
\hline 2026 & 3.00 & 13.32 & 23.15 & 0.00 & 0.00 & 168.62 & 210.09 & 0.00 & 62.76 & 0.00 \\
\hline 2027 & 0.00 & 0.00 & 37.72 & 0.00 & 8.44 & 0.00 & 46.16 & 0.00 & 13.34 & 0.00 \\
\hline 2028 & 0.00 & 0.00 & 62.87 & $0.00^{\circ}$ & 12.65 & 0.00 & 75.52 & 0.00 & 21.19 & 0.00 \\
\hline 2029 & 0.00 & 0.00 & 75.45 & 0.00 & 21.09 & 0.00 & 96.54 & 0.00 & 26.29 & 0.00 \\
\hline 2030 & 0.00 & 0.00 & 50.50 & 0.00 & 25.51 & 0.00 & 79.61 & 0.00 & 19.99 & 0.00 \\
\hline 2031 & 0.00 & 0.00 & 0.00 & 0.00 & 16.87 & 0.00 & 16.87 & 0.00 & 4.53 & 0.00 \\
\hline 2032 & 0.00 & 0.00 & 0.00 & 0.00 & 0.00 & 0.00 & 0.00 & 0.00 & 0.00 & 0.00 \\
\hline
\end{tabular}

TOTA. $264.30 \quad 1226.51 \quad 1860.39 \quad 4864.90 \quad 939.14 \quad 1991.55 \quad 13746.79 \quad 713.04 \quad 6549.98 \quad 312.14$

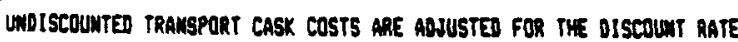


TABLE $6.3-4$

PRDA REFERENCE CASES DISCOUNTED COST ANALYSIS TUFF $X$ GRANITE REPOSITORIES

\begin{tabular}{|c|c|c|c|c|c|c|c|c|c|c|}
\hline \multirow[b]{3}{*}{ YEAR } & otscoum & 32 & 2 & & \multicolumn{2}{|r|}{ BASE YEAR } & \multicolumn{2}{|l|}{1985} & \multicolumn{2}{|r|}{$\because$} \\
\hline & \multicolumn{2}{|c|}{ Pranspontation } & \multicolumn{2}{|c|}{ FIRET REPOS. } & \multicolumn{2}{|c|}{ SEcono REPOS. } & \multicolumn{2}{|c|}{ WhISCOUNTED } & \multicolumn{2}{|c|}{ DISCOUNTED } \\
\hline & CAP/DEC & OPER. & CAP/DEC & OPER. & CAP/DET & OPER. & crith SYS. & Dis & cain srs. & DAS \\
\hline 1986 & 0.00 & 0.00 & 0.00 & 0.00 & 0.00 & 0.00 & 0.00 & 1.86 & 0.00 & 1.81 \\
\hline 1987 & 0.00 & 0.00 & 0.00 & 0.00 & 0.00 & 0.00 & 0.00 & 3.72 & 0.00 & 3.51 \\
\hline 1989 & 0.00 & 0.00 & 0.00 & 0.00 & 0.00 & 0.00 & 0.00 & 11.16 & 0.00 & 10.21 \\
\hline 1989 & 0.00 & 0.00 & 0.00 & 0.00 & 0.00 & 0.00 & 0.00 & 14.80 & 0.00 & 13.15 \\
\hline $\begin{array}{l}1990 \\
1991\end{array}$ & $\begin{array}{l}0.00 \\
0.00\end{array}$ & $\begin{array}{l}0.00 \\
0.00\end{array}$ & $\begin{array}{l}0.00 \\
0.00\end{array}$ & $\begin{array}{l}0.00 \\
0.00\end{array}$ & $\begin{array}{l}0.00 \\
0.00\end{array}$ & $\begin{array}{l}0.00 \\
0.00\end{array}$ & $\begin{array}{l}0.00 \\
0.00\end{array}$ & $\begin{array}{l}20.93 \\
37.68\end{array}$ & $\begin{array}{l}0.00 \\
0.00\end{array}$ & $\begin{array}{l}18.05 \\
31.96\end{array}$ \\
\hline 1992 & 0.00 & 0.00 & 53.33 & 0.00 & 0.00 & 0.00 & 53.53 & 31.82 & 43.36 & 29.87 \\
\hline 1993 & 0.00 & 0.00 & 160.00 & 0.00 & 0.00 & 0.00 & 160.00 & 43.37 & 126.31 & 34.24 \\
\hline 1994 & 0.00 & 0.00 & 213.34 & 0.00 & 0.00 & 0.00 & 213.34 & 55.00 & $165.5 t$ & 42.15 \\
\hline 1995 & 0.00 & 0.00 & 234.67 & 0.00 & 0.00 & 0.00 & 234.67 & 48.31 & 174.62 & 35.99 \\
\hline 1996 & 0.00 & 0.00 & 245.33 & 0.00 & 0.00 & 0.00 & 245.33 & 75.38 & 177.23 & 54.46 \\
\hline 1997 & 0.00 & 0.00 & 160.00 & 0.00 & 0.00 & 0.00 & 160.00 & 82.29 & 112.22 & 57.72 \\
\hline 1998 & 1.00 & 4.85 & 0.00 & 126.52 & 0.00 & 0.00 & 132.35 & 42.64 & 90.30 & 29.04 \\
\hline 1999 & 1.00 & 4.83 & 0.00 & 126.52 & 0.00 & 0.00 & 132.55 & 84.04 & 87.67 & 55.56 \\
\hline 2000 & 1.00 & 4.83 & 0.00 & 126.52 & 42.74 & 0.00 & 175.09 & 88.05 & 112.55 & 56.52 \\
\hline 2001 & 2.70 & 10.84 & 0.00 & 145.44 & 128.22 & 0.00 & 287.20 & 37.66 & 179.41 & 23.17 \\
\hline $\begin{array}{l}2002 \\
2003\end{array}$ & $\begin{array}{l}4.40 \\
7.10\end{array}$ & $\begin{array}{l}21.75 \\
36.20\end{array}$ & $\begin{array}{l}0.00 \\
0.00\end{array}$ & $\begin{array}{l}180.92 \\
227.03\end{array}$ & $\begin{array}{l}170.95 \\
188.05\end{array}$ & $\begin{array}{l}0.00 \\
0.00\end{array}$ & $\begin{array}{l}378.02 \\
458.38\end{array}$ & $\begin{array}{l}7.23 \\
3.08\end{array}$ & $\begin{array}{l}229.39 \\
270.32\end{array}$ & $\begin{array}{l}4.37 \\
1.81\end{array}$ \\
\hline 2004 & 7.10 & 36.20 & 0.00 & 227.03 & 196.60 & 0.00 & 166.93 & 3.25 & 267.32 & 1.85 \\
\hline 2005 & 7.10 & 36.20 & 0.00 & 227.03 & 128.22 & 0.00 & 390.55 & 3.21 & 221.69 & 1.78 \\
\hline 2008 & 10.50 & 47.41 & 0.00 & 227.03 & 0.00 & 185.02 & 469.96 & 5.05 & 254.07 & 2.71 \\
\hline 2007 & 10.50 & 97.41 & 0.00 & 227.03 & 0.00 & 165.02 & 169.96 & 5.05 & 246.67 & 2.63 \\
\hline 2008 & 10.50 & 47.41 & 0.00 & 227.03 & 0.00 & 185.02 & 169.96 & 4.38 & 239.49 & 2.22 \\
\hline 2009 & 10.50 & 47.41 & 0.00 & 227.03 & 0.00 & 185.02 & 469.96 & 2.18 & 232.51 & 1.22 \\
\hline 2010 & 10.50 & 47.41 & 0.00 & 227.03 & 0.00 & 189.02 & 469.96 & 0.62 & 225.71 & 0.30 \\
\hline 2011 & 12.20 & 54.94 & 0.00 & 227.03 & 0.00 & 255.18 & 529.55 & 0.00 & 246.91 & 0.00 \\
\hline 2012 & 12.20 & 54,94 & 0.00 & 227.03 & 0.00 & 255.18 & 529.35 & 0.00 & 239.72 & 0.00 \\
\hline 2013 & 12.20 & 54.94 & 0.00 & 227.03 & 0.00 & 253. 18 & 329.55 & 0.00 & 232.73 & 0.00 \\
\hline 2014 & 16.30 & 86.64 & 0.00 & 227.03 & 0.00 & 255.18 & 565.15 & 0.00 & 241.59 & 0.00 \\
\hline 2015 & 16.30 & 86.64 & 0.00 & 227.03 & 0.00 & 235.18 & 565.15 & 0.00 & 234.56 & 0.00 \\
\hline 2016 & 16.30 & 86.64 & 0.00 & 227.03 & 0.00 & 235.18 & 565.15 & 0.00 & 227.73 & 0.00 \\
\hline 2017 & 16.30 & 86.64 & 0.00 & 227.03 & 0.00 & 235.18 & 565.15 & 0.00 & 221.09 & 0.00 \\
\hline 2018 & 16.30 & 86.64 & 0.00 & 227.03 & 0.00 & 235.18 & 565.15 & 0.00 & 214.65 & 0.00 \\
\hline 2019 & 16.30 & 86.64 & 0.00 & 227.03 & 0.00 & 235.18 & 365.15 & 0.00 & 208.40 & 0.00 \\
\hline 2020 & 16.30 & 86.64 & 0.00 & 227.03 & 0.00 & 255.18 & 565.15 & 0.00 & 202.33 & 0.00 \\
\hline 2021 & 16.30 & 86.64 & 0.00 & 227.03 & 0.00 & 235.18 & 565.15 & 0.00 & 196.44 & 0.00 \\
\hline 2022 & 16.30 & 86.64 & 0.00 & 227.03 & 0.00 & 255.18 & 565.15 & 0.00 & 190.72 & 0.00 \\
\hline 2023 & 16.30 & 86.64 & 0.00 & 227.03 & 0.00 & 255.18 & 365.15 & 0.00 & 185.16 & 0.00 \\
\hline 2024 & 15.00 & 79.77 & 0.00 & 227.03 & 0.00 & 205.31 & 527.11 & 0.00 & 167.65 & 0.00 \\
\hline 2025 & 6.70 & 30.78 & 0.00 & 115.89 & 0.00 & 235.18 & 389.54 & 0.00 & 119.64 & 0.00 \\
\hline 2026 & 3.00 & 13.32 & 12.35 & 0.00 & 0.00 & 168.62 & 197.29 & 0.00 & 58.99 & 0.00 \\
\hline 2027 & 0.00 & 0.00 & 18.53 & 0.00 & 8.4 & 0.00 & 26.97 & 0.00 & 7,79 & 0.00 \\
\hline 2028 & 0.00 & 000 & 30.88 & 0.00 & 12.65 & 0.00 & 43.53 & 0.00 & 12.21 & 0.00 \\
\hline 2029 & 0.00 & 0.00 & 37.05 & 0.00 & 21.09 & 0.00 & 58.14 & 0.00 & 15.84 & 0.00 \\
\hline 2030 & 0.00 & 0.00 & 24.70 & 0.00 & 25.31 & 0.00 & 50.01 & 0.00 & 13.22 & 0.00 \\
\hline 2031 & 0.00 & 0.00 & 0.00 & 0.00 & 16.87 & 0.00 & 16.87 & 0.00 & 4.33 & 0.00 \\
\hline 2032 & 0.00 & 0.00 & 0.00 & 0.00 & 0.00 & 0.00 & 0.00 & 0.00 & 0.00 & 0.00 \\
\hline TOTAL & 308.20 & 1547.82 & 1190.18 & 5816.46 & 939.14 & 1591.55 & 14393.35 & 713.04 & 6696.03 & 512.14 \\
\hline
\end{tabular}


TABLE $6.3-5$

GA REFERENCE CASES DISCOUNTED COST ANALYSIS BASALT $X$ GRANITE REPOSITORIES

\begin{tabular}{|c|c|c|c|c|c|c|c|c|c|c|}
\hline & DISCOLHT & \multicolumn{2}{|c|}{35} & & \multicolumn{2}{|c|}{ BASE YEAR } & \multicolumn{2}{|l|}{1955} & \multirow{2}{*}{\multicolumn{2}{|c|}{+}} \\
\hline & \multicolumn{2}{|c|}{ TRAMSPORTATION } & \multicolumn{2}{|c|}{ FISST REFOS. } & \multicolumn{2}{|c|}{ SECOHD REPOS. } & \multicolumn{2}{|c|}{ GNOISCOHE EN } & & \\
\hline & & & & & & & & & & \\
\hline YEAR & CAP /DEC & OPER. & CAP IDEC & QPER. & CAPIDEC & OPER. & CRHA SYS. & LfE & Cown Jy. & 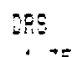 \\
\hline 1996 & 0.20 & 0.28 & 0.00 & 0.88 & 0.28 & 8.28 & 3.30 & 1.37 & 2.2 & $\therefore: E$ \\
\hline 1987 & 3.30 & 8.00 & 8.37 & 0.23 & 0.23 & 8.20 & 2.23 & $2.7 !$ & 3.22 & $2 .: 1$ \\
\hline 1988 & 3.20 & 8.30 & 3.20 & 0.80 & $8.8 n$ & 3.32 & 0.20 & 3.31 & 2.83 & 7.23 \\
\hline 1989 & 8.80 & 7.2. & 0.20 & 8.30 & 0.08 & 8.20 & 3.28 & 11.32 & 3.23 & 3.77 \\
\hline 1998 & 8.80 & 8.80 & 8. 00 & 8.08 & 3.20 & 0.38 & 0.20 & 15.59 & 8.22 & 12.5 \\
\hline $199 !$ & 0.63 & 0.20 & 8.08 & 8.20 & 8.38 & 8. 20 & 0.30 & 20.27 & 3.22 & Z..s: \\
\hline 1992 & 3.28 & 0.88 & 186.74 & 8.80 & 0.08 & 8.28 & $: 06.74$ & 33.72 & 26.79 & $1: 2 \%$ \\
\hline 1997 & 0.28 & B. 28 & 328.21 & 8.20 & 8.08 & 3.80 & 320.21 & 8.32 & IEn. & $25 .::$ \\
\hline 1994 & 8.28 & 0.38 & 426.95 & 3.80 & 3.30 & 0.22 & 426.95 & 43.98 & 87.2 & 31.19 \\
\hline 1995 & 0.38 & 3.38 & 469.64 & 0.28 & 3.22 & 2.38 & 459.64 & $35.2 !$ & 39.78 & $8.7 \%$ \\
\hline 1996 & D. & 3.20 & 498.99 & 0.88 & 1.20 & 0.28 & 492.99 & ร..:8 & 304,7 & $03.5 ;$ \\
\hline 1797 & 8.83 & 3.28 & $320.2 !$ & 3.38 & Q. 20 & 0.30 & 320.21 & 61.28 & $27 \div 59$ & 4.2 \\
\hline 1998 & 1.84 & 3.95 & 3.00 & 149.48 & 8.38 & 3.22 & $: 57.47$ & Z2.JE & QSE.S & 21.84 \\
\hline 1999 & 1.84 & 3.95 & 8.88 & 149,48 & 0.89 & 3.22 & $: 54.87$ & $6.7:$ & $: 32 .: 0$ & $4.5 \%$ \\
\hline 2823 & 1.34 & 3.95 & 0.28 & 149.48 & 42.65 & 3.32 & $: 97.12$ & $65.7 !$ & 226.53 & $\because 2 . Z$ \\
\hline 2021 & 1.84 & 9.98 & 3.38 & 184.48 & 127.37 & 3.82 & 32.29 & 38.73 & 381.31 & 17.72 \\
\hline 2002 & 2.79 & 17.99 & 8.30 & 251.59 & 172.49 & 2.32 & 442.56 & 6.67 & 253.77 & 9.34 \\
\hline 2883 & 4.87 & 29.94 & 0.88 & 342.97 & 187.53 & 0.28 & $55 \mathbf{5} .31$ & 3.39 & כיר.גיר & $\therefore 23$ \\
\hline 2024 & 4.87 & 33.03 & 0.88 & 342.97 & 196.86 & כ. 30 & 579.93 & $4.1:$ & $\therefore 7.7 !$ & 2.24 \\
\hline 2225 & 4.87 & 33.98 & จ. $2 \mathrm{n}$ & 342.97 & 127.87 & 8.82 & 588.71 & 4.35 & 232,35 & $2.2 !$ \\
\hline 2086 & 6.63 & 38.68 & 0. 30 & 342.97 & 0.30 & 135.22 & 575.22 & 3.35 & 39.25 & $\therefore .9$ \\
\hline 2007 & 6.63 & 38.53 & 0.82 & 342.97 & 0.28 & 135.32 & 573.15 & $\vdots .3$ & 33.31 & 3.3 \\
\hline 2038 & 6.63 & 38.68 & 8.30 & 342.97 & 8.28 & 185.92 & 575.29 & 3.52 & $291 . \geq !$ & $\therefore: 2$ \\
\hline 2389 & 6.65 & $38.5 \overline{3}$ & 3.88 & 342.97 & 8.00 & 185.82 & 573.15 & $5 .: 4$ & 223.79 & $\therefore: 5$ \\
\hline 2813 & 6.63 & 30.08 & ว. 20 & 342.97 & 2.22 & 185.02 & 573.22 & 3.79 & Z4.5E & $3 . .7$ \\
\hline 2311 & 7.34 & 42.31 & 0.88 & 342.97 & 0.80 & 235.18 & 627.82 & 2.33 & 291.78 & 2.32 \\
\hline 2012 & 7.34 & 44.32 & 2.28 & 342.97 & 0.98 & 235.13 & 629.21 & 2.32 & 294.9 & 2.28 \\
\hline 2315 & 7.34 & 44.32 & 0.38 & 342.97 & 2.32 & 235.18 & $\$ 29.31$ & 3.20 & 276.13 & 3.30 \\
\hline 2814 & 7.34 & 44.32 & 0.00 & 342.97 & ง..28 & 203.18 & 529.21 & 3.30 & 263.25 & 2.98 \\
\hline 2015 & 7.34 & 44.32 & 8.28 & 342.97 & 3.82 & 233.18 & $539.8 !$ & 3.98 & $2 \leq 2,25$ & 3.22 \\
\hline 2016 & 7.34 & 44.32 & 0.08 & 342.97 & 8.20 & 235.18 & $229.8 !$ & a.23 & 252,57 & 2.23 \\
\hline 2017 & 7.34 & 44.32 & 0.28 & 342.97 & 0.20 & 235.18 & 629.81 & 3.28 & 245.31 & 2.32 \\
\hline 2818 & 7.34 & 44.32 & 8.28 & 342.97 & 0.98 & 2.5. 18 & 59.81 & 9.30 & $28 .: 7$ & :. \\
\hline $28 \div ?$ & 7.34 & 44.32 & 8.29 & 342.97 & 8.32 & $235 . ! 3$ & 229.31 & 8.30 & 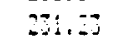 & 3.22 \\
\hline 2323 & 7.24 & 44.32 & 3.88 & 342.97 & 3.82 & 235.18 & 629.81 & 2.22 & $3: 52$ & $\therefore .3$ \\
\hline 2021 & 7.34 & 44.32 & 8.28 & 342.97 & 0.00 & 285.18 & $327.8 !$ & 3.22 & $\because 97.7$ & 3.32 \\
\hline 2822 & 7.34 & 44.32 & 0.88 & 342.97 & 2.80 & $25 e .18$ & 62?.2: & 3.28 & $\because 1 . \vdots:$ & 2.2 \\
\hline 2323 & 7.84 & 44.32 & 3.00 & 342.97 & 0.82 & 235.13 & 629.81 & 3.23 & $23 E \div 4$ & $\therefore 22$ \\
\hline 2224 & 6.63 & 42.96 & 0.00 & 342.97 & 3.28 & 2as. ¿̇! & EפE. & 3.30 & ISE, & 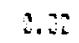 \\
\hline 2025 & 2.79 & 15.39 & 0.28 & 138.69 & 0.88 & 25.18 & 394.35 & 3.23 & $: 17,5$ & 2.23 \\
\hline 2926 & 1.04 & 3.61 & $: 4.22$ & 8.82 & 0.30 & 165.62 & 172.47 & 3.20 & $5: 77$ & $\therefore .2$ \\
\hline 2227 & 3.38 & 0.08 & 24.34 & 3.80 & 3.43 & 1. 13 & 39.77 & 3.23 & $\vdots .68$ & 3.23 \\
\hline 2023 & 3.23 & 3.10 & 35.56 & 0.20 & 12.85 & 2.38 & 48.21 & 3.23 & 1250 & 2.20 \\
\hline 2829 & 8.03 & 0.30 & 42.67 & 8.80 & 21.28 & 0.28 & 53.75 & 3.32 & نे. & d.23 \\
\hline 2250 & ว. .00 & 8.20 & 28.45 & 2.30 & $25.2 ?$ & 3.20 & 30.74 & 3.22 & $: 1.22$ & $\therefore .2$ \\
\hline $232 !$ & 0.02 & 3.39 & 3.33 & 3.22 & 16.36 & 3.23 & $\$ 2.30$ & i. 32 & $\therefore$ & 2.22 \\
\hline 2272 & 3.32 & 8.88 & 2.28 & 3.88 & $3.2 \mathrm{n}$ & 3.38 & 3.82 & 3.20 & 3.93 & $\therefore a$ \\
\hline & $162.6 !$ & $9: 4.75$ & 6.73 & 2.45 & $=96.7$ & 6 & 91.12 & $543.1 ?$ & $M 2.15$ & $22 .=8$ \\
\hline
\end{tabular}


TABLE $6.3-6$

GA REFERENCE CASES DISCOUNTED COST ANALYSIS SALT $X$ GRANITE REPOSITORIES

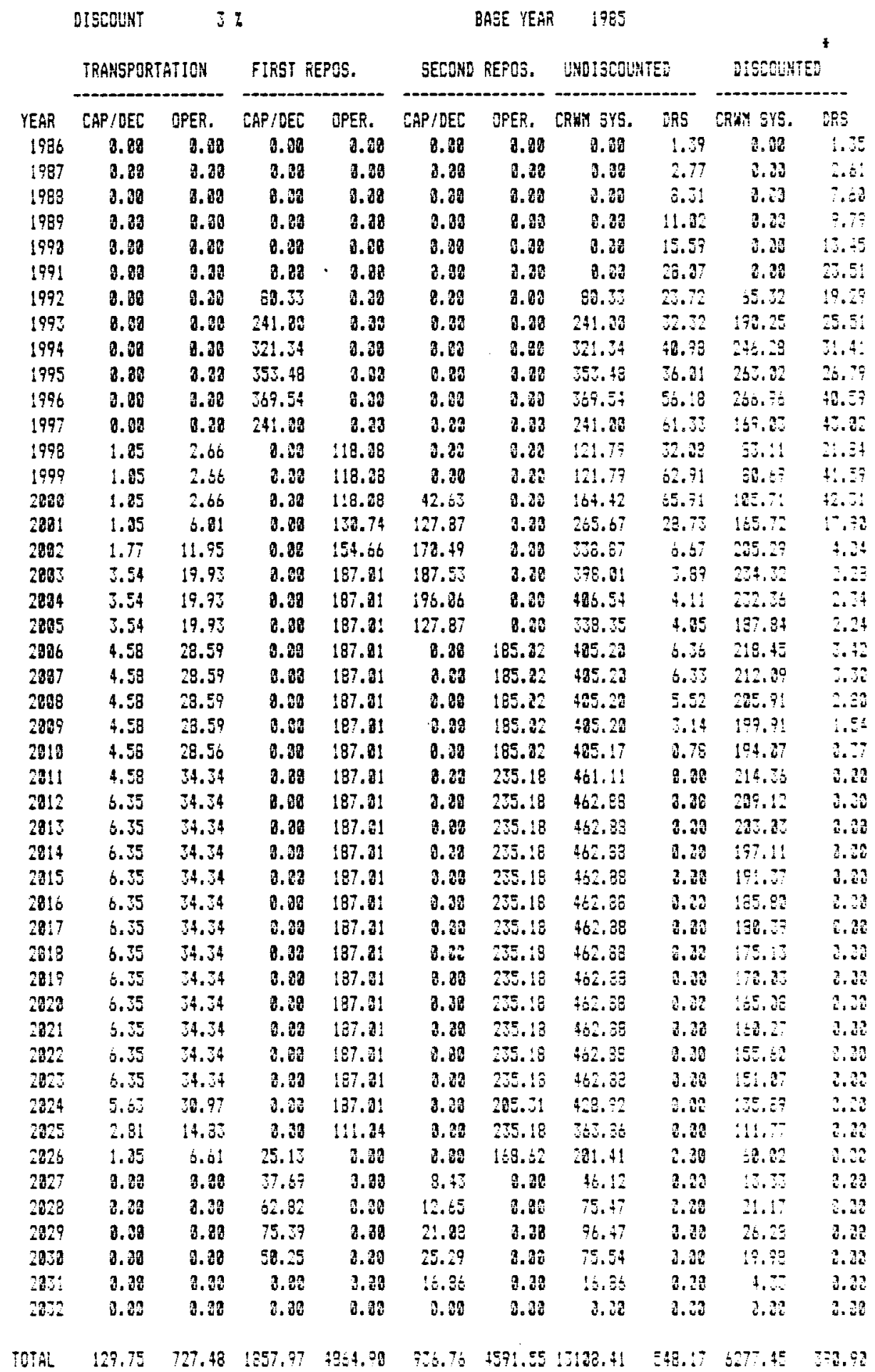


TABLE $6.3-7$

GA REFERENCE CASES DISCOUNTED COST ANALYSIS TUFF X GRANITE REPOSITORIES

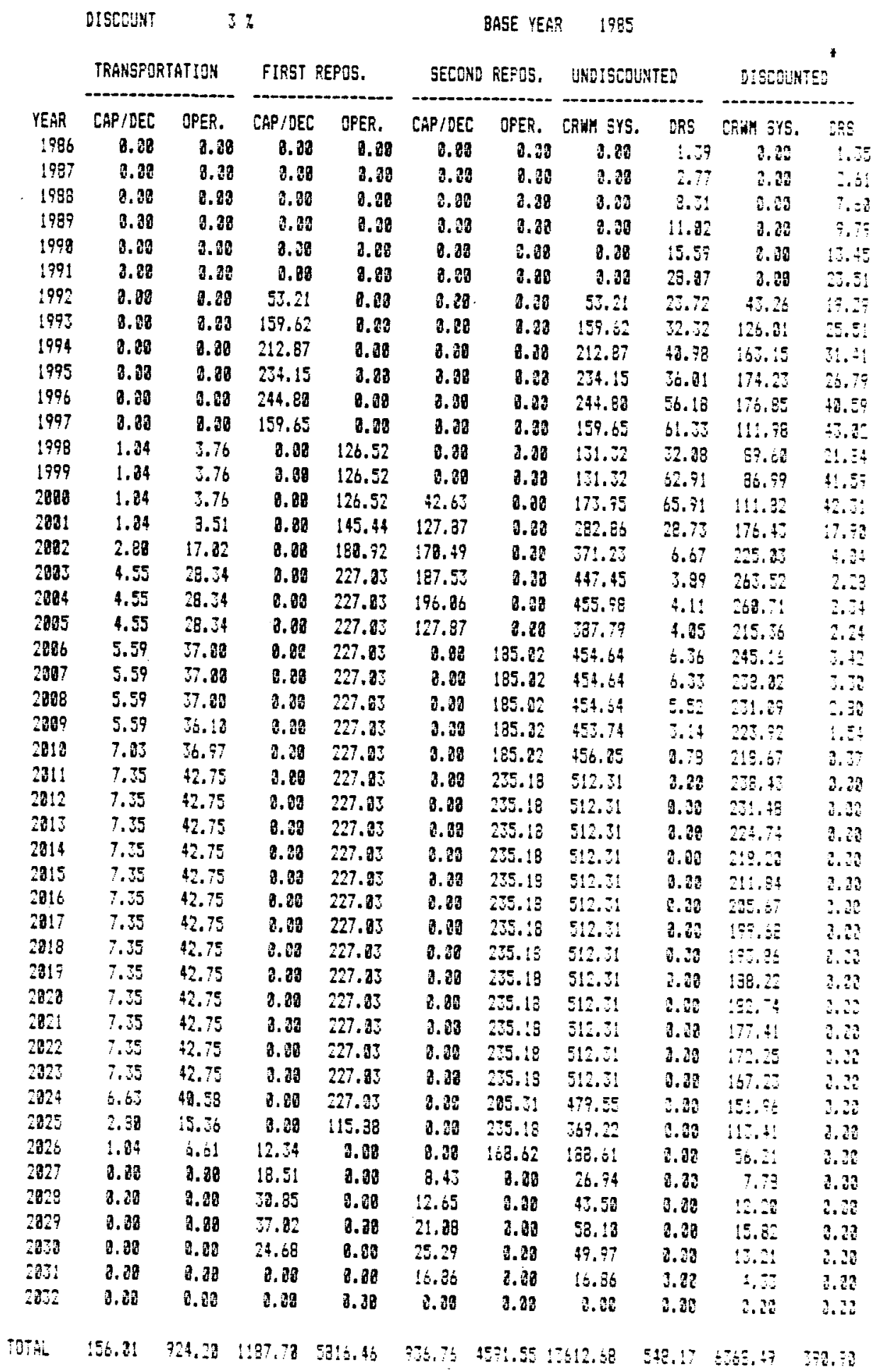


TABLE 6. 3-8

GA INTEGRATED MRS CASE DISCOUNTED COST ANALYSIS BASALT X GRANITE REPOSITORIES ( $\$$ Million 1985)

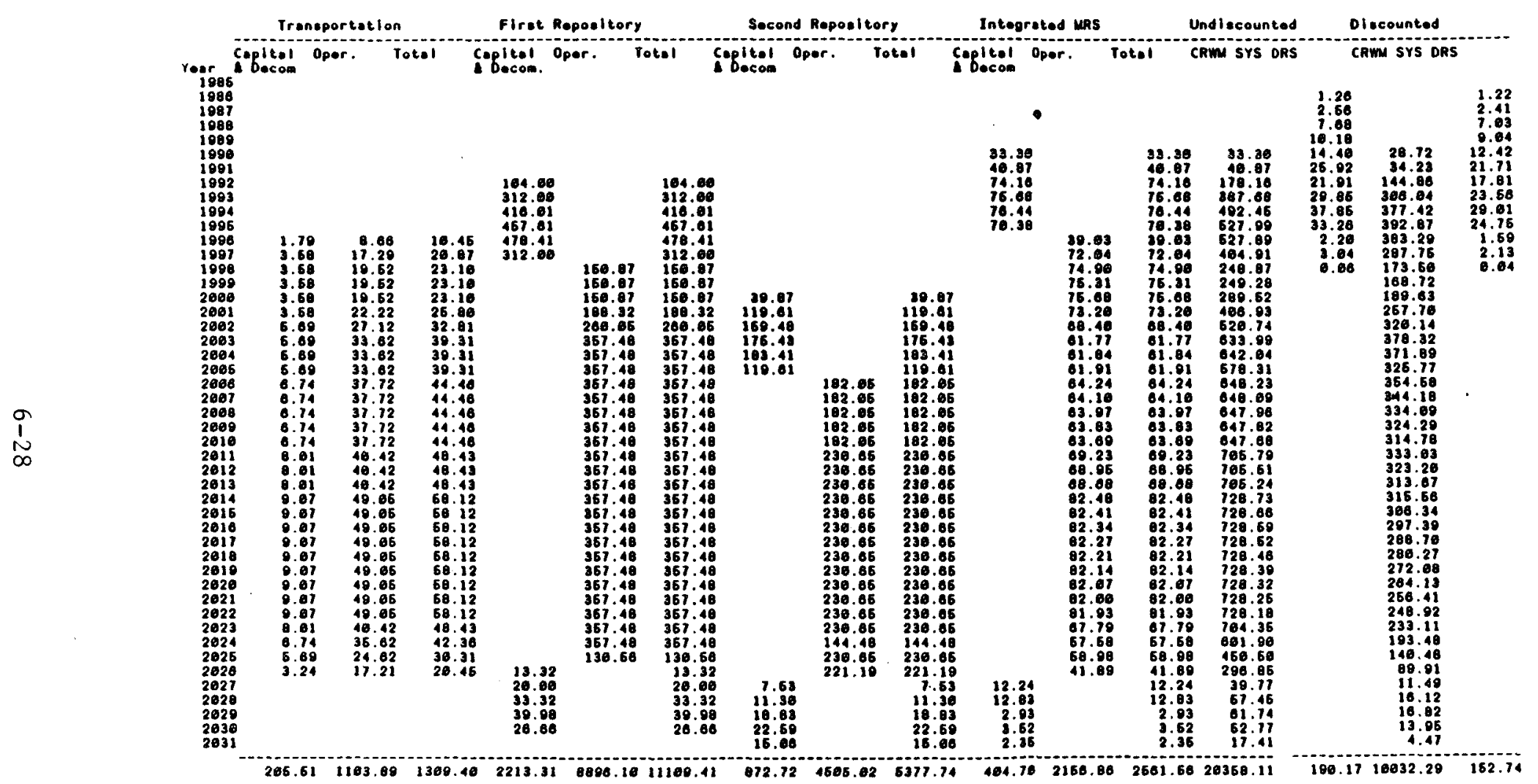


TABLE $6.3-9$

GA INTEGRATED MRS CASE DISCOUNTED COST ANALYSIS SALT X GRANITE REPOSITORIES ( $\$$ Milion 1985)

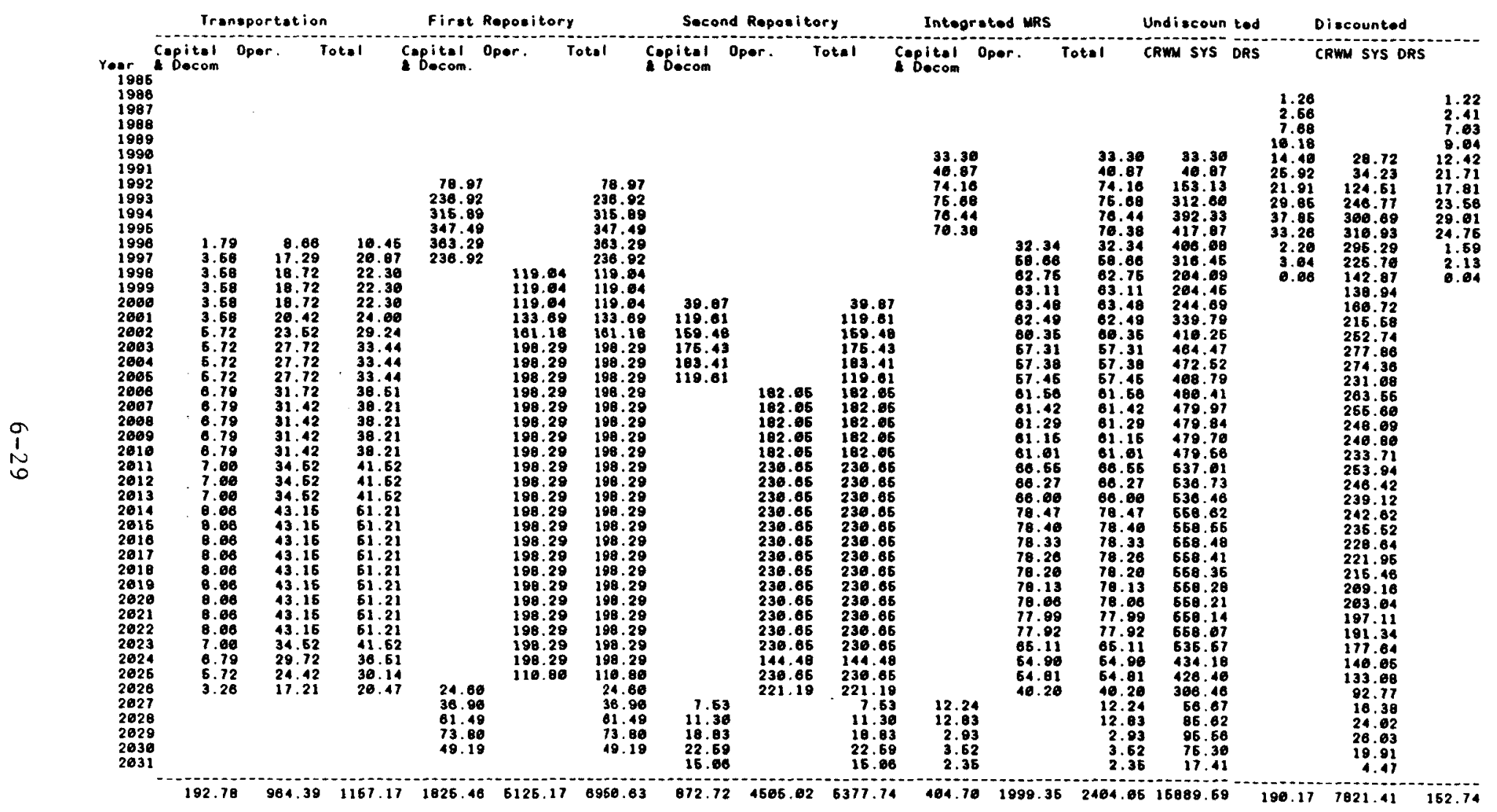


TABLE $6.3-10$

GA INTVEGRATED MRS CASE DISCOUNTED COST ANALYSIS TUFF X GRANITE REPOSITORIES

(\$ Million 1985)

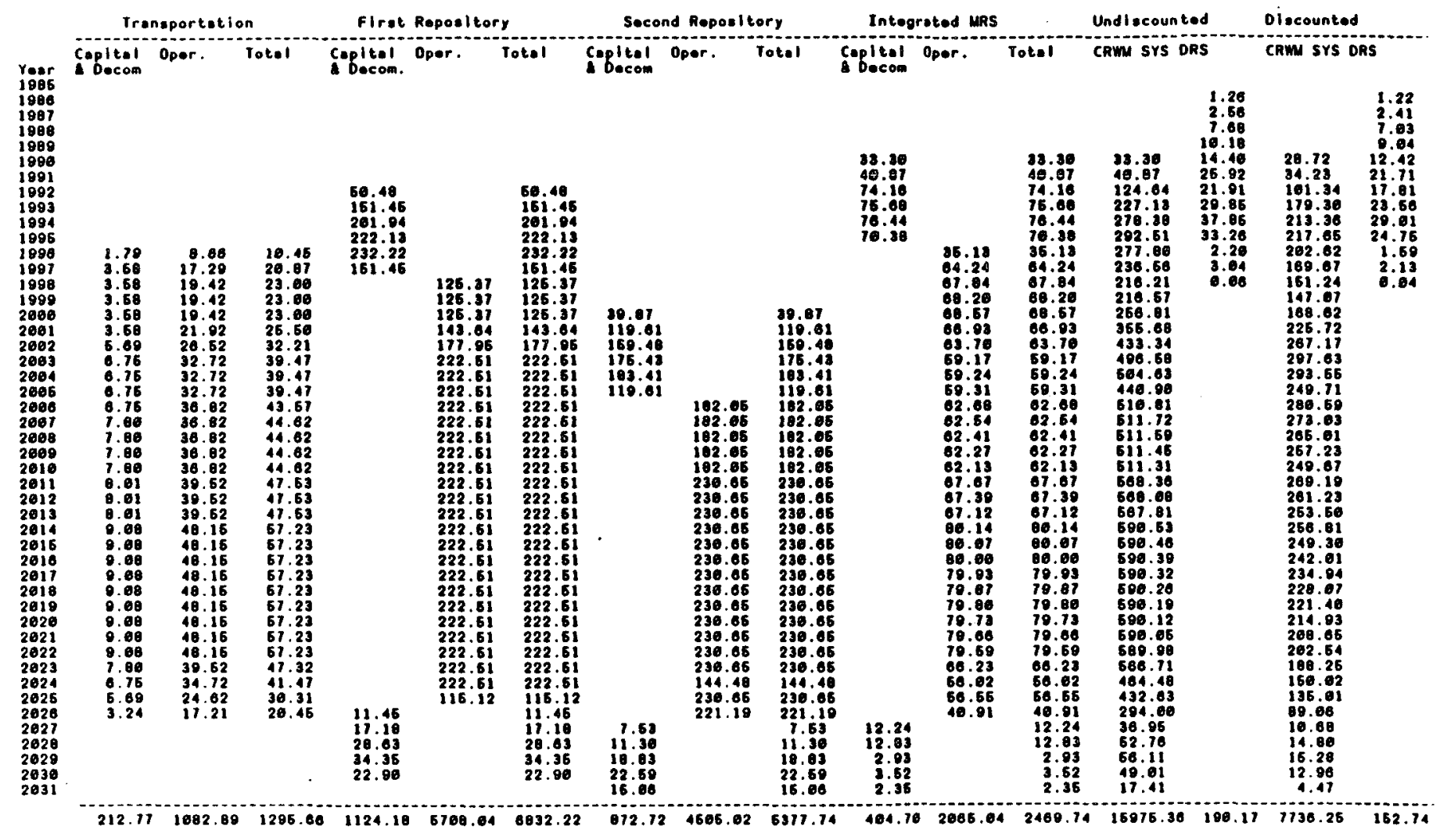




\section{SYSTEM FEASIBILITY}

\subsection{TECHNICAL FEASIBILITY}

The universal canister as described in Section 5 is technically feasible. It requires standard, readily avallable materials, it can be fabricated using existing manufacturing processes, and it can be handled and processed with existing equipment and facllities. The concept does not require licensing and canisters.

The feasibility of the CRWM system is enhanced with the universal canister. The CRWM system will take many years to implement and the current reference system may undergo several changes before it is fully 1mplemented. The universal canister allows the CRWM system to accommodate these changes while minimizing their impact. System feasibility is enhanced by providing flexibility in the system through the use of the universal canister.

\subsubsection{Flexibility in Storage and Transportation}

The feastbility of the universal canister system is due, in part, to the flexibility it provides to the CRWM system. This section will discuss the flexibility provided by the universal canister on the handling, storage, and transport of the spent fuel from reactor pool storage to repository disposal.

The basic premise of the universal canister concept is that the spent fuel is placed in a canister while it is in the reactor pool and remains in the canister either as intact or consolidated fuel during all possible functions which could take place prior to, and possibly including, final disposal. By introducing the canister at the first stage of 
fuel handling, the fuel has been put into a clean standard form which will be capable of interfacing with all potential changes to the current reference CRWM system, as described previously.

The flexibility provided by the universal canister increases as the CRWM system deviates from the current reference system. In the reference system, flexibility is enhanced with the universal canister at the reactor plant during handling and storage, but when fuel is shipped directly from reactor pools to the repository the canister itself provides little benefit during transport of the spent fuel and only minor benefit at the repository receiving facility versus shipping the fuel base in similar-sized cask. However, if the CRWM system becomes more complex with the introduction of intermediate facilities for storage and processing, the flexibility provided by the universal canister becomes an important asset during normal system operation and is necessary for keeping the system operational under abnormal conditions. The following section provides an evaluation of the flexibility of the universal canister in each component of the CWMS.

7.1.1.1. At-Reactor Pool Storage. If the reactor pool has space available for storing six universal canisters, these canisters can be preloaded with fuel while awaiting recelpt and handling of the shipping or storage casks. An 18-element rail cask can be quickly loaded with six canisters after being lowered in the pool rather than loading 18 individual elements. The operation results in reduced contamination, since the crud-coated elements are not being handled while the cask is in the pool. Any loose crud resulting from loading the canisters has been cleaned up by the pool cleanup system. It is also possible to load the canister while these are in the casks if space is a problem in the pool.

Once in the canisters, the fuel can easily be moved from storage cask to shipping cask or to temporary pool storage. It can be loaded into a truck or a rail cask and into a single or multiple-canister 
storage cask. Each transfer results in the movement of 3 PWR or 6 BWR fuel assemblies without the attendant contamination.

7.1.1.2. At-Reactor Dry Storage. The flexibility of an at-reactor dry storage system is enhanced with universal canisters. Since the canister is standard for all fuel types, exchangability is possible between PWR and BWR spent fuel and between reactor sites. Storage casks built to the universal canister requirements will interface with all the fuel in the system; therefore, an inventory of these casks can be fully utilized as storage requirements change between reactor sites.

The storage casks can be maintained essentially free of radioactive contamination, making them easier to move between reactors and easier to inspect and test.

7.1.1.3. Away-From-Reactor Dry Storage. Spent fuel may have to be stored at facilities such as a backup MRS or FIS while it awaits further handling and processing. The universal canister provides a standard storage package for these storage facilities to handle. Since these facilities would be temporary, they should be kept simple in design, inexpensive, and contamination free. Several smaller facilities on government reservations may be provided. This would result in multiple reactor types shipping to multiple storage sites followed by further shipments from multiple storage sites to an integrated MRS or multiple repositories.

In the event that away-from-reactor storage is necessary because of problems in implementing the CRWM system, flexibility provided by a universal canister is essential. Loading the fuel in a universal canister at the reactor results in a standard package for all fuel types. This package can then be handled and shipped easily between any number or type of facility. 
7.1.1.4. Centralized Processing. If centralized processing is adopted, such as in the form of an integrated MRS, where all the spent fuel is shipped for processing prior to shipment to the repository for disposal, a universal canister concept is required to provide needed flexibility within this processing facility.

Without a universal canister, the facility's operation will totally depend on all systems working as planned all the time, or the facility must include excessive redundant systems. Such a facility will be receiving fuel at a rate as high as $5400 \mathrm{MTU} / \mathrm{year}$ which, if operated 250 days/year, equals 47 PWR or 118 BWR spent fuel elements per day. An unplanned one-month shut down of the processing line requires immediate storage of $1410 \mathrm{PWR}$ or $3549 \mathrm{BWR}$ fuel elements. The universal canister allows the spent fuel to go directly into the concrete storage cask if processing problems occur.

After fuel rod consolidation, the fuel can be repackaged in the universal canister for continued system flexibilty. This allows the fuel to be stored in the concrete storage cask if the repository cannot receive the fuel at that particular time, the packaging process has not been selected, or the shipping is delayed, etc.

With the universal canister, it is not necessary to overpack at the processing facility. With the fuel safely contained in the canister, it can be shipped to the repository in the same casks that were used for shipping it from the reactors. If limited storage is avallable at the processing facility, the fuel can be shipped to an alternate storage site until it can be shipped to the repository.

The same contamination-free environment can be provided at the processing/storage facility, with all the contamination limited to the rod consolidation cell. This allows hands-on maintenance of all remote equipment associated with receiving, storage, packaging, and shipment of the fuel. 
7.1.1.5. Repository Operation. Under the universal canister concept, the repository always receives spent fuel in a canister. The canister may contain intact or consolidated fuel depending on the CRWM system selected. In the reactor-to-repository system, the canister will contain intact fuel which will require consolidation. In this system, the canister will provide flexibility at the repository during the receiving and storage phase, since all remote handling and storage systems can be identical. Also, since the fuel is handled in multiple units, the number of cask handling systems and the cask turnaround times may be reduced, although this could not be shown for the level of study performed during the PRD program.

In the integrated MRS system, the canister contains the same quantity of fuel that will go into the waste package. Therefore, in addition to the flexiblilty for receiving and storage indicated above, the canister provides flexibility throughout the packaging, transport, and emplacement system. Since the repository is processing a single-package configuration, all process lines are identical and interchangeable. Also, since the canisters are free of loose contamination, all equipment and systems at the repository will remain essentially clean, allowing hands-on maintenance.

7.1.1.6. Transportation. Flexibility in transportation requires a standard package. Currently there are many different types of spent fuel assemblies. If transportation systems are customized to accept each type of fuel, the system would become very inflexible. A standard package, as provided by the universal canister, provides maximum flexibility, allowing interchange of both fuel and shipping equipment between different reactors and between a reactor and the repository or any intermediate facilities such as as integrated MRS. 
Examples of the transportation flexibility provided by the universal canister are given below:

1. A utility ships BWR fuel in a truck cask to a PWR reactor for dry storage and later shipment to the integrated MRS in a rail cask.

2. A rail cask unloads its PWR fuel canisters at the MRS and is shipped to a BWR for its next load.

3. A rail cask arrives at the integrated MRS from a reactor, unloads its six intact fuel canisters, loads six consolidated fuel canisters, and leaves for the tuff repository.

\subsubsection{Flexibility of Universal Canister for Waste Packaging}

The proposed universal canister design appears to offer significant potential flexibility for meeting repository design waste package heat loads for all repository media under consideration. Thus, potential flexibility can be particularly useful for accommodating the increasing heat load distribution over time for fuel transferred to the repository. This latter flexibility could only be realized if a more flexible policy related to rod consolidation were adopted as part of the overall waste treatment strategy.

The universal canister capability for waste packaging can be assessed under two waste repository design policies which, for purposes of this discussion, are identified as (1) a fixed design basis policy, or (2) a flexible design basis policy. In this context, the current repository design basis may be considered as "fixed" in that it assumes all fuel is consolidated in all four types of repository media and a media-specific standard design basis waste package configuration, appropriate for 33,000 MWd/MT burnup and 10 year cooling, has been identified for each type of repository. 
TABLE $7.1-1$

WASTE PACKAGE COMPATIBILITY - FIXED DESIGN BASIS

\begin{tabular}{|c|c|c|c|c|c|}
\hline \multirow[b]{2}{*}{$\begin{array}{c}\text { Repository } \\
\text { (Consolidated) }\end{array}$} & \multirow[b]{2}{*}{$\begin{array}{l}\text { Heat Load }(\mathrm{a}) \\
\mathrm{kW} / \text { Package }\end{array}$} & Reference & \multirow{2}{*}{ 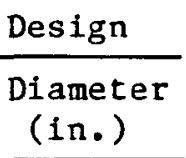 } & \multicolumn{2}{|c|}{ GA Design } \\
\hline & & No. PWR & & No. PWR & $\begin{array}{l}\text { Diameter } \\
\text { (in.) }\end{array}$ \\
\hline Tuff & 3.3 & 6 & 27.6 & 6 & 26 \\
\hline Salt & 6.6 & $12(10)^{(b)}$ & 25.2 & 8 & 26 \\
\hline Basalt & 2.2 & 4 & 13.2 & 4 & 26 \\
\hline Granite & 3.3 & 6 & 27.6 & 6 & 26 \\
\hline
\end{tabular}

(a) For 33,000 MWd/MTU at 10-year cooling.

(b) 10 PWR in salt repository now under consideration. 
Table 7.1-1 summarizes both the current DOE waste package designs for each repository media as well as the equivalent capabilities for the universal canister for the "fixed" design basis as discussed above. It is seen that a good degree of compatibility exists between the two designs for the package sizes and payload for the tuff, salt, and granite repositories. The GA design is apprectably larger than the current reference basalt package for the same assumed MTU and package heat load loading. The larger surface/volume ratio for the universal canister might allow an increased heat load/package for the basalt case, but this has not been evaluated.

However, even for the current design basis strategy, a combination of package sizes and/or packages per acre will, be required over time to meet the varying consolidated rod heat loads that result from higherburnup and lower-aged fuel receipts; 1.e., the design basis will not remain "fixed." A very interesting assessment of the varying package designs that may be required to more economically handle the dynamic spectrum of fuel to the repositories was made by NUS and reported in NUS-4607 (Ref. 7-1).

Another approach is to consider a more "flexible" design basis approach that is somewhat different than the approach taken in the NUS study. This approach, in which the universal canister looks attractive, involves the defining of a combination of possible assembly, assembly and consolidated rods, or just consolidated rod loadings per canister which would, in combination, yield a nearly constant media-specific package heat load over time for the time frame of repository operations.

To realize the potential benefit of this strategy would require that the DOE ground rules on rod consolidation be somewhat modified. For example, in this strategy there would continue to be $100 \%$ rod consolidation for fuel into a salt repository, but in the case of tuff or granite media approximately $85 \%$ to $90 \%$ of the fuel would be consolidated, while the hottest assemblies to be shipped in the later years of 
repository operation would not be consolidated. In the more limiting basalt case, only about $50 \%$ to $60 \%$ of the fuel would be consolidated in this strategy.

A strategy based on this concept should prove to be cost effective, since it may not be cost effective to consolidate very hot fuel in any case, as such fuel would require more shielding in the consolidation facility and the higher shielding requirement and heat load would complicate the storage, transport, and burial package design(s). This could prove to be particularly true in the integrated MRS mission, which currently calls for a minimum storage holdup in later years when the "hottest" fuel, with minimal aging at the MRS, is to be encapsulated and shipped to the repository for burial.

Inventory analysis, as discussed in Sections 2.3 and 2.4 , shows that package systems based on the current design criteria are capable of handling only $~ 50 \%$ (reference burnup) or $25 \%$ (extended burnup) of the total fuel inventory over time, neglecting the additional aging in an MRS. The actual capability for handing the fuel to be received in the later years is considerably less than this effective overall capability, since it is the much reduced capability in the later years that brings down the overall total inventory handling capability.

The proposed multimedia universal canister package designs to cover the spectrum of the time-phased repository heat load variation are summarized in Table 7.1-2. Figure 7.1-1 1llustrates the variable package loadings that have been considered to cover the spectrum of heat loads to be accommodated in each of the potential repository media.

The adaptation of the selected loading configurations to cover the time-phased spectrum of the repository heat load distribution is shown for each repository media in Figs. $7.1-2,7.1-3$, and $7.1-4$. In each figure, the reference PRDA burnup inventory heat load distribution has been assumed. With extended burnup, a type A (three-hot-assembly) 
TABLE $7 \cdot 1-2$

REPOSITORY PACKAGE DESIGNS

\begin{tabular}{lccc}
\hline & \multicolumn{1}{c}{$\mathrm{kW} /$ Package } & $\begin{array}{c}\text { Salt } \\
\text { Basalt }\end{array}$ & $\begin{array}{c}\text { Tuff } / \text { Granite } \\
3.3\end{array}$ \\
\hline $\mathrm{A}^{(\mathrm{a})}(2$ assemblies $)$ & & $\mathrm{X}$ & \\
$\mathrm{A} \quad(3$ assemblies $)$ & & $\mathrm{X}$ & $\mathrm{X}$ \\
$\mathrm{B} \quad(2$ assemblies/2 consolidated $)$ & & $\mathrm{X}$ & $\mathrm{X}$ \\
$\mathrm{C} \quad(1$ assembly/4 consolidated $)$ & & $\mathrm{X}$ & $\mathrm{X}$ \\
$\mathrm{D} \quad(6$ consolidated $)$ & $\mathrm{X}$ & $\mathrm{X}$ & $\mathrm{X}$ \\
$\mathrm{E} \quad(8$ consolidated $)$ & $\mathrm{X}$ & & $\mathrm{X}$ \\
\hline
\end{tabular}

(a) Based on extended burnup heat load distribution capability. 


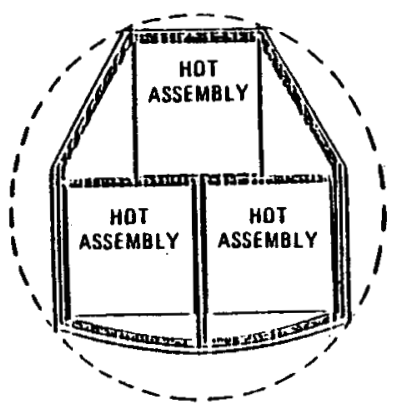

CONFIG A TUFF/GRANITE/BASALT 3 INTACT ASSEMBLIES

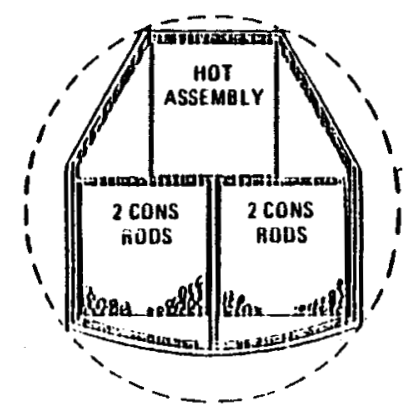

CONFIG C

BASALT/TUFF/GRANITE

ONE INTACT ASSEMBLY

PLUS 4 CONSOLIDATED RODS

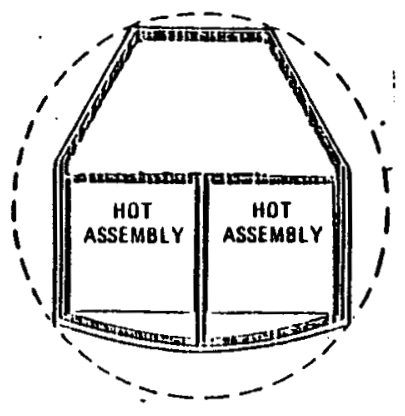

\section{CONFIG A}

BASALT
2 INTACT HOT ASSEMBLIES

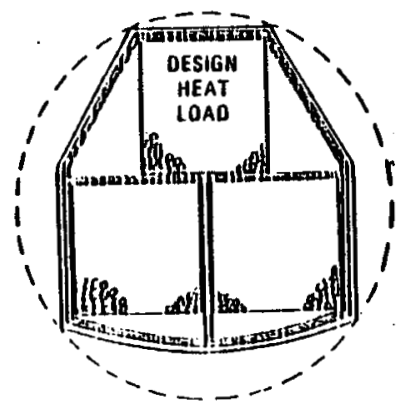

CONFIG D

SALT/BASALT/TUFF/GRANITE 6 CONSOLIDATED RODS

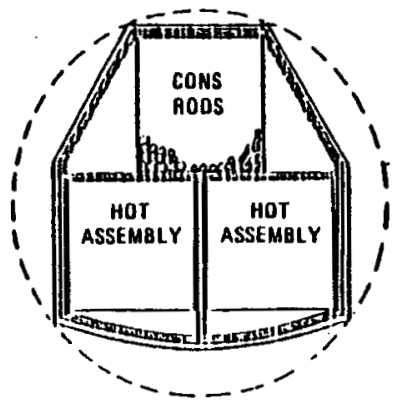
CONFIG B
BASALT/TUFF/GRANITE TWO INTACT ASSEMBLIES PLUS 2 CONSOLIDATED RODS

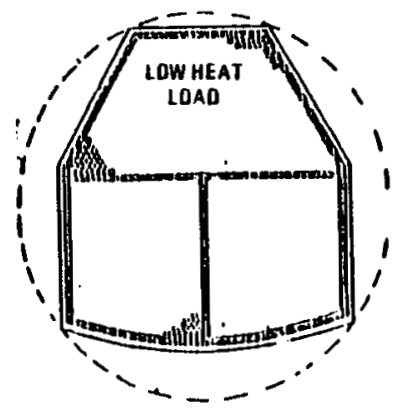

CONFIGE SALT/TUFF/GRANITE 8 CONSOLIDATED RODS

Fig. 7.1-1. Universal canister waste package configurations for multimedia repository application 


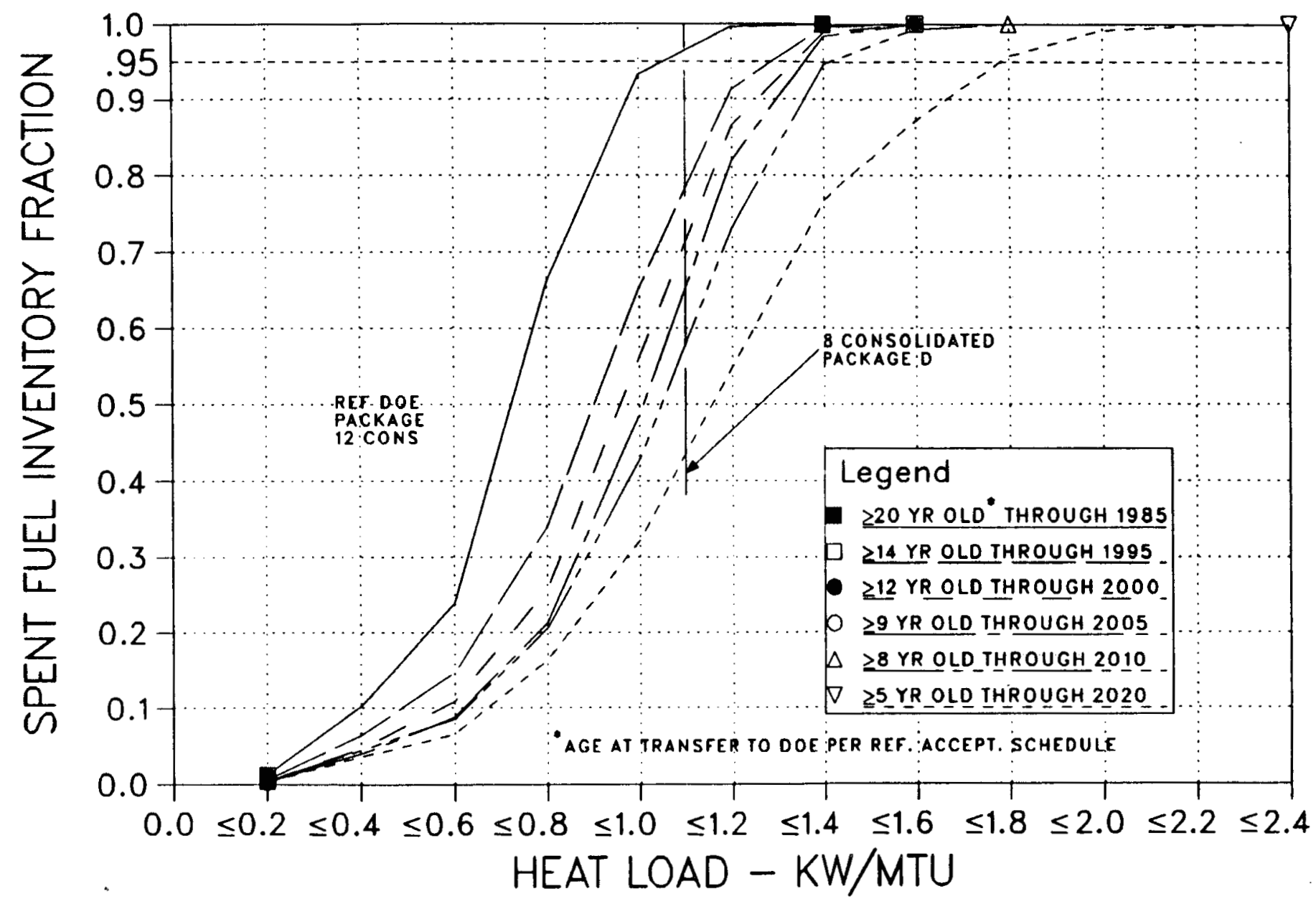

Fig. 7.1-2. Salt repository waste package configuration 


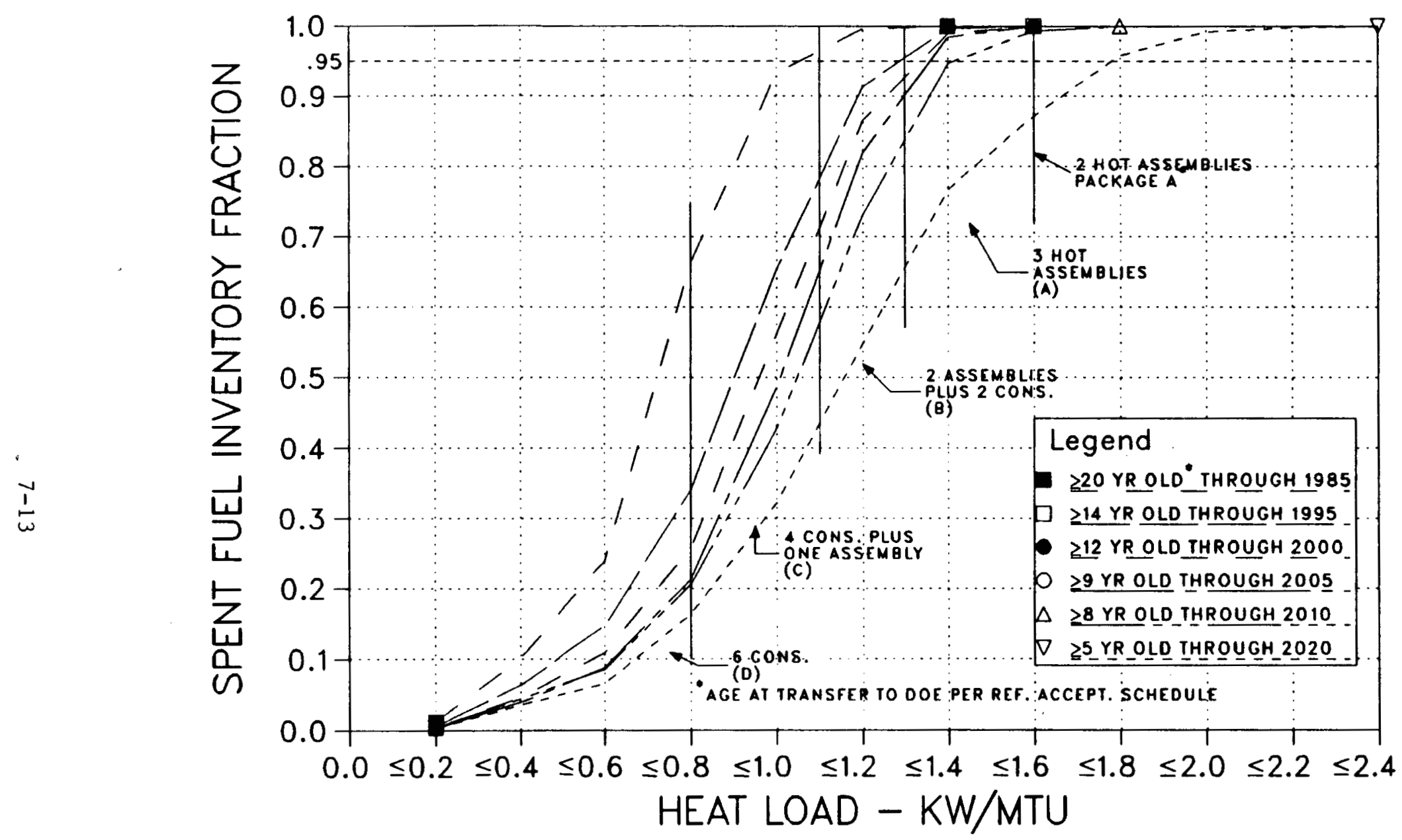

Fig. 7.1-3. Basalt repository waste package configurations 


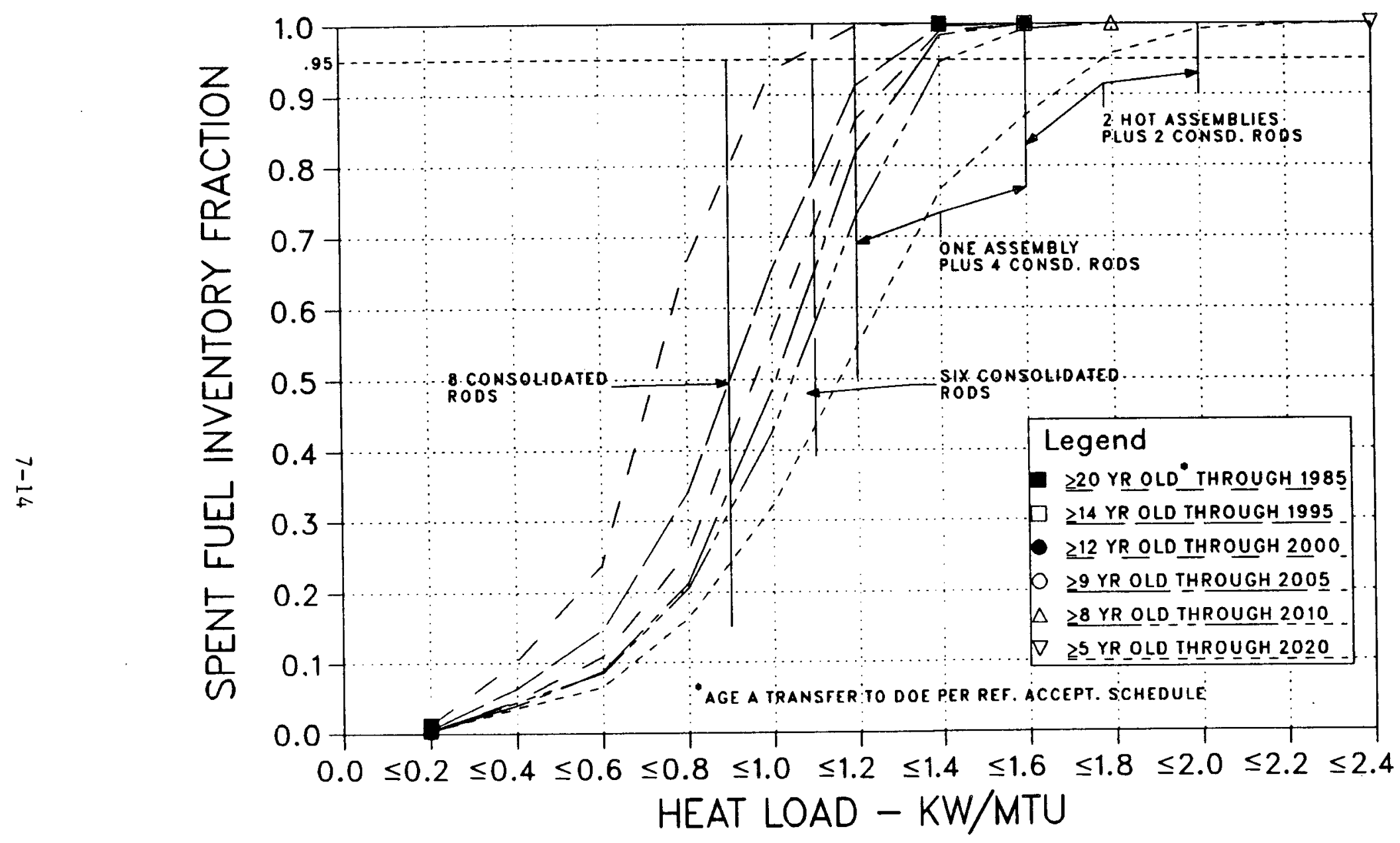

Fig. 7.1-4. Tuff or granite repository waste package configuration 
package would also be utilized in the tuff/granite case at heat loads above about $2 \mathrm{~kW} / \mathrm{MTU}$, and a somewhat higher percentage of rod consolidation would be indicated.

Table 7.1-3 illustrates the package heat load distributions that would be obtained from the time-phased referenced-burnup waste-package designs depicted for the tuff/granite repository as illustrated in Fig. 7.1-4.

The resulting package heat loads, as indicated in Table $7.1-3$, show that very levelized heat loadings over time could be achieved with this concept and that a single package size, at constant pitch, would be very effective for standardizing repository operations and minimizing complexity and costs.

A multi-element universal canister concept with truck and rail transport compatibility, flexible storage mode compatibility (concrete cask or storage module) and multimedia repository waste package compatibility over time is an extremely flexible system. Such a system, when coupled to a transport and storage system with a shielding design and heat load capability for high-burnup, low-aged fuel, results in an extremely flexible high-inventory transfer, storage, and disposal capability system as well.

Such a system can be effectively used with either a contingency or an integrated MRS concept, except that the universal canister system, at full potential and maximum cost effectiveness, requires overpacking to be performed at the repository rather than at an integrated MRS.

In later years of operation, such a universal canister system will yield higher inventory transfer capability from the MRS to the repository at a much lower cask welght than will a system based on shipping overpacked and burnup-1imiting fuel from the integrated MRS. In 
TABLE 7.1-3

PACKAGE HEAT LOAD ILLUSTRATION - TUFF/GRANITE

(3.3 kW/Can Design)

\begin{tabular}{lccccc}
\hline $\begin{array}{c}\text { Range } \\
\text { kW/MTU }\end{array}$ & Type & $\begin{array}{c}\text { No. } \\
\text { Equivalent } \\
\text { Assemblies }\end{array}$ & MTU/Can & $\mathrm{kW} /$ Can & $\begin{array}{c}\text { Inventory Fraction } \\
\text { Through } 2025 \\
\text { Reference Burnup }\end{array}$ \\
\hline 0.2 to 0.9 & E & 8 & 3.7 & 0.74 to 3.3 & $0 \%$ to $25 \%$ \\
0.9 to 1.2 & D & 6 & 2.8 & 2.5 to 3.4 & $26 \%$ to $55 \%$ \\
1.2 to 1.6 & C & 5 & 2.3 & 2.8 to 3.7 & $56 \%$ to $88 \%$ \\
1.6 to 2.0 & B & 4 & 1.8 & 2.9 to 3.6 & $89 \%$ to $100 \%$ \\
2.0 to 2.4 & A & 3 & 1.4 & 2.8 to 3.4 & $\begin{array}{l}\text { Package A only needed } \\
\text { for extended burnup }\end{array}$ \\
\hline
\end{tabular}


addition, media-specific high-heat-load canisters containing hot assemblies would not have to be sent to the MRS with this system.

This latter flexibility could be utilized at any time and could be useful for optimizing the combined MRS and repository operations. For example, if some unscheduled interruption in MRS operations occurred, fuel shipments utilizing hot assemblies could be loaded and sent directly to the repository for disposal until the MRS was fully operational again.

This flexibility would be very useful if the MRS operations were curtailed due to a breakdown of the rod consolidation equipment, for example, or possibly because of some institutional impact such as a changed spent fuel shipping or storage policy by the state in which the MRS was located. In the example of a rod consolidation equipment malfunction, the MRS surge storage capacity would have to be increased unless an efficient alternative, such as that provided by the universal canister concept, were available.

\subsubsection{Concept Maturity}

The canisters and casks used in the GA PRDA study are conceptual designs which have undergone sufficient analysis to strongly suggest that the basic designs could be licensed following a complete and detailed program of analysis. Although such a program would undoubtedly lead to some modification in design details, the basic sizes and capacities of the components should remain unchanged during the course of such an analysis.

Canisters, although of a different shape, have been designed, fabricated, and used at high-temperature gas-cooled reactors (HTGRs) for shipping and storing spent fuel and at LWRs for shipping and disposal of control rods. The cask concepts proposed are similar in design to casks 
that are currently undergoing detailed structural analysis and halfscale model fabrication for near-term testing.

The following subsections describe the key features of the GA canister and cask designs which should ensure the design's qualification for licensing.

7.1.3.1. Spent Fuel Canisters. The principal canister design ( $3 \mathrm{PWR} /$ 6 BWR intact fuel assembly capacity) has undergone sufficient structural analysis to verify its ability to be lifted while containing the maximum load possible (consolidated rods from 6 PWR spent fuel assemblies while the canister is in the mechanical closure configuration, or consolidated rods from 8 PWR spent fuel assemblies in a welded lid configuration). The closure for this canister is provided by a standard top lid design seating on a gasketed surface in the upper flange and locked by seven cam locking devices. The closure locking mechanism was selected to be effective, simple in operation, and inexpensive to manufacture. Further design effort should result in a lid with a central locking mechanism which would allow a little faster in-pool handing.

An impact-limiting skirt is attached to the bottom of this canister to absorb the shocks from normal handling operations. Because the canister does not have to provide containment during transport, it does not need to survive the tests specified in NRC Reg. 10CFR71 or DOT Ref. 49CFR173 for Type A or B nuclear packaging.

Both the principal canister design and the alternate canister design (rail canister with a capacity of 19 PWR or 44 BWR intact fuel assemblies) were included in the analyses for criticality control, thermal performance, and shielding requirements along with the truck and rafl transport casks. The results of these analyses show that both canisters, in conjunction with the transport casks, will meet the performance limits required for these categories of interest. The rall canister was not analyzed structurally because it had been relegated to the 
alternate design status by that stage of the PRDA study. Although it is felt that the rail canister, because of its heavier weight, will be harder to qualify structurally than to the truck canister, this qualification should not be impossible to achieve. In light of the principal canister design results, further strengthening of the rail canister's top and bottom may be necessary to qualify the design from a structural standpoint. Any modifications necessary to meet the structural requirements for the rail canister should not alter its basic design features and capacities.

7.1.3.2. Transport Casks. Both the truck and the rail transport casks used in the PRDA study were designed to survive the hypothetical accident conditions specified for Type B nuclear packages in NRC Reg. 1OCFR71 and DOT Reg. 49CFR 173. The minimum steel wall thickness for the truck cask is 3.0 in., and for the rail cask is 5.0 in. Both cask designs feature built-in fixed-ring impact limiters at the top and bottom of the casks to limit the shock loading due to impact. A 6.0-in.-thick internal impact limiter is mounted between the closure head and the load on these designs protect the closure head and closure bolts from high loads following impact. Both cask designs have a 6.0-in.-thick thermal barrier mounted to the top of the closure head to protect the o-ring seals from excessive temperature during the hypothetical fire.

The truck and rail cask designs have solid steel closure heads which are bolted to the steel cask bodies. The truck cask has a 5.0-in.-thick head while the rail cask's head is 6.0 in. thick. Containment is provided by two concentric 0-ring seals mounted between the casks' heads and bodies.

The shielding analysis for both cask designs used a $50 \%$ margin of safety between calculated values and allowable values of radiation. The allowable values are from DOT Reg. 49 CFR 173 for shipping casks. The casks were assumed to be loaded to capacity with spent fuel in the form 
of consolidated fuel rods from assemblies which are seven years out-ofreactor and which have a burnup value of 40,000 MWd/MTU. For shielding and thermal analysis purposes, this spent fuel is equivalent to five years old and 30,000 MWd/MTU burnup or 10 years old and 55,000 MWd/MTU burnup. For shielding purposes, the minimum wall thickness of the rail cask is $11.1 \mathrm{in}$. of equivalent steel plus $6.2 \mathrm{in}$. of borosilicone neutron shielding. The truck canister has a minimum wall of $10.7 \mathrm{in.}$ of equivalent steel plus 6.0 in. of borosilicone.

Both transport cask designs were analyzed for thermal performance to ensure that the spent fuel cladding temperatures do not exceed $375^{\circ} \mathrm{F}$. As with the shielding analysis, the spent fuel was assumed to be the equivalent of seven years out-of-reactor with 40,000 MWd/MTU burnup. Both casks (and both canisters) qualified thermally for intact assemblies and consolidated rod waste forms.

Both cask and canister designs were analyzed to criticalityallowable limits. All designs have $k_{\text {eff }}$ values of less than 0.92 . For conservativism, no credit was taken for burnup in this analysis. Fresh fuel up to a 1 imit of $3.75 \%$ U-235 initial enrichment can be accommodated in all cask/canister combinations at a $k_{\text {eff }}$ of less than 0.92 .

The truck cask design was held to a loaded weight limit of $75,0001 \mathrm{~b}$ during this study. This 1imit allows $30,0001 \mathrm{~b}$ for a tractor and semitrailer with required tie-down equipment in order to meet a target weight $11 \mathrm{mit}$ of $105,0001 \mathrm{~b}$ (gross vehicle weight) for "routine" overweight truck shipment throughout the United States.

The rail cask is designed to operate at a 100-ton loaded cask limit for loads originating at reactor. For maximum consolidated fuel rod loads originating at an MRS facility, the loaded cask weight can approach 115 tons (versus an allowable welght for this transport leg of 125 to 150 tons). 
The at-reactor storage cask was given the same amount of gamma and neutron shielding as the rafl transport cask. Thermal performance of the storage cask should be better than the rall transport cask because of its homogeneous cask walls (versus a steel/depleted uranium composite cross section in the transport cask) and its larger outer fins. The wall, head, and bottom thicknesses of this cask ensure it of meeting the structural requirements for the storage application.

The costs estimated for the canister and cask designs are based on expected pricing levels from a medium-to-large supplier. Quantity discounts on material and learning curves on labor were applied in cases where large numbers of units are expected to be produced. Material unit costs are based on $\$ / 1 b$ quotations and estimates for similar components.

\subsection{LICENSING FEASIBILITY}

The universal canister is designed to be an integral part of the waste management system and, as such, should not require a specific license from NRC. As a part of the system, the universal canister will be designed to promote safety and minimize contamination during transport, storage, and burial operations.

\subsubsection{Transport from the Reactor}

After the universal canister is loaded with spent fuel assemblies at the reactor, a bolted closure with an elastomer seal is attached. This closure is not intended to be a containment boundary. Thus, the transport cask, efther a truck cask or a rail cask, will provide the containment boundary. Therefore, the universal canister will not require licensing as a part of the transport system used to move spent fuel assemblies from the reactors. 


\subsubsection{Storage at an MRS Facility}

Some or all of the spent fuel may be stored at an MRS facility prior to transport to a repository for final burial. When this is the case, the universal canister will be removed from the transport cask and permanently sealed with a welded closure before being placed in a concrete storage silo. The universal canister now serves as a containment boundary and as such will perform a safety function in the storage system which must comply with regulatory requirements. The conceptual design features of the universal canister will comply with the current regulatory requirements for adequate safety at an independent spent fuel storage facility.

\subsubsection{Transport from the MRS Facility}

A11 the universal canisters will have a welded closure added at the MRS facility, and this can qualify as a containment boundary during transport. The design of the transport cask will determine whether or not the universal canister will be a certified component of the transportation package. It may be desirable to design the transport cask so that the universal canister does not provide a containment function. This would limit the amount of inspection and testing required for the canister and would increase the requirements for the transport cask. Future studies will be required to determine the better method of compliance with regulations.

\subsubsection{Burial at the Repository}

Each of the host media (tuff, granite, basalt, or salt) may have varying requirements for the waste burial package. The universal canister could be an integral component of the required waste burial package and perhaps could satisfy all of the requirements itself for some media form. 
Conceptual design features of the universal canister can comply with the anticipated requirements for a waste burial package for the case when the canister is used alone as well as when the canister is used as a component of a waste burial package. Inspection and testing requirements are expected to vary, depending on the function of the universal canister when used as a part of the burial package or as the burial package.

\subsection{ENVIRONMENTAL FEASIBILITY}

The use of a universal canister has definite environmental advantages which increase the CRWM system feasibility. Although the canister is not a safety requirement, providing a container around the radioactively contaminated spent fuel at the source of this fuel reduces the risk of contamination spread in the different elements of the system. This reduces the generation of secondary low-level radioactive wastes in the overall system and hence reduces the environmental impact of the CRWM system. The following sections evaluate the various environmental impact areas.

\subsubsection{Resource Commitments}

Negligible additional resources would be committed as a result of the introduction of the universal canister. The canisters would be manufactured at existing metal fabricators' facilities and would not commit any additional land or water. The material and energy usage would depend on the number of canisters required and would be partially offset by elimination of other components which could be replaced by the canister. These components include complex internal baskets in storage and shipping casks and internal baskets or canisters which may be required in the final waste package. 


\subsubsection{Nonradiological Effluents}

The use of the universal canister adds no nonradioactive pollutants to the environment, either chemical or thermal. By reducing the contamination level of the CRWM system components, a small reduction in chemical pollutant released may be realized from reduced use of cleaning and decon agents.

\subsubsection{Radiological Effects}

Beneficial radiological impacts result from the use of the universal canister. By placing the spent fuel in a canister at its source, control of radioactive contamination is enhanced throughout the CRWM system.

Because of the high level of radiation emitted from the spent fuel, the CRWM system requires many complex remote systems for handling, shipping, and packaging. Minimizing the contamination of these systems will make their maintenance and repair much easier, or in some cases, possible. Reduction in decontamination of equipment and facilities also reduces secondary low-level radioactive wastes.

Since the universal canister eventually becomes the internal canister in the waste package, its disposal does not impose any additional requirements on the system, even though it may have become activated during its lifetime.

\subsubsection{Ecological Effects}

There are no ecological effects on plant and wildlife due to the use of the universal canister. The use of the canister does not have either a positive or a negative impact on the ecological system. 


\subsection{SOCIOECONOMIC FEASIBILITY}

The use of the universal canister is socioeconomically feasible since there is no socioeconomic impact and the canister does not increase labor or local community service requirements. The number of canisters required can easily be produced within the existing manufacturing capability. Once specified, the canisters can be manufactured by several companies within the U.S.

\subsection{REFERENCE}

7-1. McLeod, N. B., Y. M. Park, T. D. Nguyen, D. W. Tonkay, and S. Katsenelenbogen, "Preliminary Feasibility Assessment of Variable Repository Disposal Package Loadings of Spent Nuclear Fuel," NUS-4607, September 1984. 


\section{EVALUATION OF THE SELF-SHIELDED WASTE PACKAGE}

The Universal Self-Shielded Waste Package (USSWP) was evaluated to determine how this concept compared with the universal canister concept. The USSWP concept was developed by Westinghouse and TVA and is described in their PRDA draft report (Ref. 8-1). The approach used was to evaluate the technical feasibility of the USSWP, compare the elements of the total system cost to determine where these differed greatly between the universal canister and the USSWP, and examine those elements in greater detail. The technical feasibility evaluated the shielding and thermal analysis of USSWP as this related to its inventory handling capability, while the economic feasibility examined the USSWP unit cost and the MRS costs. The transportation costs were in reasonable agreement with the universal canister study and the repository costs were questioned but not evaluated in detail.

The results of the evaluation indicate that the USSWP system is very sensitive to the unit cost of the USSWP and that this cost is known with little certainty. The concept is technically feasible for storage and transportation, but it (1) requires modification to reduce the neutron dose rate and (2) may require derating for the higher burnup and less cooled spent fuel. Its feasibility as a disposal package is questioned because of the high heat load. Further evaluation is required by the repository designers to establish this feasibility. Licensing is of concern, since there are three separate regulations which must be satisfied with the same hardware. 


\subsection{BASES FOR THE USSWP EVALUATION}

To limit the scope of the evaluation, the following bases and assumptions were made:

1. The PRDA alternate case was assumed as defined in Ref. 8-2, with the integrated MRS in 1996 and no repository delay. Table 2 of Ref. 8-2 was assumed for the waste acceptance schedule.

2. Only one Westinghouse concept was evaluated, the USSWP.

3. The salt/tuff repository assumed by Westinghouse is the same as the salt/granite repository analyzed by GA.

4. The spent fuel assemblies are shlpped from the reactors to the MRS with the reference PRDA transportation system defined in Ref. 8-2.

5. The spent fuel is consolidated at the MRS and placed into canisters which are compatible with the USSWP.

6. The USSWP enters the system at the MRS and is loaded with consolidated fuel canisters.

1

\subsection{TECHNICAL REVIEW OF USSWP}

A preliminary assessment of the thermal and shielding design to assess the resulting inventory handling capability of the Westinghouse USSWP cask has been completed. The detailed inventory handling capability of systems designed to various design bases, as a combination of the fuel burnup and age distribution, was contained in Section 2, Volume 1 of GA's draft report (Ref, 8-3). This assessment utilized those results along with the results of both GA and Westinghouse shielding analyses 
for the USSWP cask to arrive at an overall estimate of the USSWP cask .inventory handling capability over time.

\subsubsection{Shielding Analysis Results}

The design basis used by Westinghouse for shielding calculations for the USSWP cask was 10-year decay of consolidated fuel exposed to 33,000 MWd/MTU burnup. Given the PRDA reference case acceptance schedule, a transport or storage cask system which just meets the dose rate limits based on this design basis will have an overall inventory handling capability of only $50 \%$ of the entire LWR fuel inventory to be handled through the year 2025, as was discussed in Section 2 of Ref. 8-3. A system, with a design basis equivalent to a capability for handling seven-year-old spent fuel of $40,000 \mathrm{MWd} / \mathrm{MTU}$ burnup, is required if a $95 \%$ inventory handling capability is to be achieved. Table 8.2-1 summarizes the dose rate estimates by Westinghouse (Ref. 8-4) for their design basis as well as estimates by GA for both the 10-year/33,000 and the seven-year/40,000 MWd/MTU design basis. The actual GA calculations were performed for assembly, rather than consolidated rod loadings. Dose rates for consolidated rod loadings were assumed to be a factor of two higher than the calculated rates with assembly loadings. The GA results in Table $8.2-1$ have been corrected to reflect consolidated rod loadings.

From these results, it is seen that the GA and Westinghouse dose estimates of cask surface dose are in basic agreement to within about $20 \%$, and both estimates confirm that additional neutron shielding will be required for the USSWP cask even for the reference design basis of 33,000 MWd/MTU and 10-year cooling. If the GA estimates of the ratio of the dose at $2 \mathrm{~m}$ to the surface dose are correct and $4 \mathrm{mR} / \mathrm{h}$ of the Westinghouse surface dose is due to gammas, then the actual gamma dose at $2 \mathrm{~m}$ would be expected to be 1.5 to $2.0 \mathrm{mR} / \mathrm{h}$. 
TABLE 8.2-1

UNIVERSAL SELF-SHIELDED WASTE PACKAGE(a) DOSE CALCULATION RESULTS (mrem/h)

\begin{tabular}{|c|c|c|c|c|c|}
\hline & \multicolumn{2}{|c|}{$\begin{array}{l}\text { 33,000 MWd/MTU/ } \\
\text { 10-Year Cooled }\end{array}$} & \multirow{2}{*}{$\begin{array}{c}40,000 \mathrm{MWd} / \mathrm{MTU} / \\
7 \text {-Year Cooled }\end{array}$} & \multicolumn{2}{|l|}{ Allowable } \\
\hline & Westinghouse & GA & & Transportation & Store \\
\hline \multicolumn{6}{|c|}{ Cask surface } \\
\hline \multirow{3}{*}{$\begin{array}{l}\text { Neutron } \\
\text { Gamma }\end{array}$} & 83 & 72 & 204 & & \\
\hline & 4 & 4 & 13 & & \\
\hline & 87 & 76 & $\overline{218}$ & 200 & $20^{(c)}$ \\
\hline \multicolumn{6}{|c|}{$2 \mathrm{~m}$ from cask } \\
\hline \multirow{3}{*}{$\begin{array}{l}\text { Neutron } \\
\text { Gamma }(b)\end{array}$} & Not calculated & 51 & 143 & & \\
\hline & Not ccalculated & 2 & 7 & & \\
\hline & & 53 & 150 & 10 & N/A \\
\hline
\end{tabular}

(a) Nodular cast iron, $40 \mathrm{~cm}$ thick, 3.7 w/o carbon, 18 consolidated PWR assemblies.

(b) Estimated, mainly from capture gammas from neutron capture in cast iron.

(c) The design basis for concrete storage cask. 
The additional neutron shielding would have to attenuate the GA estimate neutron dose at $2 \mathrm{~m}$ to where the total dose would be $10 \mathrm{mR} / \mathrm{h}$ or less, i.e., the neutron dose at $2 \mathrm{~m}$ must be reduced to about $8 \mathrm{mR} / \mathrm{h}$. For the reference design basis this would require a neutron dose rate reduction factor of seven. A reduction of the cask surface dose to $20 \mathrm{mR} / \mathrm{h}$ for storage (Ref. 8-5) requires a neutron reduction factor of 4.5 .

For a 40,000 MWd/MTU seven-year decay design basis assumption, the neutron shielding design would be further complicated by the fact that the neutron capture gamma dose as well as the direct neutron dose would increase by about a factor of three, or in direct proportion to the much higher neutron source for such hotter fuels.

Assuming that $\sim 2 \mathrm{mR} / \mathrm{h}$ of the 2 to $3 \mathrm{mR} / \mathrm{h}$ of gamma dose at $2 \mathrm{~m}$ is due to capture gammas for the reference fuel, the capture gamma source at $2 \mathrm{~m}$ for the hotter fuel would be 6 to $7 \mathrm{mR} / \mathrm{h}$ and the allowable neutron dose would be reduced to 3 to $4 \mathrm{mR} / \mathrm{h}$. Thus the estimated source of $144 \mathrm{mR} / \mathrm{h}$ due to neutrons for the 40,000 MWd/MTU seven-year fuel would have to be attenuated by a factor of about 40 or more. A reduction of the cask surface dose from 28 to $20 \mathrm{mR} / \mathrm{h}$ for storage requires a neutron reduction factor of 30 .

The additional neutron shielding thickness required is estimated to be about $7.6 \mathrm{~cm}$ for the reference design basis fuel and about $14 \mathrm{~cm}$ for the higher design basis fuel. Some additional gamma shielding or an increase in the thickness of the cask wall may be required for fuel that is hotter than that assumed in the reference design basis.

From a storage standpoint, the expected cask surface dose rates of $87 \mathrm{mR} / \mathrm{h}$ and $218 \mathrm{mR} / \mathrm{h}$ are, in CA's opinion, too high and do not meet the intent of ALARA as proposed in Ref. 8-6. With a storage area containing over 2000 casks, inspection maintenance and retrieval may become a problem. 


\subsubsection{Therma1 Analysis Review}

No thermal analysis results were calculated by GA for the USSWP cask design. A review of the thermal analysis results given in the Westinghouse report ( $\operatorname{Ref}, 8-1$ ) was made to review the margins of the current design so that an estimate of the potential inventory handling capability could be made in light of the cask thermal design limitations. This review was limited to that of the USSWP package in the salt repository and in the tuff repository as discussed in Appendix $F$ of the Westinghouse report. USSWP has no problem with storage and transportation, since expected fuel clad temperatures during storage and transportation are expected to be less than $375^{\circ} \mathrm{C}$ for the entire inventory.

Figures $F-2$ and $F-3$ in the Westinghouse report show the thermal analysis model used and the temperature results obtained for reference design basis fuel in a salt repository. The temperature results show a $52^{\circ} \mathrm{C}$ margin to the assumed 1 imit of $375^{\circ} \mathrm{C}$ for the reference fuel basis in the salt repository. Very approximate estimates indicate that the heat load could be increased by $\sim 50 \%$ or to a value of $\sim 1.6$ to $1.7 \mathrm{~kW} / \mathrm{MTU}$ before the limiting temperature is reached. This would result in a $90 \%$ inventory capability in salt as shown in Fig. 8.2-1. It would also appear likely that heat loads of $1.8 \mathrm{~kW} / \mathrm{MTU}$ or greater, corresponding to that for 40,000 MWd/MTU seven-year decayed fue1, could be accommodated by removing the fuel in the central region, $i . e .$, by a reducing the cask fuel load of $11 \%$.

The USSWP cask thermal design characteristics are such that there is little or no margin to the temperature limit for reference fuel placed in a tuff repository. Some modest margin could be gained if tunnel backfilling were delayed by 50 years and/or if certain internal design modifications were carried out. If necessary, the central compartment could be filled with compacted nonfuel-bearing components resulting from the fuel consolidation step. 


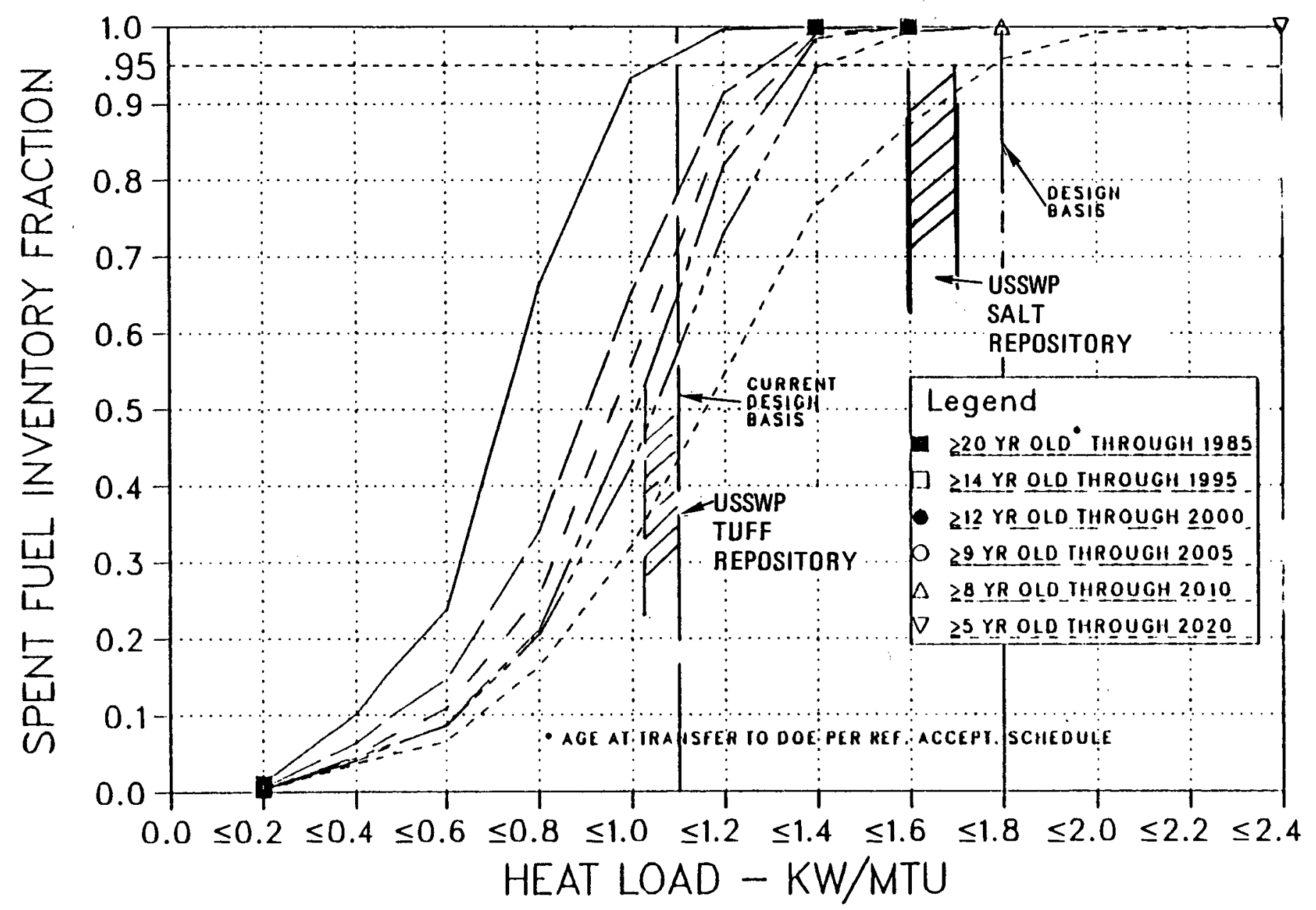

Fig. 8.2-1. Heat load distribution for reference fuel burnup 


\subsubsection{Inventory Handling Capability}

The time-phased inventory distribution of the spent fuel heat load and neutron dose is shown in Figs. $8.2-1$ and $8.2-3$, respectively, consistent with the burnup and age distribution expected at the time of transfer to a repository (or MRS) with a 1998 startup date based on the reference fuel acceptance schedule. An earlier 1996 startup date would typically result in a few percent reduction in the cummulative inventory fraction that is below a given heat load or neutron dose.

As may be noted, systems which just meet the neutron shielding and heat 1oad constraints for reference fuel can handle $70 \%$ to $75 \%$ of a11 fuel from discharges through the year 2000 that would be transferred by the year $(2000+12)=2012$, for example. The total handling capability of all fuel to be discharged through the year 2020 is about $50 \%$, as indicated on Figs. 8.2-1 and 8.2-2. Systems designed to meet the inventory-imposed contraints of $40,000 \mathrm{MWd} / \mathrm{MTU}$ and seven-year cooled fuel will have an overall inventory handling capability of $\geq 95 \%$ as indicated.

In summary, the thermal design of the USSWP cask will allow about a $50 \%$ inventory disposal capability in the tuff repository or about $90 \%$ disposal capability in a salt repository. For one repository of each type, the overall inventory capability from a thermal design standpoint is $~ 70 \%$ and removal of fuel from the central canister would probably increase the overall disposal capability to about $80 \%$ to $90 \%$.

From a shielding design standpoint, the current USSWP is not adequate without some provision for added neutron shielding around the cask. With nominal added shielding for both transport and storage modes, the overall inventory capability is about $50 \%$. A high inventory handling capability w11l require thicker neutron shielding and most probably a thicker and heavier cask. 


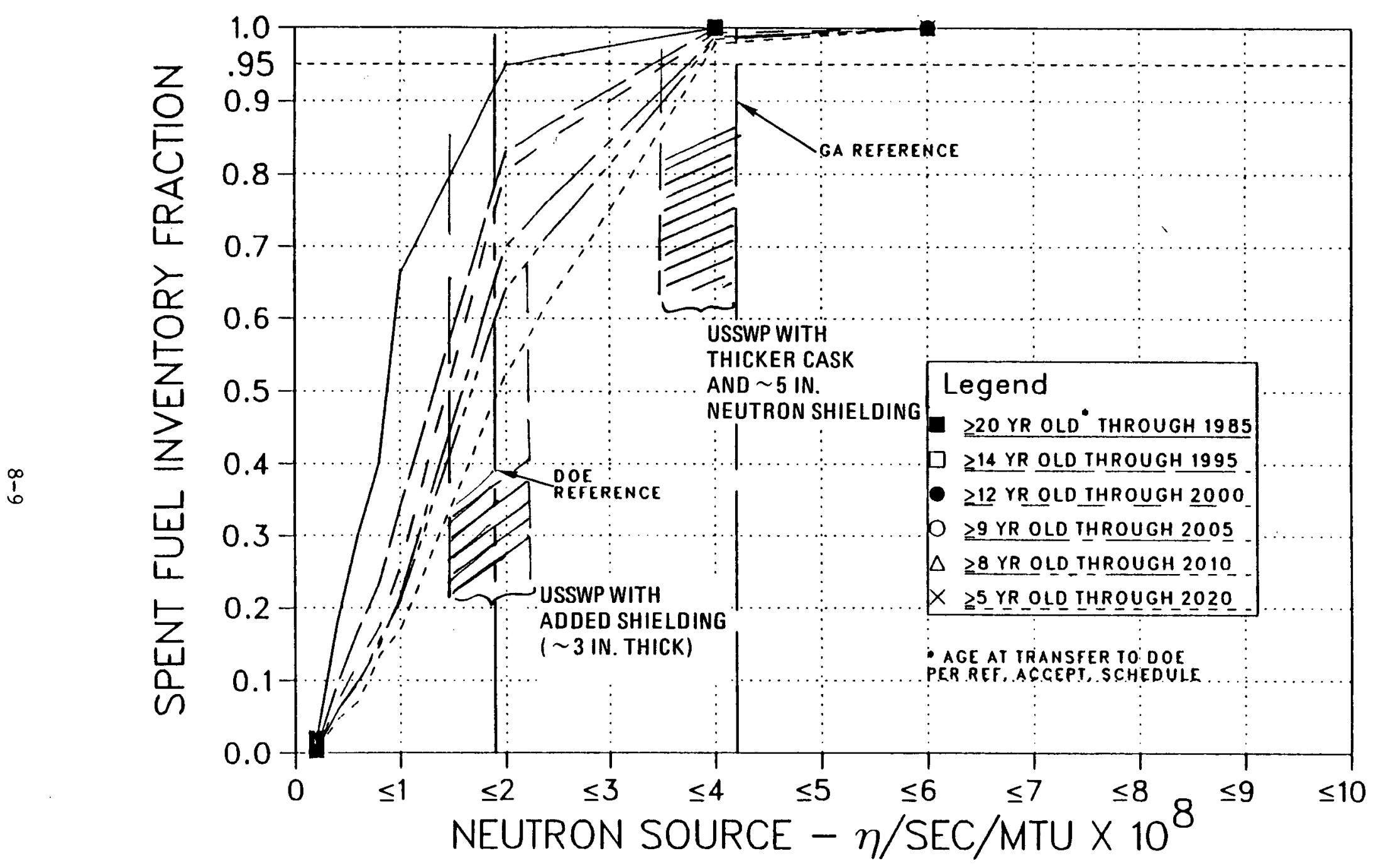

Fig. 8.2-2. Neutron source distribution for reference fuel burnup 


\subsection{LICENSING OF USSWP}

\subsubsection{Storage and Transportation}

The storage and shipment of spent fuel are covered by NRC regulations found primarily in 10CFR71 and 10CFR72. Also, transportation of radioactive material is regulated by DOT through 49CFR, particularly Part 173, "Shippers - General Requirements for Shipments and Packagings." The NRC and DOT requirements are in many cases identical, but where differences exist, the more restrictive requirements must be met. These regulations have been reviewed to Identify licensing issues related to the multi-use cask concept. Two issues were found which could result in problems during licensing or subsequently when the storage cask becomes a shipping cask.

A licensing consideration for dual-purpose casks is the extent to which NRC and DOT will require the casks to be inspected prior to shipment. Both DOT and NRC require that the cask seals be verified to be "properly installed, secured and free of defects" before shipping. In newly sealed casks this should not present a problem, but what will be the inspection requirements for casks which are left in storage for long periods of time (e.g., 20 years)? Will all the casks have to be opened to inspect the seals, will opening a selected few be sufficient, or will external inspection be acceptable? Also, will internal features of the cask require inspection?

A second consideration is the length of time the cask license is valid. 10CFR72 allows NRC storage licenses for up to 20 years, whereas internal NRC practice has been to give transport cask licenses for only five years. As a result, while a licensed dual-purpose cask is sitting in storage, DOE runs the risk of not being able to renew the transportation license once it expires, or DOE may be required to perform a retrofit upgrade to satisfy new regulations before the cask can be used for shipping. 
The use of casks for the dual purposes of transportation and storage is not precluded by regulation, and there appear to be no insurmountable technical problems which would prevent the development of a design which can satisfy the requirements for both transportation and storage. Because dual-purpose casks must meet two sets of requirements, it is anticipated that dual-purpose casks w111 be more expensive than casks suitable for storage only.

\subsubsection{Disposal}

The design criteria for the disposal waste package are given in 10CFR60. Confirmation that the USSWP meets these criteria will be done during final closure at the repository. This leads to two areas of uncertainty for the USSWP as a disposal waste package; the design criterla can change in the next 12 years and verffication methods have not been defined by NRC to qualify the package for disposal.

\subsection{USSWP COST ESTIMATE}

A comparison was made between the costs estimated to fabricate USSWP's by Westinghouse and those same costs estimated by the GA cost estimating function. This comparison uses the Westinghouse Study Case 12 conditions which have the following features:

- DOE alternate scenario.

- Dry spent fuel storage at reactor.

- Spent fuel shipped intact to MRS.

- Integrated MRS consolidates and packages for burial (1966 startup). 


\subsubsection{Cost of Unmodified USSWP}

The USSWP's are assumed to be fabricated of nodular graphite cast iron. The GA cost estimates are presented using the same cost categories used by Westinghouse in its cost estimate (Table 8.4-1) and are for the same cask design. Modifications to the cask are discussed in Section 8.4.2.

Because of the relatively large size and heavy weight of the USSWP, existing facilities capable of fabricating it are not numerous, and the heavy equipment needed for efficient, large-scale production of this cask is generally not now in place. Current operators of facilities large enough to fabricate the USSWP are reluctant to quote on estimated costs without more detalled information than is avallable for this study.

The GA cost estimate is presented in the form of a range of costs, from "low" through "expected" to "high." A summary of these cost estimates is presented in Table 8.4-2 along with the Westinghouse cost estimate for the case examined. This case introduces the USSWP at the MRS. The total costs do not include shipment of the finished waste packages from the fabricator's shop nor installation of the shield/seal plug at the repository. Backup for the GA cost estimates is included in Appendix E.

The GA cost estimates for fabrication of the USSWP are significantly higher than those estimated by Westinghouse. The GA "low" estimate is 1.5 times greater than the Westinghouse figure. The GA "expected" value is slightly more than double the Westinghouse estimate. The GA "high" estimate is 2.6 times greater than the Westinghouse figure.

Because of the large number of casks required for Study Case 12, the system is relatively sensitive to changes in fabrication costs 
TABLE $8 \cdot 4-1$

WESTINGHOUSE COST ESTIMATE FOR USSWP FOR INTRODUCTION AT THE MRS (1985 Dollars)

Main body casting $(141,0001 \mathrm{~b} \times \$ 0.50 / 1 \mathrm{~b})$

70,500

Casting material certification ( $32 \mathrm{~h} \times \$ 85 / \mathrm{h})$

2,700

Ship casting to machine shop, 100 miles ( $\$ 800$ shipping,

1,400

\$600 loading/unloading)

Machine main body, inspect ( $120 \mathrm{~h} \times \$ 75 / \mathrm{h})$

9,000

Paint exterior of main body ( $24 \mathrm{~h} \times \$ 60 / \mathrm{h})$

1,500

Volumetric inspection (u1trasonic) ( $24 \mathrm{~h} \times \$ 100 / \mathrm{h})$

2,400

Bolted closure lids (2)

14,000

Internal basket (carbon steel heat transfer grid, stainless

16,000 steel cans to handle consolidated fuel rods, no neutron absorber) (average of PWR and BWR baskets)

Trunnions, closure lid seals

6,000

Bolts, studs, nuts

1,000

Handling at machine shop ( $16 \mathrm{~h} \times \$ 65 / \mathrm{h})$

1,000

Subtotal

125,500

Contingency (20\%)

25,100

Subtotal

150,600

G\&A (12\%)

18,100

Subtotal

168,700

Markup (15\%)

25,300

Subtotal

194,000

Owner's procurement cost (4\%)

7,800

Subtotal

201,800

Ship finished cask 750 miles $(158,000 \times \$ 7.33 / 1001$ b)

11,600

Total

$213,400^{(a)}$

Shield/seal plug installed at repository

6,100

\footnotetext{
(a) Use previous estimate of $\$ 215,000$.
} 
TABLE $8.4-2$

UNIVERSAL SELF-SHIELDED WASTE PACKAGE CASK COST

SUMMARY - SSP-9 DESIGN

(1985 Dollars)

\begin{tabular}{|c|c|c|c|c|}
\hline \multirow[b]{2}{*}{ Description } & \multirow{2}{*}{$\begin{array}{c}\text { WTSD } \\
\text { Estimate }\end{array}$} & \multicolumn{3}{|c|}{ GA Estimate Range } \\
\hline & & Low & High & Expected \\
\hline Main body casting & 70,500 & 115,500 & 192,500 & 154,000 \\
\hline Casting material certificate & 2,700 & 3,400 & 10,200 & 5,100 \\
\hline Ship casting 100 miles & 1,400 & 3,300 & 4,100 & 3,500 \\
\hline Machine body Insert & 9,000 & 9,400 & 23,800 & 15,000 \\
\hline Paint body & 1,500 & 1,400 & 3,300 & 2,600 \\
\hline Ultrasonic inspection & 2,400 & 2,000 & 6,000 & 4,000 \\
\hline Bolted closure lids (2) & 14,000 & 22,700 & 43,400 & 32,800 \\
\hline Internal basket & 16,000 & 16,000 & 32,000 & 24,000 \\
\hline Trunnion seals & 6,000 & 6,000 & 8,500 & 7,500 \\
\hline Bolts, studs, nuts & 1,000 & 1,000 & 3,000 & 2,000 \\
\hline Handling at machine ship & 1,000 & 700 & 2,600 & 2,000 \\
\hline Subtotal & 125,500 & 181,400 & 329,400 & 252,500 \\
\hline Contingency (20\%) & 25,100 & 36,280 & 65,880 & 50,500 \\
\hline G\&A $(12 \%)$ & 18,072 & 26,122 & 47,434 & 36,360 \\
\hline Mark-up (15\%) & 25,301 & 36,570 & 66,407 & 50,904 \\
\hline Owner's procurement $(4 \%)$ & 7,759 & 11,215 & 20,365 & 15,611 \\
\hline Total & 201,732 & 291,587 & 529,485 & 405,875 \\
\hline
\end{tabular}


for each unit. Although this case is not shown graphically in the Westinghouse report (Ref. 8-1), the relative sensitivity appears to be similar to the curves shown for Scenarios 2 and 3 on Fig. 8.4-1 taken from the Westinghouse report. It can be seen from this figure that the total system cost uncertainty with USSWP is very large. The GA range of estimates is based on commercial quality assurance requirements. It is our opinion that the requirements to be imposed by NRC to meet storage, transportation, and disposal could increase USSWP unit costs further to $\$ 600,000$ to $\$ 800,000$.

\subsubsection{Adjustment for Neutron Shielding}

As discussed in Section 8.2, additional neutron shielding is necessary for the USSWP before it can be used as a transportation cask, and additional neutron shielding was also suggested if it were going to be used as a storage cask. Of the $\sim 15,000$ casks required for Case 12, 2570 casks are needed to store the 21,300 MTU which will accummulate at the MRS. In addition, approximately 200 casks could be in transit to the repository. If a system can be devised to allow temporary use of an additional neutron shield, approximately 3000 shield units would be required.

Assuming a simple wrap-around design for the shield units using a borosilicate material, the cost of the unit would be approximately the cost of the borosilicate. This material is estimated to cost $\$ 5.75 / 1 \mathrm{~b}$, resulting in a cost of $\$ 60,000$ for a $7.6-\mathrm{cm}$-thick unit and $\$ 114,000$ for a 14-cm-thick unit. Therefore the added cost to the CRWM system would be from $\$ 23$ million to $\$ 345$ million, depending on the final requirements for storage. 


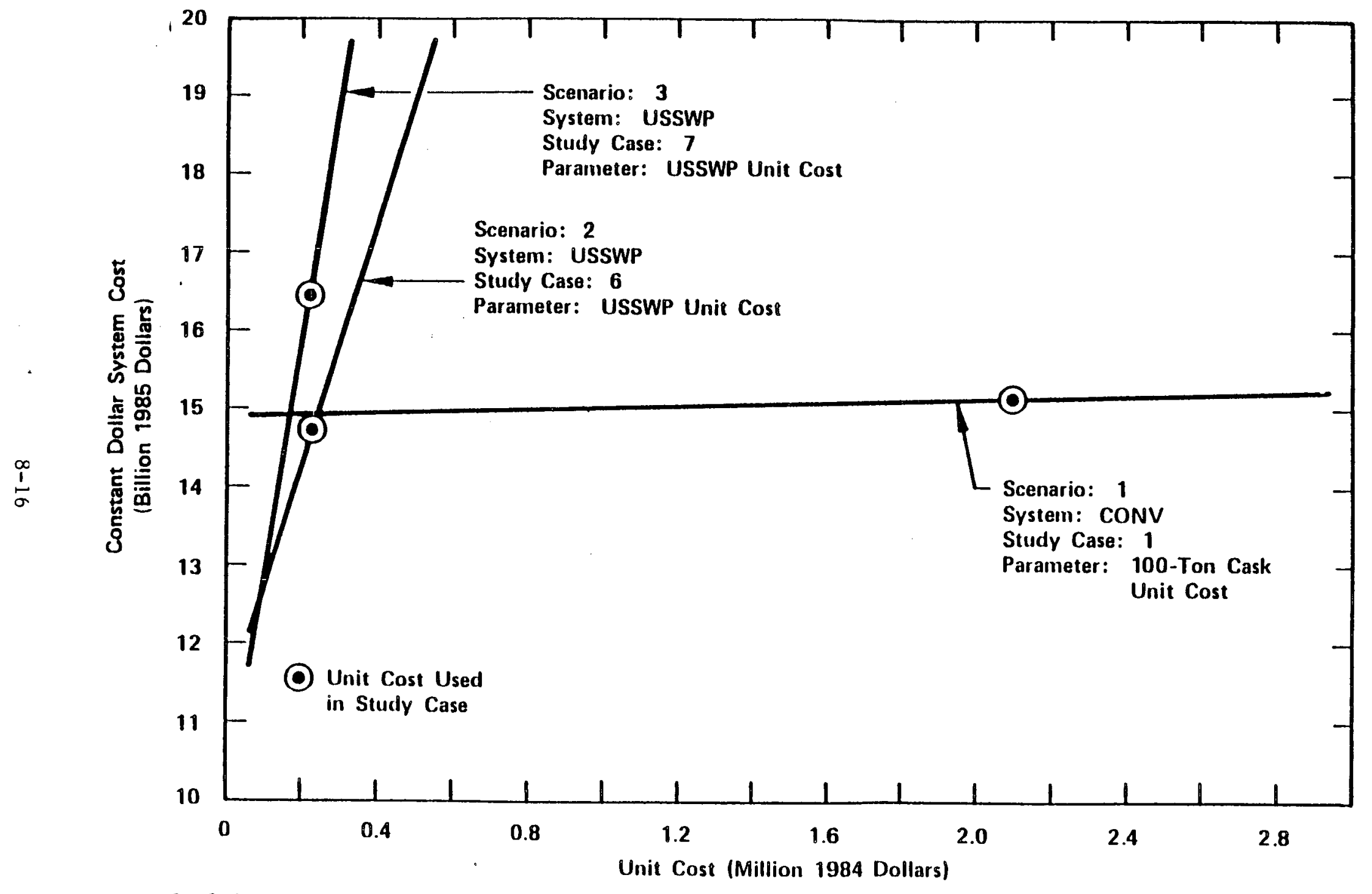

Ref. 8-1

Fig. 8.4-1. Single-parameter sensitivity for cask unit cost versus system cost for USSWP system 
8.5. TOTAL SYSTEM COSTS

8.5.1. Cost Element Comparison

A comparison of the total system costs was made for both the universal canister and the universal self-shielded waste package to determine any major difference in the cost elements and to select cost elements for detailed examination. Table 8.5-1 compares nine cost elements which could be extracted from GA and the Westinghouse reports. Westinghouse's Case 12 (Ref. 8-1 Table E-1) was used for this comparison. The following can be concluded from this table:

1. The Westinghouse transportation costs appear to be reasonable. An estimated split between items 1 and 7 was made based on relative cask capacities. $\$ 10$ to $\$ 20$ million, however, were added in item 6, transportation capital cost, to cover the cost of providing personnel barriers with neutron shielding as required to meet transportation regulations.

2. The MRS costs were evaluated in more detail because of an apparent one billion dollar difference in operating costs. This evaluation is discussed further in Section 8.6 .1 , MRS Cost Estimates. The Westinghouse estimate assumes a constant $\$ 25$ to $\$ 26$ million per year operating costs, which is considerably lower than the other PRDA contractors and which does not vary with the facility throughput.

3. USSWP costs of $\$ 3.31$ billion are very sensitive to the cost of the package as shown by the GA high and low cases. Also the total CRWM system costs are very sensitive to the USSWP costs. For Case 12, 24\% of the CRWM costs are due to the USSWP. This increases to $45 \%$ for the GA high case. This sensitivity is shown in Fig. 8.5-1. 
TABLE 8.5-1

PRDA ALTERNATE CASE TOTAL SYSTEM COST COMPARISONS (Billion Undiscounted 1985 Dollars)

\begin{tabular}{|c|c|c|c|c|c|c|}
\hline & & $\begin{array}{l}\text { Universa1 } \\
\text { Canister }\end{array}$ & $\begin{array}{c}\text { USSWP } \\
\text { (Case 12) }\end{array}$ & $\begin{array}{l}\text { USSWP } \\
\text { (GA Low) }\end{array}$ & $\begin{array}{c}\text { USSWP } \\
\text { (GA High) }\end{array}$ & $\begin{array}{c}\text { USSWP } \\
\text { Maximum }\end{array}$ \\
\hline & USSWP unit cost $(\$ 000)$ & & 202.00 & 292.00 & 530.00 & 800.00 \\
\hline 1 . & Reactor-to-MRS transportation & 0.72 & 1.00 & Case 12 & Case 12 & Case 12 \\
\hline 2. & MRS capital/decommissioning cost & 0.37 & 0.32 & Case 12 & Case 12 & Case 12 \\
\hline 3 . & MRS operating cost & 1.80 & 0.81 & (a) & (a) & \\
\hline 4. & Canisters/casks & 0.23 & 3.31 & 4.78 & 8.69 & 13.12 \\
\hline & Storage cask modifications & N/A & 0.00 & 0.02 & 0.35 & 0.35 \\
\hline 6. & MRS-to-repository transportation capital & 0.08 & (In No. 6) & 0.01 & 0.02 & 0.02 \\
\hline 7. & MRS-to-repository transportation operation & 0.37 & 0.53 & Case 12 & Case 12 & Case 12 \\
\hline & Emplacement packaging & 3.05 & (In No. 9) & (a) & (a) & \\
\hline 9. & Repository & 9.27 & 8.11 & (a) & (a) & \\
\hline & Total CRWM system & 15.89 & 14.08 & 15.58 & 19.83 & 24.26 \\
\hline & At-reactor storage & 0.19 & 0.26 & Case 12 & Case 12 & Case 12 \\
\hline & Total & 16.08 & 14.34 & 15.84 & 20.09 & 24.52 \\
\hline
\end{tabular}

\footnotetext{
${ }^{\text {(a) }}$ Case 12 costs not evaluated in detal1, but appear low.
} 


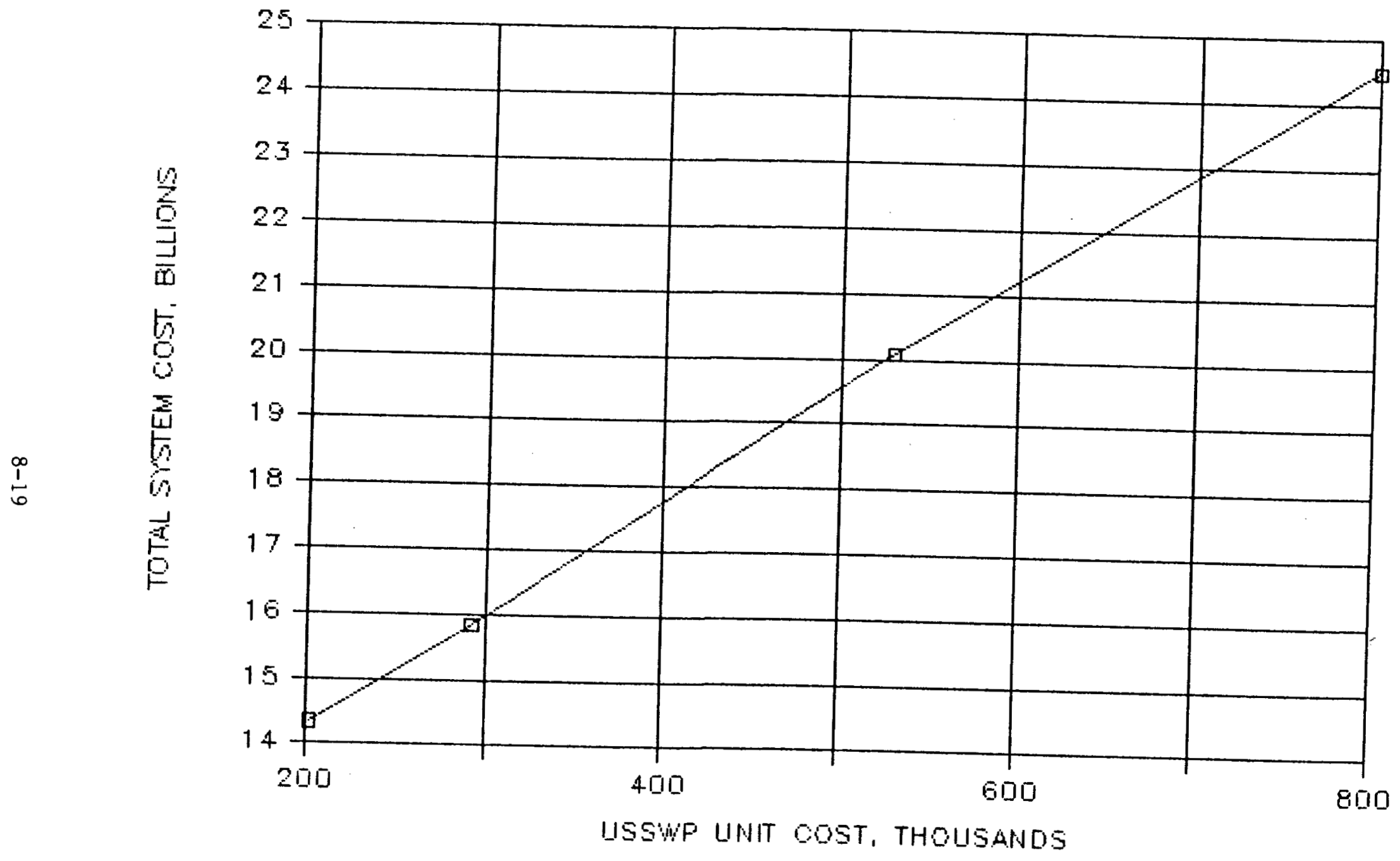

Fig. 8.5-1. Sensitivity of USSWP unit cost 
4. Regarding emplacement packaging and repository costs, it was not possible to separate out the capital and operating costs of removing the bolted lid on the WSSWP and replacing it with a welded lid. In the universal canister case, approximately half of the emplacement packaging cost is for the package components, leaving the balance, $\$ 1.5$ billion, for facilities and labor. A similar cost should be expected for the USSWP.

\subsubsection{MRS Cost Estimate}

The Westinghouse cost estimates for the MRS facility were compared with three other MRS cost estimates available from the PRDA study; the NUS estimate (Ref. 8-7), the Johnson Associates (JAI) estimate (Ref. 8-8), and the GA estimate (Ref. 8-3). The results of this comparison are discussed below.

8.5.2.1. Operating Costs. A comparison of MRS operating costs is shown in Fig. 8.5-2. All costs are shown in 1985 dollars. The costs for storage modules were removed from those estimates which had included them in the operating costs (e.g., the NUS and the GA estimates) so that all estimates would be done to the same criteria.

Some major points which can be made from this comparison are the following :

1. The NUS estimate is much higher than the other three estimates. It is $70 \%$ higher than the next highest figure (from JAI), and it is almost five times as high as the Westinghouse estimate.

2. The GA and JAI cost estimates have similar profiles from 2003 on. Only the front end of these curves vary significantly in shape. 


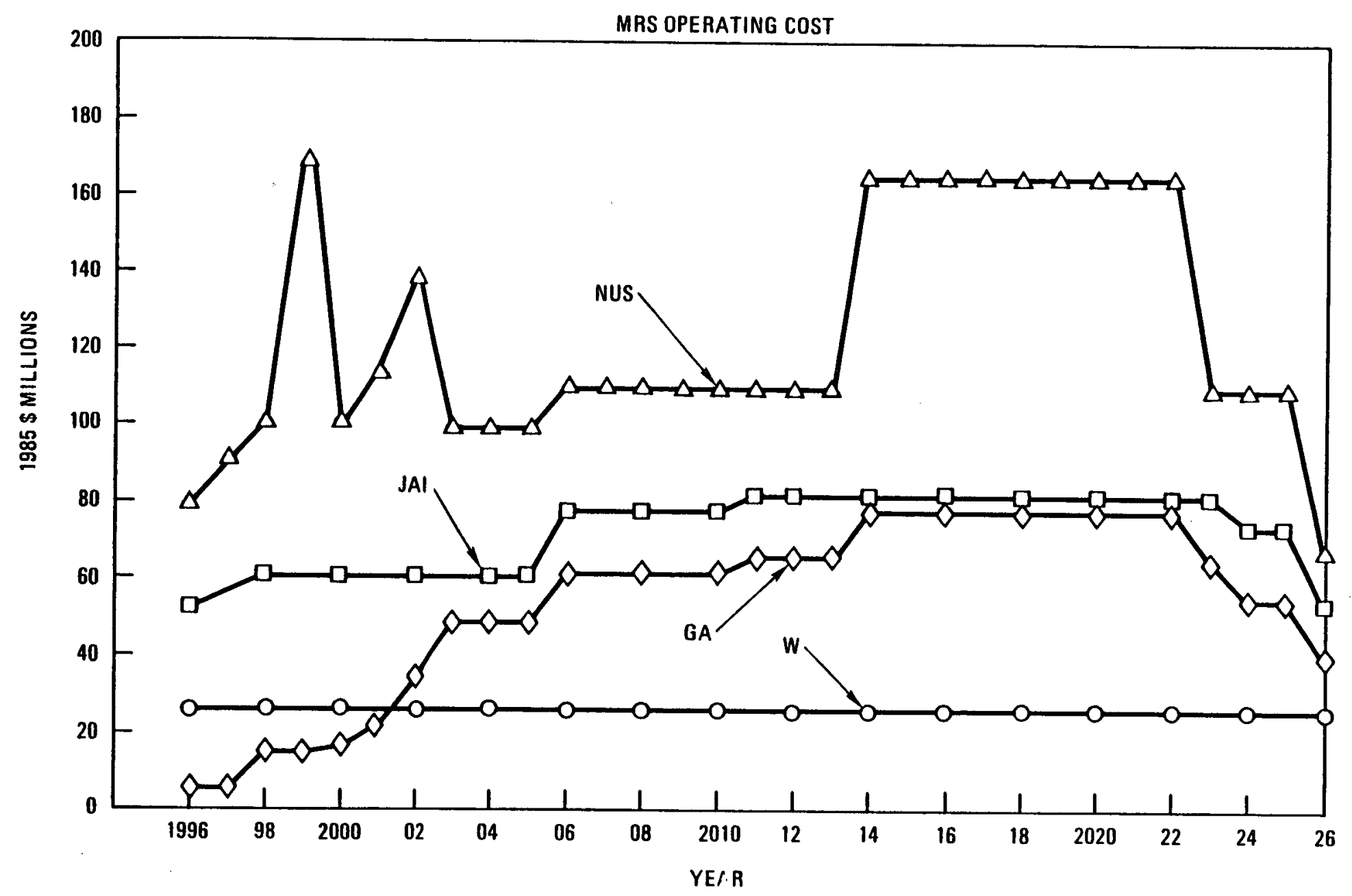

Fig. 8.5-2. MRS operating cost comparisons 
3. The Westinghouse cost estimate is much lower than the other three estimates. The Westinghouse curve is less than half of the next lowest curve examined (from GA).

4. The Westinghouse estimate is very flat throughout the time period examined. The cost estimate appears to be independent of the amount of material handled by the MRS. The remaining three estimates very with the amount of spent fuel handled by the MRS.

Compared with the other three MRS operating cost estimates, the Westinghouse estimate appears to be very unconservative in nature, and it is unresponsive to differences in operating level in the MRS.

\subsubsection{Capital Costs. The MRS capital cost comparison is listed in} Table 8.5-2 and illustrated in Fig. 8.5-3. Some obvious points from this comparison are listed below:

1. The NUS cost estimate is again higher than the other three. The NUS estimate is about 2.4 times higher than the Westinghouse estimate.

2. The JAI estimate includes $\$ 205$ mfllion in the 2000 to 2005 time period for expansion of their original facility. None of the other estimates has a similar breakout. Comparing totals, the JAI and NUS estimates are similar in magnitude.

3. The GA and Westinghouse cost curves have similar shapes throughout the period examined. The GA costs are about $22 \%$ greater than the Westinghouse estimates. 
TABLE 8.5-2

MRS CAPITAL COST

(1985 \$ Millions)

\begin{tabular}{|c|c|c|c|c|}
\hline Year & $\begin{array}{c}\text { Westinghouse } \\
\text { (Case } 12 \text { ) }\end{array}$ & NUS ${ }^{(b)}$ & $\mathrm{JAI}^{(\mathrm{c})}$ & $\mathrm{GA}^{(\mathrm{d})}$ \\
\hline 1990 & 30.47 & 36.25 & 21.67 & 33.30 \\
\hline 1991 & 30.47 & 108.74 & 65.02 & 40.87 \\
\hline 1992 & 60.95 & 144.99 & 86.69 & 74.16 \\
\hline 1993 & 60.95 & 181.25 & 102.61 & 75.68 \\
\hline 1994 & 60.95 & 181.25 & 113.91 & 76.44 \\
\hline 1995 & 60.95 & 72.49 & 79.26 & 70.38 \\
\hline \multirow[t]{2}{*}{ After } & - & -- & 205.21 & -- \\
\hline & 304.7 & 725.0 & 674.4 & 370.8 \\
\hline
\end{tabular}
(a) Reference 8-1, Table E-13.
(b) Reference 8-7, Table 6-54, escalated to $1985 \$$.
(c) Reference 8-8, Table 5-8, escalated to 1985 .
(d) Reference 8-3, Table 6-21. 


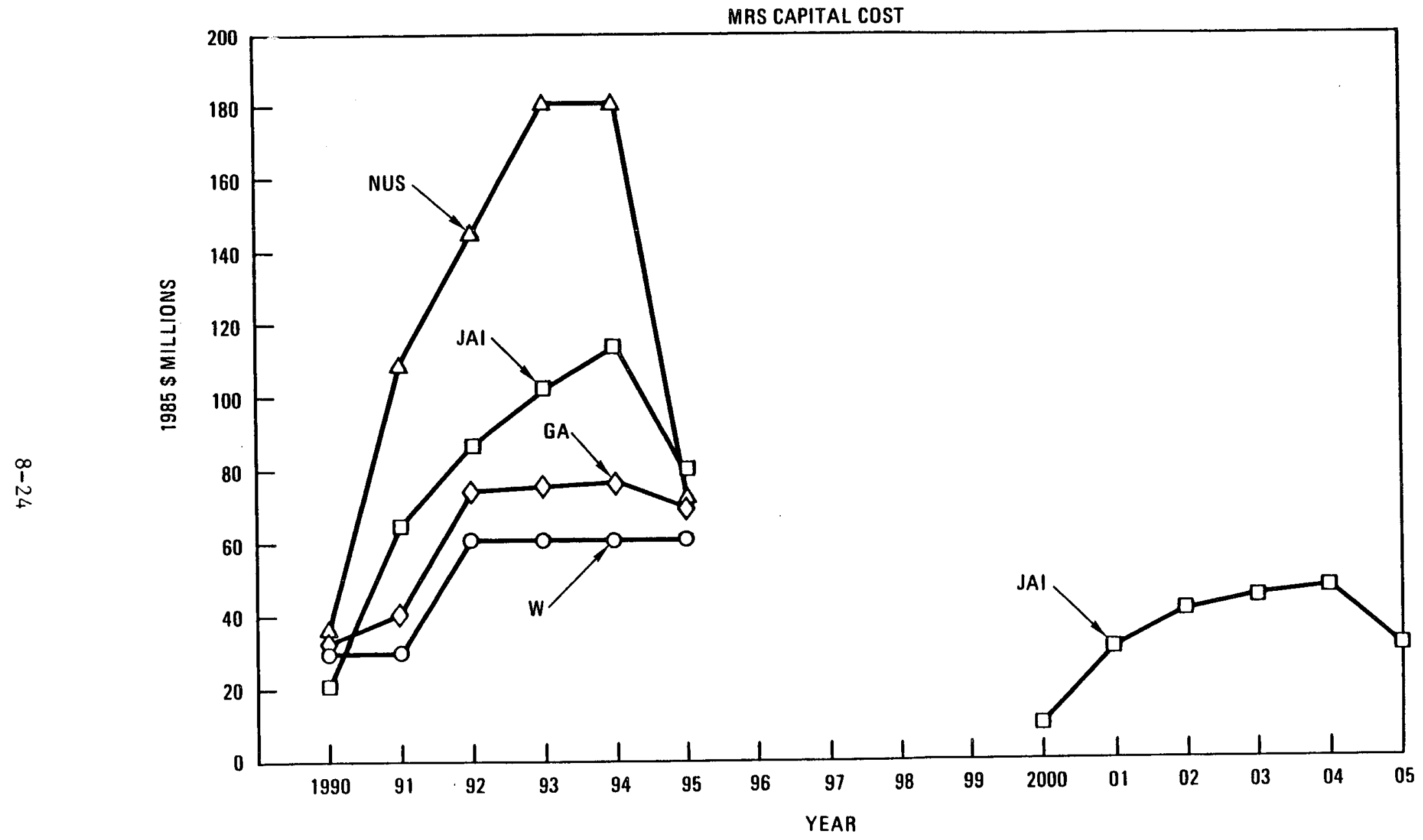

Fig. 8.5-3. MRS capital cost comparisons 


\subsection{REFERENCES}

8-1. "Phase 1 Study of Metallic Cask Systems for Spent Fuel Management From Reactor to Repository." Westinghouse Electric Corporation Report No. WTSD-TML-085 Draft, September 1985.

8-2. Weston, R. F., "Assumptions for Analyses Responding to the Program Research and Development Announcement 9PRDA for Nuclear Waste Packaging and Handling Design Initiatives," March 6, 1985.

8-3. "Commercial Radioactive Waste Management System Feasibility with the Untversal Canister Concept," GA Report, July 1985.

8-4. Bolmgren, C., Westinghouse, private communication with R. Morissette, GA, September 25, 1985, and with R. Lane, GA, October 15, 1985.

8-5. Smith, R., PNL, private communication with R. Morissette, GA, September 26, 1985. This is the design used by PNL for concrete storage casks, but it is not a regulatory requirement.

8-6. "Design Criteria for an Independent Spent Fuel Storage Installation (Dry Storage Type)," ANSI/ANS-57.9, 1984.

8-7. "An Assessment of the Use of Half-Square Cans on the Management of Spent Fue1," NUS Corporation Report NUS-4724, July 1985.

8-8. "Assessment of the Use of a Multi-Purpose and Centralized Facility for the Disassembly and Packaging of Spent Nuclear Fuel to Support the Various Segments of the DOE Waste Management System," E. R. Johnson Associates, Inc., Report JAI-254, May 1985. 